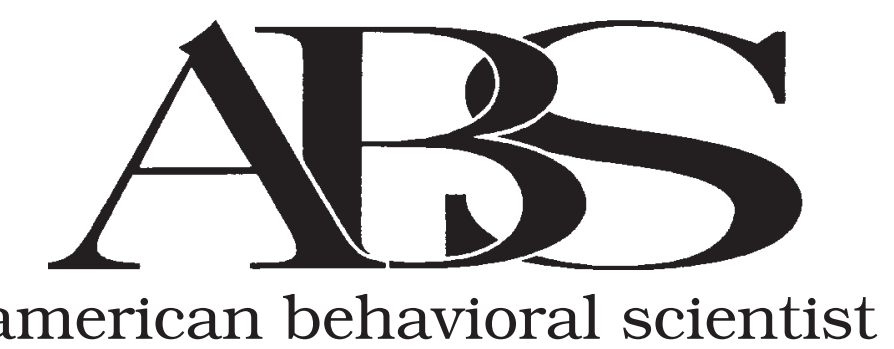

Volume 45, Number 4

December 2001

This issue is devoted to

HATE CRIMES AND ETHNIC CONFLICT:

A COMPARATIVE PERSPECTIVE

Edited by: JACK LEVIN

GORDANA RABRENOVIC

Northeastern University

\title{
CONTENTS
}

The Authors

Hate Crimes and Ethnic Conflict: An Introduction

JACK LEVIN and GORDANA RABRENOVIC

The Persecution of Gypsies in Europe

MARGARET BREARLEY

Aggressive Youth Cultures and Hate Crime:

Skinheads and Xenophobic Youth in Germany

MEREDITH W. WATTS

600

The International Commission of Inquiry (Rwanda):

Lessons and Observations From the Field

ERIC G. BERMAN

Hate Crimes Hurt More

PAUL IGANSKI

626

Ethno-National Conflict and Hate Crime

ROGER MAC GINTY

639

Renaming Violence

DEBRA RENEE KAUFMAN

The Birth and Maturation of Hate Crime Policy in the United States

RYKEN GRATTET and VALERIE JENNESS

Consequences for Victims:

A Comparison of Bias- and Non-Bias-Motivated Assaults

JACK MCDEVITT, JENNIFER BALBONI,

LUIS GARCIA, and JOANN GU

Extremism and the Constitution:

How America's Legal Evolution Affects the Response

to Extremism

BRIAN LEVIN 


\section{INTERNATIONAL EDITORIAL ADVISORY BOARD}

MAX H. BAZERMAN, Northwestern University

MARTIN BULMER, University of Surrey

KAY DEAUX, City University of New York

PAUL DiMAGGIO, Princeton University

DANIEL DRUCKMAN, George Mason University

TED ROBERT GURR, University of Maryland

ROM HARRÉ, University of Oxford

MARCEL LAFOLLETTE, The George Washington University

HENRY LEVIN, Columbia University

SEYMOUR MARTIN LIPSET, George Mason University

PETER LYMAN, University of California, Berkeley

DAVID LYON, Queen's University

GARY MARKS, University of North Carolina at Chapel Hill

JOSEPH E. McGRATH, University of Illinois, Urbana-Champaign

LINDA L. PUTNAM, Texas A\&M University

RICHARD SCHULZ, University of Pittsburgh

NEIL J. SMELSER, Center for Advanced Study in the Behavioral Sciences

MARK SNYDER, University of Minnesota

BARRIE THORNE, University of California, Berkeley

WILLIAM G. TIERNEY, University of Southern California

CHARLES TILLY, Columbia University

CAROL H. WEISS, Harvard University

JAMES YOUNISS, Catholic University of America

VIVIANA ZELIZER, Princeton University

For Sage Publications:

Laura Lawrie, Managing Editor

Sara Miller McCune, Executive Editor

Corina Villeda, Designer

Jason Dean, Production Editor

Rebecca Lucca, Copy Editor

AMERICAN BEHAVIORAL SCIENTIST (ISSN 0002-7642; ISBN 7619-1702-0) is published monthly by Sage Publications, 2455 Teller Road, Thousand Oaks, CA 91320; telephone (800) 818-SAGE (7243) and (805) 499-0721; fax/order line (805) 499-0871; e-mail order@sagepub.com; http://www.sagepub.com. Copyright @ 2001 by Sage Publications. All rights reserved. No portion of the contents may be reproduced in any form without written permission of the publisher.

Subscriptions: Annual subscription rates for institutions and individuals are based on the current frequency. Prices quoted are in U.S. dollars and are subject to change without notice. Canadian subscribers add 7\% GST (and HST as appropriate). Outside U.S. subscription rates include shipping via air-speeded delivery. Institutions: $\$ 865$ (within the U.S.) / $\$ 913$ (outside the U.S.) / single issue: $\$ 84$ (worldwide). Individuals: $\$ 130$ (within the U.S.) / $\$ 178$ (outside the U.S.) / single issue: $\$ 19$ (worldwide). Canadian subscribers must add $7 \%$ GST. Noninstitutional orders must be paid by personal check, VISA, or MasterCard.

Periodicals postage paid at Thousand Oaks, California, and additional mailing offices.

This journal is abstracted or indexed in Academic Index, Automatic Subject Citation Alert, Communication Abstracts, Current Contents/Social and Behavioral Sciences, Documentation in Public Administration, Educational Administration Abstracts, Ekistic Index, Family Resources Database, General Periodicals Index, Human Resources Abstracts, Linguistics and Language Behavior Abstracts, PsycLit, Research Alert, Sage Family Studies Abstracts, Social Planning/Policy \& Development Abstracts, Sage Urban Studies Abstracts, Socia Sciences Citation Index, Social Sciences Index, Social SciSearch, Sociological Abstracts, SRM-Bulletin: Abstracts \& Bibliographic References on Social Research Methodology, and United States Political Science Documents and is available on microfilm from University Microfilms, Ann Arbor, Michigan.

Back Issues: Information about availability and prices of back issues may be obtained from the publisher's order department (address below). Single-issue orders for 5 or more copies will receive a special adoption discount. Contact the order department for details. Write to the London office for sterling prices.

Inquiries: All subscription inquiries, orders, and renewals with ship-to addresses in North America, South America, and Canada must be addressed to Sage Publications, 2455 Teller Road, Thousand Oaks, CA 91320, U.S.A.; telephone (800) 818-SAGE (7243) and (805) 499-0721; fax (805) 499-0871; e-mail order@ sagepub.com; http://www.sagepub.com. Al subscription inquiries, orders, and renewals with ship-to addresses in the U.K., Europe, the Middle East, and Africa must be addressed to Sage Publications Ltd, 6 Bonhill Street, London EC2A 4PU, England; telephone +44 (0)20 7374-0645; fax +44 (020) 7374-8741. All subscription inquiries, orders, and renewals with ship-to addresses in India and South Asia must be addressed to Sage Publications Private Ltd, P.O. Box 4215, New Delhi 110 048, India; telephone (91-11) 641-9884; fax (91-11) 647-2426. Address all permissions requests to the Thousand Oaks office.

Authorization to photocopy items for internal or personal use, or the internal or personal use of specific clients, is granted by Sage Publications, for libraries and other users registered with the Copyright Clearance Center (CCC) Transactional Reporting Service, provided that the base fee of $50 \notin$ per copy, plus $10 \notin$ per copy page, is paid directly to CCC, 21 Congress St., Salem, MA 01970. 0002-7642/2001 \$.50+.10

Advertising: Current rates and specifications may be obtained by writing to the Advertising Manager at the Thousand Oaks office (address above).

Claims: Claims for undelivered copies must be made no later than six months following month of publication. The publisher will supply missing copies when losses have been sustained in transit and when the reserve stock will permit.

Change of Address: Six weeks' advance notice must be given when notifying of change of address. Please send the old address label along with the new address to ensure proper identification. Please specify name of journal. POSTMASTER: Send address changes to American Behavioral Scientist, c/o Sage Publications, 2455 Teller Road, Thousand Oaks, CA 91320.

Printed on acid-free paper 


\section{The Authors}

JENNIFER BALBONI is a senior research associate at the Center for Criminal Justice Policy Research and a doctoral student in the Law, Policy, and Society Program at Northeastern University.

ERIC G. BERMAN is currently an independent consultant based in Arlington, Massachusetts, having previously worked for the United Nations in Cambodia, Geneva, Nairobi, and New York. He has published widely on UN and security issues, including Peacekeeping in Africa: Capabilities and Culpabilities (with Katie E. Sams) and, most recently, Re-Armament in Sierra Leone: One Year After the Lome Peace Agreement.

MARGARET BREARLEY is currently an advisor on the Holocaust to the Archbishops' Council of the Church of England. She was formerly a university lecturer in medieval and Renaissance German literature and history of ideas (Birmingham); a senior fellow at the Centre for Judaism and Jewish-Christian Relations at Selly Oak Colleges, West Midlands; and a research fellow at the Institute of Jewish Affairs, London. Her publications include The Roma/ Gypsies: A Persecuted People (1995, London: IJA).

LUIS GARCIA is an assistant professor of sociology and director of the Criminal Justice Research Center at Suffolk University in Boston. He previously served as director of research and evaluation for the Boston Police Department.

RYKEN GRATTET is an associate professor of sociology at the University of California, Davis. His published work includes studies of imprisonment trends, the development of industrial accident laws and worker's compensation systems, and the legislative, judicial, and enforcement aspects of hate crime laws. $\mathrm{He}$ is the author of Making Hate a Crime: From Social Movement to Law Enforcement (with Valerie Jenness, 2001). His articles have appeared in the American Sociological Review, Law \& Society Review, Social Science History, the Journal of Criminal Law and Criminology, and Sociological Perspectives.

JOANN GU is the principal research analyst at the Boston Police Department, Office of Research and Evaluation.

PAUL IGANSKI is a lecturer in sociology and criminology at the University of Essex, England, and a civil society fellow at the Institute for Jewish Policy Research. The research for his article was carried out while he was a visiting scholar at the Brudnick Center on Violence and Conflict at Northeastern University, Boston. 
VALERIE JENNESS is chair of the Department of Criminology, Law and Society and an associate professor in the Department of Criminology, Law and Society and in the Department of Sociology at the University of California, Irvine. Her research focuses on the links between deviance and social control (especially law), gender, and social change (especially social movements). She is the author of three books, Making Hate a Crime: From Social Movement to Law Enforcement Practice (2001), Hate Crimes: New Social Movements and the Politics of Violence (1997), and Making It Work: The Prostitutes' Rights Movement in Perspective (1993), as well as numerous articles on the politics of prostitution, AIDS and civil liberties, hate crimes and hate crime law, and the gay/lesbian movement and the women's movement in the United States. Her work has been recognized with awards from the Gustavus Myers Center for the Study of Bigotry and Human Rights in North America, the Society for the Study of Social Problems, the Pacific Sociological Association, and the University of California; translated and reprinted in Japanese and German; presented at an array of professional conferences and universities, as well as to the U.S. Congress and the National Academy of Sciences; and funded by National Academy of Sciences, the National Science Foundation, the California Policy Research Center, the California Department of Mental Health, the University of California, and Washington State University.

DEBRA RENEE KAUFMAN is currently the director of Jewish Studies, a Matthews Distinguished Professor, and a professor of sociology at Northeastern University. Her most recent edited volume is Women and the Holocaust, and she was a special guest editor for Contemporary Jewry (1996). Her book Rachel's Daughters, about newly orthodox Jewish women, was nominated for three book awards. Her current research on Jewish identity among 20- to 30-year-olds was completed when she was a visiting scholar at Oxford University at the Centre for Hebrew and Jewish Studies. She continues to publish articles and chapters in the area of gender and identity politics as well as feminist theory and methodology.

BRIAN LEVIN, civil rights attorney and criminologist, is a professor of criminal justice and director of the Center for the Study of Hate \& Extremism (www.fighthate.org) at California State University, San Bernardino, where he specializes in analysis of hate crime terrorism and legal issues. Previously, Professor Levin served as associate director-legal affairs of the Southern Poverty Law Center's Klanwatch/Militia Task Force in Montgomery, Alabama, and as a New York City police officer. A graduate of Stanford Law School, he is the author or coauthor of various books, scholarly articles, training manuals, and studies on extremism and hate crime. Professor Levin has testified before Congress and is a court-certified expert on hate and extremism in the United States and England.

JACK LEVIN is the Brudnick Professor of Sociology and Criminology at Northeastern University, where he directs its Brudnick Center on Violence and 
Conflict. He has written a number of books on hate and violence including The Functions of Prejudice (1982), Hate Crimes: The Rising Tide of Bigotry and Bloodshed (1993), and The Violence of Hate: Confronting Racism, Anti-Semitism, and Other Forms of Bigotry (2001).

ROGER MAC GINTY is a lecturer at the Postwar Reconstruction and Development Unit, Department of Politics, University of York, United Kingdom. He has published extensively on peace processes and issues of ethno-national conflict. His book, The Management of Peace Processes (edited with John Darby) was published by Macmillan in 2000.

JACK MCDEVITT is an associate dean and director of the Center for Criminal Justice Policy Research at Northeastern University. He has worked in the area of hate crime research for nearly 15 years and has testified before the U.S. Congress on multiple occasions regarding the issue of hate crime.

GORDANA RABRENOVIC is an associate professor of sociology and education and associate director of the Brudnick Center on Violence and Conflict at Northeastern University. She specializes in social analysis in the area of community studies, education institutions, and intergroup conflict and violence. Her publications include "Women and Collective Action in Urban Neighborhoods," "The Dissolution of Yugoslavia: Ethnicity, Nationalism, and Exclusionary Communities," "From Consumers to Co-Producers: Charter Schools and Education Reform in Massachusetts," and "Spreading the Wealth: Economic Partnership and Community Development." She is also author of the book Community Builders: A Tale of Neighborhood Mobilization in Two Cities (1996) and coeditor of the book Community Politics and Policy (1999).

MEREDITH W. WATTS is a professor of political science at the University of Wisconsin-Milwaukee. His most recent books include Xenophobia in United Germany (1997) and the edited volume Cross-Cultural Perspectives on Youth and Violence (1998). Recent work has also included research on ethnocentrism and democratic values among Japanese youth and a current study of community-based human rights organizations. 


\title{
Hate Crimes and Ethnic Conflict
}

\author{
An Introduction
}

JACK LEVIN

GORDANA RABRENOVIC

Burdick Center on Violence and Conflict, Northeastern University

This issue of American Behavioral Scientist includes articles contributed by many of the leading figures in hate crime research from sociology, law, political science, and criminal justice who have investigated the problem of bias and violence in the United States and around the world. Our comparative perspective therefore encompasses a broad range of conflicts and countries including Gypsies in Europe, skinhead violence in Germany, civil war in Northern Ireland and Yugoslavia, genocide in Rwanda, and hate crimes in the United States.

In November 1998, the Brudnick Center on Violence and Conflict at Northeastern University sponsored an International Conference on Hate Crimes, whose participants came from a number of different countries including Northern Ireland, England, Hungary, Germany, and the United States. The participants were subsequently asked to write papers addressing certain themes about hate crimes and ethnic conflict that emerged during the conference proceedings.

A guiding theme for this issue of $A B S$ is the manner in which hate crimes can escalate into widespread intergroup conflict. We address this relationship, first, by emphasizing the distinction between individual-level variables involved in hate crimes and the sociocultural bases for ethnic conflict and, second, by suggesting how individual hate crimes and large-scale ethnic violence are related. In the process, we also summarize the suggestions for reducing hate and conflict—psychological, social, and legal—discussed in the articles prepared for this issue.

\section{HATE CRIMES AND ETHNIC VIOLENCE IN THE UNITED STATES}

Behavioral scientists have long recognized the individual as a "silent partner" in any process of social change (Allport, 1954). Important structural alterations

AMERICAN BEHAVIORAL SCIENTIST, Vol. 45 No. 4, December 2001 574-587

(C) 2001 Sage Publications 
are aided, if not made possible, by the presence of a sufficient number of individuals in a society who are willing to accept or at least not actively oppose significant change. In addition to coercive policies, social structure depends for its maintenance and modification on the conformity and obedience of the members of society. Without their personal support for change, maintenance of the status quo is more likely; in the absence of support for the status quo, terrorism, civil war, and revolution become more probable.

Less obvious, however, is the fact that not all structural change takes the form of pervasive social phenomena. More typically, what begins as individual action is transformed into large-scale social process. The behavior of merely a few members of society has been known to provoke massive modifications in social, economic, and political relations.

In the relationship between hate crimes and ethnic conflict, we see clearly the important contribution made by individual conduct to the development of group action. When they are allowed to go unchecked and unpunished, incidents of hate and bigotry can easily become part of a vicious cycle of violence that spirals out of control and ultimately escalates into pervasive intergroup hostilities.

This relationship is most likely to occur in hate crimes motivated by vengeance, where the commission of an offense against a group is regarded as so egregious, so sinister and unjustified, that it inspires "the other side" to get even with the perpetrator by indiscriminately targeting for revenge any member of the perpetrator's group. The vicious cycle of vengeance may not be broken until formal authority has intervened in an effective manner or until all-out warfare has occurred. Moreover, hate crimes that go unchallenged implicitly send a message of support and encouragement to those who would perpetrate violence in the future.

An appropriate example of the escalation from hate crimes to ethnic conflict can be found in the Crown Heights section of New York City, which has long had a history of hostility between its Black and Jewish neighbors. In August 1991, a 7-year-old Black child, Gavin Cato, was killed as a result of an accident involving an Orthodox Jewish motorist, whose car had jumped the curb. In retaliation, Black youngsters raced through the streets of Crown Heights, shouting anti-Semitic epithets and threats. Shortly thereafter, a 29 -year-old rabbinical student from Australia who just happened to be in the wrong place at the wrong time and was totally unconnected to the accident was stabbed to death. For the better part of a week, Blacks and Jews exchanged insults, broke windows in homes and cars, and threw bottles and rocks at one another. Before the melee finally came to an end, dozens more were injured (Levin \& McDevitt, 1993).

Intergroup incidents do not always precipitate the sort of warfare associated with Crown Heights and, in certain cases, may even facilitate reconciliation and cooperation between groups. In sharp contrast to the massive outbreak of violence in Crown Heights, community responses were far more muted and reasonable in the aftermath of a vicious 1998 racial incident in the city of Jasper, Texas. James Byrd, a Black resident of this east Texas community of some 9,000, was 
dragged to his death down a rocky country road behind a pickup truck driven by three White supremacists. The perpetrators, who had met in prison and were linked with the Ku Klux Klan, seemed to be sending a message to every Black person in town: Namely, get out of town before the same thing happens to you!

Rather than divide the community on racial grounds, however, the murder of James Byrd actually served to bring the Black and White residents of Jasper together. In the aftermath of the slaying, townspeople reported going out of their way to cross racial lines in greeting residents and feeling a new street-level friendliness toward members of the other race.

Following the trial and conviction of the first defendant, his father phoned the local radio station not to hurl racial accusations but to urge townspeople to "fill the void made by his mess with love and tolerance" (Shlachter, 1999).

Just as in Crown Heights, Blacks and Whites in Jasper had not always been sympathetic toward one another. One issue that had long symbolized the community's struggle with race relations was the town's cemetery, where a fence down the middle separated Whites buried on one side from Blacks buried on the other. After Byrd's murder, however, the town came to an agreement to integrate its cemetery. Many residents of Jasper, Black and White, joined together to pull out the posts and tear down the fence (Labalme, 1999, p. B1).

In Crown Heights, mistrust and suspicion were palpable on both sides of the racial ledger. Many Black residents were convinced that the motorist who hit the Black child would get off scot-free due to the perception that Jewish residents enjoyed special treatment from city officials. At the same time, Jewish residents of Crown Heights were certain that the Black mayor of New York City would do little if anything to bring the murderer of the Australian rabbinical student to justice.

By contrast, the political leaders in Jasper had strong credibility among both its Black and its White residents. Local government had long been racially integrated. Black residents, who composed some $45 \%$ of the town's population, occupied the position of mayor, two of the five city council positions, and the directorship of the Deep East Texas Council of Governments. In addition, school principals and the administrator of the largest hospital were Black.

Jasper's White sheriff went out of his way to inspire confidence among Black residents in the aftermath of Byrd's slaying. Within 24 hours, he had arrested two suspects and then immediately requested the assistance of the FBI. Moreover, Jasper's local 6,000-watt radio station kept residents informed in an even-handed way about developments related to the murder and the trials, ensuring that racially dangerous rumors and anxieties never had an opportunity to spread (Shlachter, 1999).

Another important difference between the racial incidents in Crown Heights and Jasper, Texas, involves their residents' degree of community identification. In Crown Heights, identification seemed primarily to be based on race ("the Black community"), religion ("the Jewish community"), or a shared sense of being part of the much larger New York City population. In this regard, the 
Crown Heights neighborhood was almost irrelevant. By contrast, Jasper, Texas, represented a primary source of community identity for Black and White residents alike. Even extremists on both sides of the racial ledger were genuinely embarrassed by the cruelty and sadism of James Byrd's murder. They seemed to unite across racial lines against the very strong stigma imposed on their community by members of the outside world.

\section{ESCALATION OF HATE CRIMES}

Behavioral scientists have long known that intergroup hostility escalates as a result of increasing intergroup contact, especially in the form of competition for scarce resources (Sherif \& Sherif, 1961). Research conducted by The Chicago Reporter (Gordon \& Pardo, 1997) suggests that Chicago-area suburbs with growing minority populations have recently experienced increasing numbers of hate offenses against Blacks and Latinos. In many previously all-White suburban communities, minorities have reached a critical mass, causing White residents to feel threatened by the influx of newcomers. This seems to be the point at which hate crimes escalate.

Those who argue that hate crimes have increased over the past 20 years also note that intergroup competition has been on the rise (Olzak, Shanahan, \& McEneaney, 1996). Whether or not economically based, growing threats to the advantaged majority group since the early 1980s may have inspired a rising tide of hate incidents directed against members of challenging groups. Over the past two decades, there have been dramatic increases in interfaith and interrace dating and marriage; migration, especially from Latin America and Asia; newly integrated neighborhoods, schools, college dormitories, and workplaces; and gay men and lesbians coming out (and, in many cases, organizing on behalf of their shared interests).

Green, Strolovitch, and Wong (1997) have shown that hate crimes occur most frequently in "defended" White neighborhoods - that is, in predominantly White areas that have experienced an in-migration of minorities. Extending Green et al.'s concept of defended neighborhood to a broader range of perpetrators, victims, and situations, it appears that hate violence is likely to occur wherever the advantaged or protected status of a group is being threatened - on the block, in the office, or on campus. Under such conditions, offenders seek to reduce a perceived threat by attacking outsiders who have dared to challenge their "birthright." If the initial hate crime does not succeed in removing the threat, then perpetrators may decide to escalate their attacks until they have achieved their objective.

Meredith Watts shows that in Germany the targets of violence have remained relatively constant since 1990 . The majority of victims (60\%) are foreigners. The perpetrators, young males ages 16 to 30 , usually acting in groups, react 
"defensively" to structural changes, stress in employment markets, and a significant influx of people perceived as foreigners.

A different sort of escalation is possible in thrill hate crimes, wherein groups of youthful offenders - to gain some vague sense of their own importance and bragging rights with their friends - seek to victimize the members of a degraded group. They go out with their friends on a Saturday night, looking for the enemy to bash. Their sadistic treatment of victims represents an attempt to feel a sense of power and superiority (Levin \& McDevitt, 1993).

In thrill-motivated hate crimes, the teenagers or young adults who attack tend to be marginalized young people who may not be getting along at home with their parents and are not doing well at school with their peers. They are totally unsophisticated with respect to the ideology of hate but gain from their violence by feeling a sense of power and belonging that seemed out of their grasp when they behaved themselves and respected people who were different from them. The psychological basis for thrill hate crimes is emphasized in the tendency of perpetrators to adopt the symbols of power associated with organized hate groups. They wear the Nazi uniforms, the swastikas, the White power tattoos.

As hate crimes are transformed into intergroup violence, those youngsters who perpetrate thrill hate offenses can easily become the foot soldiers for a terrorist group or a revolutionary movement. According to Meredith Watts, the vast majority of German citizens who attacked immigrants and minorities in the 1990s after reunification were under the age of 20 - they were teenagers driven more by personal misery than by political ideology. In contrast to their counterparts operating during the 1980 s, fewer had ties to organized hate groups or were sophisticated with respect to Nazi ideology. Data from the United States show a similar trend.

In the United States, less than 5\% of all hate crimes are mission hate offenses committed by the members of organized hate groups who make a career of expressing their bigotry. Yet, the influence of the perpetrators of mission offenses is much greater than their small numbers might suggest. Most of the young people who commit thrill and defensive hate violence may not be connected to organized hate groups, but they are certainly inspired by (and sometimes trained by) hardened hatemongers. The large and rapidly growing number of hate Web sites has greatly expanded the influence of White supremacist groups who, with minimal economic and human resources, are now able to reach thousands of alienated youngsters searching for company.

\section{HATE CRIMES AND ETHNIC CONFLICT IN INTERNATIONAL PERSPECTIVE}

The most common basis for hate crimes is the animosity that develops between people based on their race, ethnicity, or religion. In times of economic instability, structural changes, or political turmoil, the members of the majority 
group often react to a real or perceived threat to their position in society by turning against the members of minority groups in their midst. Operating under a zero-sum definition of the situation (i.e., someone else's loss is viewed as a personal gain), they try to limit the minority's civil rights and access to their country's economic resources. The inability of the formal governing structures to protect the human rights of all residents and to address growing social inequalities becomes the root cause of many ethnic conflicts. In their extreme forms, such conflicts can lead to expelling and executing minority group members for the purpose of creating ethnically homogeneous societies.

Ethnic cleansing and civil war in the former Yugoslavia provide an appropriate example of how an escalation of ethnic conflict can be used to impose such an outcome. Post-Second World War Yugoslavia was built based on the ideal of an integrated and ethnically diverse society. However, economic and political crises of the late 1980s challenged this ideal to the extent that incidents of ethnic hatred that had been previously punishable by law were now officially ignored. An increasing number of such incidents reflected a weakening of the social order and of the ideology of ethnic coexistence. The lack of formal response by the police and the courts further undermined the social order by decreasing the average citizen's trust in the legal system as well as the belief that justice would prevail. Furthermore, the inability of the existing party leaders and the federal government to come up with solutions for the troubled Yugoslavian economy created a power vacuum. By offering solutions to the country's problems, ethnic leaders emerged who promoted intergroup fears and hatred. Minorities were identified as a threat to the stability and safety of the majority group. Ethnic conflict thus developed as a part of the process of increased discrimination against minority residents.

Multiethnic societies are faced with the problem of how to balance human rights with ethnic rights. Human rights are often defined as individual, citizenship rights that theoretically apply to each and every member of society, whereas ethnic rights refer to the special prerogatives granted to a minority group to address its particular needs. Increasing numbers of governments are paying attention to handling intergroup relations by recognizing minority rights and by making special provisions for them. International organizations such as the Organization for Security and Cooperation in Europe and the Council of Europe are also actively promoting standards that enhance minority rights such as to "prohibit forced assimilation and population transfers, endorse autonomy for minorities within existing states, and acknowledge that minority claims are legitimate subjects of international discussion at both U.N. [United Nations] and European regional organizations" (Gurr, 2000, p. 55).

Ethnic conflict often has its roots in the inability of government to first legitimate and then recognize and protect minority rights. Yugoslavia, again, is a good example. In postcommunist Yugoslavia, members of the Albanian minority group lost most of their ethnic rights when Slobodan Milosevic came into power. To consolidate his absolute power and control, Milosevic exploited 
Serbian fears and grievances against Albanians. At the same time, there is also evidence that the Serbian population might-under different circumstanceshave supported a more peaceful solution to the problem of majority-minority relations.

In 1996, the Helsinki Committee conducted a public opinion poll of 500 Serbian respondents on their views of human rights for the ethnic minorities in their country. The question posed was, Should Serbs in Serbia have more rights than members of other ethnic groups? The majority of Serbs (54\%) responded by rejecting the unequal treatment of other ethnic groups. More troubling for achieving resolution of ethnic conflict minorities, however, was the finding that $40 \%$ of the respondents thought that the members of the majority group should be granted more rights than their minority counterparts. Further results of the poll showed that Serbs were more willing to give minorities some group rights, such as the right to practice their own religion, conduct cultural manifestations, publish their own newspapers, and even have education institutions in their own language. But, the same set of respondents was also against giving minority residents the right to use their own language in formal institutions and local government, even in the regions where they were in the majority, and in political organizations. Serbian respondents saw such rights as potentially destabilizing for the nation as a whole.

However, most respondents (72.6\%) thought that increasing the standard of living for all residents would decrease tension among ethnic groups. Also, more than a third (37\%) thought that the ethnic conflict might be solved by giving minority groups all of the rights enjoyed by other citizens. Therefore, we can see that a large number of respondents provided support for policies that promote accommodation instead of prolonged conflict. At the same time, $29 \%$ of the respondents also thought that the solution to ethnic conflict could be secured by encouraging members of the minority group in a peaceful way, to leave the country, and $8 \%$ supported the forceful resettlement of minority residents. These results support the argument for an early intervention: The longer the tension between democratic and antidemocratic tendencies is allowed to go unresolved, the less likely is any chance to come up with a peaceful and democratic solution.

How does a country move from peaceful coexistence to ethnic war? Within the Yugoslavian context, the mass media played an important role in promoting ethnic hatred in general and the ethnic rhetoric of nationalistic parties in particular. Although opposition newspapers and radio stations existed, they were no match for the well supported official media. National television stations, for example, broadcast images of suffering members of their own ethnic group, without mentioning the suffering of others. Newspapers published the stories that documented abuses of "their" people at the hands of others, without referring to the abuses to others tolerated or promoted in their own states. Also completely missing from the ethnic rhetoric were examples of cooperation and peaceful coexistence among different ethnic groups in the country. 
Margaret Brearley's analysis of the persecution of Gypsies in Europe brings together several of the themes we have mentioned here. The worsening of economic conditions and political instability in countries of central and eastern Europe where the Roma are a minority group has helped to turn this minority into a national scapegoat, explaining all of society's ills. Moreover, renewed nationalistic ideologies have helped to channel the displaced hostility of a frustrated population toward this stigmatized ethnic group. Consequently, the Roma have faced increased discrimination by both national governments and local authorities in places where they reside. They are often victimized by a hostile media, widespread personal hatred, and violence perpetrated by lynch mobs, skinheads, and the police. In addition, when the Roma have sought to flee the danger, they have frequently been denied safe havens as refugees. Even international organizations often fail to step up and protect them, as the most recent example of continuous harassment and attacks against Roma in Kosovo shows.

The limitation of international organizations to resolve and prevent ethnic conflict is the topic of Eric Berman's article on Rwanda. As a member of the UN International Commission of Inquiry, he provides a firsthand account of the limits of this international body to intervene in ethnic conflict. He shows that although it was well aware of unfolding atrocities, the international community did little to stop them. Moreover, when external pressure was finally brought to bear, it was mostly too little too late. In his documentation of the work of the International Commission of Inquiry, Berman shows that without adequate funding and the political will to support UN resolutions, there is very little that this organization can do to prevent atrocities from occurring.

\section{POLITICIZING HATE CRIMES}

A recent article in Foreign Affairs argues that contrary to popular beliefs, there has been a sharp decline in new ethnic wars. Moreover, most such conflicts get resolved not through large-scale physical confrontation but by means of a political process involving accommodation and negotiation (Gurr, 2000, p. 52). It should be noted, in addition, that the success of strategies for the avoidance of warfare depends also on the ability of national governments and their legal systems to recognize hate crimes as precursors of worse things to come and early enough to develop strategies to address them.

In recognizing the political functions of hate crimes, we move our analysis from interpreting hate crimes as individual and personal conflicts to regarding them as political acts. Roger Mac Ginty's article provides evidence for this position by analyzing examples from deeply divided societies such as Northern Ireland, South Africa, and Israel/Palestine. He compares what he calls "ethno-national" conflicts with individual acts of hate crimes. Violent conflicts that develop in deeply divided societies, he argues, are carried out by paramilitary organizations. The level of violence in these conflicts varies in scale, 
complexity, intensity, longevity, the actors involved, and tactics used. However, most of these conflicts are characterized by low-level violence, which Mac Ginty argues is similar in form to hate crimes. Although particular violent incidents are part of a wider conflict, they are perceived by victims as though they constituted individual and isolated hate attacks exclusively against them.

Structural factors regulate the level and visibility of hate crimes. Ethno-national violence develops in cycles. Certain stages in a cycle of conflict are especially likely to provide opportunities for hate crimes to develop. What is more, the control of hate crimes in deeply divided societies is based on a high degree of ethnic segregation. Because residents live in sharply delineated areas, there is little daily contact between warring parties of a cooperative or friendly nature that might reduce the sanctioning of hate and bigotry.

Another important factor in controlling hate crimes is the paramilitary monopolization of conflict. Intergroup hostilities are frequently regulated by nonstate militant organizations, whose leaders do not regard hate crimes as the most efficient way for realizing their goals. Indeed, reliance on an unsystematically carried-out agenda of hate attacks could, from a paramilitary perspective, even be counterproductive because they can be interpreted as individual and personal rather than a part of political process.

Mac Ginty argues, however, that hate crimes increase during peace processes. Because a primary motivation for ethnic violence is to instill fear, there is often an intensification of the violence meant to exacerbate the fear of political change so long as the process of peace negotiations continues. Hate crimes then become part of a political strategy. They are carried out by individuals or groups of individuals rather than by paramilitary organizations. The timing of much of hate crime incidents is deliberate. It often coincides with major political developments. Mac Ginty warns us that an inflated governmental response to these isolated incidents may give those individuals and groups engaged in hate crimes the legitimacy they crave.

Thus, all hate crimes are potentially political. The key difference between hate crimes in the United States and ethnic violence carried out by paramilitary groups in deeply divided societies lies in the context in which the violence takes place and the manner in which the motivation for the violence is articulated.

Another interpretation of violence comes from Debra Kaufman's article. Her examination of violence, gender, and the Holocaust uses role analysis and sociocultural and structural level analyses to explain violent behavior. Gender role theory, she argues, helps us to empirically locate many of the issues neglected or simply unobserved in the study of war. Before we can sociologically understand violent behavior, we must learn how to identify it in all of its dimensions-when it begins, when it ends, where the geographic and time boundaries are, who are the perpetrators, and who are the victims. By showing that hate-motivated violence is multidimensional, Kaufman's analysis challenges the gender neutral treatment of Holocaust victims and further supports Mac Ginty's argument that hate crimes are politically motivated rather than 
merely an end in themselves, that is, hate for hate's sake. It also deepens our understanding of public and private spheres of life and expands what we mean by victims, survivors, and resisters.

\section{LEGAL INTERPRETATION OF HATE CRIMES}

The persistent question that proponents of hate crime laws face is whether we need to maintain hate crimes as a separate legal category. Although in the United States 41 states have hate crime statutes covering race and religion, the legitimacy of hate crimes as a legal category is still being contested. To understand these challenges, we need to understand the process under which hate crime laws have emerged. Grattet and Jenness's article examines the social processes that led to the development and institutionalization of hate crimes as a domain of public policy. To bring the issue of discriminatory violence into public consciousness, the authors argue, social movement organizations such as the Anti-Defamation League (ADL) and the Southern Poverty Law Center first had to construct the problem of hate-motivated violence. It was at this point in time that the politicians, the courts, and law enforcement officials had to get involved in the process of defining the policy parameters of hate crimes to investigate and prosecute them.

In 1981, the ADL drafted a model hate crimes law. Race-, religion-, and ethnicity-based violence were institutionalized as legitimate subjects for federal discrimination legislation. Over time, however, the concept of hate crimes was expanded to include gender, sexual orientation, and disability status. Based on 1999 federal hate crime statistics, there where 7,876 criminal incidents motivated by hate or bias, overall. Of these, 4,295 or $56.3 \%$ were based on the victim's race, 1,411 or $16.5 \%$ on religion, 1,317 or $16 \%$ on sexual orientation, and 829 or $10.9 \%$ on ethnicity (FBI, 1999). Based on FBI data, therefore, we see that sexual orientation may actually be outpacing ethnicity as an important source of hate crimes in the United States.

Grattet and Jenness also address some of the major criticisms of hate crime laws, such as the contention that hate crimes represent such a subjective and vague concept that trying to litigate in the hate crime area will inevitably lead to a waste of legal resources. The authors show instead that the ambiguity of the hate crime concept has diminished over time. In fact, Grattet and Jenness argue that it is the "newness" of the concept and not its inherent ambiguity that has created implementation problems.

Brian Levin, on the other hand, addresses another concern about hate crime laws, mainly whether they punish speech (intimidation and harassment) rather than conduct. Levin situates his analysis within a discussion of the First Amendment to the Constitution of the United States. The legal issues that he examines are the legal protection of speech and various types of associations, militias and gun rights, civil lawsuits against hate groups, hate crime laws, and the Internet. It 
is clear from Levin's analysis that the First Amendment plays a much larger role in framing America's legal response to hate than is the case in European countries where hate speech is unprotected by law.

\section{ARE HATE CRIMES DIFFERENT FROM ORDINARY CRIMES?}

The second most asked question about hate crimes involves whether they are actually separate and distinct from other criminal incidents. The proponents of hate crime legislation challenge the arguments put forward by critics of hate crime laws, mainly that the consequences of such offenses for their victims are essentially the same as the consequences of offenses not motivated by hate or bias. McDevitt et al. and Iganski provide strong empirical evidence for the argument that hate or bias crimes are actually more damaging to their victims, who tend to suffer greater trauma and more serious psychological effects.

McDevitt and his collaborators based their study on a survey of victims of both bias and nonbias aggravated assaults in the city of Boston. The authors compiled information about the psychological and behavioral impact of violent crime victimization based on a mail survey instrument. The findings of their study show that the victims of hate crimes reported significantly greater psychological consequences of their victimization experience, including a higher level of intrusive thoughts, feelings of lack of safety, nervousness, and depression, in comparison with other victims of assault.

Complementing McDevitt et al.'s quantitative analysis, Paul Iganski's article offers qualitative data on the same subject. Iganski addresses the question of the justification or logic of punishing the bias motivation underlying hate crimes when the law largely protects this type of speech. Bias crimes, argues Iganski, are qualitatively different from the same act lacking the same motivation. His research data come from in-depth interviews with "elite" informants, the individuals who were actively involved in policy debates and policy activity on hate crimes. Most of the respondents believed that hate crimes are distinct from similar offenses because of the greater harm they inflict on their victims. Because punishment is assigned based on harm, hate crime legislation does not infringe on an individual's rights of speech or freedom of thought.

The need to react more strongly to bias crime than to similar non-hate-motivated offenses is also defended by the argument that the punishment of a bias crime also sends a message to members of the offender's group. As one respondent in Iganski's study argued, by punishing bias crime more severely, the victim's group is sending back a message to the perpetrator's group that "we're not going to stand for this; you're going to suffer as we did" (p. 630). Therefore, the crime could not be ignored as an isolated incident.

Both McDevitt and his collaborators and Iganski argue that hate crimes are also more harmful to the social fabric of the society than comparable crimes 
without a bias motive. This is due to victim interchangeability. That is, victims are chosen strictly because of their membership in a particular group and not necessarily because of any prior actions they may have taken. Hate crimes also show a greater capacity for producing secondary victimization among the victim's family and community. And finally, hate crimes have the power to escalate from individual acts of violence to large-scale social conflict. Here again, we see a close connection between hate crimes and ethnic hostilities.

\section{RESPONDING TO HATE CRIMES AND ETHNIC VIOLENCE}

The articles in this issue show that the problems of hate crimes and ethnic violence are not easy to resolve. They require long-term commitment and support by individual citizens, national governments, and international organizations. Some promising signs to this end are discussed in Gurr's (2000) recent article in Foreign Affairs. The decline of ethnic conflict, he argues, can be attributed to several new developments. First, Gurr sees an increased willingness of governments of multiethnic societies to protect the collective rights of minority groups. Second, he argues there has been an increased democratization of many societies and growing presence of institutional means that allow minority groups to secure their rights and pursue their collective interests. Gurr's third reason for the decline of ethnic conflict involves the expanding use of the principle according to which disputes over self-determination are best settled not by physical force but by negotiation and mutual accommodation (p. 58).

There is a need for more studies to document these processes and to show how and under which conditions ethnic conflict gets resolved using peaceful means. How are we to explain, for example, why Bulgaria-notwithstanding its proximity to the former Yugoslavia, a potentially explosive ethnic mix, and an impoverished economy-represents the only country in the Balkans that has escaped serious internal conflict?

There is also the question of how to achieve postconflict reconciliation. For societies such as Rwanda and Yugoslavia that experience violent conflict, the process of reestablishing the norms of civil society, human rights, and legal environment is a difficult task. It will require the development of an independent judicial system, a constitution that will guarantee rights of minorities including their equal access to media, and the institutionalization of civil standards for engaging in public discourse. However, there will be no lasting peace among former enemies if they do not confront the past. Truth and reconciliation programs that are supported by grassroots and nongovernmental organizations (NGOs) in many former conflict areas are an important component of the healing process. Reconciliation is only possible when people know the truth, and their dignity as human beings is restored. 
The role of NGOs in rebuilding postwar societies is well documented. Such organizations have been involved in strengthening the fabric of civil society and in fostering social, economic, and cultural development. Mostly women-led, NGOs are especially important in this process because they have a track record of crossing ethnic boundaries and getting together the opposing groups around shared issues, such as community development, provision of local services, and peace work. The involvement of women in these organizations increases their economic and political role and leads to greater gender equality. This is important because societies that have greater gender equality are less likely to militarize again. The danger to women is, however, that in peace times women are often pushed back into their homes and out of the more public roles that they have assumed during the armed conflict.

And finally, because we live in a more connected world, the boundaries between national and international responsibilities are often blurred. As Meredith Watts shows, for example, the suppression of hate literature by one nation is not, in times of global electronic networks, a solution to the problem of ethnic conflict and hate. According to the Wiesenthal Center, there are currently more than 2,000 groups on the Internet that promote anti-Semitism or White supremacist messages. Similarly, Internet-based auction houses sell Ku Klux Klan and Nazi paraphernalia, and booksellers offer hate literature including The Turner Diaries and Mein Kampf (Guernsey, 2000, p. G1). National Web sites that reach an international audience are no match for any nation's policy of formal prohibition and restriction.

There has been some effort to regulate Internet content. Most recently, a judge in France ordered Yahoo, an Internet provider from the United States, to block access to Nazi material from its sites available to French citizens. This case opened for scrutiny a new area of legal discussion regarding the connection between freedom of speech and globalization. Some of the questions asked are, "How will the Internet coexist with different countries' standards of free expression? What, if anything, can or will countries do to block speech that they don't like?" (Kaplan, 2000). To this point, Internet providers have refused to monitor these hate sites or to take responsibility for their content. Some legal scholars think that this is the wrong strategy. For example, instead of focusing on Internet providers, argues Alan Davidson, a lawyer for the Center for Democracy and Technology, "the focus should be on the end user, so residents of France, for example, would be punished for gaining access to illegal material in their country" (Guernsey, 2000, p. G1). Internet providers, though, are willing to engage in discussions as to how to respond to hate content and to act on complaints by other organizations. This willingness shows that even here, the processes of negotiation and accommodation might represent an effective strategy.

The focus on hate speech on the Internet, however, obscures more dangerous developments in Europe. The increase of extremist groups such as racist skinheads in Germany and Le Pen's nativist constituency in France suggests the uneasiness of residents with the growing number of immigrants on their soil. 
Moreover, at the same time that the European Union is making many national borders absolute, there is also growing fear that individual countries will lose their national identities. In such a climate, anti-immigrant outbursts in the form of vicious hate attacks are becoming more frequent. Although they are, for the most part, still isolated incidents, they are increasingly troublesome. Many European countries still have a long way to go in terms of helping to integrate newcomers into their societies. An important first step might be to grant them easier access to citizenship.

\section{REFERENCES}

Allport, G. W. (1954). The nature of prejudice. Reading, MA: Addison-Wesley.

Federal Bureau of Investigation. (1999). Hate crime statistics. Washington, DC: Government Printing Office.

Gordon, D., \& Pardo, N. (1997, September). Hate crimes strike changing suburbs. The Chicago Reporter, p. 1.

Green, D. P., Strolovitch, D. Z., \& Wong, J. S. (1997, June 23). Defended neighborhoods, integration, and hate crime. Unpublished manuscript, Yale University, Institution for Social and Policy Studies.

Guernsey, L. (2000, November 30). Mainstream sites serve as portals to hate. The New York Times, p. G1.

Gurr, T. R. (2000, May/June). Ethnic warfare on the wane. Foreign Affairs, 79(3), 52-64.

Kaplan, S. C. (2000, December 22). The year in technology law [Online]. The New York Times.

Labalme, J. (1999, November 17). Discussion focuses on hate crimes. Indianapolis Star, p. B1.

Levin, J., \& McDevitt, J. (1993). Hate crimes: The rising tide of bigotry and bloodshed. New York: Plenum.

Olzak, S., Shanahan, S., \& McEneaney, E. H. (1996, August). Poverty, segregation, and race riots: 1960 to 1993. American Sociological Review, 61(4), 590-613.

Sherif, M., \& Sherif, C. (1961). Intergroup conflict and cooperation: The Robbers Cave experiment. Norman: University of Oklahoma.

Shlachter, B. (1999, February 27). Jasper breathes a sigh of relief [Online]. Fort Worth Star-Telegram. 


\title{
The Persecution of Gypsies in Europe
}

\author{
MARGARET BREARLEY \\ Advisor on the Holocaust to the Archbishops' Council \\ of the Church of England
}

\begin{abstract}
Roma/Gypsies, nomads newly arrived in Europe in the 1400s, endured expulsions, forcible removal of children, servitude in galleys or mines, death sentences for being Gypsy, and absolute slavery in the Balkans from the 16th century onward. Persecution stemmed from highest authorities in State and Church. Following the murder of 200,000 to 500,000 Roma in the Holocaust, persecution persists, especially in Central and Eastern Europe where Roma form up to $10 \%$ of population (Bulgaria, Slovakia, Romania). Discriminated against under communism, their plight has dramatically worsened since 1989. Endemic problems (low life expectancy, high illiteracy, dire poverty, poor housing) are now heightened by massive, disproportionate unemployment. Unprecedented persecution has been unleashed by new state nationalism and easing of censorship. Roma are the new scapegoat for post-Communist society's ills. The media commonly stigmatize Roma. Few countries have created laws to protect Roma rights. Some activists fear a potential genocide if conditions worsen.
\end{abstract}

The 600-year sojourn of Gypsies in Europe has been hallmarked by repeated acts of hatred against them, as Grattan Puxon (1987) noted: "The history of the Romani people is a story of relentless persecution. From the Middle Ages to the present day, they have been the target of racial discrimination and outright genocide" (p. 1).

Since 1987, the situation of Gypsies throughout Europe has deteriorated sharply. ${ }^{1}$ Numbering 7 to 9 million, they are Europe's largest and, after the Jews, arguably the second oldest minority. They are now the most persecuted minority by far. Leading Rom activists argue that Roma are, post-1989, in a similar situation to that of Jews in 1937 (Gheorghe, 1992a; Holl, 1993; cf. Margalit, 1996); they face mounting oppression in their own countries, yet if they seek to flee as refugees, other nations close the doors to any possible escape.

\section{EARLY HISTORY IN EUROPE ${ }^{2}$}

Roma migrated from India some time before 1000 A.D., moving slowly westwards. They settled in the Balkans by the 14th century and reached all major west European cities by the 15th century. The initial response to these dark-skinned and exotic nomads was often antagonistic but sometimes warm,

AMERICAN BEHAVIORAL SCIENTIST, Vol. 45 No. 4, December 2001 588-599

(C) 2001 Sage Publications 
both among local populations and church and secular authorities. During the 16 th century, however, attitudes hardened. The church feared the very popularity of Gypsy fortune-telling and healing and began spreading anti-Gypsy propaganda. Early agrarian capitalism and war forced many non-Gypsies to become homeless beggars; harsh legislation against all vagabonds was passed throughout western Europe and had a major impact on Gypsies. They became outlaws.

In many countries, including England under Henry VIII, it became a capital offence to be a Rom. If caught, a Rom could be tortured, flogged, branded, and banished. If caught a second time, the penalty was death for men and women. In some countries such as the Netherlands, organized Gypsy hunts became fashionable. Male Gypsies could be sent to the royal galleys, chained as oarsmen for decades or even for life. In Hungary, Germany, Spain, and England, Gypsy children as young as 2 or 4 were taken by force and given to non-Gypsies to rear. (This may well be the source of the myth that Gypsies steal non-Gypsy children. Gypsies are passionately devoted parents and often sought to steal away their own children.)

It is noteworthy that this hatred did not stem primarily from local populations, who have traditionally valued Roma for their peripatetic services; technical skills, such as weaving, smelting, basket-making, and expertise with horses; and facility in music and dance. On the contrary, what has been called "sustained genocidal persecution" of Roma stemmed from the highest authorities, from kings and popes. Nobles and magistrates were forbidden to shelter Gypsies on pain of losing their titles and lands. Pope Pius V tried to expel all Gypsies from the domain of the Catholic Church, prompting Spain, Portugal, and France to start shipping Roma to Africa and America as slaves. In large parts of eastern Europe-especially in what is now Romania-Gypsies were enslaved by princes and monasteries from the 14th century onwards; they were freed from the most abject and cruel slavery only in the 1860s, long after slavery had been abolished in the West Indies.

During the 18th century, efforts to exterminate or expel Gypsies were gradually replaced by forcible assimilation and eradication of the Romany language and identity. Measures were still brutal: forcible settlement of nomadic Roma, forcible seizure of children by the state (this continued in Switzerland until 1973), and imprisonment simply for being Gypsy. In Spain, all male Roma were sent to prisons or mercury mines for up to 16 years; many died.

In the 19th century, persecution of Roma diminished, due partly to Enlightenment notions of tolerance and scholarly interest in Romani language, music, and culture and partly to romantic interest in the Gypsy as "noble savage." However, the Aryan racism of Count Gobineau, Richard Wagner, and others, as well as the social Darwinism that grew from this, resulted in Roma being increasingly stigmatized as racially inferior. In 1876, Cesare Lombroso, in L'uomo delinquente, characterized Roma as atavistic and criminal (Fraser, 1992, p. 249). 


\section{PERSECUTION OF ROMA IN 20TH-CENTURY WESTERN EUROPE}

Germany in particular acted on such distorted concepts. In 1899, the Central Office for Fighting the Gypsy Nuisance was opened in Munich, closing only in 1970. Increasing persecution of Roma throughout Germany culminated in what Roma call the Porrajmos, or "Devouring,": the Nazi Holocaust. Between 200,000 and half a million Gypsies were murdered by Nazis in extermination camps such as Auschwitz and Treblinka or in their home countries by, among others, Croats, Slovaks, Hungarians, and Romanians (Kenrick, 1994/1995). Many Roma were subjected to inhumane medical experiments or were forcibly sterilized. More than half of all German, Czech, Austrian, Polish, and Latvian Gypsies were killed, whereas nearly all Roma in Belgium, Holland, Croatia, Estonia, and Lithuania were annihilated. Documentation exists showing that one ultimate aim of Nazism was the "complete extermination" of the Roma people (Kenrick, 1989; Kenrick \& Puxon, 1995; Polansky, 1998).

Since the Second World War, life has remained hard for Gypsies. In western Europe, nomadism is allowed but has become increasingly difficult because of oppressive laws. Roma generally live in the poorest housing with limited access to health care or education (CDMG, 1995). Policing can be harsh. National legislation and local bylaws increasingly restrict Gypsy life. Roma in western Europe are widely subject to harassment and racism and, especially in Germany, Spain, and Italy, have been victims of significant hate crimes during the 1990s.

\section{LIVING CONDITIONS OF ROMA IN CONTEMPORARY CENTRAL AND EASTERN EUROPE}

In central and eastern Europe, however, conditions are much worse. Indeed, they are so bad that the admission of several former Eastern bloc countries into the European Union (EU) may depend in part on their improving the living conditions of Roma. In most countries, Roma form a substantial proportion of the population: from more than 5\% in Hungary to $9 \%$ to $10 \%$ in Bulgaria, Slovakia, and Romania. ${ }^{3}$ Roma are not only one of the largest ethnic minorities but also the most visible one. Their darker complexion renders them instantly recognizable, and they are often referred to contemptuously as "blacks." Moreover, they are always the poorest and most stigmatized minority, at the very bottom of the social spectrum, with consistently the worst housing, the highest rates of homelessness, illiteracy rates as high as $60 \%$ in some countries, and with life expectancy up to a third lower than that of non-Gypsies.

Because of their different cultural and linguistic background, Roma children are commonly classified as retarded; in Hungary in the mid-1980s, for example, $36 \%$ of all children in "special educational institutions" for "retarded or difficult children" were Gypsies, and 15.2\% of all Rom school children were in schools 
for the handicapped (Crowe, 1995, p. 95). In the Czech Republic, some $20 \%$ of Gypsy children are sent to schools for the mentally handicapped ("European Roma rights," 1997; for a full account, see European Roma Rights Centre [ERRC], 1999); some special schools have between 60\% and 90\% intake of Roma children (Kenrick, 1998, p. 59). Few Roma children attend secondary school; in Romania, 27\% of Roma have never attended school, and only $4.5 \%$ have attended secondary school. Most leave school by age 9 , and only $51.3 \%$ of Roma children under 10 attend school regularly (British Broadcasting Corporation, 1993). Indeed, in many countries, fewer Roma children are in secondary school now than under communism. Their life expectancy rates are far lower than that of the majority populations, ${ }^{4}$ whereas their unemployment rates in the postcommunist era are far higher. ${ }^{5}$

\section{PERSECUTION OF ROMA UNDER COMMUNISM AND POSTCOMMUNISM}

During the 1990s, Roma have become a near-universal scapegoat for the ills of postcommunist society. Renewed nationalistic ideologies have increased hatred of Roma as a stigmatized ethnic group, indeed as a despised caste of virtual untouchables. Hundreds of Gypsies have been murdered in racially motivated attacks and thousands of their homes destroyed by arson.

One direct cause for this outbreak of anti-Gypsy violence is the growing insecurity and economic hardship of the majority populations. As Professor Netanyahu (1995) stated in his recent book on the origins of the Spanish Inquisition, "The majority's toleration of every minority lessens with the worsening of the majority's condition" (p. 5). Under communism, majority intolerance of Roma had been held in check by strong centralized authority and by the institutions of a police state. The state itself was intolerant of Gypsy identity: The Romani language was effectively banned, Roma were allowed to form no political organizations, and from the 1950s, nomadism was forbidden almost everywhere. Roma were often compelled to take on a non-Roma identity and new names as, for example, Bulgarians or Albanians. Self-employment was forbidden and traditional Roma occupations forcibly stopped. Roma were forcibly settled into housing, often in poor shanty towns or factory-owned flats. In Czechoslovakia, thousands of Gypsy women were forcibly sterilized in the 1970s and 1980s (Pellar, 1995; Tritt, 1992, p. x), and many children were placed in orphanages. But, although these assimilationist policies aimed at erasing Gypsy identity, they at least guaranteed to Roma some security (Ofner, 1990). Gypsies did have a modicum of health care, education, housing, and regular paid work as skilled or unskilled laborers. Above all, Gypsies were protected from open discrimination and violence from the majority population.

This protection has now gone. Following 1989, throughout the former communist states, the non-Gypsy majority's condition has worsened; populations 
have faced unprecedented financial insecurity, food shortages, and unemployment. Large-scale crime, corruption, and fraud have increased massively. Former members of the nomenclatura and security forces, indigenous mafia gangs, and international crime syndicates are all involved. Existing justice systems are largely powerless to investigate and prosecute major crime. Yet, petty crime by unemployed Roma - and Roma petty crime undoubtedly has increased since 1989 due to increased poverty and high unemployment rates (Pehe, 1993) — is often tackled by mob violence.

\section{HATE CRIMES AGAINST ROMA IN CENTRAL AND EASTERN EUROPE}

In 1997 in Bulgaria, where Rom unemployment can reach 95\% or even 100\% (Project on Ethnic Relations [PER], 1998, p. 12) and many Roma receive no welfare benefits, Romani petty thieves suffered lynch justice that would not have been applied to non-Gypsies. Five men and two girls caught trying to steal five lambs were tied to a tractor and beaten by locals; a Rom was tied to a tree for 7 hours for stealing potatoes and onions (The Sofia Echo, 1997). Other Romani petty thieves were publicly caned. In Hungary in 1992, a farmer shot dead two Roma stealing pears (Braham, 1993, pp. 39-40; Crowe, 1995, p. 104). Popular anger against Gypsies can thus serve to deflect widespread popular anger and frustration at less visible — and far more powerful—non-Gypsy criminals.

Hatred of Roma, latent but suppressed under communism, can now be expressed openly. This hatred combines racism, contempt for Roma poverty, resentment for perceived past favoritism toward Roma under communism, and newly found nationalism. A leading Rom activist, Nicolae Gheorghe (1992b), has stated, "Before the revolution, only the police were violent to Romanies. Now the whole population can be." Individual events can trigger disproportionately massive hate crimes against Roma. "An individual mugging, rape or knife fight involving a single Rom can result in the burning of many or all houses of the whole Roma community" (Snagov Conference Report, p. 16). The following is one of many examples: In Bolentina, Romania, in 1991, after a Rom allegedly raped a village woman, 1,000 villagers drove 137 Roma families from their homes and burned the houses of 26 families to the ground as "retaliation" (The Times, 1992). Numerous Roma have died in such arson attacks since 1991.

Mob violence also occurs in response to actions by the authorities: For example, when Roma are forcibly resettled, local villagers or townspeople often violently expel them or set fire to Roma housing. During the 1990s, there have been major pogroms against Rom communities in Poland, Hungary, Slovakia, and Romania (where 30 pogroms occurred between 1990 and 1995, involving lynchings, torching of Rom homes, permanent expulsions, and the deaths of several Roma) ("Lynch Law," 1994). Local instigators of mob violence are rarely prosecuted; instead, assaults on Roma communities are often blamed on the 
victims themselves, whereas racial motives for such attacks are consistently denied by the authorities.

\section{THE ROLE OF SKINHEADS}

The main culprits in hate crimes against Roma are, however, skinheads. Organized groups of skinheads now exist in most former communist states. They are relatively few in number (in the Czech Republic only 5,000), but they enjoy considerable support in the wider population. In Hungary, nearly a quarter of a million young Hungarians fully or partly identify with skinheads (Welfare Ministry statistics, as cited in Kovats, 1994, p. 10). Skinheads are well organized both nationally and internationally and have links to far right political parties. Their ideology is openly neo-Nazi, racist, and violent. In their version of "White supremacy," there is no room for "black" Roma. A widespread skinhead slogan is "Roma to the gas chambers" (European Centre for Research and Action, 1994, p. 19). Although they have murdered Indians, Turks, and other foreigners, the vast majority of their victims have been Gypsies. In the Czech Republic alone, at least nine Roma have been murdered by skinheads since 1991 (Patrin, 1997). Skinheads have killed dozens more in Bulgaria, Serbia, and Slovakia, and many hundreds of Roma have been badly injured in skinhead attacks across central and eastern Europe (ERRC, 1997b).

\section{ROMA VIS-A-VIS CRIMINAL JUSTICE}

Few of those responsible are ever brought to justice, partly because many skinheads are still in their teens and partly because of the sympathy they enjoy among the wider population and the police. Indeed, some skinheads are themselves the sons of policemen. When skinheads are occasionally arrested and found guilty, their sentences are always light.

Indeed, one can argue that in many former Eastern bloc countries, the justice system itself and especially the police are guilty of hate crimes toward Roma. There is little tradition in former communist countries of neutral policing; police commonly display the same deep prejudices as those of the wider population. Ample evidence now exists of police contempt for Roma, expressed in racist insults and often violent behavior. In countries such as Romania, for example, there are frequent and violent dawn raids on Roma communities using excessive force to instill fear (ERRC, 1996b, pp. 20-44).

One consistent hallmark of police hatred is that if Roma victims of a crime go to the police, they are then frequently accused themselves of having committed that or another crime. Thus, the innocent Gypsy victim becomes the guilty party, whereas the non-Gypsy culprit conveniently goes unpunished. In some countries, police boost their incomes by regularly demanding bribes and extortionate 
fines from Roma and by confiscating their property (Helsinki Human Rights Watch Report, 1996a, 1996b, pp. 15-28, 34-37).

There is now substantial evidence from several central and eastern European countries of endemic physical abuse, torture, and indeed killings of Roma both in police custody and in prisons (ERRC, 1996b; Helsinki Human Rights Watch Report 1996a, 1996b). ${ }^{6}$ There are commonly no legal mechanisms for Roma to instigate proceedings against police involved in such violence. Roma throughout central and eastern Europe have a well-justified fear of police and security forces. It is almost universally the case that minor crime committed by Roma is punished overzealously, whereas serious crime against Roma receives little or no punishment. It is commonplace for police, prosecutors, and judges to downplay or outright deny the existence of hate crimes toward Roma. This, in turn, encourages the perpetuation of hate crimes because perpetrators know that they are likely to remain immune from prosecution.

\section{POPULAR “ANTI-GYPSYISM”}

It is clear from recent public opinion polls that hatred of or contempt for Roma is widespread within the populations of former communist countries. In Croatia, for example, the Roma are the most disliked among all 30 ethnic minority groups, whereas in the Czech Republic, $87 \%$ of Czechs polled in November 1996 objected to having Roma neighbors, and about $50 \%$ wanted to expel Roma from Czech territory (Institute for Jewish Policy Research and American Jewish Committee, 1997, p. 131). These statistics are typical of most countries in the region. On this basis, one could argue that hate crimes against Roma simply reflect a grassroots phenomenon, an innate antipathy to Roma based on racism and fear of "the other."

The situation is, however, far more complex. Anyone who knows the history of anti-Semitism is well aware that anti-Semitism has generally been inculcated from the top down. From Hellenistic times onwards and especially within Western Christendom, state legislation, ideological writings by intellectuals, propaganda, and inflammatory speeches have all contributed toward the growth of popular anti-Semitism.

So it is with what has been called "Romophobia," hatred of Gypsies. Since 1989 , this hatred has been fanned and even taught by some national governments, by many local authorities, by right-wing political parties, and by the media. Any discussion of violent hate crimes against Roma cannot ignore this complicity by those in positions of leadership.

\section{STATE LEGISLATION AND ROMA}

A few governments, such as Hungary and Slovakia, have passed legislation to protect Roma as a national minority, and several others, including Bulgaria, 
have restored many civil and political rights to Roma. But other governments have legislated to exclude as many Roma as possible. The prime example is that of the Czech Republic; it became known in 1992 that the Czech government had prepared a secret report planning to expel all Gypsies in the Czech Republic to Slovakia. Eventually, prior to the split with Slovakia in 1993, Czechoslovakia created such stringent citizenship laws that more than 100,000 Roma living in the Czech Republic who could not fulfill the criteria were left stateless. They were unable to claim any social security or welfare benefits (Brearley, 1996, pp. 19-20). In 1999, several thousand Roma in the Republic were still stateless.

Western governments have followed similar patterns of excluding and then deporting Roma. Between 1991 and 1993, Austria created new asylum and residence laws enabling it to deport large numbers of Roma who had been living legally in Austria for many years, as well as virtually all Roma asylum seekers (ERRC, 1996a). Germany has repatriated tens of thousands of Roma asylum seekers from Romania, Yugoslavia, and elsewhere. Expulsions of Roma at a national level also occur as part of ethnic cleansing; many were deported from Croatia and Bosnia during the recent Balkan wars, during which Roma were forced to clear mine fields and dig frontline trenches (Liegeois \& Gheorghe, 1995, p. 18; Official Bulletin of the International Romani Union, 1992, p. 11.XII; The Times, 1994), and in Kosovo, where tens of thousands of Roma had to flee their homes, they were forced to bury corpses.

Local authorities can send similar messages of contempt for Gypsies through their own expulsions of Roma. Throughout eastern Europe, large numbers of Roma have been made redundant by state-owned factories and then expelled from urban work-linked flats owned by municipal authorities. Privatization of much of the housing market and the restoration of publicly confiscated land to its former private owners has led to evictions of many Roma families, particularly from rural settlements. Some town mayors have intensified local hostility to Roma, in some cases going so far as to build street walls to divide Gypsies from their neighbors, such as in Madrid, 1994, and Usti nad labem, Czech Republic, 1999; or to evict large numbers of Roma (5,000 from the Selamsiz quarter of Istanbul, 1996).

\section{ROMA AND THE PUBLIC RHETORIC OF HATE}

Moreover, the rhetoric of officials in both local and national government can inflame hatred of Roma. Slovakia is a prime example: In 1993, Prime Minister Vladimir Meciar described Roma as "antisocial, mentally backward, unassimil-

able and socially unacceptable." He demanded a reduction in family welfare payments to lower the reproduction of these "mentally retarded" people (Fakete \& Webber, 1994).

Right-wing political parties, too, are guilty of hate rhetoric. In Italy, where six Roma children have died in hate crimes since 1994 and several others have been 
seriously wounded, a Northern League member of Parliament described Roma camps outside Florence as "a gathering of thieves and prostitutes, muggers and rapists" and called for Roma to be prevented from entering Florence (Institute of Race Relations European Race Audit, 1995). In Poland, the National Front Party circulated pamphlets demanding that all 90,000 Polish Roma (three times the actual number) be banished and has circulated fly porters with slogans such as "Death to Gypsies" and "Gas the Gypsies" (Braham, 1993, p. 92). Nationalist parties in Romania, Russia, Germany, and elsewhere are responsible for similar anti-Gypsy xenophobia. They, like skinheads and some eastern European governments, would like Roma to emigrate en masse.

\section{THE PORTRAYAL OF ROMA IN THE MEDIA}

The media also play a major part in creating hatred of Roma. Although since the early 1990s there have been occasional articles about the economic distress of Roma or romantic aspects of their culture such as music, most reporting on Gypsy affairs is sensationalist, exaggerated, and negative. Language typical of anti-Semitism is often used of Roma. In 1992, for example, two leading German newspapers described Gypsies as "a pure disease" and "a serious plague" (Brearley, 1996, p. 23). Throughout Europe and especially in former communist states, Gypsies are commonly presented in the media in gross stereotypes: as parasites, as genetic criminals, as dangerous. In Bulgaria, for example, there has been "persistent media stigmatising of Roma" since 1989. The media portray Roma as inherently deviant, typifying them as "villains," "incorrigible perpetrators," and "apt to commit crimes." Crime statistics in newspapers are always presented in two columns, "Roma" and "non-Roma," with exaggeratedly high rates shown for Roma crime (Anguelova, 1996; ERRC, 1997a, pp. 18-19; Project on Ethnic Relations, 1996). ${ }^{7}$ The same is true for Romania, where in any report on Roma crime, the ethnicity of the alleged perpetrator is always given. This does not happen with crimes committed by any other ethnic group (PER, 1997, pp. 6-8).

There is thus little more neutral journalism than there is neutral policing. The presumption is always on Roma guilt and the innocence of non-Romanies. There is little media interest in positive aspects of Roma life or sympathy with their widespread persecution and no interest in praising Roma values or outstanding public figures (said to include Ava Gardner, Yul Brynner, and Charlie Chaplin). The effect of this undiluted stigmatizing by the media is powerful. Indeed, at a conference in 1996 on the media and Roma in contemporary Europe, organized by the PER, a delegate from the Organisation for Security and Cooperation in Europe (OSCE) argued that according to the OSCE, "anti-Roma violence was the result of racial discrimination in the media, which then became institutionalised in people's minds" (PER, 1996, pp. I, 4). 


\section{THE LACK OF NON-ROMA POLITICAL SUPPORT}

A further element exacerbating hate crimes is the failure of non-Romany leadership to speak out on behalf of Roma. For example, although there are now within the EU, the OSCE, and nongovernmental organizations many national and international initiatives to assist Roma, trade unions and the churches have remained notably silent in the face of anti-Roma violence. Not until March 1998 did a joint conference of Catholic and Moravian bishops in the Czech Republic make a joint appeal on behalf of Roma in their country. Churches in most other states where Roma are persecuted remain silent.

In this brief article, it is impossible to give a comprehensive account of the current persecution of Roma in Europe. But, even this short summary should suffice to indicate the urgency of their situation. Facing discrimination by national governments and local authorities; denied safe havens as refugees; targeted by a hostile media; and the victim of increasing hatred, violence, and murder from lynch mobs, skinheads, and the police, the Roma of Europe face a bleak future.

To love liberty should mean to stand with and on behalf of Roma. A Romany prayer states, "A land without Gypsies is a land without freedom." ${ }^{.8}$ A Romany proverb runs, "Cursed is the land from which Gypsies flee" (O Drom, 1990). But, Gypsies have no land to which they can flee, and in some of the lands where they have lived for centuries there is arguably a genocidal situation in the making.

\section{NOTES}

1. Noted most recently in an Organisation for Security and Cooperation in Europe study on Roma prepared by Max van der Stoel (2000).

2. Compare Fraser (1992), Crowe (1995), and Hancock (1987). For a comprehensive bibliography on Roma, see Tong (1995).

3. Government census figures on Roma populations are often unreliable. For plausible statistics, see Liegeois and Gheorghe (1995, p. 7).

4. E. Kalibova (1995) suggested that Rom life expectancy approximates to that of Czech non-Gypsies in the 1930s, whereas estimates of life expectancy of Hungarian Roma range between 32 and 55 to 60 years (Braham, 1993, p. 42).

5. In the Czech Republic, unemployment rates are $40 \%$ to 50\% (Obrmann, 1991); in some regions of Hungary, unemployment rates reach $50 \%, 80 \%$, or even $100 \%$ (Braham, 1993, p. 35; Crowe, 1995, p. 103).

6. In Bulgaria, 14 Gypsies died between 1992 and 1998 while in police custody or as a result of police shootings (Manchester Guardian, 2000), and in the first half of 1997 alone, 528 cases of abuse by police officers against Roma were reported (European Roma Rights Centre, 1997a, p. 22).

7. Further examples in The Sofia Echo, September 25 through October 1, 1998, pp. 10-11.

8. Cited in Diveso, a Gypsy newsletter in Albania. 


\section{REFERENCES}

Anguelova, K. (1996, March-April). Romophobia in the media. Focus: Newsletter of the Human Rights Project [Facts and Fiction], I, 1, 13-15.

Braham, M. (1993). The untouchables: A survey of the Roma people of central and eastern Europe. Geneva, Switzerland: Office of the United Nations High Commissioner for Refugees.

Brearley, M. (1996, December). The Roma/Gypsies of Europe: A persecuted people. London: Institute for Jewish Policy Research.

British Broadcasting Corporation. (1993, April 12). Summary of world broadcasts (SWB). London: Author.

Cahn, C. (1996, September). Divide and deport: Roma and Sinti in Austria. Budapest, Hungary: European Roma Rights Centre.

CDMG, European Committee on Migration. (1995, May). The situation of Gypsies (Roma and Sinti) in Europe. Strasbourg, France: Council of Europe.

Crowe, D. M. (1995). A history of the Gypsies of eastern Europe and Russia. London: I. B. Tauris \& Co.

European Centre for Research and Action on Racism and Antisemitism. (1994). Political extremism and the threat to democracy in Europe: A survey and assessment of parties, movements and groups. London: Institute of Jewish Affairs.

"European Roma Rights Center on Events in Great Britain." (1997, October 22). Patrin Romani News.

European Roma Rights Centre. (1997, January). Time of the skinheads: Denial and exclusion of Roma in Slovakia. Budapest, Hungary: Author.

European Roma Rights Centre. (1999, June). A special remedy: Roma and schools for the mentally handicapped in the Czech Republic. Budapest, Hungary: Author.

Fakete, L., \& Webber, F. (1994). Inside racist Europe. London: Institute of Race Relations.

Fraser, A. (1992). The Gypsies. Oxford, UK: Blackwell.

Gheorghe, N. (1992a, September 30). Gypsies are now the scapegoats as the Jews were before. The Times.

Gheorghe, N. (1992b, September 30). Letter to The Times. The Times.

Glenny, M. (1994, April 6). "Time runs out in a Balkin powderkeg". The Times (Online).

Gughinski, N. (1997a, December). Profession: Prisoner. Roma in detention in Bulgaria. Budapest, Hungary: European Roma Rights Centre.

Hancock, I. (1987). The pariah syndrome: An account of Gypsy slavery and persecution. Ann Arbor, MI: Karoma.

Helsinki Human Rights Watch Report. (1996a). Children of Bulgaria: Police violence and arbitrary confinement. Helsinki, Finland: Author.

Helsinki Human Rights Watch Report. (1996b). Rights denied: The Roma of Hungary. Helsinki, Finland: Author.

Holl, K. (1993, June-August). The East European Roma have today the same role as the Ostjuden earlier in this century. Regards.

Institute for Jewish Policy Research and American Jewish Committee. (1997). Antisemitism world report 1997. London: Author.

Institute of Race Relations. (1995, March). European Race Belletin. London: Author.

Kalibova, E. (1995). La situation demographique de la population tzigane en Tchecoslovaquie [The demographic situation of the Gypsy population in Czechoslovakia]. In C. Auzias (Ed.), Les familles Roms d'Europe de l'Est [The Romany families of Eastern Europe]. Paris: Editions Michalon.

Kenrick, D. (1989). Letter to the editor. Holocaust and Genocide Studies, 4(2), 251-254.

Kenrick, D. (1994/1995, Winter). The Nazis and the Gypsies: A fresh look. Jewish Quarterly, 156.

Kenrick, D. (1998, July). Gypsies: Life on the edge. Index on Censorship, 27(4), 55-62.

Kenrick, D., \& Puxon, G. (1995). Gypsies under the Swastika. Hatfield: University of Hertfordshire Press. 
Kovats, M. (1994). The political development of the Hungarian Roma. Unpublished master's dissertation, School of Slavonic and East European Studies, London.

LeBore, A. (1992, September 30). Hatred of Gypsies lurks beneath Romania's surface calm. The Times (Online).

Liegeois, J-P., \& Gheorghe, N. (1995). Roma/Gypsies: A European minority (Minority Rights Group report). London: Minority Rights Group.

"Lynch law: Violence against the Roma in Romania." (1994, November). Helsinki Human Rights Watch, 6(17).

Margalit, G. (1996). Antigypsyism in the political culture of the federal republic of Germany: A parallel with antisemitism? In Analysis of Current Trends in Antisemitism (No. 9). The Hebrew University of Jerusalem: Vidal Sassoon International Center for the Study of Antisemitism.

Netanyahu, B. (1995). The origins of the Inquisition in fifteenth century Spain. New York: Random House.

O Drom. (1990, April), p.35.

Obrmann, J. (1991, December). Minorities not a major issue yet. RFE/RL Research Report, 11.

Official bulletin of the International Romani Union. (1992). Berlin: International Romani Union.

Ofner, P. (1990, April). O Drom, 34-35.

Pehe, J. (1993, February). Law on Romanies causes uproar in Czech Republic. RFE/RL Research Report, p. 19.

Pellar, R. (1995). La fecondite n'est plus en vente [Fertility is no longer on sale]. In C. Auzias (Ed.), Les familles Roms d'Europe de l'Est (pp. 66-70). Paris: Editions Michalon.

Polansky, P. (1998). Black silence: The Lety survivors speak. Prague, Czechoslovakia: G plus G: Cross-Cultural Communications.

Project on Ethnic Relations. (1996, September). The media and the Roma in contemporary Europe. Princeton, NJ: Author.

Project on Ethnic Relations. (1997, June 27-28). Images and issues: Coverage of the mass media in Romania [Report of the Project on Ethnic Relations Conference]. Princeton, NJ: Author.

Project on Ethnic Relations. (1998, April). The Roma in Bulgaria: Collaborative efforts between local authorities and nongovernmental organizations. Princeton, NJ: Author.

Puxon, G. (1987). Roma: Europe's Gypsies. London: Minority Rights Group.

The Sofia Echo. (1997, August 8-14), p. 1.

Steele, J. (2000, April 8). "Gypsies feel the lash of everyone's hatred.” Manchester Guardian, p. 19.

Szente, V. L. (1996, September). Sudden rage at dawn: Violence against Roma in Romania. Budapest, Hungary: European Roma Rights Centre.

The Times. (1992, August 30).

Tong, D. (1995). Gypsies: A multidisciplinary annotated bibliography. New York: Garland.

Tritt, R. (1992). Struggling for ethnic identity: Czechoslovakia's endangered Gypsies. New York: Helsinki Human Rights Watch Report.

van der Stoel, M. (2000, April 7) Report on the Situation of Roma and Sinti in the OSCE Area, Office of the High Commissioner on National Minorities, The Hague: Organisation for Security and Co-operation in Europe.

Watts, L. (1994, July). Countering anti-Roma violence in Eastern Europe: The Snagov Conference and related efforts. Project on Ethnic Relations Snagov Conference report (p. 16). Princeton, NJ: Project on Ethnic Relations. 


\title{
Aggressive Youth \\ Cultures and Hate Crime
}

\author{
Skinheads and Xenophobic Youth in Germany
}

MEREDITH W. WATTS

University of Wisconsin-Milwaukee

\begin{abstract}
Contemporary bias crime in Germany increased dramatically after unification and remained at a relatively high, though fluctuating, level for the decade. Right-wing skinheads and neo-Nazis played a significant role in the violence, but at least one third of the violent incidents came from informal groups of young males who were not affiliated. This represents a shift in anti-Semitic and antiforeigner violence from the 1980s and earlier, when the perpetrators were likely to be older and affiliated with identifiable ideological groups. Contemporary xenophobia is not only linked to aggressive elements of youth culture but appears to be increasingly connected to local and international ideological networks. Electronic media such as the Internet have given both the political and commercial entities of skinhead and right-wing culture a means of support and growth.
\end{abstract}

Xenophobic aggression in postunification Germany is not identical with what is called hate crime or hate violence in the United States, nor are the official data kept by the Federal Office for the Protection of the Constitution to monitor bias-inspired crimes directly comparable with U.S. definitions. The law in the Federal Republic of Germany reflects a reaction against the Nazi past and aims to forbid "Nazi" speech and propaganda. The law also provided for the monitoring of acts motivated by right-wing extremism, anti-Semitism, and antiforeigner bias. This produces several special categories of crime that may seem unusual to citizens of the United States, such as (a) disturbing or defaming the dead (the charges invoked to sanction desecration of Jewish grave sites and memorials), (b) "public incitement" and "instigation of racial hatred" (charges used to suppress racist public speech), and (c) distribution of Nazi propaganda or "literature liable to corrupt the young."

Other aspects of German law forbid the promotion of a Nazi-like political party, denial of the Holocaust, and use of the symbols associated with officially banned groups. The latter provision criminalizes the display of Nazi-era symbols (e.g., the swastika, the "Hitler greeting") but has been steadily expanded to

AMERICAN BEHAVIORAL SCIENTIST, Vol. 45 No. 4, December 2001 600-615

(C) 2001 Sage Publications 
forbid a wide variety of flags, emblems, and other symbols that were employed by groups banned by the Federal Constitutional Court.

What these laws do not do (compared to bias crime legislation in the United States) is define hate crime or hate violence as such, nor do they include any special recognition of gender, disability, or sexual orientation. On the other hand, they go much further than laws in many other contemporary democracies in limiting certain types of biased or racist speech, particularly when it is directed at groups victimized in the Holocaust.

Although the German law obviously reflects a special set of historical and legal circumstances, it results in an exemplary national data effort in certain categories of bias crime. The law requires national reporting of incidents by all police agencies. This ensures data gathering that is more intensive and more complete than is currently the case in most other nations (particularly in comparison with the United States where hate crime reporting is still voluntary and highly variable). As a result, German data provide a better basis than that of most nations for examining trends and developments in certain categories of hate-motivated violence. This feature of the law makes it possible to analyze trends in right-wing and xenophobic ${ }^{1}$ violence in Germany, developments that reflect a particular national situation but that also show international characteristics that may help us understand hate violence in other societies as well.

\section{THE COURSE OF RIGHT-WING VIOLENCE}

Perhaps the first question concerns the basic historical development of right-wing violence in Germany. Table 1 and Figure 1 place the era of "modern" xenophobia in Germany in perspective. In 1989 and 1990, immediately prior to unification, there were fewer than 200 violent incidents per year. That figure more than quadrupled by 1992 and reached its contemporary peak in the following year. Shock of the German public (expressed dramatically by candlelight processions in sympathy with the victims), consolidation of the criminal justice agencies in the new federal states in the east, and stepped-up enforcement activities by security agencies all played a part in the decline. Since then, there have been oscillations between 600 and 800 violent incidents per year-a decline from the peak but still high compared to the preunification period (for a more extended discussion, see Watts, 1997, chap. 2).

A second question concerns the targets of violence. Unlike federal (and some state) hate crime statutes in the United States, German law does not provide for special reporting of violence based on sexual orientation, gender, or disability. However, it is quite specific about crimes that can be attributed to anti-Semitic, antiforeigner, or right-wing motivation. Since unification (beginning officially in 1990), the targets of attack have remained relatively constant. As Table 2 shows, about $60 \%$ of the violent incidents have been directed against foreigners. Anti-Semitic attacks, including desecration of graves and memorial sites, have 
TABLE 1: The Course of Right-Wing Violence in Germany, 1989-1998

\begin{tabular}{lc}
\hline Year & Number of Violent Acts $^{\mathrm{a}}$ \\
\hline 1989 & 173 \\
1990 & 178 \\
1991 & 849 \\
1992 & 1,485 \\
1993 & 1,322 \\
1994 & 784 \\
1995 & 612 \\
1996 & 624 \\
1997 & 790 \\
1998 & 708 \\
\hline
\end{tabular}

SOURCE: Bundesamt für Verfassungsschutz [Federal Office for Protection of the Constitution] (1997, 1998d). See also Watts (1997, chap. 2).

a. The official term refers to violent acts "with demonstrated or assumed right-wing motivation."

accounted for about $2 \%$ of all violent incidents. Foreigners are a significant presence in Germany (with a population of more than 7 million) and account for the vast majority (60\%) of attacks against persons. By contrast, the number of Jews in Germany is probably not much more than one hundredth that of foreigners, even allowing for a doubling of the Jewish population over the decade (due primarily to immigration from the former Soviet Union). Thus, whereas only $2 \%$ of the total offenses involve Jewish persons or institutions, the per capita rate is high.

Political opponents such as "autonomous" leftist groups and rival youth cultures accounted for another $14 \%$ of the total. The last category ("other") contained $24 \%$ of the incidents; it refers to offenses where the perpetrators were identifiably right wing but the victims were not foreigners, Jews, or political enemies (examples might be damage to property during a demonstration or assaults against police or bystanders).

\section{WHO ARE THE PERPETRATORS?}

But who are these "rightists?" Increasingly, the perpetrators of hate violence of the past decade have tended overwhelmingly to be young males, usually acting in groups. But how young? And in what kind of groups-skinheads, neo-Nazis, or informal groups of young men looking for excitement? ${ }^{2}$ As Table 3 shows, modern xenophobia indeed has a youthful face. Data from 1996 show that $30 \%$ of the perpetrators were ages 16 to 17 and that more than two thirds of all perpetrators were 20 years of age or younger.

This aggressive activism on the part of teenaged and young adult males represents a historical "modernization" of xenophobic violence. Prior to 1980, those 


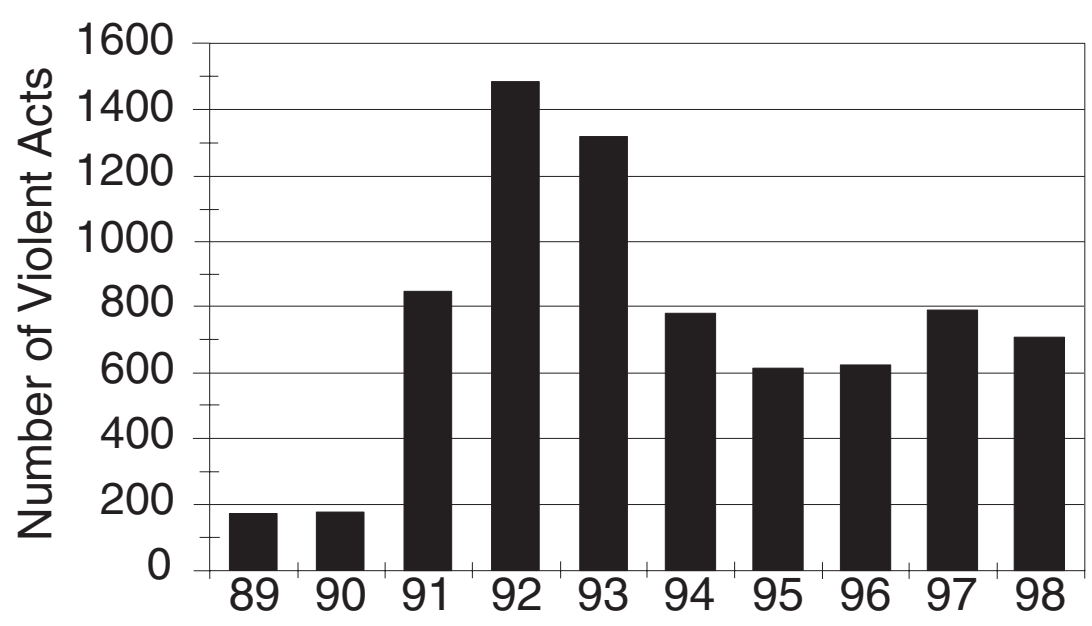

Figure 1: Right-Wing Violence

SOURCE: Verfassungsschutzbericht $(1997,1998)$

TABLE 2: Targets of Right-Wing Violence in Germany, 1995-1998

\begin{tabular}{|c|c|c|}
\hline Type & Number of Offenses ${ }^{\mathrm{a}}$ & Percentage of Total \\
\hline Antiforeigner & 1,269 & 60 \\
\hline Anti-Semitic & 38 & 2 \\
\hline Against political opponents & 303 & 14 \\
\hline Other $^{\mathrm{b}}$ & 512 & 24 \\
\hline Total & 2,122 & 100 \\
\hline
\end{tabular}

SOURCE: Bundesamt für Verfassungsschutz [Federal Office for Protection of the Constitution] (1997, 1998d).

a. The official term refers to violent acts "with demonstrated or assumed right-wing motivation."

b. "Other" includes acts of violence where the perpetrators are identified as "rightists" but where the incident or target does not involve the previous three categories. Examples might be a march in which store windows are broken or a confrontation with citizens or bystanders.

younger than 20 years of age accounted for only $40 \%$ of the incidents (see Watts, 1997, p. 269). The earlier form of rightist activism involved somewhat older perpetrators who were more likely to be associated with neo-Nazi groups (and, presumably, had more developed right-wing ideological positions than today's younger activists). In comparison with this earlier period, today's typical activist is much younger ${ }^{3}$ and less likely to be a member of a neo-Nazi organization.

Accompanying this shift toward youthful activism has been a trend away from classic, membership-based organizational forms. The young perpetrators 
TABLE 3: Age of Perpetrators (1996)

\begin{tabular}{lcc}
\hline Age & Percentage & Cumulative Percentage \\
\hline $16-17$ & 30 & 30 \\
$18-20$ & 37 & 67 \\
$21-30$ & 27 & 94 \\
$31-40$ & 3 & 97 \\
Older than 40 & 3 & 100 \\
\hline
\end{tabular}

SOURCE: Bundesamt für Verfassungsschutz [Federal Office for Protection of the Constitution] (1996). (For earlier years, see Watts, 1997, p. 269.)

are less likely than their predecessors to be ideologically sophisticated and organizationally connected. This does not mean they are isolated; on the contrary, they are part of a xenophobic culture that includes both the older organizational forms and a heterogeneous (and often highly spontaneous) youth culture. This last point is not an obvious one, but we can make sense of it looking at recent skinhead history and at the data on the organization connections of actual perpetrators. Here, we have two questions: How have developments in the skinhead scene contributed to the subculture of racism? and How much have skinheads contributed to the rise in violence?

\section{TRENDS IN EXTREMISM AND AGGRESSIVE SUBCULTURES}

Historically, only a portion of the skinhead style has been explicitly racist or neo-Nazi. Most histories of the movement point to its British working-class origins and to its multiracialism in membership and music tastes. But, those accounts also point to the split of the skinheads into "left" and "right" factions in the 1980s. Somewhere in between these politicized factions are the apolitical skins (who probably make up the majority). The actual numbers in each group are difficult to identify because the boundaries are fluid, and stylistic variations are not always recognizable to the outsider. To make things more difficult, it is not unusual for German skins to refer to themselves as "more or less left" when they actually mean that they are not right. For young Germans in the east, to be truly left was largely discredited with the fall of the East German regime. This was particularly the case for skinheads, who were likely to see being right as the logical place for rebellion to take place in a socialist society.

The right-wing scene has been notorious for its fluidity and unpredictable actionism, a frustration both for the more orthodox rightists who would like to organize them and for the security agencies who would like to monitor them. However, there is a countervailing tendency that seems to have been 
accelerating throughout the decade-there are signs that such international groups as the Blood and Honour (British) and the Hammerskins (United States) have added discipline, ideology, and an international network to the right-wing skinhead culture. Not only do both movements have global pretensions, but the latter group refers to itself, ominously, as the Hammerskin Nation.

All this points to a rightist milieu that contains a diverse mix of elementsinformal groups of xenophobic youth; "subcultures" with a recognizable, aggressive style (such as skinheads); and ideological groups that are disciplined and organized. Those who identify themselves as rightist skinheads are a dramatic presence among perpetrators (Anti-Defamation League, 1995; Hamm, 1993), but available data suggest that they are only one part of a much broader class of aggressive xenophobes.

In his study of perpetrators in the early 1990 s, Willems found that $38 \%$ of those arrested for antiforeigner violence in the early 1990s were identified as skinheads (Willems, 1995). Heitmeyer and Müller (1995) found that 46\% of their interviewees who were involved in antiforeigner violence thought of themselves as skinheads. Prior to 1990, however, the term skinhead hardly surfaced with respect to anti-Semitic or antiforeigner violence-not only was there a smaller amount of violence, but some $90 \%$ of the perpetrators in that earlier period were identified with neo-Nazi or other classic right-wing extremist groups (Kalinowsky, 1990). In other words, the 1990s were characterized by a surge in xenophobic violence that was carried by aggressive subcultures that were different from the traditional ideological groups on the right.

In comparison to Germany, information on the role of skinheads in the United States is somewhat less systematic and therefore less conclusive. Levin and McDevitt (1993) estimated that the most ideological perpetrators of hate crimes are probably no more than $1 \%$ of the total perpetrators. The authors suggested that skinheads are part of this group of violent perpetrators who attack out of an ideological "mission" to drive out the target group. However, data from Germany and elsewhere suggest that skinheads and other aggressive subcultures may not act primarily from racial or ideological motivations but are motivated by "thrill-seeking" and other opportunistic or criminal motives. Thus, it is difficult to estimate the contributions of skinheads in the perpetration of hate crimes or bias-motivated attacks and just as difficult, at the moment, to compare accurately the various types of perpetrators from one nation to another.

Direct comparison across nations is also made difficult because of the nature of the data (compared to Germany, police reports in the United States are less systematic in establishing the political motivation or membership of the perpetrators). As a result, figures from the United States are not comparable (either in relative accuracy or in estimated magnitude) with that of Germany; however, it is clear that racist skinheads are involved in a number of dramatically violent incidents nationally and internationally (Anti-Defamation League, 1995; Southern Poverty Law Center, 1998). 
Thus, to reiterate an obvious point: Only some skinheads are racists, and most racists are not skinheads. Yet, skinheads have played a growing role in xenophobic violence. But, what do we know of the "skinhead" contribution to the broader culture of aggressive xenophobia? To put the numbers in perspective, Willems (1995) found that in addition to the $38 \%$ who were identifiable with skinhead culture in some way, about $25 \%$ of the perpetrators were associated with right-wing extremist groups. Another $19 \%$ were members of informal groups or cliques with no specific ideological identification (most of the remaining perpetrators not accounted for in the above categories had prior records and were classified as "criminal," though this category no doubt overlaps the others). Heitmeyer and Müller (1995) found that roughly $27 \%$ of the rightist youth they interviewed were associated with neo-Nazi (rather than skinhead) groups. Taken together, these studies indicate that skinheads make up the largest single category of perpetrators in Germany, with members of neo-Nazi organizations a distant second. By either account, at least one third of the attacks are committed by youth who are not associated with these easily identifiable groups.

Skinheads have represented a major portion of the problem, but they were still only one part of a much broader pattern of violence. According to the German Federal Office for the Protection of the Constitution, the total estimate of "right-wing extremist potential" in Germany grew steadily in the last half of the 1990s. A closer look at the various groups (see Table 4) shows that the largest single numerical change has occurred in the estimated strength of rightextremist political parties (these are parties that are "on watch" by the agency but are not classified/banned as "neo-Nazi"). The number of hard-core ideologues represented by the neo-Nazis has remained relatively constant; other growth areas have been among those classified as "violence-prone rightists" and "other groups" (see Figure 2). The latter category contains a diverse cluster of Kameradschaften, discussion groups, and informal cliques that seem to have proliferated (but whose numbers are notoriously hard to estimate due to their informal organizational forms).

Also hard to estimate is the exact number of persons in the violence-prone category; yet, it is on this diffuse group that the federal office has focused much of its concern over the decade. This category contains the heart of the perpetrator category-potentially violent young people (mostly males); its numbers are largely a matter of estimate (because there are no "organizations" to infiltrate or membership records to confiscate). It is this category that contains the skinheads, the group with the most identifiable style and appearance among the violence prone. Obviously, the German government views this category as a growing source of danger. The rise in the number estimated to be violence prone thus reflects an increase in aggressive youth. It is also likely that the increase in their estimated numbers results from a heightened perception on the part of monitoring agencies that the danger from unorganized, aggressive youth is growing. If the numbers are truly on the rise, then it is an increase in the potential-rather 
TABLE 4: $\quad$ Estimated Right-Wing Extremist Potential, 1995-1998

\begin{tabular}{lrrrr}
\hline & \multicolumn{4}{c}{ Year } \\
\cline { 2 - 5 } Extremist Group & 1995 & 1996 & 1997 & 1998 \\
\hline Violence-prone rightists & 6,200 & 6,400 & 7,600 & 8,200 \\
Neo-Nazis & 1,980 & 2,420 & 2,400 & 2,400 \\
Political parties & 35,900 & 33,500 & 34,800 & 39,000 \\
Other groups & 2,660 & 3,700 & 4,300 & 4,500 \\
Total & 46,740 & 46,020 & 49,100 & 54,100 \\
Total minus multiple memberships & 44,610 & 45,300 & 48,400 & 53,600 \\
\hline
\end{tabular}

SOURCE: Bundesamt für Verfassungsschutz [Federal Office for Protection of the Constitution] (1997, 1998d).

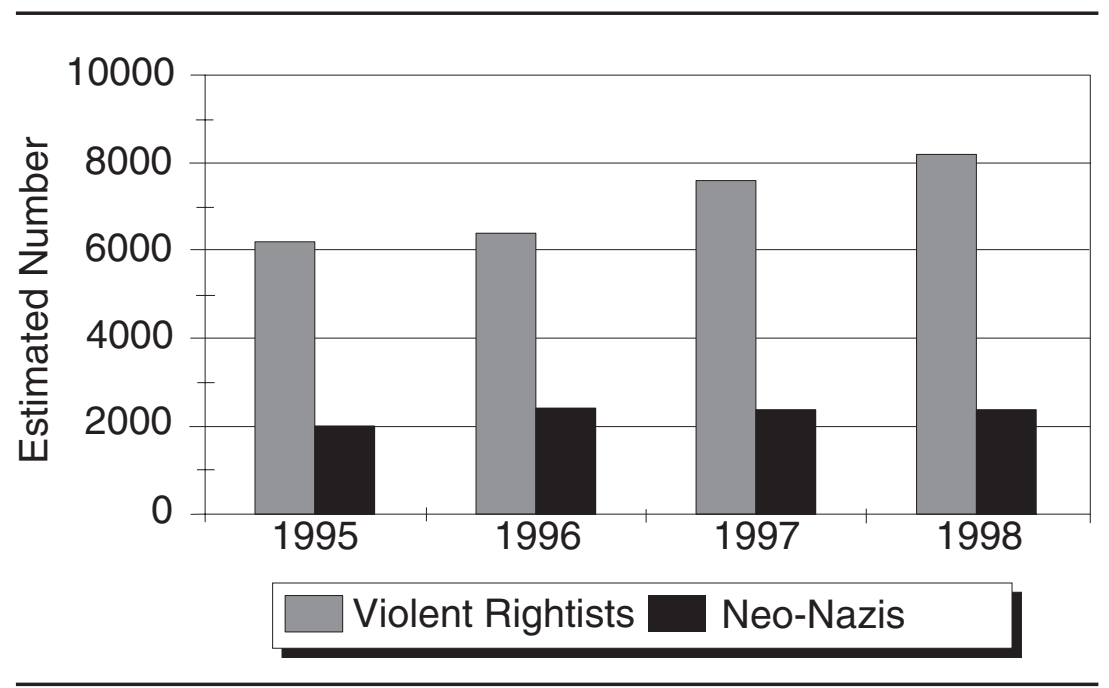

Figure 2: Trends in Right-Wing Potential

than the actual-rate of perpetration. In recent years, the number of violent offenses has declined somewhat (see Table 1).

\section{EVOLUTION AND CHANGE IN SKINHEAD CULTURE}

The skinhead scene actually consists of many scenes with elements borrowed from other subcultures. For this reason, it is impossible to speak of skinheads as if they all shared an identical culture, ideology, or organizational structure; there 
are also evolution and change in the scene. Three types of development are worth noting: The first is adaptation of the skinhead style to fit the local political culture. The second is in the increased networking of skinhead groups; this includes organization diffusion above the local level and reflects the internationalization of skinhead style. The third is in the commercialization and commodification of skinhead culture.

In the first development, the international skinhead style (much like other subcultural styles) can be "downloaded" from international media and adapted to fit local conditions. This produces variation not only in the groups themselves but in their local "partners." As local variations include cultural elements that respond to the particular culture and community, the network of potential supporters varies from one place to another. For example, in the United States, racist skinhead groups may be allied locally with neo-Nazi groups, with traditional organizations such as the Ku Klux Klan, or with such groups as Aryan Nations or the World Church of the Creator. In Germany, rightist skinheads may find political partners with neo-Nazi groups or with Kameradschaften and political "discussion groups." White supremacist groups (often imported from the United States) also have some appeal because they offer a racist model that is not associated with the Nazi era (thereby avoiding both the stigma of association with the Nazi period and reducing the likelihood of being banned or prosecuted).

This ideological and associational variation has counterparts in the United States, as in the example of the Nazi Low Riders of Antelope Valley, California. Although the name conjures up images of Los Angeles Latino subculture, this group combined elements of skinhead culture, Nazi ideology, racism, and a business sideline in the methamphetamine trade (Finnegan, 1997). Local variations such as these show that such subcultures are dynamic and difficult to capture in a simple ideological or political definition. Local scenes show a kind of cultural entrepreneurship that combines national and international models with the political culture of the local community.

There also appears to be a growing network of rightist culture on both the local and international levels. Though their impact is difficult to estimate, there is evidence from a number of sources that the right-wing elements of the skinhead scene have become more structured and that they have increased their capacity to cooperate with other groups. Those partner groups often provide the organizational structure, capacity for logistics, and tactical planning (e.g., for demonstrations) that skinheads have traditionally lacked. Most of all, those groups may provide ideological structure and tutelage.

The hard street-fighting style of many skins has long been used by other rightist groups for its intimidation value. According to former neo-Nazi Ingo Hasselbach (1996), "The skins were our storm troopers-the idiots who cleared the streets for us and intimidated our enemies-and enjoyed a bit of violence anytime" (p. 171). However, there is evidence that by the end of the decade skins had expanded beyond this role of "useful idiots" (Hasselbach's term) and that they had done it beyond national boundaries. In early 1999, skinheads from 
Croatia, Slovenia, and Germany joined neo-Nazis from Hungary and elsewhere for a demonstration in Budapest. Rightist skins were a common sight at Aryan Nation meetings in the United States, the White Aryan Resistance actively recruited violent skinheads in the early 1990s, and a well-known watchdog organization argues that the skinhead scene is moving "from chaos to conspiracy" (Southern Poverty Law Center, 1998, p. 23). In Germany, connections have developed between the skins and various neo-Nazi groups and, more recently, to rightist political parties; in particular, the National Democratic Party and its youth organization, the Young National Democrats, have actively sought contact and cooperation with right-wing skins (Bundesamt für Verfassungsschutz, 1998a, 1998b, 1998c).

If the actual extent of political networking is a bit difficult to estimate, the evidence for the international commercialization of skinhead culture seems more easily quantifiable. In Germany, data on this trend come from the fact that police and government agencies monitor both "hate speech" and material that is considered "harmful to youth." For example, music and public speech can be targeted for official repression if they are placed by authorities under either of these categories. Thus, in a 1993 operation that would seem unusual to citizens in the United States, German national and provincial agencies prosecuted rightist and "White power" skinhead bands and took legal action against commercial distributors of their music.

In a similar action in 1997, police and security agencies in 10 federal states searched the homes and places of business of 24 individual and corporate distributors of music judged to be racist. Confiscated in the action were several thousand CDs and various Nazi memorabilia and propaganda material. Also captured were computers, business files, and, in one case, an automatic weapon with ammunition (Landesamt für Verfassungsschutz, 1998).

Despite these periodic waves of concerted suppression and interdiction by authorities, the number of concerts and distributors of skinhead materials (and literature) increased steadily through the late 1990s (see Figure 3). The number of bands also increased, showing a 20\% surge in 1 year alone (from fewer than 80 in 1997 to roughly 100 in 1998). Repression efforts run up against two major obstacles. The first is the increase in commercialization and commodification, in which skinhead and racist culture is turned into products (e.g., music, clothes) and marketed for economic gain. This produces an economic incentive for the continuation and exploitation of skinhead and racist culture.

The second, interrelated, trend is the internationalization of that commercial culture that allows concerts and distributors to operate effectively from other countries. To escape German sanctions, bands, literature, and concerts are likely to appear in Denmark or Sweden (in fact, it was from Denmark that American neo-Nazi Gary Lauck was extradited to Germany in 1995). Of course, the United States is the prime international center for the distribution of skinhead, White power, and extremist material. The development of electronic networks such as the World Wide Web has promoted this globalization, increased the 


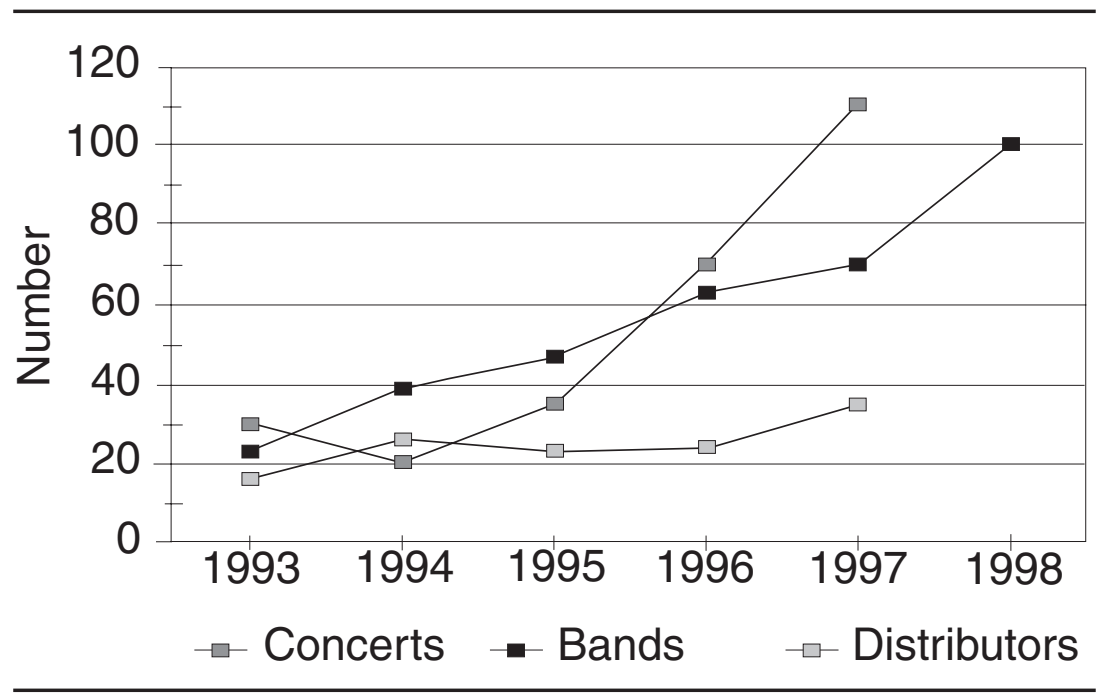

Figure 3: Trends in Skinhead Culture

commercial availability of rightist materials, and undermined German attempts to suppress skinhead culture. Ideological/commercial Web sites (usually based in the United States but reachable from virtually anywhere) have expanded; Web sites suppressed in Canada, Germany, and elsewhere reappear in the freer cyberspace of the United States where they exist alongside entrepreneurial American extremists.

\section{DISCUSSION}

Germans are not alone in the surge of xenophobia and hate crime. There are signs that similar developments are occurring throughout industrial societies undergoing modernization and structural change, stress in employment markets, and a significant influx of people perceived as foreign. Though these structural and social problems all affect Germany, they are common throughout contemporary democracies. So, too, is xenophobic violence and bias crime.

The preceding analysis dealt with rightist potential (and the role of skinheads within it) in one country. The German data are more complete than information available in other nations, but they are not identical with what would be categorized as hate- or bias-crime in the United States. Notably, offenses based on gender and sexual orientation are not included (as indeed they are not in a number of American states). These differences in emphasis make it difficult to compare trends across nations with accuracy. Even so, the data are helpful in pointing out some of the major trends in xenophobic culture in Germany and elsewhere. 
Some of our concerns go beyond what the data can clearly tell us. However, we can make some reasonably well-grounded speculations about the role of aggressive youth cultures in contemporary bias crime. I would like to suggest some propositions that seem sensible based in part on the analysis presented here. Each is supported to a greater or lesser extent by current information, but to have more certainty, more comparable data from other nations will be needed. Indeed, we will need far more systematic data for the many jurisdictions of the United States because, unlike Germany, reporting under U.S. hate crime legislation is voluntary and still far from being complete.

- First of all, youth cultures are often not just passing fads. The decline of the skinheads has long been predicted, but it has changed, expanded, and internationalized in the two or more decades since it first appeared. As a style, it has some ephemeral characteristics that will undoubtedly change further and even disappear. But, like rock and roll music (whose death has been predicted for four decades), there is no reason to doubt that this or a similar youth culture will continue to express some form of aggressive xenophobia.

- The early skinhead style originally emerged from British working-class culture as an expression of a strong, working-class masculinity. Segments of it later split into politicized left and right, with the racist segment emerging as an amalgam of aggressive masculinity and explicit xenophobia. This racist tendency was augmented by a sporadic, but growing, connection with ideological elements of the extreme and racist right. What resulted was a three-part poison of aggression, xenophobia, and ideology that has been much more self-sustaining than any of the individual components alone. Where younger persons, particularly males, are confronted with economic modernization and dislocation for which they are ill prepared, and where scapegoats in the form of various cultural "outsiders" are perceived as threats, this three-part poison will continue to produce aggressive subcultures (of which skinheads are only one contemporary variant).

- The skin/fascho scene has developed elements of a subculture that includes music, fanzines (fan magazines), concerts, and other more or less organized symbolic and cultural events. This helps provide an integration of the scene as well as a sense of identity — of being part of something much larger, more powerful, and even somewhat "dangerous." This provides the basis for a self-sustaining scene-it falls short of being a "movement," but it provides a network through which movement-like connections can develop.

- The skinhead scene has broken out of its parochial/provincial boundaries to establish important links to ideological groups-groups that provide the "intellectual" part of the fascho program, offer a "standing organization," and maintain a durable political opportunity structure. The skins might not be interested in organizing, say, a Rudolf Hess Memorial day (a German neo-Nazi tribute day, substituted for Hitler's birthday, which cannot be celebrated publicly); the neo-Nazis do that. But, the skins can show up, act badly, and lend a show of force and aggressive power. They typically horrify the orthodox rightists, but both groups gain from the odd alliance. Moreover, skinheads have graduated from being what Hasselbach (1996) called "useful idiots"; some have crossed the ideological line and become part of the organizational neo-Nazi right. They maintain links to the skin scene and provide a bridge from the rowdy skinhead style to the more disciplined structures on the right. 
- The scene of youthful xenophobic aggression has broken out of its provincialism to establish links to international groups. There are many reports of contacts to a variegated international network, particularly in the United States, United Kingdom, Scandinavia, the Netherlands, and to a lesser degree Spain (relations with the Czechs, Poles, Hungarians, and other central Europeans are somewhat more strained, but they exist). Explicitly racist groups such as Blood and Honour and the Hammerskin Nation provide an international style that is easily downloaded and adapted from the World Wide Web, music, and literature. In Germany, the government estimates that there are more than 200 skinhead or racist Web sites (in the United States, there are far more, of course); many of them are in English to broaden their impact (or because they use North American Internet providers to avoid German censorship).

- Concerts of White power bands are typically discouraged, even prosecuted, in Germany. Bands are raided, CDs confiscated, concerts broken up or forbidden, and leaders prosecuted under German hate speech laws that forbid glorification of Nazis, racist speech, or defamation of victims of the Holocaust. It is even illegal to deny that the Holocaust existed or to slander Jews in public speech. This suppression is undermined by global electronic networks and by support for the scene from abroad.

- The example of skinheads provides some insight into the dynamics of international commercialization - a phenomenon that appears to help stabilize the scene, allow it to expand, and give it a longer life than might have been expected. The same is true, but more so, for right-wing extremist groups and sentiment. This commercial dimension includes cultural artifacts, memorabilia, music, and literature that provide an economic incentive for widening and deepening the scene.

- The structural conditions that produced skinhead groups all over the world are still present. Where they are not solved, skinheads or some other subcultural phenomenon is likely to persist. Status anxiety, identity problems in declining workingclass culture, and the compensatory needs of underemployed or threatened young people, particularly males, are continuing problems. These problems, and the youth cultures they produced, extend well beyond the boundaries of the less advantaged. Although the expression of such xenophobia may have significant origins in threatened segments of the housing and labor markets, that xenophobia has been transported politically and culturally to a much broader segment of the population (e.g., middle-class youth, young women, and a variety of nations that have developed "copy-cat" scenes). ${ }^{4}$

- The psychological need for an identity and sense of meaning remains. Not all youth can answer that need with conventional achievement in work, education, and family, but some find it easier or more exciting to use physical and symbolic aggression against out-groups. This form of identity can be extremely unrealistic and dysfunctional (especially when based on a mythopoetic White race, or the like, which either does not exist or, if it does, hardly appoints these youth as its "sword and shield"). This is not a productive identity search, but it will continue to have power where other sources of positive identity are not available.

- Last, although racist skinheads and other aggressive cliques may seem atavistic, they may actually be on the cutting edge of modern xenophobia. Their spontaneous and unpredictable style was traditionally seen as a disadvantage, but a trend in the far right throughout the decade comes to favor this seemingly primitive form of action. Increased repression of extremist groups by various national governments has led to organizational innovations. In the United States, the concept of leaderless resistance sprang up on the far right to promote action that is not controlled by a specific organizational center. The concept was developed among 
American extremists to replace the standard organizational model that proved vulnerable to government infiltration and prosecution. But, small groups of aggressive youth had long been the source of spontaneous, "unorganized" violence. Skinheads and other aggressive subcultures are part of a fluid milieu that is held together by symbols, idea fragments, cultural events, and electronic media-but often without any classic organizational structure. This relatively unorganized base then provides a place from which the more ideological of them are likely to find their way into parties, movements, and discussion circles. Thus, the language and symbols may often sound like the "same old thing," but underlying the familiar slogans is a significant change - the right has modernized and adapted, and it has taken on a more youthful face than was the case a generation ago.

\section{NOTES}

1. The term xenophobia can refer to a generalized antipathy toward out-groups in general or toward a specific target group such as foreigners, Jews, homosexuals, and others. In German usage, the term Fremdenfeindlichkeit refers to antipathy against foreigners, although Xenophobie is increasingly used. I have tried elsewhere to make these distinctions somewhat more carefully. In this discussion, I try (without complete success) to use xenophobia when referring to the more inclusive concept. The terms antiforeigner and anti-Semitic not only denote the more specific antipathies, they also correspond to the primary categories in the official Germany agency reports.

2. This is not the place for an analysis of the causes and appeals of youthful xenophobia, but some useful starting points are Bergmann (1998); Boehnke, Hagan, and Hefler (1998); Hagan, Merkens, and Boehnke (1995); Oesterreich (1998); Watts (1997, 1999); Watts and Zinnecker (1998); and Willems (1995). For a closer look at the role of young females on the right, see Mushaben (1996).

3. Other discussions of aggressive German youth cultures in the early 1990s can be found in Watts, 1997 (particularly in chaps. 1, 6, 7, and 9). For a more detailed analysis of the shift in public opinion and violence during the 1980s and 1990s, see Watts, 1997 (particularly chap. 2). A detailed chronology of postunification xenophobia is provided by Rainer Erb (cited in Kurthen, Bergmann, \& Erb, 1997, pp. 263-285).

4. This conclusion obviously refers to the spread of aggressive youth culture, the primary topic of this discussion. I do not mean it to be a global proposition about the origins of xenophobia or to imply that youth are the source of xenophobia. What I have argued from the German data, though, is that xenophobic youth have been the primary source of rightist violence in the past decade.

\section{REFERENCES}

NOTE: Sources are provided in English wherever possible, though in many cases the data reported are available only in German. In those cases, I have provided a translation of the original title and institutional name (when a governmental agency is the data source). Readers interested in the extensive German literature on the subject might start with the bibliographies in Watts (1997) and in Kurthen, Bergmann, and Erb (1997).

Anti-Defamation League. (1995). The skinhead international: A worldwide survey of neo-Nazi skinheads. New York: Author.

Bergmann, W. (1998). Violence as social control: Right-wing youth in Germany. In M. W. Watts (Ed.), Cross-cultural perspectives on youth and violence (pp. 99-115). New York: JAI.

Boehnke, K., Hagan, J., \& Hefler, G. (1998). On the development of xenophobia in Germany: The adolescent years. Journal of Social Issues, 3, 585-602. 
Bundesamt für Verfassungsschutz [Federal Office for Protection of the Constitution]. (1996). Verfassungsschutzbericht [Online]. Retrieved August 15, 1998, from: http:// www.bundesregierung.de/02/0201/innen

Bundesamt für Verfassungsschutz [Federal Office for Protection of the Constitution]. (1997). Verfassungsschutzbericht [Online]. Retrieved August 15, 1998, from: http://www. bundesregierung.de/02/0201/innen

Bundesamt für Verfassungsschutz [Federal Office for Protection of the Constitution]. (1998a, March). Rechtsextremistische Skinheads. Entwicklung, Musik-Szene, Fanzines [Right-wing extremist skinheads: Development, music scenes, fanzines] [Online]. Retrieved November 1, 1998, from: http://www.verfassungsschutz.de

Bundesamt für Verfassungsschutz [Federal Office for Protection of the Constitution]. (1998b, July). Right-wing extremism in the Federal Republic of Germany: Situation report [Online]. Retrieved November 1, 1998, from: http//www.verfassungsschutz.de

Bundesamt für Verfassungsschutz [Federal Office for Protection of the Constitution]. (1998c March). Right-wing extremist activities in INTERNET [Online]. Retrieved November 1, 1998. from: http://www.verfassungsschutz.de

Bundesamt für Verfassungsschutz [Federal Office for Protection of the Constitution]. (1998d). Verfassungsschutzbericht [Online]. Retrieved August 15, 1998, from: http://www. bundesregierung.de/02/0201/innen

Finnegan, W. (1997, December 1). The unwanted. The New Yorker, 61-78.

Hagan, J., Merkens, H., \& Boehnke, K. (1995). Delinquency and disdain: Social capital and the control of right-wing extremism among East and West Berlin youth. American Journal of Sociology, $100,1028-1052$.

Hamm, M. (1993). American skinheads: The criminology and control of hate crime. Westport, CT: Praeger.

Hasselbach, I. (with Reiss, T.). (1996). Führer-ex: Memoirs of a former neo-Nazi. New York: Random House. (Portions excerpted in Hasselbach, I. [with Reiss, T.] (1996, January 6). How Nazis are made. The New Yorker, 36-57.

Heitmeyer, W., \& Müller, J. (1995). Fremdenfeindliche Gewalt junger Menschen. Biographische Hintergründe, soziale Situationskontexte und die Bedeutung strafrechtlicher Sanktionen [Antiforeigner violence of young people: Biographical background, social context and the significance of legal sanctions]. (1995). Bad Godesberg, Germany: Forum.

Kalinowsky, H. H. (1990). Rechtsextremismus und Strafrechtspflege. Eine Analyse von Strafverfahren wegen mutmaßlicher rechtsextremististischer Aktivitäten und Erscheinungen [Right-wing extremism and the law: An analysis of legal proceedings of suspected right-extremist activities] (3rd ed.). Bonn, Germany: Bundesministerium der Justiz.

Kurthen, H., Bergmann, W., \& Erb, R. (Eds.). (1997). Antisemitism and xenophobia in Germany after unification. New York: Oxford University Press.

Landesamt für Verfassungsschutz. (1998). Landesverfassungsschutzbericht (Report of the Provincial Office for Protection of the Constitution, Hamburg) [Online]. Retrieved March 29, 1999, from: http://www.hamburg.de/Behoerden/LfV/v-bericht

Levin, J., \& McDevitt, J. (1993). Hate crimes: The rising tide of bigotry and bloodshed. New York: Plenum.

Mushaben, J. M. (1996). The rise of femi-Nazis? Female participation in right-extremist movements in unified Germany. German Politics, 5, 240-261.

Oesterreich, D. (1998). Authoritarianism and aggression: German youth and right-wing extremism. In M. W. Watts (Ed.), Cross-cultural perspectives on youth and violence (pp. 39-51). New York: JAI.

Southern Poverty Law Center. (1998, Fall). Chaos to conspiracy: Racist skinhead violence growing more organized. Intelligence Report, pp. 23-24.

Watts, M. W. (1997). Xenophobia in united Germany: Generations, modernization, and ideology. New York: St. Martin's. 
Watts, M. W. (1999). Xenophobia among young Germans in the nineties. In S. Hübner-Funk \& M. du Bois-Reymond (Eds.), Intercultural reconstruction: Trends and challenges (pp. 117139). Berlin, Germany: Walter de Gruyter.

Watts, M. W., \& Zinnecker, J. (1998). Varieties of violence-proneness among male youth. In M. W. Watts (Ed.), Cross-cultural perspectives on youth and violence (pp. 117-145). New York: JAI.

Willems, H. (1995). Development, patterns and causes of violence against foreigners in Germany: Social and biographical characteristics of perpetrators and the process of escalation. Terrorism and Political Violence, 7, 162-181. 


\title{
The International Commission of Inquiry (Rwanda)
}

\author{
Lessons and Observations From the Field
}

ERIC G. BERMAN

Independent Consultant; International Commission of Inquiry

\begin{abstract}
The author served as the political affairs officer of the United Nations International Commission of Inquiry (ICOI) during its most recent tour (May through November 1998). (The political affairs officer is not responsible for the investigation's findings, which were the responsibility of the commission's chairman and members.) The author argues that to understand the work and findings of the commission, one must first place it within the broader context of the UN Security Council's failure to respond appropriately to the genocide in Rwanda. He concludes that despite appearances to the contrary, there was little enthusiasm to see ICOI succeed in fulfilling its mandate. The commission is another example of the unwillingness of the United Nations and the international community to take meaningful action toward Rwanda specifically and the Great Lakes region generally.
\end{abstract}

\section{BRIEF HISTORICAL AND POLITICAL BACKGROUND TO THE COMMISSION}

On April 6, 1994, the plane carrying the presidents of Rwanda and Burundi was shot down as it prepared to land in Kigali, the Rwandan capital. Within hours, a systematic series of killings had begun throughout the country. The targets of the attacks were moderate Hutus and all Tutsis. Within 3 months, the Rwandan Armed Forces (known by its French acronym FAR for Forces Armées Rwandaises and now called the ex-FAR) and the Rwandan militia (Interahamwe) murdered hundreds of thousands of people- the number is commonly put at upwards of 750,000 .

The carnage and mass slaughter were not a secret. A peacekeeping operation, the United Nations Assistance Mission for Rwanda (UNAMIR), had been deployed in Rwanda since the previous October. ${ }^{1}$ The international media also

Author's Note: This article is principally based on a presentation before the Geneva Forum, a seminar series devoted to contemporary arms control and disarmament issues, on December 7, 1998, and also a shorter version before the International Conference on Hate Crimes at the Brudnick Center on Violence and Conflict at Northeastern University in Boston on November 7, 1998.

AMERICAN BEHAVIORAL SCIENTIST, Vol. 45 No. 4, December 2001 616-625

(C) 2001 Sage Publications 
reported the unfolding atrocities authoritatively and graphically. Moreover, there are disturbing credible reports that the UN secretariat and some UN member states knew in advance-or should have known in advance — of the plans for genocide. $^{2}$

Leaving aside the thorny issue of whether the United Nations and the international community had prior knowledge of and could have prevented the genocide, how did the United Nations and the international community respond to it?

The UN Security Council eventually agreed to deploy a more robust force, but only after first reducing the number of Blue Helmets and without the means to implement its decision without a significant delay. It is telling that on April 21, two weeks after the bloodletting commenced, the council decided not to augment UNAMIR but rather to scale back the operation to a maximum of 270 peacekeepers ${ }^{3}$ - roughly $10 \%$ of its previously authorized strength. The diminished UN presence proved incapable of halting the killings, the enormity of

which was becoming increasingly visible and widely reported. As a result, the council was basically shamed into reversing its decision. On May 17, it chose instead to send a larger force-nearly twice the size of the initial UN mission. ${ }^{4}$ However, the council did so knowing that it would not be possible to implement its about-face decision for several months. (As an interim measure, on June 22, it authorized France to lead a multinational force, known as Operation Turquoise, for 2 months to provide humanitarian relief while the revamped UNAMIR worked to become operational. ${ }^{5}$ )

The resolution calling for a larger peacekeeping force also imposed an embargo on the sale and supply of arms and related matériel to the then government of Rwanda as well as to the Rwandan Patriotic Front (RPF), the rebel group fighting the government. Subsequently on August 16, 1995, ${ }^{6}$ the council decided to lift the sanctions against the new government of Rwanda (i.e., the ex-RPF), which had taken control of the country in July 1994. The embargo remains in effect against the ex-FAR and Interahamwe.

\section{THE COMMISSION'S CREATION AND FIRST TOUR}

Among persistent and credible reports that the embargo was not being respected, the council established the International Commission of Inquiry (ICOI) on September 7, 1995. ${ }^{7}$ For example, Human Rights Watch, a respected nongovernmental organization, accused France of rearming remnants of the former Rwanda government during Operation Turquoise (see, e.g., Human Rights Watch Arms Project, 1995). The commission was given the following mandate:

- to collect information and investigate reports relating to the sale or supply of arms and related matériel to former Rwandan government forces in the Great Lakes region in violation of council Resolutions 918 (1994), 997 (1995), and 1011 (1995); 
- to investigate allegations that such forces are receiving military training to destabilize Rwanda;

- to identify parties aiding and abetting the illegal acquisition of arms by former Rwandan government forces, contrary to the council's resolutions referred to above; and

- to recommend measures to end the illegal flow of arms in the subregion in violation of the council resolutions referred to above.

To carry out its investigation, the council recommended the commission be composed of 5 to 10 impartial and internationally respected persons including legal, military, and police experts under the chairmanship of an eminent person and assisted by appropriate support staff. The council also called on states, UN bodies, and others "as appropriate" to collate information in their possession relating to the mandate of the commission and make this information available. It also called on states to cooperate fully with the commission, including:

- guaranteeing freedom of access and movement (including border points, airfields, and refugee camps),

- providing information on request and access to relevant archives, and

- taking appropriate measures to ensure the commission members' safety and security.

The commission conducted its work from October 1995 through October 1996 and issued three reports. ${ }^{8}$ A fourth report, an addendum, was issued in January 1998. It was primarily a record of correspondence that had been received since the commission had submitted its last report.'

The commission was successful to a surprising degree in fulfilling its mandate. It was able to document in great detail a shipment of weapons from the Seychelles to the ex-FAR in contravention of the embargo. It was also able to document that the ex-FAR and Interahamwe were conducting military training with the intent of retaking Rwanda. The commission's success in uncovering these events was no doubt made easier by the fact that (a) the government of the Seychelles actively and enthusiastically cooperated with the commission and (b) the training being undertaken was an open secret, and in close proximity to refugee camps with large numbers of international humanitarian personnel milling around. The commission also brought to light many lesser or unknown facts such as the ex-FAR/Interahamwe's extensive fund-raising and recruitment activities in Kenya.

The significance of the commission's work can be gauged in part by the fact that the decision was taken not to issue the report (although it was quickly leaked). Concurrent with the commission's writing its findings was the advent of a rebellion in Zaire that, unknown at the time, would quickly succeed in ousting President Mobutu Sese Seko from power. One theory put forth to explain the decision not to make the ICOI report public was to refrain from giving Rwanda the pretext to invade Zaire and make an already volatile situation worse. A 
security council-mandated report concluding that Zaire was being used for (if not actually assisting in) the planned overthrow of the government of Rwanda would have provided Kigali with a casus belli (cause for war).

\section{THE COMMISSION'S REACTIVATION}

On April 9, 1998, the council reactivated the commission. ${ }^{10}$ Although much had changed in the region as concerned the activities and whereabouts of the ex-FAR and Interahamwe, ICOI's mandate was pretty much the same as in 1995 (with notable changes underlined):

- to collect information and investigate reports relating to the sale, supply, and shipment of arms and related materiel to former Rwandan government forces and militias in the Great Lakes region of central Africa, in violation of Security Council Resolutions 918 (1994), 997 (1995), and 1011 (1995);

- to identify parties aiding and abetting the illegal sale to or acquisition of arms by former Rwandan government forces and militias, contrary to the resolutions referred to above; and

- to make recommendations relating to the illegal flow of arms in the Great Lakes region.

Thus, ICOI's focus was narrowed in the sense that military training was not mentioned but expanded to include explicit reference to the militias (i.e., the Interahamwe). This change was more cosmetic and legalistic than substantive as the lack of explicit reference to the militias had not hindered the commission's previous investigation or reporting. As concerned the new wording of the request for recommendations, the commission interpreted it to mean that the council intended ICOI to undertake a broader investigation (a view not universally shared in the secretariat).

A much bigger difference concerned the commission's administration. In Resolution 1013, the council encouraged states to make voluntary contributions "to supplement" the UN Trust Fund for Rwanda to finance the commission's work. In Resolution 1161, however, the council encouraged states to make voluntary contributions "to provide" the financing for the UN Trust Fund for Rwanda for the work of the commission. As a result, ICOI could not spend money unless it was specifically earmarked for its work.

The commission reestablished its operations in Nairobi on May 13 after a week-long series of briefings at headquarters in New York. Over the next 6 months, the chairman, Ambassador Mahmoud Kassem of Egypt, and the three commission members visited nine other countries in the region (Burundi, Ethiopia, Mozambique, Rwanda, South Africa, Tanzania, Uganda, Zambia, and Zimbabwe), as well as two countries in Europe (Belgium and the United Kingdom). These countries were selected because the commission believed it could obtain useful information to further its investigation. A visit did not necessarily signify 
that the government was suspected of having violated the embargo. The chairman and members met with representatives of states and international and intergovernmental organizations, as well as members of civil society, including nongovernmental organizations, research institutes, and the media.

\section{THE COMMISSION'S FINDINGS AND RECOMMENDATIONS}

The commission had relatively little success in documenting arms sales in contravention of the embargo. The commission learned a lot about general trends but little about specific incidents that it could report. The region is awash in small arms-the area in the Democratic Republic of the Congo (DRC) that borders Rwanda and Uganda was described routinely as the "Wild West" or an "open arms bazaar." The commission was told of instances when chickens were being bartered for guns. Legal shipments of arms quickly found their way into rebel hands through government policy, corruption, or capture. The commission was told how a rebel group active in the region looked at arms sales to the government it was fighting with concern because of the increasing threat they posed-but not for the reasons one might at first expect. The rebels were concerned not so much that the weapons might be used against them but rather with the logistical and security problems they would encounter in trying to safely store the additional stocks of weapons that they assumed they would soon capture. The commission also learned that significant shipments of small arms were arriving in the region from eastern European surpluses, but it was not possible to ascertain that such shipments were going directly to the ex-FAR and Interahamwe in contravention of the embargo. Several interlocutors suggested that African arms manufacturers were also selling weapons and ammunition to rebel groups in the region because of economic necessity if not politics, but they could provide no proof and the commission had insufficient reason to visit any arms factories.

The commission had some success, however, in tracking the ex-FAR and the Interahamwe. This in itself was an accomplishment and a time-consuming exercise as little was known about their whereabouts after the rebellion in Zaire that led to Mobutu's overthrow. Whereas formed units of ex-FAR/Interahamwe had previously been located principally in eastern Zaire and western Tanzania, they had since scattered throughout the region. Those in eastern Zaire had fled from the advancing rebels that were supported by Rwanda and comprised significant numbers of Banyamulenge Zaireans. The Banyamulenge were seen as having ethnic ties to Tutsis and, therefore, had come under increasing attack by Hutus and other Zaireans sympathetic to the anti-Tutsi propaganda promulgated from the refugee camps as well as from Kinshasa. Retribution was exacted from the entire Rwandan Hutu refugee population without discretion. It is widely believed that many thousands of the Rwandans who had been living in the camps 
were killed. (Rwandan Hutu refugees in Tanzania, of whom there were fewer, were repatriated with little concern for their ability to be absorbed or for their eventual resettlement—as long as it was not in Tanzania.) The commission therefore believed that it had to ascertain where exactly the ex-FAR and Interahamwe were, and in what numbers, to better know where to track arms deliveries that were in violation of the embargo.

As a result of its independent research and information obtained from a couple of hundred interviews, the commission concluded that at the beginning of August 1998, some 50,000 ex-FAR and Interahamwe were located in sizable organized groups in nine countries. The countries were Angola (1,500); Burundi (500); the Central African Republic (2,000); Congo (Brazzaville) (5,000$7,000)$; the DRC (15,000); Rwanda (10,000-15,000); the Sudan $(5,000-8,000)$; Tanzania $(3,000-5,000)$; and Zambia $(2,000) .{ }^{11}$ These numbers should be taken as indicative and not authoritative. Although much anecdotal information was received ${ }^{12}$ the genocidaires' understandable interest in maintaining a low profile coupled with their intermingling with other rebel groups and ongoing recruitment made their enumeration extremely difficult. As concerned the location of the leadership, the commission believed that apart from those that had returned to northwest Rwanda, there were others who remained principally in West Africa, Kenya (although a 1997 crackdown by the Kenyan government had reduced Rwandan extremists' activities and fund-raising in Nairobi), and South Africa.

The commission also had some success in substantiating that the ex-FAR and Interahamwe had entered into alliances with other rebel movements throughout the region. ICOI heard credible reports that they were active with other rebels in Angola, Burundi, Congo (Brazzaville), the DRC, Tanzania, and Uganda. The commission received copies of written agreements between ex-FAR/ Interahamwe and Burundian rebel groups that it believed to be authentic ${ }^{13}$ and was told by sources rated reliable that written agreements had been concluded between ex-FAR/Interahamwe and the Ugandan Allied Democratic Forces. It was clear that in several instances the rebel groups shared resources and took part together in military operations. However, the outstanding question remained as to exactly how formal were these alliances: simple marriages of convenience or multilayered and long-term relationships? Most, it would appear, reflect the former category.

The commission concluded, therefore, that placing an embargo on only one rebel group was not going to stop that group from obtaining weapons from other rebel groups not under embargo. The commission recommended that the council consider rewording the current embargo that focuses on prohibiting arms sales that are intended for the ex-FAR/Interahamwe for use "within Rwanda." Having said this, the commission was not so naive as to believe that the embargo was being violated because such a loophole existed or that the placement of additional rebel groups under embargoes would in themselves solve the problem. 
The commission noted that none of its recommendations from 1996 had been implemented and, therefore, limited its recommendations. It recognized that without political will on the part of the region's governments and of the international community, technical measures would be largely ineffective. The commission commended South Africa for its efforts to combat the trade in illegal arms, such as by reducing the number of international airports and creating national legislation aimed to strengthen the government's control over arms shipments and the supply of military training. Although the efficacy of these policies would not be known for some time, Pretoria's approach to the problem of illicit arms transfers contrasted sharply with that of many other countries, which believed (incorrectly) either that no problem existed or that their efforts to deal with the problem were sufficient.

\section{LESSONS AND OBSERVATIONS FROM THE FIELD}

Even in the best of circumstances, tasking a four-person team to conduct a 6-month investigation into such a complex and murky matter as illegal arms shipments to the ex-FAR and Interahamwe was extremely optimistic. Six months was barely sufficient time to establish sources and arrange the requisite visits, let alone digest the information obtained. But, the commission was forced to work under difficult conditions-some of them avoidable.

The total reliance on the Voluntary Trust Fund was problematic. Nine countries did pledge U.S. $\$ 700,000$ to the trust fund. ${ }^{14}$ Although additional funds might have enabled the commission to undertake a fuller investigation and visit more countries, the greater issue was the significant lag time between countries' pledges and disbursements. The commission could not spend money until it had been actually deposited in its account. The commission wasted an inordinate amount of time waiting for appropriate office equipment because of lack of funds on hand. Bureaucratic squabbles between New York and the UN Office at Nairobi-in large part due to financing questions-resulted in much unnecessary and unproductive tension and misunderstandings.

Granted, the rebellion in DRC that began on August 2, 1998, greatly complicated the commission's work. A trip to Kinshasa that was potentially of critical importance given the reported activities of the Interahamwe and ex-FAR in that country appeared to be imminent. (A lot of effort had been put into making the visit a reality given the tense relations that developed between the United Nations and the DRC during the UN investigation into allegations of massacres of Rwandan refugees.) The rebellion made it impossible to visit Kinshasa, and efforts to meet President Laurent Kabila in Lubumbashi proved unworkable. Also, the attention of Kampala and Kigali lay in events unfolding in their western neighbor and not with an investigation - the effects of which were questionable. The commission managed only one more visit to Rwanda after August 2 and did not return to Uganda. A diplomat from a country in the region, who was 
reported to be highly reliable and to possess information of direct concern to the commission's mandate, had prior to August 2 indicated to the chairman his willingness to assist ICOI completely. However, when the commission met with the diplomat some weeks after the rebellion had commenced, the chairman found his interlocutor formal and reserved. Nothing of substance was gleaned from the meeting. That country's policy toward various players in the region had obviously changed dramatically.

The commission faced numerous obstacles that called into question the seriousness with which the Security Council, the international community, and regional governments viewed the commission's work. Despite the Security Council's admonitions for states and UN bodies to cooperate, they rarely did so enthusiastically and without much delay.

It was interesting how "popular" the commission became the closer the date approached when it would have to leave Nairobi for New York. For example, on May 22, 1998, the Kenyan foreign minister met with the chairman and agreed to appoint a liaison officer to assist the commission in setting up interviews and meetings with government officials and agencies. This was done on September 30. One government responded to the chairman's request in June that an official visit be scheduled sometime before the commission had to return to New York in mid-November with the news that the end of November was a good time for the commission to visit the country! A more effective tactic was to express the government's strong desire to assist the commission and then explain that the proposed dates were not convenient as the foreign minister would be either away on official business or just returning from, or leaving for, official business. Once governments felt the commission would not be able to carry out its work fully because of time constraints, they became increasingly accessible and welcoming. States did not want to be seen as having failed to assist ICOI but did not want ICOI to ask too many questions or have access to too many people or places. By granting a meeting toward the end of the commission's mandate, they could maintain that they had indeed cooperated and would have been pleased to assist the commission further if only the chairman and members had not had to depart the region for headquarters so soon to issue its report.

The same is true not just for member states but for UN bodies. Whereas many individuals from the UN High Commissioner for Refugees (UNHCR) were helpful, there was a general reluctance to be expansive and as detailed as possible. This is perhaps understandable given that UNHCR staff members must work in difficult circumstances and would not necessarily be enthusiastic about exposing activities such as recruitment, training, and arming of rebels in and around refugee camps. Nevertheless, the commission certainly found curious the numerous reports of "refugees" fleeing the relative safety and comfort of refugee camps and towns in neighboring countries and choosing to return to DRC to rejoin the conflict. The conventional wisdom has always been that refugees tend to flee from conflicts. This suggested that UN officials from UNHCR and other agencies that worked closely in assisting UNHCR in running the camps 
would possess information that might have been extremely useful to the commission given its mandate. Unfortunately, obtaining information relevant to the commission's mandate was difficult.

Although the ICOI was not able to identify the specific nature of, and players involved in, arming the ex-FAR and Interahamwe in contravention of the UN embargo, it successfully highlighted that these two groups responsible for the 1994 genocide largely remain a cohesive and destabilizing force. The attitude and predisposition of the Security Council, the international community, and countries in the region toward the commission are equally troubling. Their repeated failures to respond with alacrity and appropriate resolve suggest that a similar tragedy in Rwanda and the Great Lakes region will elicit a similarly tepid response to that which has characterized the limited and delayed undertakings of the ICOI.

\section{NOTES}

1. The Security Council authorized the United Nations Assistance Mission for Rwanda (UNAMIR) on October 5, 1993. See UN Document S/RES/872 (1993, October 5).

2. The journalist Philip Gourevitch has been a particularly forceful proponent of this view and has reported that the UNAMIR force commander, Canadian Maj-Gen. Roméo Dallaire, provided the under-secretary-general for peacekeeping operations, Kofi Annan, with an account of the plans for extermination from a well-placed Hutu source he believed to be credible. (See, for example, Gourevitch, 1998, pp. 103-107.) Kofi Annan, UN secretary-general, proposed that the matter be investigated, which the Security Council accepted. A full report was made public in 2000.

3. See UN Document S/RES/912 (1994, April 21).

4. See UN Document S/RES/918 (1994, May 17).

5. See UN Document S/RES/929 (1994, June 22).

6. See UN Document S/RES/1011 (1995, August 16).

7. See UN Document S/RES/1013 (1995, September 7).

8. See UN Documents S/1996/67 (1996, January 26), S/1996/195 (1996, March 14), and S/ 1997/1010 (1997, December 24).

9. See UN Document S/1998/63 (1998, January 26). The International Commission of Inquiry had submitted its final report more than a year before it was published.

10. See UN Document S/RES/1161 (1998, April 9).

11. See UN Document S/1998/1096, Annex.

12. For example, one person with considerable experience in the region said the way to distinguish between members of the former Zairean army (ex-FAZ for Forces Armées Zairoises) and exForces Armées Rwendaises/Interahamwe, who often congregated together in the northeastern Democratic Republic of the Congo, was only during combat. Those who ran away from the fighting were ex-FAZ.

13. See S/1998/777, Annex.

14. The commission received $\$ 700,000$ in new pledges: Belgium $(\$ 100,000)$, France $(\$ 40,000)$, Germany $(\$ 50,000)$, Japan $(\$ 40,000)$, the Netherlands $(\$ 70,000)$, Norway $(\$ 90,000)$, Sweden $(\$ 50,000)$, the United Kingdom $(\$ 160,000)$, and the United States $(\$ 100,000)$. These anticipated contributions supplemented $\$ 100,000$ already in the trust fund from a donation Belgium had made in 1995. See UN Document S/1998/777 (1998, August 19, paragraph 60) and UN Document S/1998/ 1096 (1998, November 18, paragraph 6). 


\section{REFERENCES}

Gourevitch, P. (1998). We wish to inform you that tomorrow we will be killed with our families: Stories from Rwanda. New York: Farrar, Straus and Giroux.

Rwanda/Zaire: Rearming with impunity, international support for the perpetrators of the Rwandan genocide. (1995, May). Human Rights Watch Arms Project, 7(4). 


\title{
Hate Crimes Hurt More
}

\author{
PAUL IGANSKI \\ University of Essex, United Kingdom
}

\begin{abstract}
Constitutional questions about hate crime laws in the United States were settled in the early 1990s. Yet, critics persist in arguing that the laws punish "improper thinking." In this context, this article addresses the question of the justification of punishing motivation-or bias - behind hate crimes when the type of expression and the thought behind it used to indicate motivation are largely protected. There has been considerable legal scholarship on this question but little empirical investigation of how supporters of legislation respond to the question. The article draws from in-depth interviews carried out with a purposive sample of "elite" informants in Boston, Massachusetts, in 1999. A key theme that emerged was that alleged greater harms inflicted by hate crimes-over and above the harms inflicted by the same underlying but otherwise motivated crimes-justify greater punishment. A conceptualization is provided of alleged harms involved.
\end{abstract}

\section{THE CONTROVERSY OF "HATE CRIME" LAWS}

A significant policy response to racist incidents in the United States has been the enactment of laws providing extra punishment for crimes with a racial element than for the same underlying offenses without the racial context. A wide variety of other policy measures has also been established, but laws against "hate crimes" or "bias crimes," as they are called, have generated the most controversy.

Hate crime statutes with provisions for penalty enhancement enacted by most states - and with many covering religion, sexual orientation, and gender (AntiDefamation League, 1998, pp. 20-21) — have been subject to a fiercely contested debate about whether they are both desirable and constitutional. Despite the U.S. Supreme Court deciding on the constitutional concerns in 1993 (Wiscon$\sin$ v. Mitchell, 1993a), opposition continues to surface, especially in the news media (cf. Jacoby, 1998a, 1998b). Journalistic commentary has drawn considerably from academic debate. Primarily legal scholars have set the terms of the debate, and it is now polarized between the advocates (cf. Lawrence, 1999; B. Levin, 1998) and opponents (cf. Jacobs \& Potter, 1998) of legislation.

Controversy has centered on the alleged restriction by hate crime laws of a fundamental human "right." Critics argue that the additional punishment of crimes with a bias covered by hate crime laws amounts to the punishment of

AMERICAN BEHAVIORAL SCIENTIST, Vol. 45 No. 4, December 2001 626-638

(C) 2001 Sage Publications 
ideas (Gey, 1997), “improper thinking," and "extra punishment for values, thoughts, and opinions which the government deems abhorrent" (Jacobs \& Potter, 1997, p. 10). Opponents of legislation raise the prospect of the "slipperyslope" in that "if the government can enhance penalties for bigoted motives, it can enhance penalties for any disfavored motive" (Adelman \& Moorshead, 1995, p. 21). Such opposition is rooted in the commitment to freedom of speech guaranteed by the First Amendment to the Constitution, and about freedom of the thought_-or opinion - that lies behind speech and other expression.

Bigoted speech, and the thoughts behind it, provides the main indicator of motivation or bias behind hate crimes. However, without a predicate-or underlying-offense, such speech is generally protected in the United States. There also appears to be considerable public support for such protection. Recent analysis of data from the General Social Survey revealed that a majority of respondents-including Black respondents-were opposed to prohibitions against racist speech (Gross \& Kinder, 1998).

In this context, this article addresses the question of the justification and logic of punishing motivation-or bias-behind hate crimes when the type of speech indicating bias is largely protected. Although there has been some significant legal scholarship on this question, there has been little empirical investigation.

The article provides a development of earlier work on the desirability of hate crime laws by providing empirical material to inform normative judgments about legislation. It draws from part of a research program that involved a pilot project consisting of a series of in-depth interviews with "elite" informants (Marshall \& Rossman, 1999, p. 113) carried out in Boston, Massachusetts, in the spring and winter $1999 .{ }^{1}$ Massachusetts has some of the most comprehensive hate crime laws in the United States, and it therefore provides a useful case for policy learning. Focusing on Boston is particularly instructive, for as one of the respondents said, the legislation "was passed state wide, but it was to deal with a problem in the city of Boston" (R13). ${ }^{2}$

The aim of the pilot was to test out the feasibility of an investigation of the perceived value of hate crime legislation among the key communities with a stake in the debate about legislation. They included minority communities commonly targeted by hate crimes: law enforcement agencies, prosecutors, victim support agencies, media commentators, and academic commentators. ${ }^{3}$ The research used sociological tools - qualitative data collection and analysis- to

inform debate on normative questions that have a fundamental significance for policy intervention against hate crimes.

\section{THE CASE FOR PUNISHING HATE: GREATER HARM}

A common view among respondents in the Boston pilot was that hate crimes are distinct from the same underlying crimes without a bias motivation because 
they inflict greater harms. This view provided the dominant justification for the extra punishment attached to hate crimes. There is a only a small amount of empirical work indicating the harms generated by hate crimes. In this context, it is instructive to conceptualize the harms suggested by respondents in the Boston pilot, as they provide the core of their justification for hate crime laws, and provide the initial step in the logic of their argument. We might think of the harms generated by hate crimes as waves of harm that spread well beyond the individual victim (see Figure 1), and consequently, the targeted individual may be regarded as only the initial victim.

\section{THE INITIAL VICTIM}

For the victimized individual, there are arguably distinct psychological and emotional harms, which have been captured in a limited literature (cf. Garnets, Herek, \& Levy, 1992; Lawrence, 1999, pp. 29-44; Virdee, 1997), although the harms have also been disputed in the literature (Jacobs \& Potter, 1998). Some of the respondents in the Boston pilot discussed their views of the harms involved for the individual:

It scars the victim far more deeply. It is much more difficult I think as a victim to say I was put in the hospital because I'm gay or because I'm Hispanic, or because I'm a woman, than it is to say, you know I was walking down the street and I had my bag around my arm and some guy snatched from me, some guy knocked me over the head and took what I had, because they want property. You're not being singled out. You are beaten or hurt because of who you are. It is a direct and deliberate and focused crime and it is a violation of really a person's essence, a person's soul, because ... you can't change who you. ... And it's much more difficult to deal with. ... Because what a hate crime says to a victim of hate crime is "you're not fit to live in this society with me. I don't believe that you have the same rights as I do. I believe that you are second to me. I am superior to you." (R6)

In many occasions victims are more damaged than equal crimes.... Why, because there is no way that someone can no longer be Black, and therefore protect themselves from the vulnerability that lead to their prior attack. And generally hate crimes are for a characteristic that someone can't change. If someone's being robbed because they wear a lot of jewelry, then they have the ability to hide their jewelry or not, wear it in a particular area, and therefore feel less vulnerable to robbery. That is not true for people, at least in terms of how they internalize it I believe, the sense of being a victim of a hate crime. (R8)

I think that one of the thoughts behind hate crime legislation is that the attack or the crime inflicts unique psychological trauma on the victim ... that's going to inflict a unique trauma on me because if I were just attacked for whatever reason that's upsetting, that's horrible. But now I know I was targeted and I was chosen for something about myself that I can't change, that is at the core of my being, that I wouldn't want to change, that is unique to who I am. (R7) 


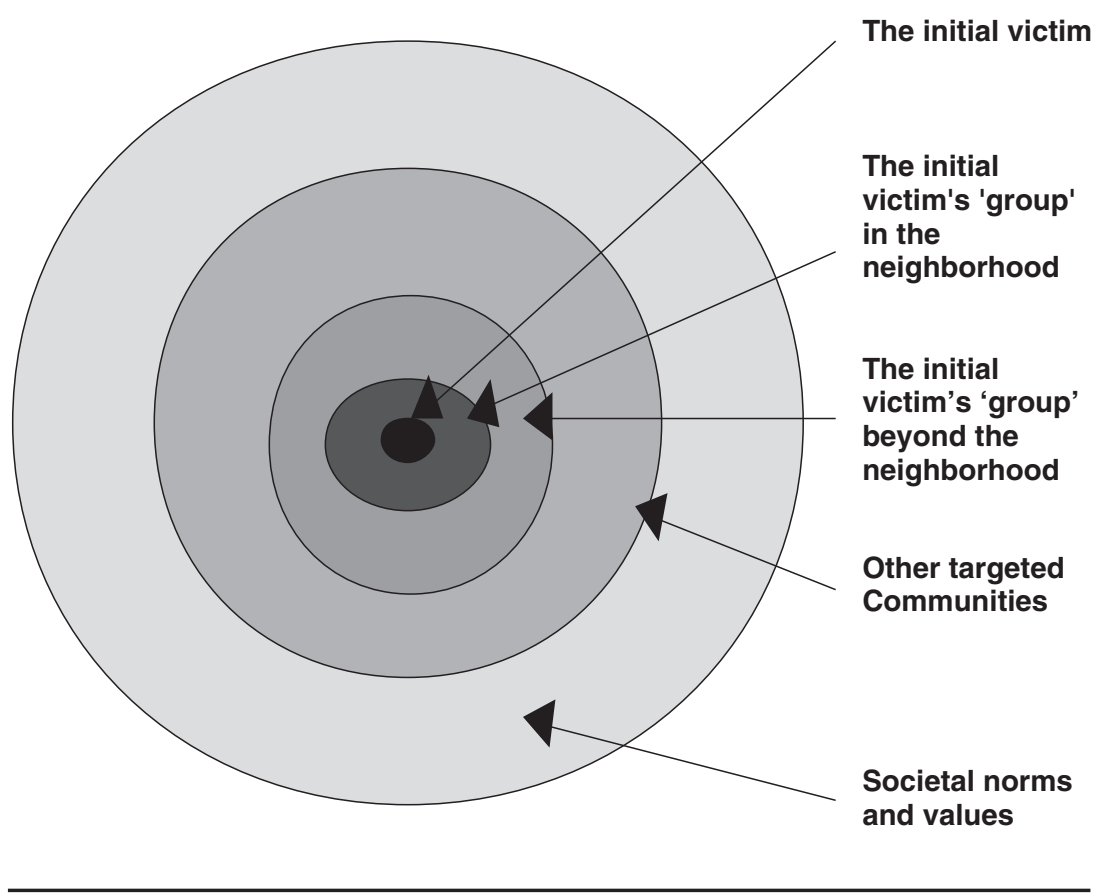

Figure 1: Waves of Harm Generated by Hate Crimes

Not all individual victims are going to experience the harms in the same way. Victims of hate crimes targeted because of their sexual orientation arguably experience unique conflicts (Garnets et al., 1992):

Often times it affects how they view their sexual orientation, and how they view themselves as a result of their sexual orientation. So for somebody who is very comfortable with their sexuality prior to an attack or prior to an incident, this often times challenges that, and they think, "Wow something that I was comfortable with and happy with, something that was a source of so much pride and joy and love for me, is now what caused me to be attacked, and I don't understand that." Or for example, somebody who is not really comfortable with their sexuality and who is attacked because of that, it completely shatters them, and often times sends them back into the closet, and that kind of leads to more psychological effects. (R7)

\section{THE INITIAL VICTIM'S GROUP IN THE NEIGHBORHOOD}

The harms generated by hate crimes spread beyond the individual to the initial victim's "group" or community in the wider neighborhood community who know the victim or hear of his or her experience. 
There are people out there who say an assault is an assault, a murder is a murder, a robbery is a robbery. But those crimes, as awful as sometimes they can be ... these hate crimes they take it one step further. They take that robbery one step further, and it just juts out throughout the community. It's not just one simple thing that's done and gone. It stays, it lingers and has potential to cause all kinds of problems which come back and haunt the whole community, the whole neighborhood. ... The enhanced penalty speaks to the damage that these types of crimes have the potential of doing. It's not just a crime that's done and gone. (R5)

The potential for hate crimes to provoke retaliation and communal tension has been clearly demonstrated in the United States. Respondents discussed the processes involved:

It tends to get people really anxious and excited and ... we like to call them domestic terrorism because with the attack on one person often times people retaliate against that, people of that group retaliate. So it's not just one crime. You've got the potential for many other crimes, like a ripple effect that's out there. (R5)

A single case can polarize a community. It sometimes causes retaliation by the victim's group against a member of the perpetrator's group that is completely innocent and disconnected. The reason is because hate crimes are viewed as message crimes, and so the victim group is sending back a message to the perpetrator group "we're not going to stand for this"; "you're going to suffer as we are." It is true, that for example, if a woman is being raped in a community, or there are these rapes of people walking in the park, that everyone feels a sense of nervousness. But I don't think that that kind of situation causes intergroup tensions, or polarization so that you have the polarization of various ethnic or racial or religious groups in a community as a result of the kind of incidents that you're talking about. So I think that there is a very clear distinction in terms of the potential consequences on a community level and often even broader than the individual community. (R8)

\section{THE INITIAL VICTIM'S GROUP \\ BEYOND THE NEIGHBORHOOD}

Other persons who share the victim's characteristics - and come to hear of the victim's plight - may potentially be affected by a hate crime. ${ }^{4}$ They may respond as if they have been victimized themselves. Some of the respondents indicated how hate crimes therefore constitute "message crimes":

If I walk out of ... [here] . . . and somebody jumps me and beats me up and while they're beating me up they're calling me a faggot, and they say, "We saw you come out of ... [there] ... we know what you are." First of all, that's certainly going to victimize me and my friends and my family. But for people who read about that and hear about that who are gay it's going to send them a clear message that that could have been them. Because I was targeted not because of my wallet necessarily but because they thought I was gay. So that could tell them that they're a potential victim. (R7) 
If there's a couple of African Americans who live in a White neighborhood, and there's a bias crime committed against one African American, the perpetrator is trying to send a message to all African Americans. (R3)

These crimes are also far more damaging to the community because you are not just targeting one person, you are targeting every other person within that victim's group. (R5)

I think there is a special consequence to the victim's group. . . . I think that they respond in many times as if they've been victimized, because they share the same characteristic as that person. They take it personally. (R8)

Particular cases of hate crimes given a high profile by the news media can have potentially far-reaching effects.

When Matthew Shepard was murdered we got a lot of calls that week from people in Boston who were saying, "You know I've read about this murder, I've been following it on TV and it scares me, I've been physically sick. I'm afraid to leave my house." So we've had people who were really exhibiting acute reactions to trauma and they were secondary victims. They weren't the primary victim. But because Matthew Shepard was targeted because he was gay it sent a clear message to individuals half-way across our country that it could be them. It affected them very intensely. (R7)

The Matthew Shepard case, or the James Byrd case, can in fact affect racial relations in this country for example well beyond Jasper, Texas, and I believe it has. And I think that's why it is special and it's different. (R8)

\section{OTHER TARGETED COMMUNITIES}

In addition to the impact on the victim's group, the wave of harm generated by hate crimes can spread to other targeted groups within and beyond the victim's neighborhood. As suggested by one respondent,

Even though you have one person that's targeted ... this stuff really incites a lot of tension and people get really crazy. And even if you have, let's say, an African American person that is targeted in the community who is to say, you know it is sending out a message to that person as well as everyone else in his group, "You're not wanted here." But who's to say that people from another group, let's say Asians or Hispanics, or gays, or anyone, could say, "Well Jeez if it could happen to him because of who he is who's to say that it can't happen to me." (R5)

\section{SOCIETAL NORMS AND VALUES}

For some respondents, hate crimes strike at the core of societal values, offending the collective moral code: 
While all crime may be offensive in a democratic society you do sort of expect that people who want money and don't have money may knock you over the head and take your wallet, and that robbery is their motive. And as undesirable as that motive might be it is somehow more odious to harm someone for no other reason than because of who they are, not because they have something that you want, that would be bad enough. But to harm someone or hurt someone because of who they are, and it recognizes both the fact that that kind of racially motivated hatred or bias-motivated hatred is offensive to society. (R6)

It's our diversity that makes us so great, and again, for somebody to threaten somebody or act and hurt somebody based on their difference, I think it's just outrageous. It really rips at what this country was founded on and I think it really ... it polarizes communities, it pulls us apart. (R5)

\section{THE CHALLENGE OF RIGHTS TO FREEDOM OF EXPRESSION}

The apparent harms inflicted by hate crimes appear to provide a compelling justification for the punishment of bias motivation behind crimes. However, such a justification would arguably be defeated by the stronger claim to freedom of expression if - as opponents of legislation suggest—hate crime laws punish expression and the thoughts and ideas behind it.

Against this claim, however, it may be argued that rather than punishing expression, in the punishment of hate crimes the laws use motivation, generally indicated by speech, as an indicator of the particular act committed. The motivation itself is not punished. This approach was suggested by a number of respondents as they reconciled hate crime legislation with a defense of freedom of expression:

My view is you are entitled to be a racist ... as long as you don't interfere in somebody else's ability to have access to various things. ... . We have a First Amendment, that's one of the great things about the country. . . . On the other hand ... you're not penalizing somebody because of their words, their thoughts. You're punishing them because of what they did.... They assaulted you ... and we enhance that because as they did that their words indicated an intent to do more. (R1)

In my opinion what's being punished in a hate crime is the action. Now there's a totally different, if I want to stand on a street corner and say I hate all Jews, under American law that is perfectly legal. If I stand on a street corner and I say I hate ... because he's Jewish, and then I hit him, that deserves an enhanced penalty. And that is a hate crime. So I do . . . so I draw the distinction, and I would say that we are not punishing the thought, we're punishing the action. (R3)

And I don't think that we are punishing the thought so much as we are punishing the act that flows from the thought. We are using the thought to show what motivated the crime. ... You said while you approached the person, "I'm gonna kill 
you, you faggot," that tells us that you intended to hurt this person because of who they are or of who you perceived them to be. (R6)

It's not at all penalizing thought or ideas, it's penalizing behavior. So you can think whatever you want to think about me, just don't beat me. And the reason that you beat me is because you don't like me because I'm gay. It has nothing else to do with that. Obviously it's very clear that that's what's happened. "You can think what you want. You can even call me a faggot when I'm walking down the street. But don't you dare touch me because I'm a faggot." (R7)

You can have that thought. You can express that thought. But you cannot act in furtherance of that thought, and we are punishing the act. How we know why you did what you did, you told us, you said. (R8)

It follows from accepting the legitimacy of using motivation as an indicator of the particular crime that the crime committed is qualitatively different from the same act without the same motivation. As discussed above, respondents believed that hate crimes are distinct from the same underlying crime because of the greater harms they inflict. Although it may be undesirable-and unconstitutional in the United States - to impose extra punishment for particular thoughts and speech, greater punishment for greater harm does not infringe on rights to freedom of speech and freedom of thought. The punishment is awarded for the harm inflicted, not for the motivation behind the conduct that inflicts the harm. Motive is only relevant to determine whether the particular act committed is a type of act-bias-motivated crime - that inflicts greater harms than the type of actthe same conduct without a bias motivation - that causes lesser harms. Punishment of the greater harm involved in hate crimes was accepted by Chief Justice Rehnquist, writing for the majority in Wisconsin v. Mitchell (1993b), the landmark case that settled the constitutional challenge against hate crime legislation. ${ }^{5}$

There are still a number of difficulties, though, with this position. If it is accepted that extra punishment of hate crimes is justified by the harms they inflict, it could be questioned whether the harms are primarily a reaction to the ideas attached to the underlying offense (Gey, 1997, pp. 1043-1050), or do the harms involve something else? If the harms associated with hate crimes are mostly reactions to the ideas behind them-in other words, offense or dislike of the ideas - the extra punishment would indeed arguably constitute the punishment of those ideas. This view was taken by one of the respondents:

I think that it may be true in some cases that a racially or ethnically motivated attack offends or hurts members of a community or a subset of the population in a way that a quote-unquote ordinary attack wouldn't do, but I'm not sure that that should make a difference. In fact I'm sure that it shouldn't make a difference to the criminal justice system. ... I find it offensive to say that if you have two victims of a crime, two people who have been beaten bloody, two people who have been assaulted, two people who have been murdered, to say that what was done to one person is worse than what was done to the other because of what was in the mind of the criminal who assaulted the first person, is a terrible injustice. . . Look at two 
victims lying on the ground and bleeding from their wounds and tell one of them we the government will take your wounds more seriously than his, I find very offensive. (R1)

The same respondent used the example of Holocaust denial to illustrate their defense of freedom of expression that provides the basis of their opposition to extra punishment for hate crimes:

\begin{abstract}
There's a good illustration. ... My father is a survivor of the Holocaust, he and his family were in Auschwitz. They were all wiped out, he barely survived, he was on death marches and so forth and so on. If anybody is going to be sensitive to questions of Holocaust denial I would be certainly among them. I find it unbelievably hurtful when someone starts to claim this is all a myth, it's Zionist propaganda or whatever. But the fact that I find it hurtful in my view doesn't take away the individual's right to say it. As we say in America, it's a free country. You are free to say what you like. You know there are certain categories of speech that have always been illegal, slander, liable, and fraud, and so on. But if somebody wants to get up and say "Hitler was great man and the Jews deserved it" or "It's all Zionist propaganda and there never was a Holocaust," as much as I might be offended and pained to hear those views I would be even more offended and pained to think that my government would start punishing somebody for what he said or what he believed, and I take exactly that point of view and apply it to this question of hate crimes legislation. It's not enough of a reason to invoke the punitive arm of the state to say that a group of people find something painful. In a free society there will always be tensions, that's part of what freedom entails. (R1)
\end{abstract}

\title{
HOW DO HATE CRIMES HURT MORE?
}

One prominent commentator on hate crime laws has recently argued that "hate crimes should be demonstrated to be distinct and more severe than other offenses to warrant differential punishment" (B. Levin, 1999, p. 8). This can be extended by arguing that for differential punishment to be justified, it has to be demonstrated that the greater severity of hate crimes is manifest in ways beyond offense or dislike of the "hate" behind them.

There has been a great deal of speculation about what the harms might be but relatively little empirical investigation. And, not all of the alleged harms provide a justification for the additional punishment of a class of crimes. For instance, it has been observed that hate crimes are more likely to involve "excessive violence" (B. Levin, 1999, p. 15); cause injury; lead to hospitalization; and involve multiple offenders, serial attacks, and repeat victimization of the same targets than criminal assaults in general (B. Levin, 1999, p. 15; J. Levin \& McDevitt, 1993). Although these harms would obviously merit more severe penalties in the specific cases to which they apply, none of them arguably provides a justification for the creation of a category of punishment above and beyond the circumstances of the particular crime. One example may illustrate the point. There would be no logical justification for punishing a perpetrator of a hate crime who 
acted alone just as severely as a perpetrator who acted in concert with others, solely on the basis that hate crimes on average are more likely to be committed by groups of offenders than is the case for the underlying crime without a bias motivation.

Arguably, the distinctiveness of hate crimes is not about the severity of the injury sustained by the individual victim. It is instead about the injuries inflicted over and above the circumstances of any particular crime. At least two interrelated types of injury may fit the bill: psychic injury and the in terrorem effect of hate crimes. These injuries were particularly singled out by Chief Justice Rehnquist in Wisconsin v. Mitchell. ${ }^{6}$

To take the first type of injury, to justify the establishment of hate crimes as a separate class of crimes deserving of greater punishment, it needs to be demonstrated that hate crimes usually cause psychic injury to victims irrespective of the particular circumstances of the incident in question. There has been some research on the psychological and emotional impact of hate crimes, which indicates the effects on particular victims (cf. Herek, Gillis, Cogan, \& Glunt, 1997). But, some of the findings are equivocal (cf. Barnes \& Ephross, 1994; Craig, 1999), and as a body of evidence not all of the findings to date conclusively demonstrate a distinct class of psychic injury associated with hate crimes. In addition, we might also expect the psychic injuries to be mediated by the group experience of the group to which the victim belongs.

To take the second type of injury that appears to satisfy the condition for regarding hate crimes as a distinct class of crimes, hate crimes arguably send out a terroristic message to members of the victim's group in the immediate neighborhood and beyond. The damage inflicted therefore goes above and beyond the damage to the individual victim. In the words of one commentator, "violence constitutes a threat of more violence to minority group members" (Weinstein, 1992, p. 8). Again, though, to justify the greater punishment of hate crimes as a separate class of crimes, it needs to be demonstrated that the terroristic impact of a hate crime usually goes above and beyond the perceived threat behind the underlying crime without the bias motivation. Although this is strongly believed to be the case, there has been very little empirical investigation to determine whether this is actually so. One respondent indicated how the particular terroristic impact of hate crimes might work:

If you know of a really horrendous crime that takes place, a beating or a rape, or something ... you listen to the news and you say to yourself ... part of what your mind is saying, "Could this happen to me?" And if you hear that a beating was over a drug deal, you say, "Nah, that wouldn't happen to me because a drug deal-I don't do that stuff." ... But these random ones, you can't find a way to make yourself less vulnerable. It exists, and you say, "Yeh, how can I protect myself?" So one is the random danger. Second, is the group danger. A group of offenders on a single victim is much more scary than a single one to one. So more of these hate crimes are done by groups. And the fact that they're not for money, they're not to gain possessions.... So if you do the traditional things like not carrying hard cash and all 
that it doesn't make you less vulnerable to them. So that a lot of the characteristics of hate crimes that we know are characteristics of crimes that are more scary to a community. . . . Serial killings are the same way. Serial rapes are the same way. They have a differential impact because they seem to have a shared set of characteristics that makes crimes more scary to us as people than do others. (R14)

There is an emerging consensus in the literature that little is known about the effects of hate crimes beyond the impact on the initial victims. Even the effects on the initial victims are underresearched. The question is, To what extent are hate crimes more harmful than the same underlying offense without the bias motivation? This is an empirical question, and it is a question that has barely been answered beyond assertion. The omission is significant because the alleged greater harm inflicted by hate crimes provides a key justification for greater punishment. It is also significant because understanding the harm involved will arguably inform effective intervention with victims.

\section{NOTES}

1. The spring element provided the main body of the pilot project. It was made possible by a grant from the British Academy. The aim of the pilot was to test out the feasibility of an investigation of the perceived value of hate crime legislation among communities with a stake in the debate about legislation. Potential respondents were identified on the basis of their involvement in policy debate and policy activity on hate crimes. Academic literature, newspaper reports, and word-of-mouth recommendation provided the purposive sample of potential respondents. None of the potential respondents approached refused to be interviewed. Fourteen respondents were interviewed using a topic guide. Interviews were tape-recorded and a transcription subsequently prepared for analysis. The analytic strategy drew from a grounded theory approach to data analysis. Open coding was applied to the early interviews followed by axial coding around the category of justification for hate crime laws, which inductively emerged as being significant in the early interviews. This category provided a focus for the later interviews, but the initial topic guide was additionally used. Consequently, the data used for the article constitute only one element of the body of data collected in total. The winter element of the project was undertaken to focus specifically on the issue of harm inflicted by hate crimes. It was made possible by a grant from the Nuffield Foundation. The goal was to clarify some dimensions of the emergent ideas around harm from the first element. Four new respondents were purposively selected for their particular expertise in relation to the issue. Two respondents from the first element were interviewed again. The data from these six interviews were incorporated into the analytic process.

2. Respondent numbers are provided after each verbatim quote in the article to give the reader a sense of the range of respondents from whom the data are drawn.

3. Respondents agreed to be named as participants in the pilot project without statements in the research reports attributed to them by name. They are named below to thank them for participating in the research and to give the reader an indication of the coverage of the sample. Thanks are due to: Leonard Alkins, president, National Association for the Advancement of Colored People, Boston; Daniel Bibel, Crime Reporting Unit, Massachusetts State Police; Christina Bouras, executive director, Governor's Task Force on Hate Crimes, the Commonwealth of Massachusetts; Andrea Cabral, chief, District Courts, Suffolk County District Attorney's Office; Richard Cole, chief of the Civil Rights Division, Office of the Attorney General, Massachusetts; Carmen Curry, Community Disorders Unit, Boston Police; Brian Flynn, Boston Police; Steven Freeman, legal director, Anti- 
Defamation League, New York; Don Gorton, cochair, Governor's Task Force on Hate Crimes; Scott Harshbarger, former attorney general, Massachusetts, professor of criminal justice and law, Northeastern University; Jeff Jacoby, staff reporter, Boston Globe; Fred Lawrence, professor of law, Boston University School of Law; Jack Levin, director of the Brudnick Center on Violence and Conflict, Northeastern University; Lauren Levin, Eastern States Civil Rights counsel, Anti-Defamation League, Boston; Jack McDevitt, codirector, Center for Criminal Policy Research, College of Criminal Justice, Northeastern University; David Shannon, Victim Recovery Program, Fenway Health Center; Harvey Silverglate, civil rights lawyer; and Ernesto Whittington, Community Disorders Unit, Boston Police.

4. The U.S. Department of Justice, Bureau of Justice Assistance (1997), has forcefully made this point in its monograph, A Policymaker's Guide to Hate Crimes, in which it argues,

The simple truth about hate crimes is that each offense victimizes not one victim but many. A hate crime victimizes not only the immediate target but every member of the group that the immediate target represents. A bias-motivated offense can cause a broad ripple of discomfiture among members of a targeted group, and a violent hate crime can act like a virus, quickly spreading feelings of terror and loathing across an entire community. Apart from their psychological impacts, violent hate crimes can create tides of retaliation and counterretaliation. Therefore, criminal acts motivated by bias may carry far more weight than other types of criminal acts. (p. x)

5. According to Rehnquist,

The Wisconsin statute singles out for enhancement bias-inspired conduct because this conduct is thought to inflict greater individual and societal harm. For example, according to the State and its amici, bias motivated crimes are more likely to provoke retaliatory crimes, inflict distinct emotional harms on their victims, and incite community unrest. The State's desire to redress these perceived harms provides an adequate explanation for its penalty-enhancement provisions over and above mere disagreement with offenders' beliefs and biases. (Wisconsin v. Mitchell, 1993b)

6. See Note 4.

\section{REFERENCES}

Adelman, L., \& Moorshead, P. (1995). Bad laws make hard cases: Hate crime laws and the Supreme Court's opinion in Wisconsin v. Mitchell. Gonzaga Law Review, 30(1), 1-27.

Anti-Defamation League. (1998). 1999 hate crimes laws. New York: Author.

Barnes, A., \& Ephross, P. H. (1994). The impact of hate violence on victims-Emotional and behavioural responses to attacks. Social Work, 39(3), 247-251.

Craig, K. M. (1999). Retaliation, fear, or rage. An investigation of African American and White reactions to racist hate crimes. Journal of Interpersonal Violence, 14(2), 138-151.

Garnets, L., Herek, G. M., \& Levy, B. (1992). Violence and victimization of lesbians and gay men: Mental health consequences. In G. M. Herek \& K. T. Berrill (Eds.), Hate crimes. Confronting violence against lesbians and gay men. Newbury Park, CA: Sage.

Gey, S. G. (1997). What if Wisconsin v Mitchell had involved Martin Luther King, Jr.? The constitutional flaws of hate crime enhancement statutes. George Washington Law Review, 65, 1014-1070.

Gross, K. A., \& Kinder, D. R. (1998). A collision of principles? Free expression, racial equality and the prohibition of racist speech. British Journal of Political Science, 28, 445-471. 
Herek, G. M., Gillis, J. R., Cogan, J. C., \& Glunt, E. K. (1997). Hate crime victimization among lesbian, gay, and bisexual adults. Journal of Interpersonal Violence, 12(2), 195-215.

Jacobs, J. B., \& Potter, K. A. (1997). Hate crimes: A critical perspective. Crime and Justice, 22(1), $1-50$.

Jacobs, J. B., \& Potter, K. A. (1998). Hate crimes. Criminal law \& identity politics. New York: Oxford University Press.

Jacoby, J. (1998a, July 20). Kennedy's destructive hate crimes bill. Boston Globe.

Jacoby, J. (1998b, October 15). The lessons of Laramie. Boston Globe.

Lawrence, F. M. (1999). Punishing hate. Cambridge, MA: Harvard University Press.

Levin, B. (1998). Motive matters. Klanwatch Intelligence Report [Online]. Available: http:// www.splcenter.org/klanwatch/kw-4g6.html

Levin, B. (1999). Hate crimes. Worse by definition. Journal of Contemporary Criminal Justice, 15(1), 6-21.

Levin, J., \& McDevitt, J. (1993). Hate crimes: The rising tide of bigotry and bloodshed. New York: Plenum.

Marshall, C., \& Rossman, G. B. (1999). Designing qualitative research (3rd ed.). Thousand Oaks, CA: Sage.

U.S. Department of Justice, Bureau of Justice Assistance. (1997). A policymaker's guide to hate crimes. Washington, DC: Author.

Virdee, V. (1997). Racial harassment. In T. Modood, R. Berthoud, J. Lakey, J. Nazroo, P. Smith, S. Virdee, \& S. Beishon (Eds.), Ethnic minorities in Britain. Diversity and disadvantage (pp. 259289). London: Policy Studies Institute.

Weinstein, J. (1992). First Amendment challenges to hate crime legislation: Where's the speech? Criminal Justice Ethics, 11(2), 6-20.

Wisconsin v. Mitchell, 508 U.S. 476 (1993a).

Wisconsin v. Mitchell, 113 S. Ct. at 2201 (1993b). 


\title{
Ethno-National Conflict and Hate Crime
}

\author{
ROGER MAC GINTY \\ University of York, United Kingdom
}

\begin{abstract}
This article will examine the role of hate crime in situations of ethno-national conflict. It will examine the nature of violence used in ethno-national conflict before going on to examine some of the factors that may limit the incidence or visibility of hate crime in cases of ethnic conflict. These factors include the dynamic of the conflict, ethnic segregation, and paramilitary monopolization of violence. The article will also examine the impact of peace processes, or attempts to reach political settlements in ethno-national conflicts, on hate crime. It will conclude by highlighting some of the contextual differences between the United States and other deeply divided societies in relation to hate crime.
\end{abstract}

What is the difference between a prejudice-motivated assault in a city in the United States and a similar incident in a deeply divided society such as Northern Ireland or South Africa? At a micro and human level, there will be little difference for the victim. But, the context between the cases is significant and has an impact on the debate on hate crime.

Northern Ireland, Israel/Palestine, and South Africa have all had crises of political legitimacy and have hosted sustained, violent conflicts driven by identity issues. All three contain diverse populations living in close proximity to each other. Each area also provides names synonymous with violent acts or massacres such as Omagh, Hebron, or Soweto. In short, all three conflict areas provide an environment conducive to hate crime. The United States, on the other hand, is rarely regarded as a "deeply divided society" in the sense that it is host to a violent and explicit ethnic conflict. ${ }^{1}$ Yet, death rates from violence in many major U.S. cities regularly outstrip those in Belfast, Jerusalem, and Johannesburg, even if measured in per capita terms. Furthermore, the United States is host to significant levels of hate crime. Even if the precise levels of hate crime are contested, there is little doubt that the United States has produced particularly high-profile hate crime incidents such as the cases of James Byrd in Jasper, Texas, and Matthew Shepard in Wyoming (Clinton Urges Crackdown, 1998; "Klan: The Next Generation," 1998). ${ }^{2}$

The major difference between the United States and the other conflict areas is that the former is host to what may be described as an undeclared war, or an identity-driven conflict that does not possess a cloak of political legitimacy. The other conflict areas are host to more formal and politicized conflicts. This

AMERICAN BEHAVIORAL SCIENTIST, Vol. 45 No. 4, December 2001 639-653

(C) 2001 Sage Publications 
distinction has important implications for the conceptualization of hate crime in situations of ethno-national conflict. An added complication stems from the fact that the term hate crime tends to be most closely associated with the United States. ${ }^{3}$ It is not, though, solely a U.S.-based phenomenon. The term hate crime is not current in either Northern Ireland or South Africa, where the approximations are sectarian and racial. Whereas the term hate crime suggests a personalization of violence, the existence of wider conflicts in situations of ethno-national conflict tends to steer interpretations toward more general and societal views of violence.

This article will examine the role of hate crime in situations of ethno-national conflict. It will examine the nature of violence used in ethno-national conflict before going on to examine some of the factors that may limit the incidence or visibility of hate crime in cases of ethno-national conflict. It will also examine the impact of peace processes on hate crime. It will conclude by highlighting some of the contextual differences between the United States and other deeply divided societies in relation to hate crime.

\section{VIOLENCE IN ETHNO-NATIONAL CONFLICT}

Terms such as ethnic or ethno-national conflicts conjure images of war-torn societies beset by humanitarian catastrophe and large-scale population movements through ethnic cleansing. Given the experience of the 1990s, such conceptualizations are understandable. Much ethno-national conflict is low profile, however. Many ethnically contested societies manage to contain conflicts for extended periods. A closer examination of the nature of violence in ethno-national conflict situations may be worthwhile, particularly in attempting to assess the role of hate crime in such situations. A key point is that violence is not somehow ethnic. Brubaker and Laitin (1998) noted that "the 'ethnic' quality of ethnic violence is not intrinsic to the act itself" (p. 444). Instead, the term ethnic relates to the interpretation of the violence. Often the interpretations of violence are contested. A violent act may have multiple motivations and interpretations; the perpetrator and victim may variously interpret an action as criminal, political, or random or as motivated by religion, ethnicity, race, or identity. The key point is that violence in ethno-national conflict is a complex phenomenon. It may vary in scale, complexity, intensity, longevity, number of actors, degree of external involvement, and military sophistication of the combatants. As a result, seemingly simplistic terms such as hate crime must be approached with caution.

Much of the violence in ethno-national conflicts is of a low level, taking the form of intermittent street assaults, rioting, vandalism, and assassinations rather than all-out war between fully mobilized states or highly organized groups. In other words, it is similar in form to much of the hate crime in the United States or other largely stable and plural societies. Often, ethnic violence will not seriously threaten the integrity of the state in which it occurs - this is particularly the case 
if the violence is geographically limited to certain regions of the state. Furthermore, much ethnic violence takes place in concentrated bursts, with long periods of tension leading to relatively short outbreaks of violence. Violence in an ethno-national conflict may also be of a structural nature. It may take the form of a partisan and discriminatory judicial and security sector or of laws deliberately designed to exclude certain sections of society. As a result, hate crime may not necessarily relate to a specific violent incident but instead to more environmental conditions that contribute toward violence. This violence may have such an everyday nature that it risks a certain degree of "acceptance" (Collins, 1998, pp. 917-938). The key point is that ethnic tension or friction is often a more common pattern than full-scale violence in an ethnically divided society. ${ }^{4}$

The centrality of identity in ethno-national conflicts often results in a strong attachment to symbols as a focus for group identification. This may mean the deliberate choice of symbolic targets in hate crime incidents in an attempt to maximize offense and visibility. The importance of symbols may be inflated in ethnically divided societies, with symbols acquiring a real political value. In many stable polities, symbolic issues are often regarded as just that: symbolic, peripheral to the political core, and capable of offering a metaphor for wider political or social developments. In a deeply divided society, heightened sensitivity to cultural and identity issues may mean that symbols are drawn into the political core and become credited with an absolute worth (Firth, 1973, p. 427; see also Harrison, 1995). The very fact that certain groups may hold certain types of art or imagery, certain days or certain locations in high esteem, may in turn make these symbolic targets for opposing groups or individuals. The choice of such targets can have an impact far beyond those immediately affected, for example, having a resonance with a Diaspora community.

Another feature of the violence associated with ethno-national conflicts relates to the prominent role played by civilians. Ethno-national conflicts are usually distinguished by the fact that they are fought in the territory in which the combatants live. The result may be twofold: the blurring of the demarcation between civilians and combatants that may be found in interstate wars and high civilian casualties. Because the focus of an ethno-national conflict is often a people, culture, and identity, rather than an army, state, or ideology, civilians assume a prominent role as actors rather than bystanders in the conflict. This is reinforced by the part-time, organic, and ad hoc nature of many of the armed groups involved in ethno-national conflicts. This was vividly illustrated in Kosovo in 1999 where Serb militias were said to be little more than local Serb farmers with a police escort. Similarly, the distinction between members of the Kosovo Liberation Army and the local Kosovar Albanian population was often unclear (see, for example, "Ten Years Old," 1999). A further complication stems from the tendency to interpret hate crime as an individualized or personalized form of violence. In many ethnic conflicts, the individual may hold a quasi-civilian and quasi-military position. Combatants or semicombatants operating in largely civilian rather than military environments may find it easier to 
conceptualize violence against them as personal rather than impersonal. So, although part of a wider conflict, a victim may see significant elements of hate crime in a particular violent incident.

A final point worth making on the nature of violence in ethno-national conflicts is that it is often subject to certain regulations or norms of conduct (Glenny, 1996, p. 186). These differ from conflict to conflict and are informed by a wide range of factors including the type of combatants (state or armed group), the level of reciprocity in the conflict, and the degree to which the combatants are influenced by international opinion, international law, and the work of advocacy groups. In some ethno-national conflicts, violence may be restricted to members of armed groups, with the combatants making a conscious effort to avoid civilian casualties, perhaps because they are sensitive to international media and nongovernmental organization scrutiny. In other conflicts, however, the targeting of civilians lies at the core of a military and political strategy, as is the case with ethnic cleansing. These "rules" of ethnic war are rarely written and are subject to change, but it is worth bearing this implicit regulation in mind when thinking of hate crime in ethno-national conflict.

Many of the aspects of the violence found in ethno-national conflict situations are also present in more stable societies such as the United States. For example, in the United States, much of the hate crime is low level and persistent. It is often highly symbolic and follows certain norms or patterns such as the repeat targeting of certain individuals or sites, or even the avoidance of certain targets. The key difference seems to lie in the political aspects of the violence. In the context of a deeply divided society with an ongoing ethno-national conflict, violence can assume a mantle of political legitimacy through connections with organized groups or causes articulated in a sophisticated manner. Such options are rarely available in less volatile societies. As a result, incidents of hate crime are often interpreted at the individual and personal, rather than political, level.

\section{STRUCTURAL CONTROLS ON HATE CRIME}

Hate crime is not endemic in ethno-national conflict situations. Instead, structural factors help regulate its level and visibility. Three structural controlling factors are particularly prominent: the dynamic of the conflict, high levels of ethnic segregation, and paramilitary monopolization.

\section{THE DYNAMIC OF THE CONFLICT}

Conflicts are rarely static. They tend to move along a cycle according to the intensity of violence, the type of violence involved, and the level of political activity. Certain stages of the conflict cycle provide more opportunities for hate crime than others. A range of factors determines the stage that the conflict occupies in the conflict cycle. These include the type and intensity of the violence, 
the violent capacity of the protagonists, state responses to the violence, and the course of political initiatives designed to manage the conflict or secure advantage for one protagonist or another. External interventions, seasonal factors, and the development or acquisition of new weaponry may all affect the type or intensity of the conflict.

An examination of the modern phase of the Northern Ireland conflict, from 1969 onwards, may help illustrate the point that different phases of a conflict offer different opportunities for hate crime. Mass civil rights demonstrations and protests in the late 1960 s, mainly by the Catholic nationalist community, led to street conflict with the police force. A reactionary populist response by Protestant unionists led to direct Catholic-Protestant confrontation and violence. Large-scale rioting, particularly in Belfast, resulted in loss of life and significant movements of population as Protestant and Catholic minorities were intimidated from their homes. Between 1969 and 1973, 60,000 people left their homes in Belfast (Murtagh, 1995, p. 220). Within a relatively short space of time, however, the three main protagonists in the conflict (the British state and the Catholic and Protestant communities) rationalized their involvement in violence. The British state introduced its army to take over from a stretched and partisan local police force. In the medium term, this contributed to a sharp increase in death rates. These fell over the longer term as more sophisticated security measures were introduced. The sheer presence of the British Army, interposed between the Catholic and Protestant communities, significantly reduced the opportunity for direct Catholic-Protestant violence (Darby, 1991, pp. 3-4).

Apart from the British state, the two other main protagonists were the Catholic nationalist and Protestant unionist communities. The majority in both communities eschewed violence, or at least direct involvement in it. Substantial minorities, however, were supportive of violence, either explicitly or implicitly. Militant organizations developed within both communities. They organized and orchestrated riots. They assumed responsibility for the defense of their own areas and enclaves. They also armed themselves and soon adopted offensive rather than defensive postures. Stones and bottles gave way to guns and explosives. Direct confrontations between Catholic and Protestant mobs gave way to more dedicated and lethal forms of violence such as assassinations or bombings. Quite simply, it became too dangerous for large crowds of rioters to stay on the streets. ${ }^{5}$

Through the 1970s and 1980s, a direct war developed between the principal nationalist militant group, the Irish Republican Army (IRA), and the British Army and its proxies. Targeting became increasingly specific (see White, 1997). The IRA concentrated on trying to kill British soldiers and members of the local police force and militia. British counterinsurgency measures grew increasingly sophisticated. Blunt instruments such as intensive patrolling and internment without trial were, with time, complemented with the assassination of nationalist militants and electronic surveillance. 
Protestant unionist militant groups were less discriminate in their targeting, often targeting Catholic victims at random. ${ }^{6}$ Given that the rationale for many loyalist killings was that "any Catholic will do," it is tempting to categorize much loyalist violence as "hate crime" (Cadwallader \& Wilson, 1991). But a deeper, more political, motivation lay behind the loyalist campaign. The targeting of Catholics was an attempt, albeit bluntly, to discourage Catholic support for the IRA. It also sent out a message reaffirming perceived roles of dominance and subordination in society.

The chief point is that much violence became regularized and more professional. What had begun as mainly horizontal violence between communities became vertical violence involving the state and proxies acting on behalf of communities. Horizontal conflict, such as rioting, can reach unsustainable levels. In the 1987 to 1993 period, more than 1,500 Palestinians were killed and 12,000 were imprisoned for Intifada-related offenses (King, 1994, pp. 185186). It is worth asking if the Intifada could have been sustained in the absence of significant political change. Situations of vertical violence are more easily sustained. A division of labor spreads the burden of the conflict among the community. Importantly, vertical violence also reduces the opportunities for hate crime.

A key difference between a violent ethno-national conflict situation and a relatively stable society subject to hate crime is the range of movement along the conflict cycle. In the former case, there can be sudden movement from a politically tense stage to more intensive violence. The opportunities for hate crime can change as the nature and intensity of the conflict change, but it is by no means automatic that more intense conflict results in more hate crime. Instead, the various controls on more organized conflict may actually limit or mask hate crime. More stable societies, although prone to hate crime, are unlikely to witness sudden movement along the conflict cycle. As a result, persistent hate crime risks becoming part of the fabric of society and accepted as such.

\section{ETHNIC SEGREGATION}

A primary reason for the control of hate crime in deeply divided societies is the high degree of ethnic segregation. This is often most visible in terms of residential segregation with sharply delineated areas for different communities. Demographic engineering, such as the creation of townships, pass laws, and Group Area Acts in apartheid South Africa, meant the movement of almost 4 million people. ${ }^{7}$ The very word apartheid means separateness. The issue of land and territory is central to the Israeli-Palestinian conflict, with the city of Jerusalem providing a classic example of almost total residential segregation (Bollens, 1998, p. 7). In Northern Ireland, residential segregation has increased enormously in the past 30 years, to the extent that $50 \%$ of people live in an area that is inhabited by $90 \%$ or more of their coreligionists (McKittrick, 1993). High levels of residential segregation point to pogroms; deliberate mass clearances, often 
using violence; and restrictive legislation governing land ownership and tenancy rights. It also points to the centrality of territory in many ethno-national conflicts.

A crucial, and often overlooked, point is that residential segregation holds certain advantages. To a certain degree, it is even "popular." In a deeply divided society, it is often much easier to live within a majority than a minority community. More pertinently, it is often a good deal safer. Life in a single-community setting is less challenging. ${ }^{8}$ With residential segregation comes segregation in schooling, shopping, and leisure activities. ${ }^{9}$ Although much segregation may initially develop because of the need for physical security, it can lead to a self-perpetuating ghettoization. In many cases, ghettos become institutionalized and even encouraged by the state (Bollens, 1998, pp. 7-9). If the ghetto becomes large and secure enough, it can offer a high degree of insulation from the conflict. Because opportunities for direct intergroup conflict are diminished, hate crime may be minimized. Interface areas on the boundaries of the enclave, shared arterial routes, and town centers become possible areas for conflict and hate crime, leaving the bulk of the enclave area relatively stable. ${ }^{10}$

Belfast, the capital city of Northern Ireland, provides a good example of segregation along sectarian lines. ${ }^{11}$ The east of the city is almost exclusively Protestant, whereas the west is almost exclusively Catholic. The north contains an uneasy mix of Protestant and Catholic enclaves. Territory is not shared. The two communities live beside one another but not with one another. When the current violent phase of the conflict began in the late 1960s, there were significant population shifts of minorities either out of the city altogether or into enclaves where they composed the majority. As a result, the vast majority of the city's population live in areas in which their group is the majority. ${ }^{12}$ Shops, schools, and leisure facilities that solely serve their enclave mean that it is possible to minimize contact with the other group. Violence, usually in the form of rioting, at the interface of Catholic and Protestant areas led to the erection of high fences between neighborhoods. These so-called peace lines physically divide the city and its people. They are popular among residents who often call for them to be increased in height and made more secure ("Protestants Call for 'Peace Line,'" 1998). The reality of residential segregation is recognized and even institutionalized by the city planners. For example, "neutral space" such as freeways and industrial parks has been deliberately sited between communities to prevent direct Catholic-Protestant interaction. Given sensitivities over territory, the public housing authority is careful not to allocate vacant housing in Protestant areas to Catholic tenants, despite a growing Catholic population (Murtagh, 1995).

Such residential segregation is hardly unique to deeply divided societies with ongoing conflict. Many societies contain gated communities (segregation by economics) or areas traditionally favored by particular immigrant groups. In respect of residential segregation, stable societies with hate crime have similarities with deeply divided societies. Yet, the boundaries between areas in the latter 
are often more rigidly maintained, and often with a greater degree of intimidation and violence.

\section{PARAMILITARY MONOPOLIZATION}

Another control on hate crime in deeply divided societies is the regulation of intergroup hostility by nonstate militant organizations or paramilitaries. ${ }^{13}$ They tend to monopolize a community's violent response and are often ruthless toward competitor organizations from within their own community. In a similar way, they frown on lone operators - often a source of hate crime. So-called loose cannons could jeopardize the dominant paramilitary group's operations and incur disproportionate security responses from state forces. In Northern Ireland at least, revenge attacks by victims' families, without the help of paramilitary groups, are virtually unheard of. This is despite the fact that the names of suspected perpetrators are often well known.

Whereas much paramilitary violence may be viewed as deliberately sectarian and verging on hate crime, paramilitary organizations are careful to present their violence as politically motivated. For example, in Northern Ireland, IRA attacks on the local police force and economic targets often killed Protestants and damaged Protestant-owned businesses. For Northern Ireland's Protestant population, these attacks were motivated by sectarian hatred. ${ }^{14}$ For the IRA, however, these attacks were politically motivated. In the words of one strategist, they were designed to "break the political will of the British government, and the British people, to remain here" (Morrison, 1985, p. 7). Regardless of actual motivation-and it is difficult to know the precise motivations of a secretive, organic organization-paramilitary groups worked hard to present a political motivation for their activities. They adopted militaristic language. The IRA, according to itself, was engaged in a "war." ${ }^{15}$ Loyalist (pro-British) and republican paramilitary organizations boasted conventional military structures such as brigades and battalions. Paramilitary groups accompanied their attacks with demonizations of their victims. Politically uninvolved victims were accused of being members of rival paramilitary organizations or the state forces.

The key to a sustained campaign by a paramilitary organization is continued legitimacy. The sources of legitimacy could be local, earned through the defense of the community, or international, via a diaspora community. Seemingly sectarian attacks or blatant hate crimes risk damaging this legitimacy. In short, hate crime makes for bad politics. Furthermore, outright military victory is an unrealistic goal for many paramilitary organizations. They lack the capacity to defeat conventional, standing armies. Thus, the rationale behind paramilitary campaigns is often "armed propaganda" (O'Doherty, 1997, p. 109). The real aim is to keep a situation in the headlines in the hope of an international initiative or raise the costs of occupation to unsustainable levels. Again, the key point is that hate crime was not always the most efficient way for paramilitary organizations to secure their goals. It could even be counterproductive. 


\section{HATE CRIME IN PEACE PROCESSES}

The term peace process is often used to describe sustained efforts to reach a political accommodation in a protracted, low-intensity ethno-national conflict. A peacemaking process involves the chief protagonists in the conflict and addresses the key conflict issue(s) in a serious manner. For example, an attempt by a government to reach a deal with a minor insurgency group on cultural inclusion issues while ignoring larger groups and major constitutional issues at the heart of a conflict cannot be properly considered a peace process. Peace processes are often sustained, as the term process suggests, and are able to withstand occasional outbreaks of violence. Also crucial to a peace process is a significant voluntary aspect; the protagonists have a real investment in the process. The nature of peace processes has changed over the past decade, with a marked decline in UN involvement and an increase in indigenous initiatives and the efforts of regional organizations. Another trend has been the tendency for peace processes to assume competency over a broader range of issues. Although still concentrating on political and constitutional issues, many modern peace processes have addressed issues of social, economic, and cultural inclusion as well as economic regeneration and truth recovery (for further coverage of this issue, see Darby \& Mac Ginty, 2000). Cease-fires often play a key role in peace processes; they create a space in which political negotiations can take place. Yet, cease-fires rarely guarantee an end to violence that may persist from a number of sources and for a variety of reasons. The nature of violence, including hate crime, is subject to change during a peace process.

There is strong evidence to suggest that hate crime increases during peace processes. Certainly, in Northern Ireland there has been a noticeable increase in arson and vandalism attacks on identifiably Catholic or Protestant property since the peace process has begun. Schools, homes, businesses, churches, church halls, Orange Order halls, and sports halls have all been targeted (see, for example, "Arsonists Hit Churches," 1995; "Church, Orange Hall Damaged," 1995; and "Concern at Number of Arson Attacks," 1995). There has been an increase in direct Catholic-Protestant street confrontations and other protests, such as economic boycotts, articulated in a primarily sectarian format (see, for example, "Protestant Businesses Boycotted," 1996, and "Drumcree Reaction Leads to Boycott," 1996). Much of this hate crime-type violence has been related to the parades dispute. This violence marked a distinct change from the pre-peace process phase of the conflict in which sectarian motivations were often masked. In other words, the Northern Ireland peace process has been marked by a decline in violence in which the political motivations of violence were emphasized and an increase in overtly sectarian violence. The transition to majority rule in South Africa was marked by enormous violence, with more than 16,000 people losing their lives in the 1990 to 1994 transition period. ${ }^{16}$ Most of this violence was Black on Black, between supporters of the African National Congress and the Inkatha Freedom Party, and did not directly involve one of the 
key participants in the peace process, the government. The Oslo process in Israel/Palestine has also heralded renewed upsurges in violence in that area, much of it specifically related to wider political developments and much of it with the characteristics of hate crime.

But why would hate crime, or other types of violence, increase during a peace process, a process specifically designed to bring about a political settlement and involving the main protagonists in the conflict? A primary motivation for ethnic violence is fear. Groups or individuals may feel that their relatively privileged economic or political position in society is under threat and take steps to secure it. Alternatively, they make take action as the result of the words or actions of another group. Crucially, a peace process is an extraordinary period of political activity in an ethnic conflict. It may promise and deliver landmark agreements, far-reaching reforms, and symbolic meetings between (former) enemies. It is not surprising, then, that fear of political change, common in many ethnically contested societies, becomes intensified during a peace process. There is a strong tendency, on all sides, to perceive the situation in zero-sum terms. Each side perceives its own concessions as yet another erosion of an already embattled political position that is not sufficiently appreciated or reciprocated by the other side. Political change is often viewed as exclusively negative. Given that many peace processes are elongated, it can seem as though the entire peace process is geared toward the diminution of one's position. In such an environment, hate crime may be encouraged.

A key point about hate crime during peace processes is that it is often carried out by individuals, or groups of individuals, rather than by paramilitary organizations. Given that paramilitary organizations will often be party to the peace process, it is in their interest to show a high degree of discipline. The continued involvement of their political representatives in negotiations often requires a strictly observed cease-fire. There was significant evidence of the main republican and loyalist paramilitaries "policing" other paramilitary groups within their communities in Northern Ireland during the peace process (see, for example, "Attack on Bar May Signal Beginning of Loyalist Feud," 1997, and "UVF Will 'Wipe Out' Rival Loyalists," 1997). Paramilitary groups also controlled community protests lest they become violent and jeopardize wider political goals ("Street Patrols Planned," 1999). Violence, particularly in a gratuitous form such as hate crime, would be regarded as a gross violation of the cease-fire. Where paramilitary groups do engage in violence during peace processes, it tends to become more firmly linked with the political process. It is often timed and modulated in intensity according to political factors.

Whereas paramilitary groups privy to political negotiations (often secret talks) may be disciplined during a cease-fire, individuals and groups of individuals who are not privy to this information may become unnerved by political uncertainty. Mainstream paramilitary control of communities may relax during cease-fire periods, allowing individuals and groups of individuals the opportunity to engage in hate crime. ${ }^{17}$ The peace processes in Northern Ireland, Israel/ 
Palestine, and South Africa were all accompanied by a greater "informalization" of violence. Attacks were carried out by previously (and subsequently) unheard of paramilitary groups, suggesting that they lacked political legitimacy and military infrastructure. The choice of target often fitted the hate crime model, eschewing pretensions of a military or political motivation for highly symbolic targets.

Crucial to the informalization of violence during peace processes is the development of breakaway or splinter groups from the larger paramilitary organizations. Peace processes place paramilitary organizations under enormous strain. Often, the pressures to call and maintain cease-fires, to negotiate, and to compromise prove too much for some hard-line elements within a paramilitary organization. A split may result. These splinter organizations may have looser lines of command and less rigid rules of engagement. Their very raison d'être is to derail the peace process, hence, the sobriquet "spoiler group" (Stedman, 1997). In attempting to shock people, political parties, and governments away from the peace process, blatant hate crime may be employed. A peace process may thus offer individuals and groups of individuals the motivation and opportunity to engage in hate crime. Furthermore, heightened sensitivities because of possible political change, and the absence of mainstream paramilitary activity, award any hate crime greater significance and headlines.

But, peace processes are rarely the scene of unrestrained hate crime, even by spoilers. Again, there are controlling factors. The timing of much hate crime is deliberate, often coinciding with major political developments. The vast majority of serious hate crime, such as intimidation from housing, takes place in a 2 -week period in Northern Ireland's marching season. It is no coincidence that a grenade attack aimed at Israeli civilians in the southern Israeli town of Beersheba took place during a 1998 Israeli-Palestinian summit in the United States ("Israel Focuses on Security Issues," 1998). Nor was it coincidental that Palestinian extremists bombed Jerusalem's main fruit and vegetable market in November 1998 at the precise moment when the Israeli cabinet was meeting to discuss and ratify the Wye Accords ("Wye Debate Suspended," 1998). The seeming political sophistication of these attacks raises questions about precise motivation. Such deliberately timed attacks are not carried out for the sake of hate. They are political acts, aimed at influencing wider political developments.

A "successful" peace process by no means guarantees an end to hate crime. Xenophobia is widespread in postapartheid South Africa, with immigrants and asylum seekers being particular targets for attack (Morris, 1998). Despite the new political dispensation, old targets retain their salience. Statistically, one member of the White farming community is killed every 3 days (Laurence, 1998). The attacks also raise questions of motivation (Meares, 1998). Are they motivated by hate or robbery or both? Questions of motivation are central to any discussion of the role of hate crime in a deeply divided society. A close examination of many violent acts in deeply divided societies reveals that they are not motivated by simple hate. This is not to deny underlying motivations of 
prejudice. It is, instead, to highlight a more complex motivational environment. Prejudice may well form the basis for many violent actions in a deeply divided society, but hate crime is often an inefficient form of violence. For this reason, political and tactical considerations may come into play. Furthermore, a series of structural factors - the dynamic of the conflict, ethnic segregation, and paramilitary monopolization — controls levels of hate crime.

\section{CONCLUSION}

The question posed in the introductory sentence is still outstanding: What is the difference between a prejudice-motivated assault in a city in the United States and a similar incident in a deeply divided society such as Northern Ireland, Israel/Palestine, or South Africa? A key difference is the politicization and scale of conflict in deeply divided societies that host ethno-national conflict, as opposed to the United States. This is not to deny the existence of violent divisions in U.S. society. Instead, it is to highlight that the undeclared nature of the conflict in the United States means that interpretations of violence in that case are often seen through the lens of the individual and emotion. As a result, prejudice-motivated attacks in the United States may be labeled as hate crime, whereas they may be more easily regarded as a more general social and political phenomenon in deeply divided societies. This distinction may be a little artificial, however. An argument can be made that all hate crime is political and that the key difference lies in the context in which the violence takes place and the manner in which the motivation for the violence is articulated. ${ }^{18}$

All hate crime is political in the sense that it involves a statement that goes far beyond a particular act of violence or intimidation. It involves the identification of a target, the objectification of the targeted individual(s), and the depersonalization of the victim. Often, hate crimes have a deliberately public aspect that is meant to convey a warning to a wider community. This is evidenced through the daubing of synagogues with offensive graffiti or the decision to tie Matthew Shepard to a fence post as a deliberate act of humiliation. Again, the humiliation is deliberate and is designed to send out a message of dominance and subordination. Buford O'Neal Furrow, who admitted shooting five people at a Jewish community center in Los Angeles in August 1999, told FBI agents that he wanted to "send a message [italics added] to America by killing Jews" ("US Nazis Find Their Latest Hero," 1999). In the context of a declared war, such incidents move away from simple hate or personalized incidents and are subsumed in a wider conflict. They become institutionalized into military and paramilitary activity and can attain a veneer of political legitimacy. In the United States, where much ethnic violence takes the form of an undeclared war, this option is not open. As a result, there is a tendency to interpret violence in emotional and personal terms: hate. Many of those perpetrating the violence, however, are anxious to acquire a political and military legitimacy for their actions. Hence, they 
consciously ape military uniforms, language, and structures. Those bodies with the task of combating hate crime have a delicate task; clearly, they must take the threat seriously. Yet, inflated governmental approaches to isolated incidents may give those individuals and groups engaged in hate crime the legitimacy they crave.

\section{NOTES}

1. This is not to say that the United States is a society without divisions.

2. Jacobs and Henry (1996) challenged the notion of a hate crime epidemic in "The Social Construction of a Hate Crime Epidemic."

3. Contemporary U.S.-based literature on the issue includes Czajkoski (1996); Collins (1998); and Green, Glaser, and Rich (1998).

4. Schmid and Jongman (1997) referred to the "political tension situation" in their conflict escalation model.

5. This pattern of the increased use of firearms was replicated in the Palestinian Intifada. Bar-On (1996) noted that "despite the explicit prohibition by the Intifada leadership of the use of firearms, guns were now used with greater frequency" (p. 258). King (1994) noted that the use of guns was "turning the intifada into something more like a conventional uprising" (pp. 186-187).

6. According to Bruce (1992), "republican paramilitaries form only a very small proportion of the victims of loyalist violence. 71.8 per cent were 'civilian Catholics"” (p. 5).

7. The figure comes from Ginwala (1985, p. 12). A comprehensive account of segregation is provided by Davenport (1991, pp. 518-533). Robinson (1996) is also instructive, particularly in relation to specific areas; see, for example, the section on the clearing of Korsten in the mid-1950s (pp. 159-168).

8. Donnan and McFarlane (1983) explored the motivations for segregation in Northern Ireland-from kinship to intimidation.

9. An excellent account of a single-religion education can be found in Boggs (1985). Boggs noted that he was only taught "Protestant" or British history: "I left school without knowing that there had been a famine in Ireland" (p. 18).

10. According to Bollens (1998), "Jewish casualties were higher in the city of Jerusalem than elsewhere, with many political murders occurring along the old boundary 'seam" (p. 4).

11. A history of segregation in Belfast can be found in Hepburn (1994).

12. Of Belfast's 51 electoral wards, 35 are at least $90 \%$ one religion or the other (McKittrick, 1993).

13. The term paramilitary is used in Northern Ireland to denote nonstate, guerilla, or insurgency groups. In other contexts, paramilitary refers to groups with links to the state.

14. According to John Dunlop (1995), a former moderator of the Presbyterian church in Ireland, "while republicans have said that their armed struggle is against the British, they have mostly killed their Protestant neighbours, destroyed their businesses and bombed their towns" (p. 124).

15. Hence the War News section in the Sinn Féin newspaper An Phoblacht/Republican News, which listed Irish Republican Army activities.

16. For accounts of violence during the South African transition to majority rule, see Catholic Institute for International Relations (1996, pp. 22-31) and Wilson (1997, pp. 19-23). Hamber (1998) outlined the various types of violence employed and the various motivations in Who Pays for Peace? Implications of the Negotiated Settlement for Reconciliation, Transformation and Violence in a Post-Apartheid South Africa.

17. Cusack (1998) noted that an increase in violence and anti-Catholic intimidation in one housing estate in Northern Ireland is largely due to a fragmentation of command structures in the dominant paramilitary group, the Ulster Defence Association. As a result, local commanders acted 
autonomously without reference to the more politically aware leadership. It is important not to regard paramilitary organizations as monolithic. Members may have joined for different reasons, some with ideological principles, others with an interest in racketeering, and others still who are motivated by hate or revenge.

18. Much of this discussion stems from comments from Marie Smyth of the Cost of the Troubles Study, Belfast.

\section{REFERENCES}

Arsonists hit churches, halls and cars in north. (1995, August 22). The Irish Times.

Attack on bar may signal beginning of loyalist feud. (1997, August 22). The Irish Times.

Bar-On, M. (1996). In pursuit of peace: A history of the Israeli peace movement. Washington, DC: United States Institute of Peace Press.

Boggs, R. (1985, December 2-15). A Protestant education in Londonderry. Fortnight: An Independent Review for Northern Ireland, 230, 17-19.

Bollens, S. A. (1998, Spring). Uncovering the urban dimension in nationalist conflict: Jerusalem and Belfast compared. Terrorism and Political Violence, 10(1), 1-38.

Brubaker, R., \& Laitin, D. (1998). Ethnic and nationalist violence. Annual Review of Sociology, 24, 423-452.

Bruce, S. (1992). Northern Ireland: Reappraising loyalist violence [Research Institute for the Study of Conflict and Terrorism paper]. Conflict Studies, 249, 5.

Cadwallader, A., \& Wilson, R. (1991, May). A case of any Catholic will do. Fortnight: An Independent Review for Northern Ireland, 295, 6.

Catholic Institute for International Relations. (1996). South Africa: Breaking new ground. London: Author.

Church, Orange hall damaged in arson attacks. (1995, August 25). The Irish Times.

Clinton urges crackdown on hate crimes [Online]. (1998, October 12). Available: http:// news.bbc.co.uk/hi/english/world/americas/newsid\%5F190000/190861.stm (British Broadcasting Corporation Web site)

Collins, P. H. (1998, September). The tie that binds: Race, gender and US violence. Ethnic and Racial Studies, 21(5), 917-938.

Concern at number of arson attacks in north. (1995, August 23). The Irish Times.

Cusack, J. (1998, July 22). Police seal off streets in search of estate hit by “orchestrated attacks.” The Irish Times.

Czajkoski, E. H. (1996). Criminalizing hate: An empirical assessment. Federal Probation, 56(3), 36-40.

Darby, J. (1991). What's wrong with conflict? (Occasional paper). Coleraine, Ireland: Centre for the Study of Conflict.

Darby, J., \& Mac Ginty, R. (Eds.). (2000). The management of peace processes. London: Macmillan.

Davenport, T.R.H. (1991). South Africa: A modern history (4th ed.). London: Macmillan.

Donnan, H., \& McFarlane, G. (1983). Informal social organisation. In J. Darby (Ed.), Northern Ireland: The background to the conflict (pp. 110-135). Belfast, Ireland: Appletree Press.

Drumcree reaction leads to boycott of Protestant firms. (1996, August 24). The Irish Times.

Dunlop, J. (1995). A precarious belonging: Presbyterians and the conflict in Ireland. Belfast, Ireland: Blackstaff Press.

Firth, R. (1973). Symbols public and private. London: Allen \& Unwin.

Ginwala, F. (1985). Indian South Africans (Minority Rights Group Report 34). London: Minority Rights Group.

Glenny, M. (1996). The fall of Yugoslavia (3rd ed.). London: Penguin. 
Green, D. P., Glaser, J., \& Rich, A. (1998). From lynching to gay bashing: The elusive connection between economic conditions and hate crime. Journal of Personality and Social Psychology, $75(1), 82-92$.

Hamber, B. (1998, October 30). Who pays for peace? Implications of the negotiated settlement for reconciliation, transformation and violence in a post-apartheid South Africa. Paper presented at AGM of Catholic Institute for International Relations, London.

Harrison, S. (1995). Four types of symbolic conflict. Journal of the Royal Anthropological Institution, 1(2), 255-272.

Hepburn, A.C.H. (1994). Long division and ethnic conflict: The experience of Belfast. In S. Dunn (Ed.), Managing divided cities (pp. 88-104). Keele, UK: Keele University Press.

Israel focuses on security issues following attack. (1998, October 20). The Irish Times.

Jacobs, J. B., \& Henry, J. S. (1996). The social construction of a hate crime epidemic. Journal of Criminal Law and Criminology, 86(2), 366-391.

King, J. (1994). Handshake in Washington: The beginning of Middle East peace? Reading, UK: Ithaca Press.

Klan: The next generation. (1998, June 12). Independent (London).

Laurence, P. (1998, August 15). Murders of Whites fuel fears of anarchy. The Irish Times.

McKittrick, D. (1993, March 21). Apartheid deepens in Ulster. Independent (London).

Meares, R. (1998, July 3). Alleged armed robbers shot dead in manhunt. The Irish Times.

Morris, A. (1998, November). "Our fellow Africans make our lives hell": The lives of Congolese and Nigerians living in Johannesburg. Ethnic and Racial Studies, 21(6), 1116-1136.

Morrison, D. (1985, September 23-October 6). Confusing and unhappy for loyalists. Fortnight: An Independent Review for Northern Ireland, 225, 7-8.

Murtagh, B. (1995). Image making versus reality: Ethnic division and the planning challenge of Belfast's peace lines. In W.J.V. Neill, D. S. Fitzsimons, \& B. Murtagh (Eds.), Reimaging the pariah city: Urban development in Belfast and Detroit (pp. 209-230). Aldershot, UK: Avebury.

O'Doherty, M. (1997). The trouble with guns: Republican strategy and the provisional IRA. Belfast, Ireland: Blackstaff Press.

Protestant businesses boycotted for Drumcree. (1996, August 5). The Irish Times.

Protestants call for "peace line." (1998, August 5). The Irish Times.

Robinson, J. (1996). The power of apartheid: State, power and space in South African cities. Oxford, UK: Butterworth-Heinemann.

Schmid, A. P., \& Jongman, A. J. (1997, Winter). Violent conflicts and human rights violations in the mid-1990s. Terrorism and Political Violence, 9(4), 166-192.

Stedman, S. J. (1997, Fall). Spoiler problems in peace processes. International Security, 22(2), 5-53.

Street patrols planned. (1999, July 1). [Belfast] Community Telegraph.

Ten years old, with a bullet in his arm, he saw 19 of his family killed. (1999, April 6). Guardian.

US Nazis find their latest hero. (1999, August 15). Observer.

UVF will "wipe out” rival loyalists. (1997, August 25). Irish News.

White, R. W. (1997, Summer). The Irish Republican Army and sectarianism: Moving beyond the anecdote. Terrorism and Political Violence, 9(2), 120-131.

Wilson, R. A. (1997). The people's conscience? Civil groups, peace and justice in the South African and Guatemalan transitions. London: Catholic Institute for International Relations.

Wye debate suspended after Hamas bombing. (1998, November 7). The Irish Times. 


\title{
Renaming Violence
}

\author{
DEBRA RENEE KAUFMAN
}

Northeastern University

\begin{abstract}
A gender analysis forces us to measure and define our sociological inquiries in ways that broaden categories of human experiences. In so doing, we are often forced to rename those experiences. In this analysis of violence, gender, and the Holocaust, we will look to the extra burden, in addition to race, that gender forced on women: rape, abortion, sexual victimization, pregnancy, childbirth, the killing of newborns, and decisions about separation from children. In this analysis, we will look to the ways in which gender forces us to revisit the meaning of violence through the sins of omission as well as commission, through a deepening of the understanding of public and private spheres of life, and to expand what we mean by victims, survivors, and resisters.
\end{abstract}

A recent tribute, of which I was a part, given at the 1999 American Sociological Association (ASA) meetings to Mirra Komarovsky, ${ }^{1}$ who had died earlier in the year, took the form of an intellectual foray into the field of gender role studies. From her earliest piece written in 1946, and then onward, Komarovsky gave us the intellectual tools from which the relationships between practice and theory, behavior and principle, the individual and the role were to emerge. Prescient is the word many would use of her remarkable insights into role analysis and the consequences these insights were to have for our understanding of the relationship between behavior and role - the consequences of gender, class, ethnicity, and context in our understanding of human behavior. In this article, role theory, particularly gender role theory, provides the theoretical analysis of gender and the Holocaust.

Several issues raised by Komarovsky about gender role research apply to the analysis of one of the most extreme forms of violence-war. Role analysis forces us to look at the sociocultural and structural level to explain violent behavior rather than prematurely ending, as Komarovsky might put it, with psychological explanations. Gender role theory, in particular, helps us to empirically locate many of the issues heretofore neglected or simply unobserved in the study of war. For instance, by focusing not just on the formal roles played by those involved in perpetuating the Holocaust during World War II, but on the informal ones as well, we expand our understanding of the term perpetrators. Unlike role theory, which is often characterized as focusing exclusively on

AMERICAN BEHAVIORAL SCIENTIST, Vol. 45 No. 4, December 2001 654-667

(C) 2001 Sage Publications 
explanations for conformity through internalization of norms or as too focused on consensus, gender role theory, as Komarovsky so early noted, allows us to directly address issues of ambivalence, conflict, deviation, and malintegration. The following discussion of gender issues and the Holocaust will address some of the persistent problems in role analysis, for instance, the disjunction between professed values and actual behavior. By looking at the ways in which public and private were redefined by the SS to reinforce the need for the violence and horror perpetrated, we see how internalization of norms is simply too weak an explanation for the existence of conformity by either perpetrators or victims. Moreover, an analysis of gender role issues shows how violations of gender role stereotypes, as well as gender role conformity, were integral to the persistence and use of violence. A gender role analysis allows us to perceive the ways in which violations of our gender role stereotypes take place through the human capacity to redefine situations and maintain fictions. From Nazi wives and mothers who deliberately ignored or remained ignorant of the violence around them, to the women who were forced to kill their own babies or perform abortions on others to save lives, it is clear that theoretical formulations must stay in touch with the "lived experiences" of the role performers in order for us to understand practice.

Before we can sociologically understand violent behavior, we must learn how to name it in all of its dimensions-when it begins, when it ends, where the geographic and time boundaries are, who are the perpetrators, and who are the victims. War affects men and women differently. As the introduction to The Women and War Reader (Lorentzen \& Turpin, 1998) suggests, women play many more roles during wartime than men. In addition, women are more likely to be killed in war and to become war refugees than men. It is important to note, however, that the profound differences in experience are not to be understood in simplistic gender/sexual dichotomies. Gender, like class, race, ethnicity, and religion, conditions and intersects with our many roles and statuses in complex and multidimensional ways. Therefore, if we use male victims, survivors, and perpetrators as our only normative model, we have an incomplete understanding, not only of those roles, but of the experiences that separated women from men. A gender analysis forces us to measure and define our sociological inquiries in ways that broaden categories of human experiences. In so doing, we are often forced to rename those experiences. In this analysis of violence, we will look to the extra burden, in addition to race, that gender forced on women: rape, abortion, sexual victimization, pregnancy, childbirth, the killing of newborns, and decisions about separation from children. In this analysis, we will look to the ways in which gender forces us to revisit the meaning of violence through the sins of omission as well as commission, through a deepening of the understanding of public and private spheres of life, and to expand what we mean by victims, survivors, and resisters. 


\section{THE MYTH OF GENDER NEUTRALITY AND OTHER MISNOMERS}

In her provocative article "Troubling Categories I Can't Think Without: Reflections on Women in the Holocaust," Ruth Linden (1996) made clear that "victims and survivors of the final solution have, for decades, generally been represented by an ideal-type figure who appears to be genderless, yet, in fact, is "biologically and culturally male/masculine"" (p. 19). Linden "troubles" her categories of analysis by asking herself, and all authors writing about the Holocaust, to begin by signaling their intellectual and political commitments to such categories as "women," "gender," "Holocaust," "Jews," "power," "agency," "victims," "survivors," and "memories" (p. 18). Should, for instance, we take for granted that we know when the Holocaust began and when it ended? What constitutes Holocaust research? What geographic and time spans are we speaking of when we speak of the Holocaust? Should we, asked Linden, limit our research to women in the ghettos and camps where the focus of traditional Holocaust research has been and thereby maintain a focus on the epicenters of power and destruction? What then do we know about women who lived on the margins of the occupation, those who hid in the countryside and in the cities, those who "passed" on the Aryan side with falsified papers, and those who worked with the resistance? $?^{2}$ Are second and third generations of survivor families considered part of "Holocaust" research?

Perhaps an even more elusive question arises when we look at the gendered ways in which we come to understand the terms survivors and victims. In her discussion of the works of Anne Frank and Eli Wiesel, Mary Lagerwey (1996) insisted that whereas both The Diary of Anne Frank and Night are canonical metanarratives about the Holocaust, the gendered nature of each constitutes the ways in which contemporary audiences have popularized and received this pair of stories. She wrote,

The initial representative life of an Auschwitz survivor has been male, (i.e., Elie Wiesel). His voice, the voice of a singular man-has become the voice of the Holocaust survivor. In contrast, as a girl frozen in death at the age of fifteen, Frank speaks for the dead, for children, and thus is not so much an exemplary life, but a sympathetic victim. Frank-only a year younger than Wiesel-has come to represent adolescent female victims rather than all Holocaust victims. ... Elie Wiesel's story has become the story of Auschwitz survivors, if not the story of Holocaust survivors. (Lagerwey, 1994, pp. 6-7)

Lagerwey's concerns are not about the legitimacy of Frank's and Wiesel's voices but about the ways in which gender inferences may take place. Her point is that there are two kinds of voices from the Holocaust: one male voice representing the experiences of survivors, those who were successful and the authors of their own stories, and only one female voice, those who were powerless, representing the experiences of the many dead victims. The experience of violence 
is retold in very gendered ways. Frank's story, insisted Lagerwey, comes to us as a woman's narrative (a diary) and is less authoritative. On the other hand, the Auschwitz survivor becomes not only Wiesel, but the "archetypical male," who is in authority and control of the way his life's story is told. Frank is outside the realm of adult issues of power and control (Lagerwey, 1996).

In his perceptive article on violence against women, Michael Smith (1994) suggested something similar in the ways in which women and men are described in the abuse literature. Smith warned that we must be aware of the experiences of violence from the perspectives of women, not just from the perspectives of the researchers who are in authority over their subjects and the ways in which violence is studied. He, like Lagerwey, pushed us to break from master narratives often based on masculine experiences and assumptions, to look to the experiences of the women themselves. He, too, suggested we move to the margins of experience to understand its full enormity. For instance, Smith pushed us to the margins of our topic when he identified women who have witnessed abuse against other women as part of our understanding of violence against women. By staying in touch with the experiences of those both in the center and on the margins, we attempt to maintain a continuity between theory and experience (in the everyday lives of both men and women) and to stay in touch with those experiences in the rendering of our analyses.

Whereas the issues of racism and the Holocaust have been raised by writers, sexism and the Holocaust have been less discussed. Objections to the introduction of sexism into Holocaust research often represent political fears that a focus on sexism might have the unintended effect of reducing the Holocaust to "just" an example of sexism or may detract from the "real" issue of anti-Semitism. The editors of Different Voices offered the following counter to these fears:

Precisely because the Nazis targeted Jews and others in racial terms, they had to see those victims in their male and female particularity. Far from reducing the Shoah to an example of sexism, emphasis on what happened to women reveals what otherwise would remain hidden: a fuller picture of the unprecedented and unrelenting killing that the "Final Solution's" antisemitism and racism entailed. (Rittner \& Roth, 1993, p. 4)

\section{GENDER AND THE USES OF VIOLENCE}

Sybil Milton (1993) noted that violence against female political opponents began immediately after Hitler took power. The first targets were socialist, communist, and moderate liberal parliamentary deputies on the national, state, and municipal levels. However, not only were women held hostage for their own acts but for "politically active male relatives in flight or in hiding" (p. 215). This "politics of reprisal," wrote Milton, "led to the arrest of wives, sisters and daughters for the political activities of their absentee male relatives" (p. 215). Interestingly, Milton suggested that prior to 1938, Jewish women were more vulnerable 
to verbal assaults than to physical violence in early encounters with Nazi vigilantes. Moreover, Jewish women were arrested in those early years, not as Jews, but as members of these socially despised categories. Normative social inhibitions based on cultural understandings of gender still prevented "street violence against even Jewish women, despite their position as social pariahs" (p. 217). Her main point is that prior to 1939 , "ideological hostility was not immediately transformed into physical violence," and despite their despised category, neither "racist propaganda nor government pressure could modify traditional behavior patterns toward 'weaker' members of society" (p. 217). It has been hypothesized that one of the reasons for the higher rates of international emigration by Jewish young and middle-aged single men than by women, after 1933, had to do with the mistaken thought that the Nazis would not treat Jewish women, children, and the elderly as harshly as they did the men. In those early years, it was hard to dismiss notions of traditional gender role behaviors and expectations.

Prior to 1939, there is some slight support for this understanding. The inspector of the concentration camps, SS Captain Max Koegel, requested the construction of 30 to 40 detention cells at the new Ravensbruck facility. He wrote,

It is impossible to maintain order if the defiance and stubbornness of these hysterical females cannot be broken by strict confinement, since no more severe punishment can be used in a women's camp. Denial of food does not suffice for discipline and order in a women's camp. (cited in Milton, 1993, p. 222)

After an inspection by Himmler, corporal punishment for women inmates was introduced, although, as Milton contended, it had existed in the men's concentration camps almost from the first (p. 223).

\section{GENDER: EXPANDING OUR NOTIONS OF RESISTANCE AND SURVIVAL}

Survival patterns inside the camps after 1939 show that women had "significantly different survival skills and techniques than did men" (Milton, 1993, p. 227). Milton (1993) wrote that German Jewish women and women of other nationalities used similar strategies for coping with this "unprecedented horror" (p. 227). "Women's specific forms of survival," she wrote, "included doing housework as a kind of practical therapy and of gaining control over one's space, bonding and networks, religious or political convictions" (p. 227). Cleaning, for instance, not only served as therapy but aided in helping to prevent the spread of disease. Often responsible in the past for feeding and caring for their families, women shared recipes, sewing skills (stitching pockets underneath their skirts to carry concealed food back to the camps), and tricks for expanding the meager resources available. Indeed, the clinical research by physicians in the Warsaw Ghetto, suggested Milton, confirms impressionistic data that women were less 
vulnerable to the effects of short-term starvation and famine than men. Vignettes and diaries by women interned in the camps reveal that women's traditional domestic roles as wives, daughters, and mothers aided in reducing the spread of disease and consequently decreased mortality in the women's barracks. ${ }^{3}$ Because most women had been primarily responsible for the feeding and caring of their families, there was some direct correlation between their own survival and these gendered skills (p. 227). Whereas bonding because of religious or political convictions may not have been specific to women, Milton wrote that the "degree of group cohesion and noncompetitive support available to women seems markedly greater than among men" (p. 230). Again, these observations seem consistent with traditional gender role stereotypes of middle-class women and men of that period of time. The argument rests on the assumptions that gender roles, more than instinctual or even psychological and temperamental differences, were at play in accounting for different patterns of survival and resistance.

Whether this group cohesion might account for the resourcefulness and skillfulness women exhibited in passing messages between jail cells and barracks, on work details, and during roll calls is not known, but it appears that women were better at these forms of resistance than men (Milton, 1993, p. 231). Milton (1993) noted that women were "more skilled at trading cigarettes and food to obtain essentials for their friends and prison families" (p. 231).

In her paper titled Survival, Resistance and Disguise: Passing for Gentile, Lenore Weitzman (1995) addressed some of the gendered issues around Jewish resistance during the Holocaust. She argued that a "masculine" view is dominant in our understanding of resistance. By assuming that the only-or the most important - forms of resistance taken by Jews were those that used guns and weapons excludes and ignores vital roles played by women such as rescuing and saving others as couriers for the underground. Her research explores the resistance activities of women who lived outside of the ghettos on the "Aryan side": women, whom Linden (1996) might describe as portrayed on the margins. Weitzman described women's activities, such as carrying vital information, smuggling food, and transporting individuals to safe places, as critical forms of resistance.

Grounding her analyses in the experiences of women and staying in touch with those experiences in drawing her conclusions about both men and women, Weitzman (1995) asked why such women are not defined as resistance fighters. She wondered why we save that term only for those who aggressively attacked and killed Germans. Why is killing a German more an act of resistance than saving a Jew? Similarly, Nechama Tec (1996), when writing of the experiences of men and women in the forests, concluded that acts of defiance consisted more of acts of survival than outright resistance. That is, even if they wished to engage in armed struggle, women who fled to the forests, in general, were not allowed to carry guns. Similarly, male partisans, who were allowed to carry guns, used their 
weapons more in the act of scavenging for food and in frightening farmers than in armed struggle with their enemies.

In her recounting of the Budy Incident at Auschwitz, Deborah Dwork (1995) asked why this incident was never characterized as a revolt or as an act of rebellion. Dwork suggested that because we reconstruct history to reflect our specific disciplinary assumptions and prejudices, especially about gender, we find that no one believed that educated Jewish women would have considered, or were even capable of, such a masculine and aggressive act as a full-fledged revolt. Sorbonne students and artists do not "go down to the level" of vulgar prostitutes, stated one SS lieutenant arrested immediately after the war by the British when he gave his captors a detailed account of the incident. Dwork questioned our reliance on this SS lieutenant's account (p. 17). In a one-line private diary entry, in fact the only contemporary account that we have of the incident, Johanna Kremer, one of the prisoners, names the experience a "mutiny" (p. 21). Dwork wondered,

Was it not in the German's best interest to suppress the very idea of an attempted revolt, and to quell the notion that Jewish intellectual women are capable of violence or concerted action, thus rendering the Jewish women even more powerless? (p. 21)

Feminist contributions to the study of the Holocaust, suggested Dwork, locate our inquiries just at the beginning of our understanding of the social history of Europeans-Jewish and gentile_-during the Shoah. She claimed we are rewriting history by asking questions related to gender. Once again, we see how the structural conditions might better explain the apparent role reversal of these women, rather than deeply internalized and irreversible gender role norms.

\section{GENDER, CLASS, AND RACE: RECOGNIZING THE SINS OF OMISSION AND COMMISSION}

Playing on the special spheres of influence and holding their expected places in Nazi society, German women sustained the Reich's racism and genocide, including the ways in which those policies targeted women in particular (Koonz, 1993, p. 287). Koonz (1993) argued that even if the Nazi state gave women little direct political power, women did have their spheres of influence. And although relatively few German women directly participated in the "final solution," Koonz reasoned that by creating home environments that kept the private, feminine world of the family separate and isolated from the masculine sphere of political duty, the elite Nazi wives sustained the Third Reich's racism and genocide. Nazi wives "gave the individual men who confronted daily murder a safe place where they could be respected for who they were, not what they did" (p. 288). Koonz argued that "far from wanting to know the details of their men's 
public lives," these women cultivated instead their own ignorance of public life and thereby further helped their men avoid facing responsibility for participation in the Holocaust (p. 288).

The reworking of traditional gender stereotypes around the public and private split is one of the more interesting examples of the ways in which conformity to roles is contextually structured rather than a by-product of early internalization of norms alone. For instance, the ideal of womanhood and traditional notions of the privacy of the family were reworked by the Nazi state depending on whether it was the elite cadre of Nazi leaders or the general population. Koonz (1993) wrote,

Paradoxically, the Nazi state, which sedulously undercut all forms of privacy and attempted to destroy parental influence over children, actually encouraged traditional notions of the family when selecting SS commanders who would oversee genocide. For all the emphasis on breeding programs and unwed motherhood, the Nazi leaders and SS chiefs remained as petty bourgeois as they accused their enemies of being. They relied on the sheltering family (or on its myth) to keep alive an ersatz sense of decency in the men who would work most closely with mass murder. (p. 299)

Whereas we might easily dismiss the men who issued and carried out genocidal orders as pathological murderers, Koonz (1993) formulated a more devastating and even more disturbing picture of the practice of such evil. The Nazis knew that the impact of such brutality on the men would have to be addressed. How could the SS and Nazi leaders manage to remain sane while committing subhuman jobs? We see the interplay between gender and nationalism when Koonz wrote,

In the name of obedience to a higher law, officers were admonished to abolish from their hearts "feminine" traits such as sentimentality or squeamishness. They were to think of the long-term gain for all "Aryans," which vindicated the evil they wrought in the short term. ... Equally important, leaders encouraged their men to feel proud of their brotherhood - a tough, elite force. To perform well in a concentration camp ... meant to be a "real man," to be ruthless, obedient, loyal without moral scruples toward subhumans, and scrupulously honorable to equals. (p. 295)

Koonz's analysis allows us to see that overidentification with one's role is too simple an analysis of the ability to commit genocide. Nazi leaders, contended Koonz (1993), wanted "dedicated, cold administrators of death, not killers among their elite. Nor did they want madmen" (p. 296). By emphasizing the split between their public and private selves, these elite killers were allowed to distance themselves from their actions (role distance) while simultaneously maintaining the image of dedicated professionals, husbands, and fathers.

Unlike Koonz, Gisela Bock (1998) placed greater emphasis on the similarities than on the differences between the German men and women who carried out their genocidal and brutal jobs. She looked to the ordinary (non-Jewish) 
German women, not the elite cadre of SS wives and family, who were mobilized to implement Nazi policies. These women, contended Bock, were mobilized on the basis of their worker, not female, status. She posed the undermining of gender role stereotypes and the accentuation of nationalist identities as she described some of the women who took part in the antinatalist goals of National Socialism. Prior to 1939 , sterilization was the method of elimination of those considered "inferior" for ethnic or eugenic reasons. However, from 1939 on, race hygiene included the killing of inmates of psychiatric asylums. Women were among the perpetrators, as well as the victims, of these crimes (p. 87). Bock wrote,

Nurses in the six killing centers assisted the "professional killers" and sometimes killed on their own. They were not forced to perform this task and were not punished if they rejected it, as is evident from many cases when nurses resisted and sometimes were able to help their patients. All Jewish inmates of such asylums were killed. This was the first instance of a systematic massacre of German Jewish women and men. (p. 87)

Later, she pointed out that women who actively participated in both eugenic and ethnic racism were often leaders of the Nazi women's elite groups and authors of the women's press. They urged women to accept the sterilization policy, identify possible candidates for sterilization, and reject marriage with Jews, Gypsies, and other "racially inferior" persons (p. 87). Once again, we see the reworking and sometimes reversal of role stereotypes to encourage such actions. Wrote Bock,

Female "materialism" ... became the object of racist polemic and was condemned as "sentimental humanitarianism," as were Christian charity and Marxism. "Women's materialism" and "the female instinct to care for all those in need of help" were "acts against the race." Of "women's particular inclination toward all living beings," it was said that there was "scarcely any worse sin against nature." (p. 88)

Class clearly played a role in how gender stereotypes would be used (compare Bock's use of stereotypes to Koonz's cultural construction of womanhood for SS wives). Bock (1998) pointed out that in their roles as workers, as typists stenographers, and as telephone operators, women knew and passed on innumerable messages and "orders for the implementation of race policies" (p. 89).

Bock (1998) challenged the assumption that gender was key in understanding how Nazi crimes were perpetrated. Rather, she stressed race. She wrote, "Female perpetrators were perpetrators not so much because they were female but because they believed themselves to be ordinary Germans, like the men" (p. 94). However, Bock was too literal in her understanding of the term gender. It is the uses of gender that were key to Nazi policy, not whether Nazi rule essentially meant a radical cult of motherhood and separation of gender spheres. Looking to 
traditional spheres of influence for men and women to explain how they contributed to Nazi policies of genocide and murder is to miss the more nuanced ways in which class, race, and gender intersect to explain gender role behavior. Indeed, Bock's conclusions suggest that she too understood this important interaction. She asserted, "Not only did racism shape the historical expressions of gender, but gender also shaped the historical expressions of racism" (p. 96).

\section{GENDER, THE HOLOCAUST, AND GEOGRAPHIC AND TIME BOUNDARIES}

The effect of gendered violence against women during the Holocaust knows neither geographic nor time boundaries. The specter of unborn children haunts us as much today as does the number who were killed. Skillfully arguing this point in her analysis of Rebecca Goldstein's Mind-Body Problem, Emily Budick (1996) wrote of this loss and of Renee, the protagonist, this way:

The idea of the unborn children is fraught with implication in relation to post-Holocaust Jewish life. The horror of the brutal, tortuous, extermination of European Jewry contains within it the annihilation as well of the unborn generations, who haunt contemporary Jewish life as powerfully as the ghosts of the six million dead. ... As a contemporary Jewish woman, Renee inherits the loss of the unborn millions, who were never conceived, never came to term. And this torment of the child who is not, as the book renders it, and I think, as it exists in reality as well, has particular implications for women. (p. 71)

Budick (1996) made clear that the overwhelming and sometimes neglected feature of the Holocaust is that the Nazis were willing "to exterminate women and children without differentiation alongside the more traditional male victims of military or political conflict" (p. 67). She wrote,

The Nazis did not intend, as in the conventional homo-social policies of war, merely to wipe out male competitors for power. ... Rather, they sought to annihilate an entire contemporary population and, beyond that, the possibility of any rebirth of the population later on. In this light, Jewish women might well experience themselves the particular victims of Nazism, an experience that might increase their sense of obligation geared toward procreation. (p. 67)

\section{GENDER, SEXUALITY, REPRODUCTION, AND VIOLENCE}

In her essay on women in the forced labor camps in Poland, Felicja Karay (1998) revealed that prisoner testimonies reveal several allusions to sexual harassment by overseers, despite the fact that Germans were prohibited from 
such liaisons. Similarly, sexual liaisons between Poles and Jews were forbidden, yet there is evidence that such did occur. The Werkschutz commander Fritz Bartensclager was known to choose "escort girls" for private entertainment. Karay reported that at a feast in his apartment, these escort girls were ordered to serve the guests in the nude and were "ultimately raped by the revelers" (pp. 290-291). In yet another one of his parties, "three women were brutally raped and then murdered" (p. 291). Although the incidence of rape by the Nazis appears to have been rare, it is clear that rumors of rape were used to terrorize many Jewish women. This fear of sexual assault was also experienced by women in hiding (p. 291).

In an interview with her, one respondent tells Joan Ringelheim (1993) of sexual abuse by a number of gentile men while she was in hiding. She ends her story this way: "It was not important ... except to me" (p. 376). But why should sexual abuse have no place in the story of violence and the Holocaust? Ringelheim wrote,

\begin{abstract}
Almost every woman referred to the humiliating feelings and experiences surrounding her entrance to the camp ... being nude; being shaved all over-for some being shaved in a sexual stance, straddling two stools; being observed by men, both fellow prisoners and SS guards. Their stories demonstrated shared fears about and experiences of sexual vulnerability as women, not only about mortal danger as Jews. (p. 376)
\end{abstract}

The use of narratives such as these points to the need for a fuller and more complete set of experiences before social science theories about the Holocaust construct them. By locating these narratives in time and space and from point of view, we begin, as Linden suggested (1996), to bridge the relationship between storytelling and scholarship.

"No one will ever know what it meant to me to destroy those babies" (Perl, 1993, p. 114). Dr. Gisela Perl was an obstetrician and gynecologist who was selected by Josef Mengele to run a "hospital" ward at Auschwitz-Birkenau. Childbirth in the camps presented a particularly pernicious form of gendered violence against women. Perl (1993) recounted that on arrival in Camp C, pregnant women were encouraged to notify the SS chiefs of their pregnancies under the guise that they would be taken to another camp where living conditions were better. Perl recounted,

Even I was naive enough, at that time to believe the Germans, until one day I happened to have an errand near the crematories and saw with my own eyes what was done to these women... They were surrounded by a group of SS men and women, who amused themselves by giving these helpless creatures a taste of hell, after which death was a welcome friend. They were beaten with clubs and whips, torn by dogs, dragged around by the hair and kicked in the stomach with heavy German boots, then when they collapsed, they were thrown into the crematoryalive. (p. 113) 
With exquisite pain, Perl (1993) wrote of how she was simultaneously a midwife and a murderer:

I loved those newborn babies not as a doctor but as a mother and it was again and again my own child whom I killed to save the life of a woman. Every time when kneeling down in the mud, dirt and human excrement which covered the floor of the barracks to perform a delivery without instruments, without water, without the most elementary requirements of hygiene, I prayed to God to help me save the mother or I would never touch a pregnant woman again. And if I had not done it, both mother and child would have been cruelly murdered. (p. 114)

Often, violence against women deliberately focused on the gendered consequences for them as sexual and maternal beings. The violence to women's bodies came in many forms: the loss of menstruation and eventually, for many, even the loss of breasts. As a 13-year-old, Livia E. Bitton Jackson (1993) described the changes in the bodies of the women around her:

The breasts began to sag at first and then became virtual hanging sacks. Some very fat ladies had the most ridiculously hanging empty sacks, like long, narrow, stretched-out empty balloons weighed down by a single marble in each, reaching almost to the navel. Then the empty sacks became shorter. Eventually the skin, too, was absorbed and the breasts disappeared completely. We were all like men.... In time the bones began to protrude and shrunken skin lay taut on every pointed bulge. (p. 81)

She wrote also of the fear of bromide in the food, which was meant to sterilize women:

Married women kept wondering about the bromide in their food again and again. Will they bear children again? What will their husbands say when they find out? Perhaps less of the food will cause less of a damage. Some try to eat less and the conflict is painful. Rejection of a means of survival for the sake of a dubious gain. (Jackson, 1993, p. 80)

\section{CONCLUSION}

This article has been about renaming the experience we call violence: its dimensions, its beginnings, its endings, and its effects. One of the least explored dimensions of the Holocaust is the assumption that there was nothing gendered about this violent experience. A gender role analysis insists that there was nothing gender neutral about the Holocaust. The following quotation from Joan Ringelheim (1996), one of the earliest scholars to note that the study of women was an important corrective to the study of the Holocaust, serves as a fitting ending to this article. In that the final solution of the Nazis against the Jews was genocide ${ }^{4}$ we have come to believe, as scholars and as lay readers, that the 
Holocaust was gender neutral. In the preface to a special edition of Contemporary Jewry, she challenged that assumption with the following:

A careful study of National Socialism as theory and practice does not reveal any more gender neutrality than racial neutrality. Theories and policies about gender are always embedded within racial theories. The eugenics program of the Nazis had particular views about men and women — men and women among so-called Aryans and among so called non-Aryans. The prominent analysts of the Holocaust may have erased or ignored gender, but the Holocaust did not. (Preface, p.2)

\section{NOTES}

1. See, especially, Kaufman (1999).

2. In this article, I will not address these issues but pose the theoretical questions a gender analysis forces us to recognize when we analyze violence. Most of these issues are identified in my guest edition of Contemporary Jewry (1996). Some of these issues are also addressed in Women in the Holocaust, edited by Dalia Ofer and Lenore Weitzman (1998).

3. This observation should not be confused with overall survival rates of men and women because young healthy women were almost immediately eliminated on arrival at camps if they arrived with young children or if they were pregnant.

4. Although the Holocaust included persecution of others on political grounds and as homosexuals, only Roma and Sinti (Gypsies) were subjected to a genocidal policy that parallels the policies against the Jews.

\section{REFERENCES}

Bock, G. (1998). Ordinary women in Nazi Germany: Perpetrators, victims, follower, and bystanders. In D. Ofer \& L. Weitzman (Eds.), Women in the Holocaust (pp. 85-100). New Haven, CT: Yale University Press.

Budick, E. (1996). Feminism, Jewish history, and the Holocaust in Rebecca Goldstein's Mind-Body Problem. Contemporary Jewry, 17, 66-78.

Dwork, D. (1995, November). Incident at Budy. Paper delivered at the Association for the Social Scientific Study of Religion, St. Louis, MO.

Jackson, L. B. (1993). Coming of age. In C. Rittner \& J. Roth (Eds.), Different voices (pp. 73-83). New York: Paragon House.

Karay, F. (1998). Women in the forced labor camps. In D. Ofer \& L. Weitzman (Eds.), Women in the Holocaust (pp. 285-309). New Haven, CT: Yale University Press.

Kaufman, D. (1996). The Holocaust and sociological inquiry: A feminist analysis. Contemporary Jewry, 17, 6-17.

Kaufman, D. (1999, August). A tribute to Mirra Komarovsky. Paper presented at the ASA meetings, Chicago.

Koonz, C. (1993). Consequences: Women, Nazis and moral choice. In C. Rittner \& J. Roth (Eds.), Different voices (pp. 287-308). New York: Paragon House.

Lagerwey, M. (1994). Gold-encrusted chaos: Memoirs of Auschwitz. Unpublished doctoral dissertation, Department of Sociology, Western Michigan University, Kalamazoo.

Lagerwey, M. (1996). Reading Anne Frank and Elie Wiesel: Voice and gender in stories of the Holocaust. Contemporary Jewry, 17, 48-65. 
Linden, R. (1996). Troubling categories I can't think without: Reflections on women and the Holocaust. Contemporary Jewry, 17, 18-33.

Lorentzen, L., \& Turpin, J. (Eds.). (1998). The women and war reader. New York: New York University Press.

Milton, S. (1993). Women and the Holocaust: The case of German and German-Jewish women. In C. Rittner \& J. Roth (Eds.), Different voices (pp. 213-249). New York: Paragon House.

Ofer, D., \& Weitzman, L. (Eds.). Women in the Holocaust. New Haven, CT: Yale University Press.

Perl, G. (1993). A doctor in Auschwitz. In C. Rittner \& J. Roth (Eds.), Different voices (pp. 106118). New York: Paragon House.

Ringelheim, J. (1993). Women and the Holocaust: A reconsideration of research. In C. Rittner \& J. Roth (Eds.), Different voices (pp. 373-419). New York: Paragon House.

Ringelheim, J. (1996). Preface to the study of women and the Holocaust. Contemporary Jewry, $17,1-2$.

Rittner, C., \& Roth, J. (Eds.). (1993). Different voices. New York: Paragon House.

Smith, M. (1994). Enhancing the quality of survey data on violence against women: A feminist approach. Gender and Society, 8, 109-127.

Tec, N. (1996). Women in the forest. Contemporary Jewry, 17, 34-47.

Weitzman, L. (1995, November). Survival, resistance and disguise: Passing for Gentile. Paper delivered at the Association for the Scientific Study of Religion, St. Louis, MO. 


\title{
The Birth and Maturation of Hate Crime Policy in the United States
}

\author{
RYKEN GRATTET \\ University of California, Davis \\ VALERIE JENNESS \\ University of California, Irvine
}

\begin{abstract}
To comprehend the contemporary significance of hate crime, it is necessary to understand how the concept emerged and gained acceptance, as well as how its meaning has been transformed over time and across the institutional spheres of the American policy-making process-from social movements to legislatures to appellate courts and, finally, to law enforcement. As the concept traversed these spheres, its definition and the scope of its application have been substantially clarified. In the process, each institutional sphere placed new constraints on the concept, which restricted its scope in some ways and expanded it in others. The contemporary understanding of hate crime, legally, politically, and culturally, reflects the cumulative efforts of situated actors within and across these spheres. The authors consider how awareness of these general patterns is helpful for evaluating the recent criticisms of hate crime policies.
\end{abstract}

It is beyond question that the recent eruptions of racist, anti-Semitic, and antigay violence have focused unprecedented attention on the topic of hate crime. Indeed, the media chronicles of hate crimes are given fresh installments at alarmingly regular intervals. It seems we are in the midst of a hate "crime wave" (Fishman, 1978). It is fitting, then, that a national law journal has dubbed the 1990s the "decade of hate—or at least of hate crime" (Rovella, 1994).

Hate-motivated violence, however, is perhaps more accurately characterized as an age-old problem approached with a new sense of urgency. This urgency stems from a social process that was set in motion several decades ago. During the 1980s and 1990s, multiple social movements began to devote considerable material and symbolic resources to the problem. Government agencies analyzed the issue. Legislative campaigns sprang forth from every level of government. New sentencing rules and categories of criminal behavior were established in law. Prosecutors and law enforcement developed training policies and

Authors' Note: An earlier version of portions of this article was presented at the International Conference on Hate Crimes held at the Brudnick Center on Violence and Conflict at Northeastern University, November 6-7, 1998. We thank Jack Levin, Les Moran, Nancy Naples, and Gordana Rabrenovic for their assistance and comments.

AMERICAN BEHAVIORAL SCIENTIST, Vol. 45 No. 4, December 2001 668-696

() 2001 Sage Publications

668 
specialized enforcement units. The U.S. Supreme Court weighed in with its rejection of one statutory formula and its acceptance of another. Scholarly commentary and social science research on the topic, including the work contained in this special issue, have exploded. These extraordinary developments attest to the growing concern with and public visibility of violence motivated by bigotry, hatred, or bias. In the process, criminal conduct that was once undistinguished from ordinary crime has been parsed out, redefined, and condemned more harshly than before (Jenness \& Grattet, 2001), reflecting the increasing acceptance of the idea that criminal conduct is different when it involves an act of discrimination. In short, hate crime has clearly secured a place in the American public sphere.

In this article, we argue that hate crime cannot be understood solely in terms of its behavioral manifestations, its statistical frequency, and/or its causal precursors. Instead, as the developments catalogued above indicate, hate crime involves a significant mobilization of people, bureaucracies, and institutions. What we are witnessing is a common, but undertheorized, phenomena: the birth and structuring of a domain of public policy. Accordingly, the way this policy domain has emerged, its key players, organizational practices, and substantive foci, form the backdrop against which the behavior and consequences of hate crime can best be understood.

\section{CONCEPTUALIZING HATE CRIME AS A POLICY DOMAIN}

Throughout this article, we frequently refer to hate crime as a policy domain. As Burstein (1991) noted in his review of the literature on the formation and evolution of policy domains, "Sociologists interested in politics have increasingly turned in recent years to the study of policy domains" (p. 328). He used the term to denote "components of the political system organized around substantive issues" (p. 327). ${ }^{1}$

Policy domains are fundamentally rooted in definitional and classification schemes that are properly characterized as social constructions. This means that the substantive focus and boundaries of policy domains are not based on inherent qualities of "problems." Instead, the distinctions reflect dominant modes of conceptualizing issues. Such distinctions are routinely revealed as "constructed" by social analysts who point out the social conditions are assigned meanings that define their parameters and content (for a review, see Mauss \& Jenness, 2001). Therefore, how issues are constructed has clear implications for how policy domains are structured and the kinds of policies that are brought to bear on any particular social problem. ${ }^{2}$

Our use of the term policy domain implies that the causes and consequences of a problem cannot be fully comprehended apart from an understanding of the larger processes that identified, defined, and ultimately propelled it. More 
specifically, we use the term policy domain to refer to two things. First, it refers to the range of collective actors-for example, politicians, experts, officials, enforcers, and interest groups-who have gained sufficient legitimacy to speak about or act on a particular issue. Second, it refers to the cultural logics, theories, frameworks, and ideologies those actors bring to bear in constructing the problem and the appropriate policy responses.

These dimensions of a policy domain orient us to several considerations with respect to hate crime. Most generally, they suggest that the organization and culture of the hate crime policy domain have shaped the way the problem of hate crime has been defined and the kinds of policies that have been formulated and adopted. Moreover, focusing on policy domains requires recognizing that "policy change takes place through the conjunction of three streams of activity moving fairly independently: problem recognition and agenda setting; the specification of policy options; and the politics of selecting among proposals and enacting legislation" (Burstein, 1991, p. 346). To these three streams we add one more: Policy change continues throughout the lifecourse of policy as the procedures of application in judicial and law enforcement settings are elaborated and refined (Jenness \& Grattet, 2001). Finally, the above conceptualization of policy domains implies a focus on the relationship between social organization and meanings; therefore, it suggests that the problem of hate crime is likely to be understood differently over time, across space, and between institutional locations within the domain.

Temporal, spatial, and institutional variation in the meaning of hate crime occurs because the formation of a policy domain is rooted in the social processes of innovation, diffusion, and institutionalization. That is, the social construction of hate crime and its official responses diffuse not only across jurisdictional and geographical space, but also across the four streams of policy-making process identified above. This phenomenon is contingent on institutionalization, the process by which the meanings and practices that constitute hate crime stabilize, become cognitively taken for granted by actors, and/or attain a high level of normative consensus (DiMaggio \& Powell, 1983; Meyer \& Rowan, 1977; Powell \& DiMaggio, 1991; R. Scott, 1987; Zucker, 1991).

It seems clear, then, that studying hate crime requires exploring the birth and evolution of a policy domain. Accordingly, the analysis presented below is motivated by a series of questions about how social problems, law, and policy domains come into being, are transformed, and are institutionalized over time. For example, with regard to social problems, why is the concept of hate crime only now being applied to age-old conduct? As for law, how have legal and extralegal subjects and conduct related to hate-motivated crime been constructed by key players, most notably, activists, lawmakers, judges, and law enforcement agents?

To address these and related questions, our approach involves an examination of how the concept of hate crime emerged, how its meaning has been transformed across multiple segments of the policy domain, and how it has become 
institutionalized as a social fact and set of policies. Specifically, we focus on how social movements have constructed the problem of hate-motivated violence, how politicians at both the federal and state level have made legislation that defines the parameters of hate crime, how judges have interpreted those laws, and how law enforcement officials classify and manage that which is defined as criminal by statutes. Summarized in Figure 1, we examine the work of these collective actors to reveal the social processes that have resulted in the production of hate crime and hate crime policy, both inside and outside of the justice system.

\section{THE ROLE OF SOCIAL MOVEMENTS IN THE CONSTRUCTION OF HATE CRIME}

The idea of hate crime emerged through the confluence of several social movement discourses, most notably the Black civil rights movement, the women's movement, the gay and lesbian movement, the disabilities rights movement, and the crime victims' rights movement (Jenness \& Broad, 1997). These movements converged to compose the modern anti-hate crime movement (Jenness, 1999; Jenness \& Grattet, 2001; Maroney, 1998), which in turn proved crucial to the development of hate crime in the United States.

The Black civil rights movement of the 1960s was predominantly concerned with the broad issue of discrimination and was therefore geared largely toward establishing and enhancing opportunities within specific sectors of social life, such as employment, education, voting and governmental practice, and public accommodations. There was an understanding within the movement that discrimination was the overarching problem and intergroup violence could be mitigated, at least in part, by using government policy to increase economic opportunities and guarantee civil rights. In other words, the systems that maintained Black marginality were seen as the cause, and occasional episodes of violent repression were a symptom (West, 1993). Thus, efforts to curb the violence were central to the broader goal of inclusion. In addition, the "axes" of discrimination focused on by 1960s civil rights campaigns were restricted to race, religion, national origin, and ancestry (Bensinger, 1992; Morsch, 1991).

The 1970s civil rights movements, specifically the women's movement and the gay and lesbian movement, borrowed heavily from the language and strategies of the earlier movement (Goldberg, 1991; McAdam, 1982; Morris, 1984). They did so to expand the scope of activism in important ways (Jenness, 1995; Jenness \& Broad, 1997; Minkoff, 1995; Vaid, 1995). Most notably, the women's movement and the gay and lesbian movement enlarged the legal conception of what constitutes standard and legitimate subjects of discrimination. Specifically, the axes of discrimination that the law recognized and sought to ameliorate were broadened to include women, as well as gays and lesbians. Although each of these "second wave civil rights movements" (Goldberg, 1991), 


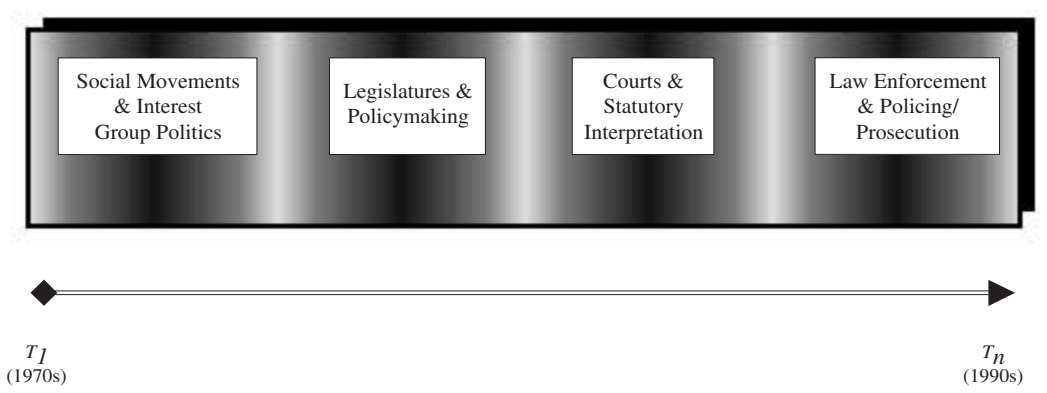

Figure 1: Summary of Select Institutional Spheres Composing the Policy Domain of Hate Crime

like the earlier movement, are strongly geared toward expanding opportunities for its constituencies, each movement also sponsors antiviolence projects to combat discriminatory violence directed at its constituency (Jenness, 1995; Jenness \& Broad, 1997). The emergence and institutionalization of the antiviolence projects reflect a growing understanding that violence is not merely epiphenomenal to the various systems of discrimination; rather, it is central to their maintenance.

The final movement that significantly contributed to the development of the anti-hate crime movement was the crime victims' movement (Maroney, 1998). The crime victims' movement is composed of a fairly diverse range of groups, including some of the groups discussed above. The basic grievance put forth by the crime victim movement is simple: Victims of crime, especially violent crime, not only need but are entitled to special assistance, support, and rights as crime victims. From the point of view of those involved in the crime victim movement, "the criminal justice system was not perceived as providing certainty of justice for the criminal or the victim" (Weed, 1995, p. 21). As a result, advocates for victims' rights argue that legal and extralegal mechanisms are needed to recognize and serve those injured by crime, especially violent crime. Such mechanisms include counseling services and an array of statutes and state constitutional amendments that allow for increased participation of victims in the criminal justice process, protection from retaliation and harassment, and civil actions for compensation (Weed, 1995).

The anti-hate crime movement emerged through a fusion of the strategies and goals of several identifiable precursor movements that laid the foundation for a new movement to question, and make publicly debatable, issues of rights and harm as they relate to a variety of constituencies. One of the major achievements of the anti-hate crime movement is that it unites disparate social movements, what some would refer to as strange bedfellows (Jenness \& Grattet, 2001). As liberal, progressive movements, the civil rights, women's, and gay 
and lesbian movements "called attention to the personal costs of minority groups' political victimization," whereas the more conservative victims' rights movement "called attention to the political context of personal victimization" (Maroney, 1998, p. 579). As portrayed in Figure 2, these liberal and conservative movements combined to instigate public discussions about violence born of bigotry and to demand legal changes, especially in criminal law, to remedy the problem. $^{3}$

The history of the formation of the anti-hate crime movement directly affected the changing character of the hate crime policy domain. Like the broader history of the modern rights movements, participation in the anti-hate crime movement was staggered. Racially and religiously oriented organizations such as the Anti-Defamation League (ADL) and the Southern Poverty Law Center (SPLC) led the way, whereas lesbian and gay and women's groups as well as disability activists joined later. For example, early on, the ADL and the SPLC activity concentrated on compiling statistical reports to establish the empirical credibility of hate crimes directed at the groups they represented, primarily racial, religious, and ethnic minorities. Gender, sexual orientation, and disability were not incorporated into their statistics-gathering efforts and, in the case of the ADL, were not included in the early model hate crime statutes promoted in the early 1980s. Thus, early on the empirical credibility of gender-based and antigay offenses as a type of hate crime was not established by the work of these organizations. ${ }^{4}$ As a result, such acts remained outside the operative construction of hate crime until considerably later in the history of the concept, as we describe below.

\section{SOCIAL MOVEMENT MOBILIZATION TRANSLATED INTO FEDERAL AND STATE LEGISLATION}

Once the anti-hate crime movement was able to bring the issue of discriminatory violence into the public consciousness, the struggle turned to creating some sort of legal and policy response. This activity targeted state and federal legislators to enact statutes embodying social movement goals. In 1981, the ADL created and began to promote a model hate crime law. Five kinds of statutes were included: institutional vandalism (vandalism directed at religious institutions), intimidation (including assault, trespass, vandalism, or harassment), a civil action for both kinds of crime, data collection, and police training law (for a review, see Grattet, Jenness, \& Curry, 1998; Jenness \& Grattet, 1996). These elements continue to form the core policy agenda for the hate crime policy domain.

Proposed early on, however, the ADL model did not initially include sexual orientation, disability, and gender as provisions in hate crime law. Other early advocates, such as the National Institute Against Prejudice and Violence and the Coalition on Hate Crimes ${ }^{5}$ also operated with an emphasis on hate crime as offenses involving violence stemming from racial, religious, and ethnic 


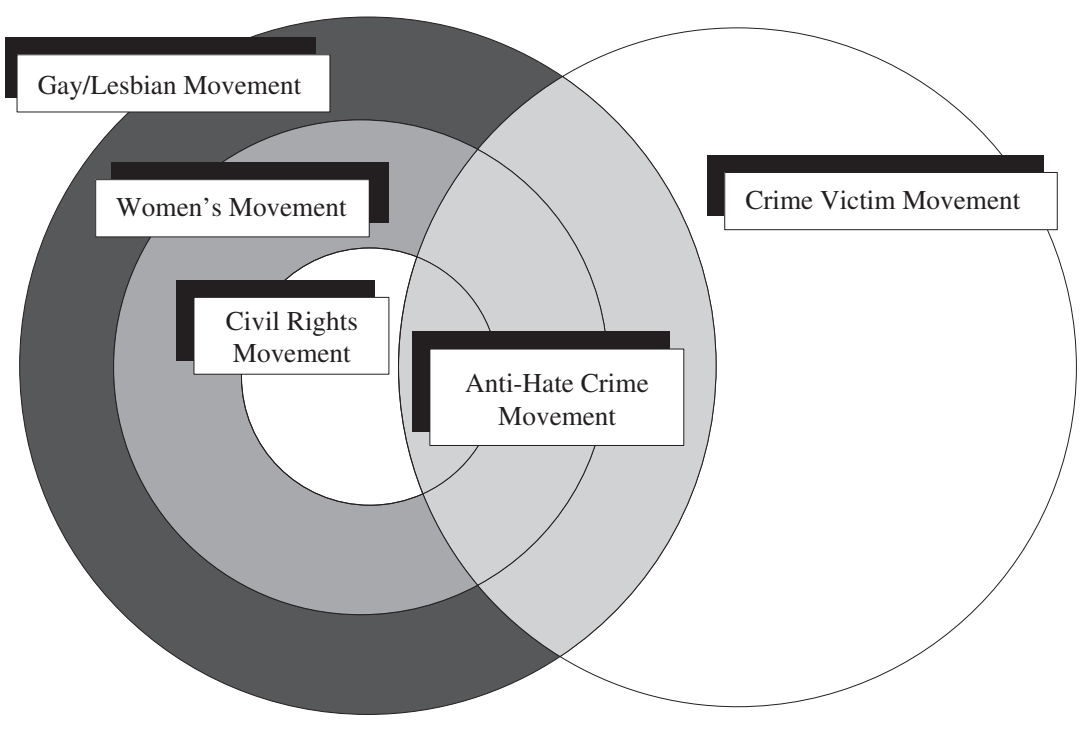

Figure 2: The Convergence of Civil Rights Movements and the Emergence of an Anti-Hate Crime Movement in the Latter Part of the 20th Century

prejudice. Later, as the gay and lesbian and women's activists gained a higher profile on the issue, the ADL modified its model statute to include gender and sexual orientation. This, once again, underscores the staggered way that the different movements and hence different categories or persons were incorporated into the concept of hate crime.

By the mid-1980s, the issue of hate crime reached the U.S. Congress. As of 2000 , nine U.S. Congresses had devoted attention to the task of responding to hate-motivated violence, resulting in hundreds of hours of congressional hearings and debates, as well as three new federal laws: Hate Crimes Statistics Act (HCSA), the Violence Against Women Act, and the Hate Crimes Sentencing Enhancement Act (HCSEA). The legislative histories of these laws reveal how the inclusion of status provisions in hate crime law (i.e., "race, religion, and ethnicity," "sexual orientation," and "gender") ensured that the concept of hate crime expanded to recognize women, gays and lesbians, and people with disabilities as constituencies implicated in the hate crime problem (Jenness, 1999).

Consistent with the recommendation of the Coalition on Hate Crimes, early claims from local-, regional-, and state-level organizations-especially the ADL - focused on the scope and consequences of race-, religion-, and ethnicitybased violence, thus expressing the parameters of the problem in comparatively narrow terms. A growing awareness of this type of violence became grounds for promoting federal hate crime legislation by a limited number of social 
movement organizations and their representatives. This activity cemented a trio of statuses - race, religion, and ethnicity—as the anchoring provisions of all hate crime law. This occurred without controversy over the legitimacy of these status provisions and in light of the fact that race, religion, and ethnicity were already institutionalized as a legitimate subject for federal discrimination law.

Later, the character of hate crime law was reshaped when the domain of federal law expanded to include additional provisions. Shortly after federal hate crime law was envisioned, proposals were made by representatives from the gay and lesbian movement to further differentiate hate crime victims by adding sexual orientation to the list of provisions in federal hate crime law. Through direct and sustained testimony in federal hearings, social movement organization representatives were able to bestow empirical credibility on the violence connected with this provision (i.e., antigay violence), just as the ADL and other social movement organizations previously bestowed empirical credibility on violence organized around race, religion, and ethnicity. After much heated debate, advocates for the inclusion of sexual orientation in hate crime law convinced legislators that the meaning of sexual orientation was more similar to than dissimilar from the meanings already attached to race, religion, and ethnicity insofar as all are core axes of systematic discrimination. By successfully engaging in these linking strategies, gay and lesbian movement activists and their allies proved crucial to the expansion of hate crime law to cover sexual orientation, despite the fact that sexual orientation has not been recognized as a legitimate provision in previous federal discrimination law.

Other provisions initially recommended for inclusion in the law, but not added to the bill prior to its passage, did not attract significant and sustained social movement mobilization in congressional hearings. Prior to the passage of the HCSA, for example, during hearings legislators made passing references to the possibility of including "octogenarians," "union members," "children," "the elderly," and "police officers" in hate crime law. In the absence of formal hearings on violence against these groups, however, there was never an opportunity for representatives from these groups to establish the empirical credibility of the problem as it pertains to their constituencies. Similarly, there was no opportunity for representatives of these groups to engage in the necessary claims making required to legitimate these provisions. As a result, provisions for these constituencies have not been written into federal hate crime law. U.S. Representative John Conyers Jr. acknowledged this facet of lawmaking in hearings on hate crime when he said,

The reason we did not include octogenarians who are assaulted is because there was no testimony that suggested that they ought to be, as awful as the crimes visited upon them are, and the reason we did not account for policemen killed in the line of duty, is that there was no request that they be separated out from the uniform crime statistics. (Cong. Rec. 11395 [1988]) 
For comparative purposes, an examination of the legislative history of gender as a provision in federal hate crime law reveals that later in the history of federal lawmaking around hate crime, the importance of collective action, as measured through the presence of social movement organizations at congressional hearings and in congressional debates, declined. Once a corpus of hate crime law was established and select provisions were cemented in law (i.e., race, religion, ethnicity, and sexual orientation), new provisions-in this case gender-were adopted without direct pressure applied by sustained mobilization from relevant social movement organizations and their representatives, and despite the fact that it was purposely excluded from law in the incipient stages of the lawmaking process.

Although there have been many federal hearings on hate crime that address violence against women, none of these hearings have been initiated or sustained by feminist social movement organizations. Instead, lawmakers simply incorporated gender into the existing framework of hate crime laws established in previous hearings, whereas feminist advocates-most notably representatives from the National Organization for Women and the Feminist Majority-gave testimony only after the imminent passage of the bill was predicted (Jenness \& Broad, 1997). This occurred without much fanfare and without relevant social movement organizations engaging in direct and sustained lobbying work. It was only possible because gender, like race, religion, and ethnicity, was already a standard subject of federal discrimination law.

Declining involvement of social movement organizations is also evident in the history of the disability provision. Disability was added to both the reauthorization of the HCSA, the original and final version of the HCSEA, and the current bill pending in Congress: the Hate Crimes Prevention Act (§ 1529). The changing character of the law along these lines occurred despite the fact that federal lawmakers have never held a hearing on violence directed at those with disabilities and no contestation occurred over this provision. Moreover, the official records of federal-level hate crime lawmaking reveal that representatives from the disabilities movement have yet to make an appearance and offer testimony related to federal hate crime legislation. Regardless, disabilities, and thus persons with disabilities, have found a home in hate crime legislation, albeit rather late in the history of lawmaking on hate crime. Here, too, this occurred in light of the fact that disability, like race, religion, and gender, was already a standard subject of federal discrimination law, in large part because of the earlier passage of the Americans With Disabilities Act in 1990 (Shapiro, 1993).

This history of status provisions included and excluded from federal legislation is instructive. Theoretically speaking, the pattern described above and summarized in Table 1 suggests that the effects of social movements on hate crime lawmaking are twofold. On one hand, those movements give rise to activist organizations that in turn generate the individuals who promote and publicize a particular reform and then testify before Congress and other legislative bodies. 
TABLE 1: Social Movement Organization (SMO) Mobilization and the Adoption of Select Status Provisions in Federal Hate Crime Law, 1985-1998

\begin{tabular}{|c|c|c|c|c|}
\hline \multirow{3}{*}{$\begin{array}{l}\text { SMO } \\
\text { Mobilization }\end{array}$} & \multicolumn{4}{|c|}{ Status Provision } \\
\hline & \multicolumn{2}{|c|}{ Proposed } & \multicolumn{2}{|c|}{ Adopted } \\
\hline & Early (pre-1990) & Late (post-1990) & Early (pre-1990) & Late (post-1990) \\
\hline Yes & $\begin{array}{l}\text { Race/religion/ } \\
\text { ethnicity, sexual } \\
\text { orientation }\end{array}$ & & $\begin{array}{l}\text { Race/religion/ } \\
\text { ethnicity, sexual } \\
\text { orientation }\end{array}$ & \\
\hline No & $\begin{array}{l}\text { Octogenarians, union } \\
\text { members, children, } \\
\text { elderly, police officers }\end{array}$ & $\begin{array}{l}\text { Gender, } \\
\text { disabilities }\end{array}$ & & $\begin{array}{l}\text { Gender, } \\
\text { disabilities }\end{array}$ \\
\hline
\end{tabular}

This activity affects which groups are visibly associated with an issue and, ultimately, which groups are included in the law. On the other hand, in many cases it is really not the mobilization around the specific issue that is crucial, especially once a policy approach is available and established. Later in the formation of a policy domain, the approach and the category of persons must merely be seen as compatible by policy makers (e.g., Does disability "fit" under the hate crimes rubric?). Yet, in order for this to happen, a movement must have been successful over the long term in laying claim to inclusion within these types of issues (e.g., equal rights and violence issues).

As social movement goals were translated into a legal and policy issue, the term hate crime was refocused and specified, resulting in changes in its fundamental nature. In addition to the expansion of the hate crime concept described above, it was necessarily reconstituted in universal terms as concrete groups such as Blacks, immigrants, and Jews were folded into more abstract categories such as race, national origin, and religion. In other words, as the concept was translated into legal discourse, hate crime became something that members of minority and majority groups-Blacks and Whites, homosexuals and heterosexuals, immigrants and natives, women and men—could potentially be victims of and were thus given equal protection under the law. Thus, the domain of the concept was expanded beyond the mere addition of new provisions.

\section{THE DIFFUSION OF HATE CRIME STATUTES}

As direct and sustained activism declined in importance with regard to shaping the concept, legislative institutions began to determine the precise rules and policies that would constitute the official definition of and response to the problem. The legislative arena subjected the concept to a new set of pressures that 
reshaped it once again. Here, we focus on the making and remaking of hate crime as a state-level statutory construct and, in so doing, ask a broader question about the formation of the policy domain: Once developed, how do legal concepts circulate, take shape, and become institutionalized across distinct, but interrelated, polities (i.e., states)?

As of 1999, criminal hate crime laws had passed in 41 states (Jenness \& Grattet, 2001; Soule \& Earl, 1999). These laws differ in important ways, however. They share the same core elements. In particular, they all create or enhance penalties for criminal behavior motivated by some combination of status categories, such as race, religion, national origin, sexual orientation, gender, and disability. As we describe below, variation in the distribution of status provisions is extensive, but patterned. In particular, the approach an individual state took was largely shaped by when it adopted a law. In other words, the timing of adoption strongly influenced the specific wording used and the content included. For example, hate crime laws have employed four different ways of characterizing the motivational requirement for conviction under the statute. Some states, such as New Hampshire and Rhode Island, use phrasing that requires prosecutors to show that an act was precipitated by "animus, hostility, maliciousness, or hatred." Such wording implies that a high degree of emotional intensity be behind the offense; thus, a prosecutor must demonstrate the particular subjective state(s) that motivated the crime to obtain a conviction. In contrast, other states, such as California and New York, employ more restrained language that only requires that the perpetrator have an "intent to harass and intimidate the victim." This too requires the prosecutor to demonstrate that the perpetrator intended (a mental state) to cultivate a sense of fear and intimidation (another mental state) in the victim. And, this too is a difficult requirement to meet. A third type of motivational phrasing contains the least stringent requirement for the prosecutor. Louisiana and Ohio, for example, simply require that the offense be committed "because of" race, religion, ancestry, and so forth. ${ }^{6}$

As Figure 3 shows, the employment of these phrasings is time dependent. Each of these phrasings was employed prior to 1983, reflecting little consensus in the initial wave of adoptions between 1977 and 1987. However, by 1990, two forms - the "because of" wording and "intent to harass or intimidate" wording began to emerge as the most popular. Finally, after 1993, the because of phrasing became the dominant form, with roughly half of the adopting states using such language. The event responsible for this development was the U.S. Supreme Court decision in Wisconsin v. Mitchell (1993), in which the Court upheld a statute that employed the because of formulation. This ensured that the least stringent form of motivational phrasing was increasingly deemed legitimate.

The process of convergence around a specific motivational phrasing reflects legislative dynamics that are well known to students of state policy making and the diffusion of innovations (Gray, 1973; Strang \& Meyer, 1993; J. L. Walker, 1969). Within the system of state governments, innovative policies evolve through a series of characteristic phases. The initial phase is characterized by a 


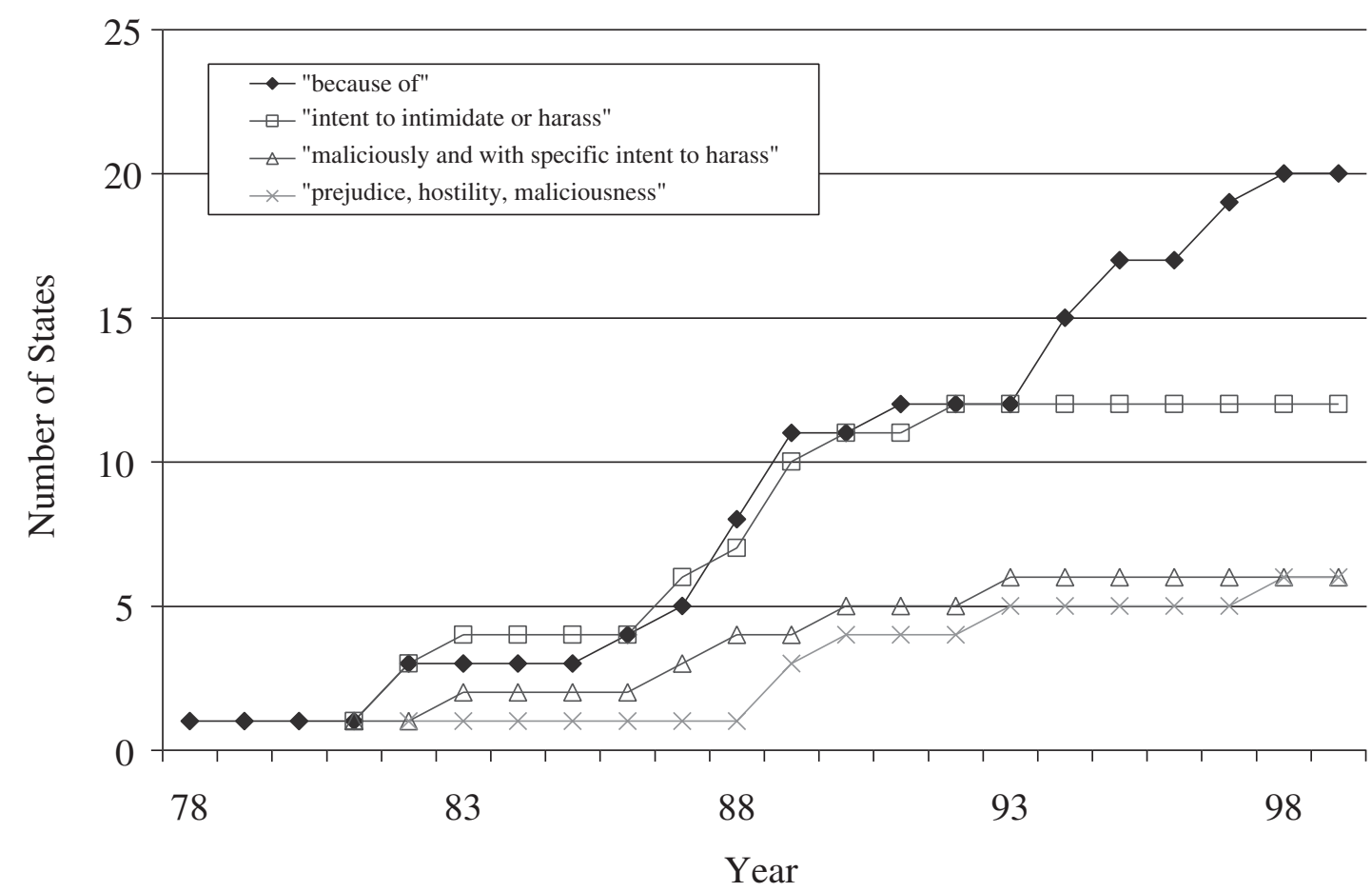

엉 Figure 3: Cumulative Frequency of Alternative Motivational Phrasings in Hate Crime Statutes, 1978-1999 
diversity of approaches because there are no clear models or guides on which to act. As time passes, other states begin to respond; however, they no longer operate in the absence of precedent and are instead confronted with various options and the experience of their predecessors about what works and what is a legitimate approach (e.g., constitutional or politically). Subsequent policy making results from informed mimicry of early innovators, which tends to lead to one or two approaches becoming understood as the best approach. In the aggregate, this means that a period of experimentation and diversity of approaches tends to be followed by a convergence, or homogenization, of approaches. As we have demonstrated above, hate crime law certainly follows this pattern of homogenization over its life course insofar as approaches to the law were once diverse but are increasingly convergent.

Despite the convergence in method of phrasing, however, hate crime statutes have become more expansive in terms of the categories of persons they cover. Figure 4 displays the status provisions included in the laws as of 1988 and then 10 years later in 1998. In both periods, nearly every state law in existence covered acts motivated by race, religion, color, and national ancestry. In 1988, only $11 \%, 21 \%$, and $26 \%$ of the statutes in existence included sexual orientation, gender, and disability, respectively. By 1998, however, half of the statutes had sexual orientation and disability and $40 \%$ had gender included. Figure 4 also makes apparent that many statutes now contain some miscellaneous categories that have not been replicated in any substantial way. Thus, three tiers emerge: categories that are always included, categories that are included with increasing regularity, and anomalous categories that are included but not with any regularity.

The interpretation of the pattern of status provisions over time is clear. The most pervasive categories reflect the oldest, most established, and most recognized axes of oppression. The salience of these categories reflects the success of the 1960s-era civil rights movement in galvanizing particular categories in the public consciousness and in legal discourse (Grattet et al., 1998). Legislators, by and large, do not contest the prevalence and seriousness of hate crime motivated by these categories (Jenness, 1999). Sexual orientation, gender, and disability reflect more recent, and therefore less embedded, rights movements that still face considerable opposition when claiming membership in issues such as hate crime (Jenness, 1999). Finally, the miscellaneous categories have little or no history to sustain claims for inclusion in the laws and therefore have made much less systematic inroads into the issue. ${ }^{7}$

Thus far, we have seen that the hate crime concept undergoes a common process within each new institutional arena into which it is placed. That is, its institutionalization is accompanied by a refocusing of the concept relative to constraints of each new arena into which it moves. Its meaning is sharpened and, as we have seen, expanded and elaborated in novel ways. Indeed, the twin processes that characterize the evolution of hate crime within the legislative arena, homogenization and expansion, are reiterated as the concept moves into the judicial realm. 

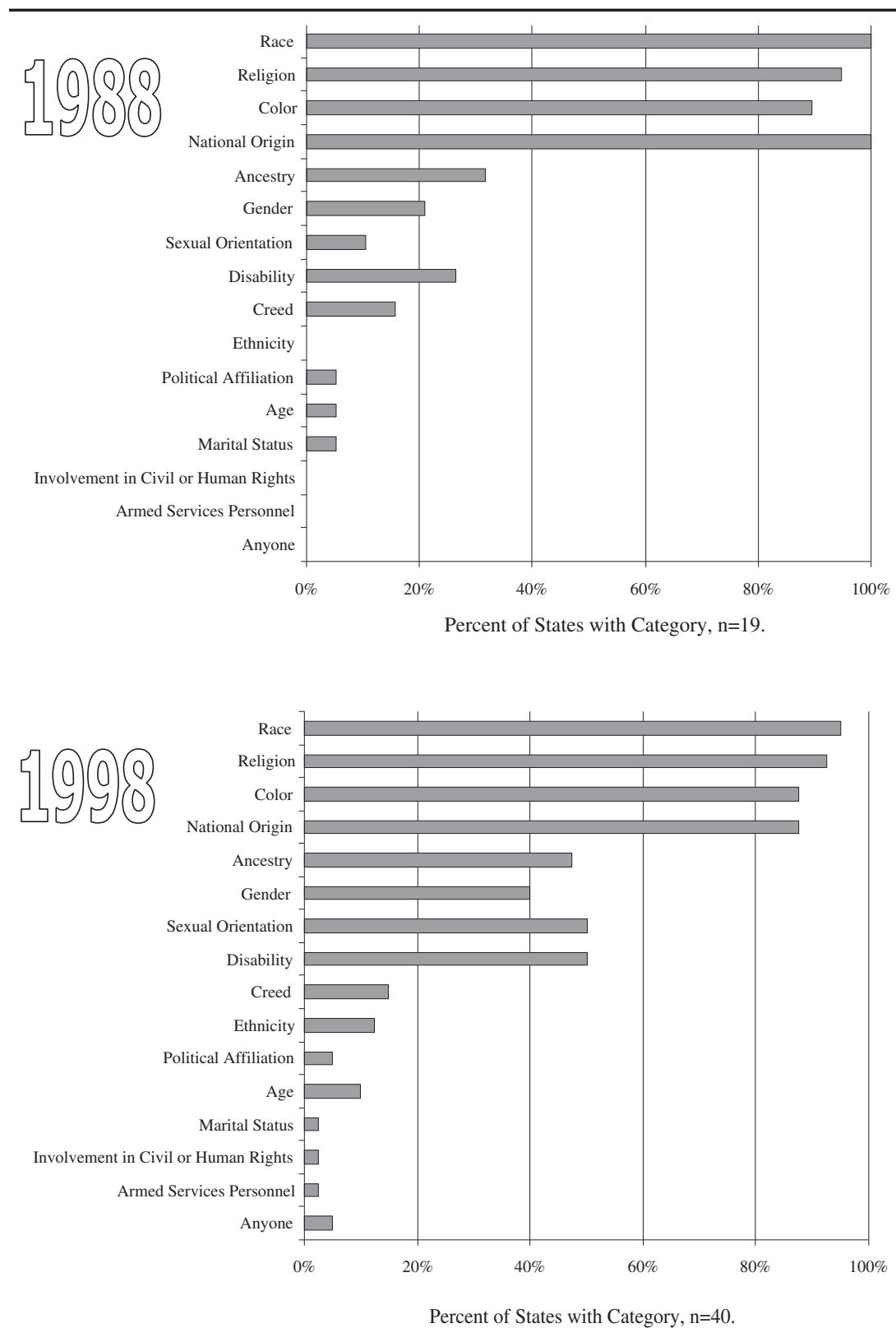

Figure 4: Status Provisions in State Hate Crime Laws, 1988 and 1998 


\section{THE RESTRICTION AND EXPANSION OF HATE CRIME IN APPELLATE CASES}

If legislatures provide the general templates for law, the job of courts, particularly appellate courts, is to flesh out the specific meanings of a statute. Between 1984 and 1998, U.S. appellate courts considered the constitutionality of hate crime statutes 38 times. ${ }^{8}$ As Figure 5 shows, the bulk of these cases occurred over a 3-year period stretching from 1992 to 1995. During this period, hate crime statutes were embroiled in a highly visible constitutional crisis (Bader, 1994; Brooks, 1994; Gaumer, 1994; Grannis, 1993; Kagan, 1992; Morsch, 1991; Strossen, 1993; Tribe, 1993; Winer, 1994). By 1997, however, that crisis was largely resolved, and the frequency of hate crime cases and attendant legal commentary subsided dramatically. This signals that the rules governing hate crime are becoming more "settled" in judicial discourse (Phillips \& Grattet, 2000).

Before being resolved, however, the constitutional crisis had important effects on the legal conception of hate crime. Namely, appellate judges rejected certain approaches and endorsed others, thus creating a jurisprudential foundation for the statutes. Although the statutes are themselves quite broad and potentially cover all sorts of things, courts have restricted their meaning in ways that result in the concept of hate crime becoming increasingly delineated and demarcated. A review of constitutional challenges reveals how this has occurred and with what consequence.

The central concern expressed by challengers of the statutes is whether laws punish speech. Indeed, First Amendment violations have been the most successful strategy in challenging specific statutory forms (R.A.V. v. Saint Paul, 1992; State v. Kearns, 1994; State v. Talley, 1993). This is not surprising given that almost all of the statutes cover activity that clearly borders on speech, such as intimidation and harassment. In response to these concerns, courts have consistently restricted the coverage of hate crime law to the "conduct" side of the speech-conduct continuum (Phillips \& Grattet, 2000). This has meant that intimidation and harassment can only refer to speech that involves direct threats. That is, a speech act must qualify as a "true threat," an established standard that requires demonstration that a speaker has both the intent and the capacity to carry out the threat. It is, in practical terms, a speech act verging on conduct. Racial epithets and taunts that do not meet the legal standard of true threats do not qualify as hate crime under this interpretation. Thus, the possible meanings of hate crime as covering, say, the conscious creation of an intimidating environment or general expressions of a desire to do violence to members of a particular group would be extremely difficult, if not impossible, to prosecute under the prevailing judicial interpretation of the laws.

In contrast to the restrictions implied by considerations of First Amendment violations, there are some identifiable ways in which the settling of the hate 


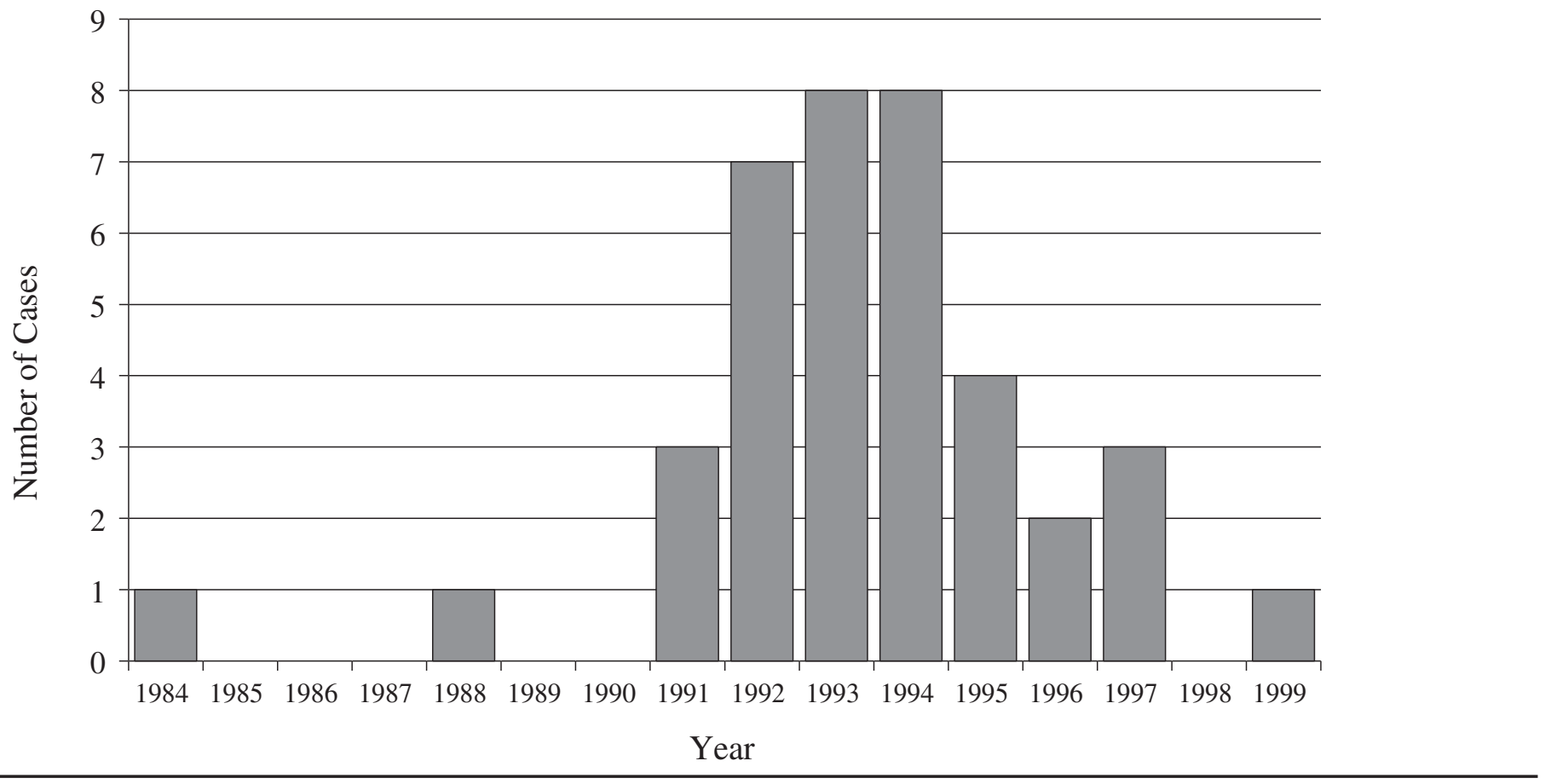

के Figure 5: Number of Appellate Cases Challenging Hate Crime by Year, 1984-1999 
crime concept in the hands of judges has led to an expansion of the domain of coverage. This is most evident through an examination of the way the motivational standard has been interpreted. As we detailed in the previous section, there is considerable diversity in terms of the ways statutes define the specific motivational requirements. The because of construction is relevant to the issue of whether hate crime laws punish speech, underlying motives, and political viewpoints. By endorsing the because of phrasing, courts maintain that it does not matter what political views or ideologies motivated the act. Rather, all that matters is that a victim was selected because of his or her race, religion, ancestry, and so forth, quite apart from the degree of malice involved on the part of the perpetrator (Phillips \& Grattet, 2000).

By endorsing the because of form of the law, courts drew a parallel with established antidiscrimination principles within which

it does not matter why a woman is treated differently than a man, a black differently than a white, a Catholic differently than a Jew; it matters only that they are. So also with section 775.085 [Florida's hate crime statute]. It doesn't matter that Dobbins hated Jewish people or why he hated them; it only mattered that he discriminated against Daly by beating him because he was Jewish. (Dobbins v. State, 1992)

This interpretation situates hate crime jurisprudence within the broader and more established body of antidiscrimination law; in so doing, it broadens its applicability by defining biased selection of the victim, rather than hate, as the requisite motivational precursor. The consequence is that acts by virulent racists or offenders with "only" a mild disrespect for the victim's group are punished equally, with an offender's underlying philosophy and degree of bigotry being irrelevant. In short, this expands the domain of the law because, properly speaking, "hate" is not a necessary element, only bias."

In sum, as hate crime statutes came under the scrutiny of the courts, yet another round of reworking of the concept was set in motion. As with the social movement and legislative arenas described earlier, a refocusing and sharpening of the concept resulted from the circulation of hate crime within courts. And once again, the institutionalization of hate crime is reflected in its refinement and the emergent consensus about what the laws cover and do not cover. The courts have had a unique influence insofar as judicial discourse regarding hate crime has framed the topic as discriminatory violence, in large part by subsuming it under antidiscrimination laws. In the process, its meaning was further delimited, and a range of circumstances was ruled outside of the domain of the concept. Most notably, the judicial translation of hate crime into bias crime has meant that hate crime law might be enforced in circumstances where hate is absent. The remaining question, then, is what happens to the concept once the law is legitimated by the courts and it is placed in the hands of law enforcers? 


\section{ENFORCING HATE CRIME LAWS}

If the efforts of legislators in responding to hate crimes peaked in the late 1980s and the court challenges played out mostly prior to 1995, then the late 1990s witnessed enormous attention to law enforcement—especially policing and prosecution - as the principal problem areas with respect to hate crime. At this point in the history of the concept, the legislative issues regarding who and what should be covered by the laws, as well as the judicial issues regarding the legitimacy and constitutionality of the laws, have given way to pragmatic issues about the organizational changes required to enforce the laws. Efforts along these lines are currently ongoing in federal, state, and local policing institutions. Indeed, law enforcement officials at federal (Reno, 1999), state (Lockyer, 1999), and local (Garcetti, cited in Boxall, 1998) levels have recently announced plans to redouble efforts at policy training and the enforcement of hate crime statutes.

Much of the social science research on hate crimes focuses on the multitude of ways police departments are responding to the legal mandate to pursue bias-motivated crime (Boyd, Berk, \& Hamner, 1996; Martin, 1996; S. Walker \& Katz, 1995; Wexler \& Marx, 1986). Conducted in the early 1990s when the precise definition of hate crime was still being negotiated in legislatures and courts, these early studies reveal that hate crime policing is quite variable across jurisdictions and across divisions within the same jurisdiction. In large part, this variation is attributable to differences in the philosophies, organizational structures, and routine practices in different departments, as well as the newness of the criminal category itself. Given that the latter is only a temporary condition, there is reason to believe that variation in the policing of hate crime is decreasing and will continue to do so as the concept becomes settled. Just as social movement activism, lawmaking, and judicial decision making around hate crime have done over the past two decades, newfound police practices related to hate crime are likely to become established and taken for granted. Indeed, preliminary evidence suggests this is the case. ${ }^{10}$

In recent years, efforts to formulate uniform police training guidelines have revolved around the Federal Bureau of Investigation's (FBI's) promotion of its own program (Reno, 1997, 1999). Large states such as California, for example, have revised and updated their police training guidelines to reflect changing definitions and judicial interpretations of the law and to bring their guidelines into alignment with the FBI's. In particular, our research on California shows that the FBI and the California guidelines are both aware of the judicial rulings relevant to the question of how to classify cases where bias is only one of several motivations. Reflecting recent court decisions in California, both sets of guidelinesCalifornia's and the FBI's - stipulate that an incident should be classified as a hate crime when it appears to have been caused "in whole, or in part" by race, 
religion, and so forth (Jenness \& Grattet, 2001). In other words, at both the state and federal levels, training is being altered to reflect the more recent conceptualization of hate crime law, with homogenization in policing policy and practice following suit.

Many California police departments have recently adopted general orders relative to hate crime. These orders articulate local department policies about hate crime, thus embodying law enforcement's response to the issue. They typically include a working definition of the concept, as well as a list of indicators reflecting the kinds of evidence that suggest a hate crime has occurred and a set of procedures for processing cases that might be classifiable as hate crimes. Since hate crime constitutes a relatively new criminal category for law enforcement, it is not surprising that the production and dissemination of these orders are a recent development.

In light of being handed this new crime to enforce, some police officers express complaints about the law, and others comply - to greater or lesser degreeswith the mandate to enforce it. With regard to the former, some officers register complaints that resemble those made in relation to domestic violence laws in the 1970s and 1980s and stalking laws in the 1990s. Namely, opponents argue that hate crime laws are hopelessly vague and too ambiguous to enforce; moreover, law enforcement personnel have more serious problems to contend with (S. Walker \& Katz, 1995). In contrast, Boyd et al. (1996) found out that many officers express the opposite view. They do not view the complexities of the categorization processes that surround the enforcement of hate crime as fundamentally different from other kinds of crimes and attendant required police work. In part, these contrasting views reflect the newness of the concept and the diversity of police practices and personnel in the United States.

The newness of the concept is further reflected in the variation in departmental general orders. For example, as Figure 6 shows, few of the general orders cite anything other than race, religion, and ancestry as relevant status provisions in their definitions of hate crime. These departments are operating with definitions of hate crime that date back to the early 1980s. This is even more surprising when we consider that California has one of the most expansive definitions of hate crime, including coverage of transsexuals and that all the authors of the order needed to do is read the statute to realize the categories of persons covered under the law. With such variations existing at the local level, it is not surprising that there is considerable diversity of interpretations.

From a social science point of view, classic and contemporary studies of policing demonstrate that variation in interpretative practices across departments and officers is not uncommon in law enforcement (Kitsuse \& Cicourel, 1963; Saunders, 1977). Officers frequently deal with circumstances that are difficult to classify and require them to understand complex motivations and the interpersonal dynamics of the persons involved. Thus, the question that must be asked about hate crime is, Does the variation we currently see correspond to other innovations in crime policy at this stage of their development? In other 

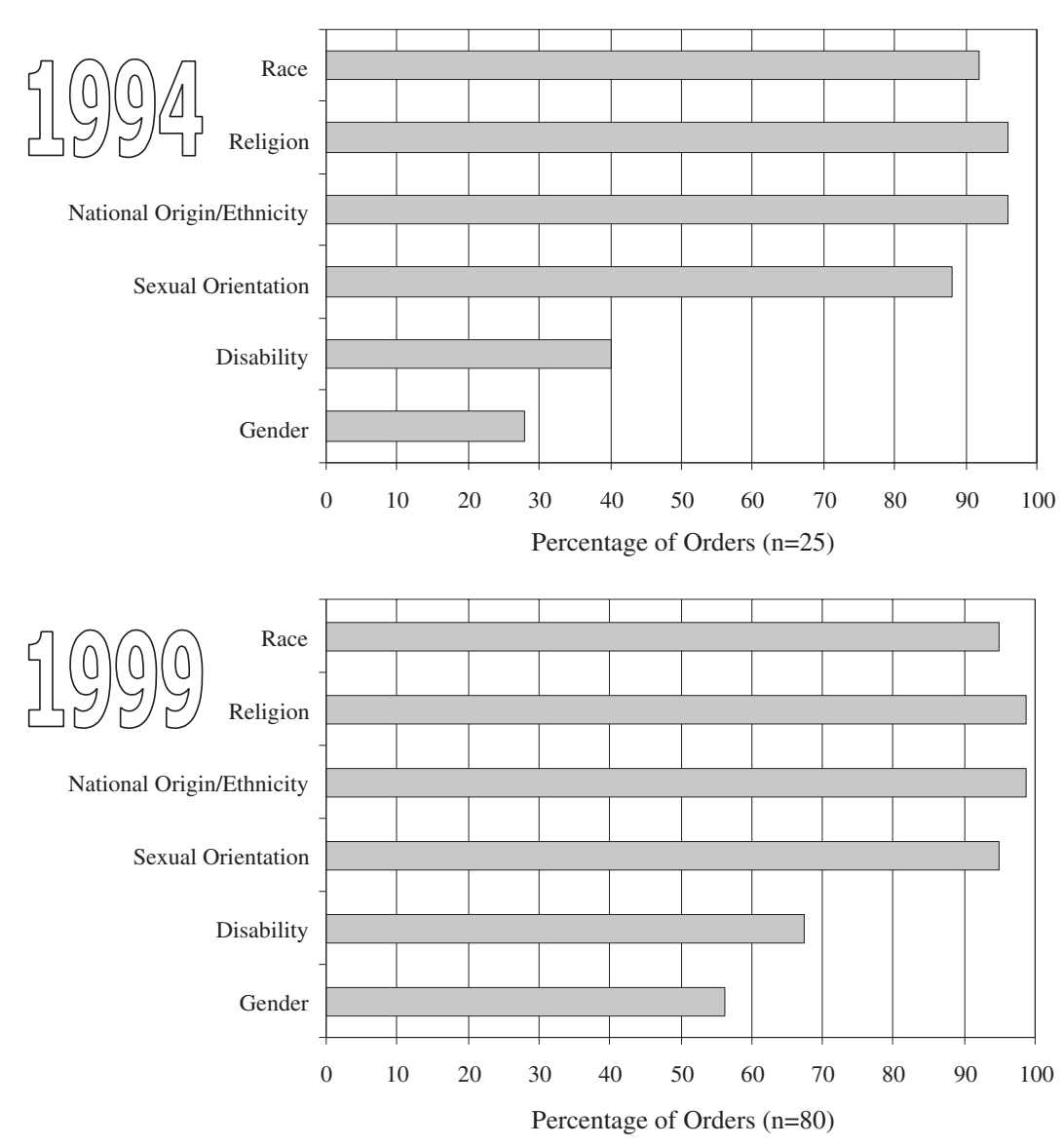

Figure 6: Inclusion of Particular Status Provisions in California Police Department General Orders Regarding Hate Crimes, 1994 and 1999

words, the appropriate comparison for hate crime policing is not crimes such as theft, which is a deeply settled concept in American law and police practice and thus raises comparatively little disagreement about its behavioral attributes, but stalking, domestic violence, and sexual harassment, all of which are recent innovations, like hate crime, that have become increasingly settled in law enforcement practice.

The other side of law enforcement, the prosecution of hate crime, is in roughly the same shape. Prosecutors express mixed opinions about the viability and value of enforcing hate crime law. Some prosecutors have gone on record rejecting hate crime laws as useless and unenforceable (Jacobs \& Potter, 1998), 
whereas others have strongly embraced them as a meaningful response to community strife (Boxall, 1998). With regard to the former, at least in the abstract, hate crime implies greater evidentiary burdens, more effort to spell out the intricacies of the law to juries, and more time and energy to prepare cases. For prosecutors who are understaffed and subjected to heavy caseloads, such laws may represent an extra set of burdens they prefer to avoid in an occupation where one's work is usually evaluated in terms of conviction rates. Other prosecutors, however, view hate crime laws as an extra tool to contribute to the management of crime and intergroup conflict in their community.

Although there is currently little published social science research on hate crime prosecution to draw conclusions about which of these predominates among American prosecutors, the publication of initial statistics on hate crime prosecutions, convictions, and plea bargains is revealing. In particular, four recent years of data on prosecution in California begin to tell the story (see Figure 7). From 1995 to 1998, all of the major indicators of the hate crime processing have varied. Only about 6\% of hate crime incidents in 1995 and 1996 led to successful convictions. In 1997, that figure rose to more than 17\%, but in 1998 it fell back to $10 \%$. On the surface, these percentages may seem dismal. However, to put these percentages in perspective, consider that the more recently reported percentages fall between the percentages for aggravated assault (a crime known for being comparatively easy to police and prosecute) and vandalism (a crime known for being fairly difficult to police and prosecute). Of course, hate crime runs the gamut from assault to vandalism, so it is not surprising that it is somewhere between the two in terms of the ratio of incidents to convictions. However, these data only tell us about the slippage between the police's classification of incidents and the ability of prosecutors to obtain convictions.

A more useful way of evaluating prosecution is to determine the proportion of cases that, once filed by the prosecutors, leads to convictions. Although there is again a lot of variability, in general, the ratio has improved and falls within the range of other crimes. This suggests that once prosecutors decide to proceed to prosecute a crime as a hate crime, they do not seem to be struggling greatly with obtaining convictions, at least not any more so than with other crimes. This evidence contradicts arguments about the unenforceability of hate crime law. A final piece of evidence worth contemplating is guilty pleas. If, as some have contended (Jacobs \& Potter, 1998), hate crimes are considerably more ambiguous and contestable than "parallel crimes" (Lawrence, 1999) and thus a misuse of justice system resources, then we would expect that plea bargains rarely happen. Defendants would be encouraged to challenge the charge on constitutional or evidentiary grounds. However, as is the case with most crimes, the majority of hate crime cases result in guilty pleas rather than trials, and that number has increased in recent years.

Thus, the pessimistic view of hate crime prosecutions as causing enormous problems for prosecutors is simply not borne out by initial available evidence. Although only a small portion of incidents produces convictions, when 


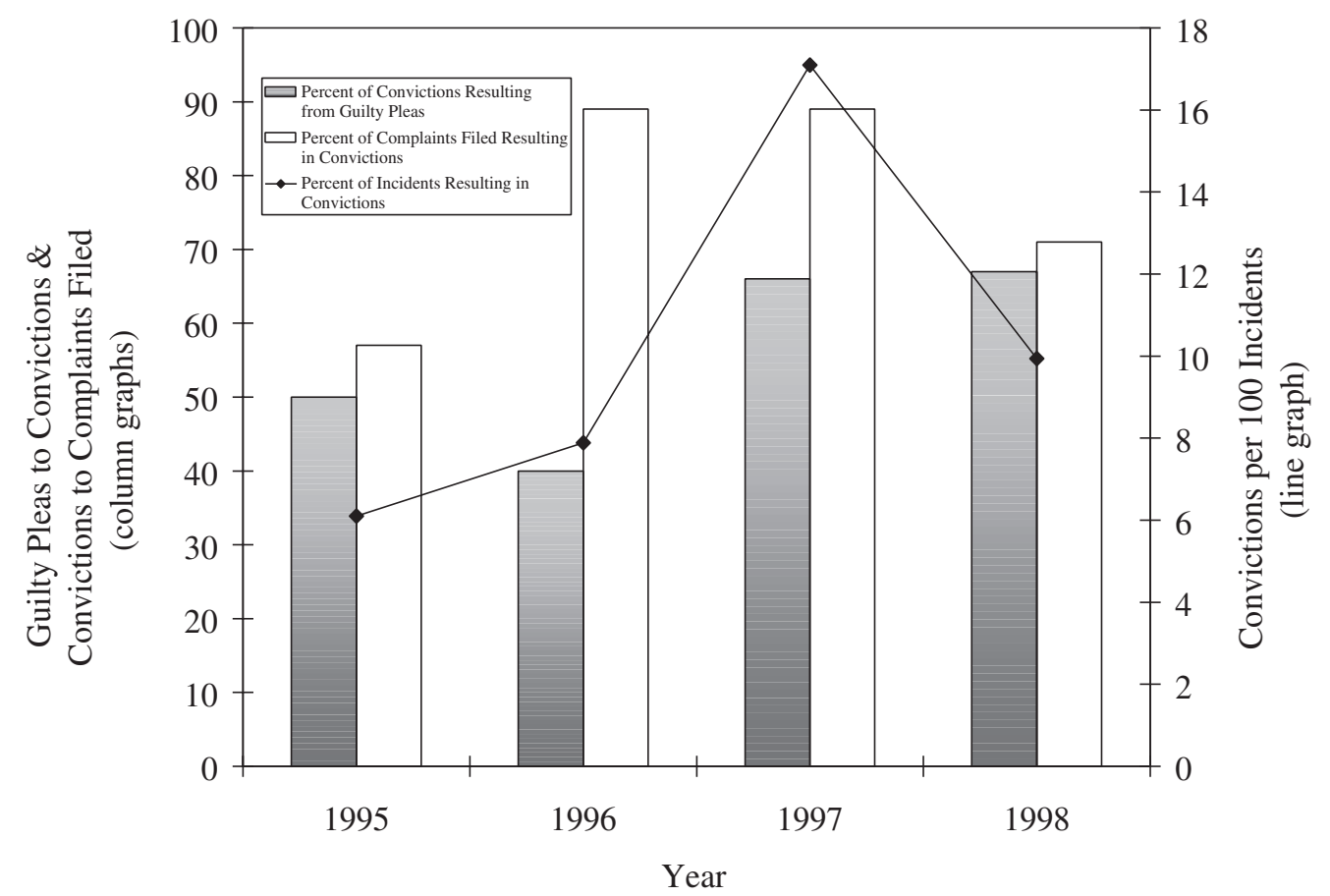

Figure 7: California Prosecution Data on Hate Crime, 1995-1998 
prosecutors do decide to file cases as hate crimes they are successful in obtaining convictions, usually by guilty plea. This suggests that the prosecution of hate crime is proceeding in a conservative rather than liberal or indiscriminate fashion, something we would expect from a newly initiated policy. Moreover, hate crime prosecutions are beginning to resemble patterns for other crimes, something we would expect to be increasingly the case as the concept becomes more and more settled in the law enforcement arena.

In theoretical terms, law enforcement represents the end point of the movement of the hate crime concept across the various policy arenas we have discussed. It should not be surprising that it is less institutionalized than the other arenas. Nonetheless, although evidence is only recently beginning to be compiled, it appears that - as in the legislative and judicial realms - the process of settling of the concept hate crime is occurring within law enforcement. Thus, across the different arenas in which hate crime policies have been defined, we observe a striking similarity in core social processes. Taking these processes seriously has implications for how hate crime statistics are understood, where future social science research might focus next, and what the future might hold for hate crime policy making.

\section{DISCUSSION AND CONCLUSION}

Over the past three decades, hate crime has been defined, promoted, and addressed as a contemporary social problem. As Senator Edward Kennedy proclaimed,

Civil rights are still the unfinished business of America. Hate crimes are uniquely destructive and divisive, because their impact extends far beyond the victim. They poison entire communities and undermine the ideals for which America stands. They deserve to be punished with the full force of law. (cited in Lawrence, 1999, jacket note)

Interestingly, it was not until the end of the 20th century that comments like this were expressed by senior elected officials and that policy reform designed to combat discriminatory violence was forthcoming and institutionalized. This marks an important moment in the history of crime control efforts, the development of criminal and civil law, the allocation of civil rights, and the symbolic status of select minorities in the United States. So, it is fair to ask, How have the many changes that accompany this moment come about such that an entirely new policy domain has emerged to redefine age-old conduct-discriminatory violence-as a crime problem? From our point of view, an answer to this question necessarily forms the backdrop against which the behavior and consequences of hate crime can best be understood by social scientists and addressed by activists, policy makers, and citizens. 
As the above discussion illustrates, the birth and structuring of the hate crime policy domain have occurred as a sequence of stages. In its journey from social movement frame to legislative concept to judicial theory to law enforcement practice, the meaning and policy significance of hate crime have undergone a series of transformations. As we have seen, each change reflects the unique demands placed on the concept in the different institutional arenas that compose the American policy process. Its meaning has been pushed and pulled in new directions both within and across each new context, mutating in ways that ensure constancy as well as innovation.

As the policy concept circulates within and across institutional spheres, common social processes operate. Specifically, within each arena hate crime begins as an imprecise multivalent concept whose definition and attendant policy implications become more refined and settled over time. This settling takes two seemingly contradictory paths, each of which reflects countervailing forces evident within select institutional spheres as well as between these spheres. On one hand, the concept becomes more specified and restricted in terms of the circumstances under which it is applicable. That is, it becomes possible to rule out certain behaviors and circumstances from the domain of the concept. On the other hand, the concept becomes more embedded and more established. As it is increasingly applied in novel circumstances, its definition expands as new phenomena are assembled under its rubric. Even the process by which a broader foundation or framework is sought can result in enlarging the meaning and implication of the concept. Finally, it is important to understand that the core features of this process - the sequential formation of a policy domain, the solidification of the definition of the policy concept, and its institutionalization occurring both through expansion and restriction of its scope - are not unique to hate crime. Indeed, these are characteristics of policy domain formation processes more generally.

With these understandings in mind, it is possible to confront some of the major criticisms of hate crime policy. A central concern has been that hate crime is by definition a highly subjective and vague concept and therefore will lead to resource waste as officials strain to determine how best to implement the laws. This research suggests that the ambiguity of the concept is decreasing over time in all of the spheres we have examined. Specifically, social movement players have generally reached agreement on how to operationalize the concept. A dominant model of hate crime has emerged in the legislative arena. Judicial interpretations of the law have largely converged. And, the law enforcement practices appear to be solidifying. Within this context, to critique a concept because it appears ambiguous to some officials amounts to a critique of the concept's newness, which, in our view, is not a particularly compelling basis for critique.

The questions raised by this phenomenon are not whether a concept is hopelessly ambiguous, but rather, what features of the social organization of various sectors of the legal system influence variation in understandings and uses. Thus, 
the vagueness of the concept of hate crime must be analyzed longitudinally rather than concluded from a static impression gathered early in the career of a concept. Likewise, comparison cases are extremely important to evaluating hate crime laws. There is heterogeneity in the interpretation of many kinds of laws. The question should not be "Do understandings of hate crime vary across jurisdictions?" but "How does the variability in hate crime compare with other crimes?" To address this question, the comparison case should not be crimes such as assault or burglary, whose meaning and associated policing practices have been institutionalized for centuries. Instead, hate crime should be compared with categories of law, such as sexual harassment, stalking, and domestic abuse, which are comparatively new categories that have traveled the same path from social movement construct to law enforcement tool.

A similar response is appropriate to the critique of hate crime statistics. Because the statistics are so contingent on the part of the hate crime policy domain that is the least institutionalized (i.e., policing), data collection remains problematic in the pursuit of evaluating the extent and character of hate crime in the United States. But, this should not be the final judgment. In fact, given the efforts to improve the knowledge of law enforcement and to homogenize the data collection techniques currently under way by federal and some state law enforcement agencies, we expect data collection to become more systematic and reliable and, incidentally, more useful for traditional criminological analyses as well. Certainly, this has been the case with other recently invented, diffused, and institutionalized categories of crime, such as stalking.

Finally, the policy implications that derive from this analysis are simple. Programs that are designed to facilitate the transfer of knowledge and techniques to prosecutors and police officers are precisely what will hasten the institutionalization process we have discussed. Cautious prosecution is also advisable, not only because case-building strategies and expertise are at an early stage of development but also because the symbolic value of prosecuting cases as hate crimes diminishes with volume and with particular controversial applications. Ironically, hate crimes may be a kind of law that we would not want to see implemented with great regularity. The more it is applied, the more "normalized" hate crimes become, and what was once front-page news slips to the third page of the metro section. The symbolic force of law diminishes as a result.

\section{NOTES}

1. Other terms have been used to describe much the same combination of cultural and organizational elements of political processes (e.g., "policy areas" [Amenta \& Carruthers, 1988, p. 666], "sectors" [Freeman, 1985; W. R. Scott \& Meyer, 1983, p. 137], "subsystems" [Freeman, 1985], "issue domains" [McDonagh, 1989, p. 121], "fields" [Grattet, 1994, p. 15], and "programs" [Rose, 1985, p. 9]).

2. Recognizing that policy domains are rooted in social constructions does not, however, mean that the social conditions they address are not real or, by extension, that the social facts and attendant 
suffering underlying a problem are only illusory. Rather, it merely acknowledges that how problems are defined and responded to are contingent on available frameworks of meaning that are appropriated and deployed in key institutional settings.

3. In the context of waning legislative support for progressive civil rights-based movements in the early 1980s, enhancing punishments for hate crimes could be justified as part of the larger "get tough on crime" campaign. Under this rubric, it was difficult for conservative policy makers to oppose it. Wittingly or not, hate crime law advocates capitalized on an era in American policy making in which it would be difficult for members of either party to vote against crime legislation promoted by various sectors of the anti-hate crime movement.

4. Establishing empirical credibility for a social problem is crucial to the development of a policy domain. Claims are empirically credible "to the extent that there are events and occurrences that can be pointed to as documentary evidence" (Snow \& Benford, 1992, p. 140).

5. The Coalition on Hate Crimes was composed of civil rights, religious, ethnic, and law enforcement groups, as well as a diverse array of professional organizations, including the AntiDefamation League, the American Bar Association, 30 attorneys general, the National Institute Against Prejudice and Violence, the National Gay and Lesbian Task Force, the American Psychological Association, the American Psychiatric Association, the Center for Democratic Renewal, the American Civil Liberties Union, the American Jewish Congress, People for the American Way, the National Organization of Black Law Enforcement Executives, the U.S. Civil Rights Commission, the Police Executives Research Forum, the Criminal Justice Statistics Administration, the International Association of Police Chiefs, the National Council of Churches, the National Coalition of American Nuns, and the American Arab Anti-Discrimination Committee.

6. Although technically speaking these phrasings suggest different requirements for prosecutors, appellate courts have tended to view them as meaning the same thing (Phillips \& Grattet, 2000).

7. Paralleling the pattern of growth in status provisions, there is a similar pattern of growth in the kinds of activities referenced in hate crime statutes (Grattet, Jenness, \& Curry, 1998). As the laws diffused, states began to expand the range of covered crimes from assault, vandalism, and intimidation to blocks of crimes (e.g., felonies), and more recently, some states have even passed laws that permit any crime to be converted into a hate crime (e.g., Vermont).

8. This refers only to cases considering the "facial validity" of hate crime laws. Cases involving constitutionality challenges based on how the laws were applied (i.e., "as applied" challenges) are not included here because the latter deal with case-specific circumstances of enforcement and application rather than the more general jurisprudential questions that constitute our focus.

9. Incidentally, this is also why many scholars suggest a terminology shift such that the subject and the laws should be referred to as "bias crime" rather than "hate crime."

10. As envisioned in Figure 1, law enforcement falls in the last phase of the formation of the hate crime policy domain; thus, it is the institutional sphere on which we have the least amount of valid and reliable data. Accordingly, in this section, we are left to hypothesize to a greater extent than in previous sections.

\section{REFERENCES}

Amenta, E., \& Carruthers, B. (1988). The formative years of U.S. social spending polices. American Sociological Review, 53, 661-678.

Bader, H. F. (1994). Penalty enhancement for bias-based crimes. Harvard Journal of Law and Public Policy, 17, 253-262.

Bensinger, G. (1992). Hate crimes: A new/old problem. International Journal of Comparative and Applied Criminal Justice, 16, 115-123.

Boxall, B. (1998, February 13). D.A. seeks to expand hate crimes unit. Los Angeles Times, B3. 
Boyd, E., Berk, R., \& Hamner, K. (1996). Motivated by hatred or prejudice: Categorization of hate-motivated crimes in two police divisions. Law \& Society Review, 30, 819-850.

Brooks, T. D. (1994). First Amendment-penalty enhancement for hate crimes: Content regulation, questionable state interests and non-traditional sentencing. Journal of Criminal Law and Criminology, 84, 703-742.

Burstein, P. (1991). Policy domains: Organization, culture, and policy outcomes. Annual Review of Sociology, 17, 327-350.

134 Cong. Rec. H 3373, No. 70 (May 18, 1988). Hate Crime Statistics Act. 100th Congress, 2nd session.

DiMaggio, P., \& Powell, W. W. (1983). The iron cage revisited: Institutional isomorphism and collective rationality in organizational fields. American Sociological Review, 48, 147-160.

Dobbins v. State, 605 So. 2d 922 (Fla. App. 1992), LEXIS 10062, 17 Fla. Law W. D 2222 (1992).

Fishman, M. (1978). Crime waves as ideology. Social Problems, 25, 531-543.

Freeman, G. P. (1985). National styles and policy sectors: Explaining structured variation. Journal of Public Policy, 5, 467-496.

Gaumer, C. P. (1994). Punishment for prejudice: A commentary on the constitutionality and utility of state statutory responses to the problem of hate crimes. South Dakota Law Review, 39, 1-48.

Goldberg, R. A. (1991). Grassroots resistance: Social movements in the twentieth century. Belmont, CA: Wadsworth.

Grannis, E. J. (1993). Fighting words and fighting freestyle: The constitutionality of penalty enhancement for bias crimes. Columbia Law Review, 93, 178-230.

Grattet, R. (1994). At play in the field of the law: Professionals and the transformation of industrial accident law. Unpublished dissertation manuscript.

Grattet, R., Jenness, V., \& Curry, T. (1998). The homogenization and differentiation of hate crime law in the United States, 1978-1995: Innovation and diffusion in the criminalization of bigotry. American Sociological Review, 63, 286-307.

Gray, V. (1973). Innovation in the states: A diffusion study. American Political Science Review, 67, 1174-1185.

Jacobs, J., \& Potter, K. (1998). Hate crimes: Criminal law \& identity politics. New York: Oxford University Press.

Jenness, V. (1995). Social movement growth, domain expansion, and framing processes: The gay/ lesbian movement and violence against gays and lesbians as a social problem. Social Problems, 42, 145-170.

Jenness, V. (1999). Managing difference and doing legislation: Social movement mobilization, categorization processes, and identity politics in the making of hate crime law in the U.S., 1985-1997. Social Problems, 46, 548-571.

Jenness, V., \& Broad, K. (1997). Hate crimes: New social movements and the politics of violence. Hawthorne, NY: Aldine de Gruyter.

Jenness, V., \& Grattet, R. (1996). The criminalization of hate: A comparison of structural and polity influences on the passage of "bias-crime" legislation in the United States. Sociological Perspectives, 39, 129-154.

Jenness, V., \& Grattet, R. (2001). Making hate a crime: From social movement to law enforcement. New York: Russell Sage.

Kagan, E. (1992). The changing faces of first amendment neutrality: R.A.V. v. St. Paul, Rust v. Sullivan, and the problem of content-based underinclusion. Supreme Court Review, 2, 29-77.

Kitsuse, J., \& Cicourel, A. (1963). A note on the uses of official statistics. Social Problems, 11, 131.

Lawrence, F. M. (1999). Punishing hate: Bias crimes under American law. Cambridge, MA: Harvard University Press.

Lockyer, B. (1999, August 16). Announcement of Civil Rights Commission and rapid response protocol for combating hate crimes [Press release]. Sacramento: State of California, Attorney General's Office. 
Maroney, T. A. (1998). The struggle against hate crime: Movement at a crossroads. New York University Law Review, 73, 564-620.

Martin, S. (1996). Investigating hate crimes: Case characteristics and law enforcement responses. Justice Quarterly, 13(3), 455-480.

Mauss, A., \& Jenness, V. (2001). Social problems. In E. Borgatta \& M. Borgatta (Eds.), The encyclopedia of sociology (pp. 2759-2766). New York: Macmillan.

McAdam, D. (1982). Political process and the development of Black insurgency. Chicago: University of Chicago Press.

McDonagh, E. L. (1989). Issues and constituencies in the progressive era: House roll call voting on the Nineteenth Amendment, 1913-1919. Journal of Politics, 51, 119-136.

Meyer, J. W., \& Rowan, B. (1977). Institutional organizations: Formal structure as myth and ceremony. American Journal of Sociology, 83, 340-363.

Minkoff, D. C. (1995). Organizing for equality: The evolution of women's and racial-ethnic organizations in America, 1955-1985. New Brunswick, NJ: Rutgers University Press.

Morris, A. D. (1984). The origins of the civil rights movement: Black communities organizing for change. New York: Free Press.

Morsch, J. (1991). The problem of motive in hate crimes: The argument against presumptions of racial motivations. Journal of Criminal Law and Criminology, 82, 659-689.

Phillips, S., \& Grattet, R. (2000). Judicial rhetoric, meaning making, and the institutionalization of hate crime. Law and Society Review, 34(3), 567-606.

Powell, W. W., \& DiMaggio, P. J. (Eds.). (1991). The new institutionalism in organizational analysis. Chicago: University of Chicago Press.

R.A.V. v. Saint Paul, 505 U.S. 377; 112 S. Ct. 2538; 1992 U.S. LEXIS 3863; 120 L. Ed. 2d 305; 60 U.S.L.W. 4667; 92 Cal. Daily Op. Service 5299; 92 Daily Journal DAR 8395; 6 Fla. Law W. Fed. S 479 (1992).

Reno, J. (1997). Memo: Implementation of hate crime initiative [U.S. Department of Justice, Attorney General memo] [Online]. Available from: http://www.usdoj.gov/ag/readingroom/ ag_foia1.htm

Reno, J. (1999, March). FY 2000 summary performance plan Section 3.1.1. Hate crimes [U.S. Department of Justice, Office of Attorney General] [Online]. Available from: http:// www.usdoj.gov/ag/summary/part1.htm

Rose, R. (1985). The programme approach to the growth of government. British Journal of Political Science, 15, 1-28.

Rovella, D. E. (1994, August). Attack on hate crime is enhanced. National Law Journal, 29 , A1.

Saunders, W. (1977). Detective work: A study of criminal investigations. New York: Free Press.

Scott, R. (1987). The adolescence of institutional theory. Administrative Science Quarterly, 32, 493-511.

Scott, W. R., \& Meyer, J. W. (1983). The organization of societal sectors. In J. W. Meyer \& W. R. Scott (with B. Rowan \& T. E. Deal) (Eds.), Organizational environments. Beverly Hills: Sage.

Shapiro, J. P. (1993). No pity: People with disabilities forging a new civil rights movement. New York: Random House.

Snow, D. A., \& Benford, R. D. (1992). Master frames and cycles of protest. In A. C. Morris \& C. McClurg Mueller (Eds.), Frontiers in social movement theory (pp. 133-155). New Haven, CT: Yale University Press.

Soule, S., \& Earl, J. (1999, August). All men are created equal: The differential protection of minority groups in hate crime legislation. Paper presented at the annual meeting of the American Sociological Association, Chicago.

State v. Kearns, 136 N.J. 56; 642 A.2d 349; 1994 N.J. LEXIS 430; 63 U.S.L.W. 2015 (1994).

State v. Talley, 122 Wash. 2d 192; 858 P.2d 217; 1993 Wash. LEXIS 227 (1993).

Strang, D., \& Meyer, J. W. (1993). Institutional conditions for diffusion. Theory and Society, 22, 487-512. 
Strossen, N. (1993). Yes: Discriminatory crimes. ABA Journal, 79, 44

Tribe, L. (1993). The mystery of motive, private and public: Some notes inspired by the problems of hate crime and animal sacrifice. Supreme Court Review, 1, 1-36.

Vaid, U. (1995). Virtual equality: The mainstreaming of gay \& lesbian liberation. New York: Anchor Books.

Walker, J. L. (1969). The diffusion of innovations among the American states. American Political Science Review, 63, 880-897.

Walker, S., \& Katz, C. M. (1995). Less then meets the eye: Police department bias-crime units. American Journal of Police, 14, 29-48.

Weed, F. (1995). Certainty of justice: Reform in the crime victim movement. New York: Aldine.

West, C. (1993). Race matters. Boston: Beacon.

Wexler, C., \& Marx, G. T. (1986). When law and order works: Boston's innovative approach to the problem of racial violence. Crime \& Delinquency, 32, 205-223.

Winer, A. S. (1994). Hate crimes, homosexuals, and the Constitution. Harvard Civil Rights-Civil Liberties Law Review, 29, 387-438.

Wisconsin v. Mitchell, 113 S. Ct. 2194; 1993 U.S. LEXIS 4024; 124 L. Ed. 2d 436; 61 U.S.L.W. 4575; 21 Media L. Rep. 1520; 93 Cal. Daily Op. Service 4314; 93 Daily Journal DAR 7353 (1993).

Zucker, L. G. (1991). The role of institutionalization in cultural persistence. In W. W. Powell \& P. J. DiMaggio (Eds.), New institutionalism in organizational analysis (pp. 83-107). Chicago: University of Chicago Press. 


\title{
Consequences for Victims
}

\author{
A Comparison of Bias- and Non-Bias-Motivated Assaults
}

\author{
JACK MCDEVITT \\ JENNIFER BALBONI \\ Center for Criminal Justice Policy Research, \\ Northeastern University \\ LUIS GARCIA \\ Suffolk University
}

JOANN GU

Boston Police Department

\begin{abstract}
There has been a great deal of scholarly and practical discussion regarding treating bias crimes as separate and distinct incidents. Critics assert that bias crimes are not inherently different from comparable nonbias offenses and that the consequences for victims are similar. This study presents findings from an analysis of survey data obtained from bias and nonbias assault victims from the city of Boston. Although there are several limitations to the authors' data, findings from the respondents replicate prior empirical research and indicate that bias crime victims experience more severe psychological sequelae, for a longer period of time, than victims of similar nonbias offenses. Specifically, the level of intrusive thoughts, feelings of safety, nervousness, and depression were all significantly higher for bias crime victims.
\end{abstract}

In the impassioned debate about hate crime legislation, assertions are made on both sides about the consequences of bias-motivated crimes on their victims. In one camp, several scholars claim that bias crimes are a political construct, devised to promote identity politics. Critics argue that distinguishing hate crime from other comparable crimes is superfluous because the bias motivation of the offender does not cause additional injurious impact on the primary victim. Implicit in this assumption is that bias crimes are not intrinsically different from similar nonbias offenses. Legal scholars Jacobs and Potter (1998) cogently summed this argument: "We do not believe that crimes motivated by hate

Authors' Note: This project was sponsored through the National Institute of Justice, Grant \#97-IJCX-0011. Points of view or opinions in this article are those of the authors and do not necessarily represent the official position of the funding source. The authors wish to thank Michael Buerger for his very insightful, helpful comments on this article.

AMERICAN BEHAVIORAL SCIENTIST, Vol. 45 No. 4, December 2001 697-713

(C) 2001 Sage Publications 
invariably are morally worse or lead to more severe consequences for the victims than the same criminal act prompted by other motivations" (p. 147). Critics cite the example that a bias murder victim is just as dead as a nonbias murder victim as a reason for treating these crimes similarly.

Although the no additional injury argument is based on apparently rational arguments, no empirical evidence is available to support it. Furthermore, this assumption about the differences between murder victims is misleading because, among other things, it does not address the fact that the overwhelming majority of bias crimes in this country involve intimidation, vandalism, or assault, not murder (Uniform Crime Reports, Hate Crime Reports, 1998). Most people readily would agree that a cross burning is different from a typical trespassing/vandalism offense. In this article, we focus on differences between bias and nonbias crimes in terms of their impact on assault victims, differences that have not been fully explored in prior research. This article reports the findings of our analysis of survey data from bias and nonbias assault victims regarding the psychological consequences of their victimization experiences.

\section{DIFFERENCES BETWEEN BIAS AND NONBIAS OFFENSES}

We posit that hate crimes are inherently more harmful to the social fabric of society than comparable crimes without bias motive. Several authors have suggested dimensions of bias crimes that may increase the impact these crimes would have on their victims. The first unique dimension of bias crimes is the aspect of victim interchangeability inherent in many of these crimes (Levin \& McDevitt, 1993). Interchangeability means that any individual who possesses, or is perceived to possess, a specific trait could be selected as a target. Bias crime victims are selected for victimization because of some actual or perceived status that they are powerless to change. For instance, an African American person can not change his or her race after an attack to prevent future victimization; he or she will continue to be African American.

The second unique dimension of bias crime is the capacity for secondary victimization. Bias crime offenders generally intend for their acts to reach far beyond the primary victim, to affect all members of a particular minority group. For example, a cross burning not only affects the immediate family, but any African American who becomes aware of the incident. Consider the differences in the following scenarios:

1. A teenage couple demonstrates their undying love by spray painting "Joe loves Mary" across the back wall of their community high school.

2. A hate monger professes his views of Nazism by spraying "Hitler was right" on a local synagogue.

Technically, both incidents are vandalism. The first scenario presents somewhat of a petty nuisance, whereas the second incident attacks a distinct segment of the 
population - attempting to intimidate a segment of the community by indicating approval of the annihilation of that group and signaling to all people of Jewish descent that the offender believes they are inferior. It would be difficult to argue that the racial slur does not victimize more people, in a more serious fashion, than the teenagers' prank in the first scenario.

Moreover, the effects of victim interchangeability and secondary victimization can interact to disrupt the community in serious and often violent ways. The U.S. Supreme Court referred to this dimension of bias crime as "the distinct emotional harm" that such crimes inflict, noting the potential to "incit[e] community unrest" (Wisconsin v. Mitchell, 1993). Civil disturbances following the incidents in Bensonhurst and Howard Beach, New York, as well as the violence and destruction that followed court decisions in the Rodney King case illustrate the courts' fear that bias crimes could exacerbate existing racial tensions to the point of community violence. The Oregon Court of Appeals refers to this elusive attribute of bias crime as the power to "escalate from individual conflicts to mass disturbances" (Harvard Law Review, 1996). Although the Supreme Court and other courts across the country have noted the difference between the two types of crime, research is scant as to precisely how this type of crime affects the victims.

\section{PRIOR LITERATURE ON HATE CRIME VICTIMIZATIONS}

Research regarding the impact of bias crimes is limited. Although there has been significant research about the general victimization process, very little examines the complex relationship between bias motivation, incidence of crime, and victimization consequences. Moreover, of the few that do examine the extent of psychological and emotional injury suffered by bias crime victims, most fail to provide comparative data for victims of similar non-bias-motivated offenses.

Whereas numerous studies have been conducted to describe the psychosocial consequences of particular types of victimization (e.g., Freedy, Resnick, Kilpatrick, Dansky, \& Tidwell, 1994; Frieze, Greenberg, \& Hymer, 1987; Kilpatrick, Saunders, Veronen, Best, \& Von, 1987; Sales, Baum, \& Shore, 1984), only a handful compare symptoms across crime types (Davis \& Brickman, 1996; Lurigio, 1987; Resick, 1987; Riggs \& Foa, 1995; Wirtz \& Harrell, 1987), and even fewer are specific to bias crime victimization (Barnes \& Ephross, 1994; Ehrlich, Larcom, \& Purvis, 1994; Ephross, Barnes, Ehrlich, Sandnes, \& Weiss, 1986; Herek, Cogan, \& Gillis, 1999; Herek, Gillis, Cogan and Glunt, 1997). In part due to methodological issues, the results of these studies on bias crime victimization are somewhat inconsistent in their conclusions.

According to Barnes and Ephross (1994), the most prevalent emotional reaction of the 59 bias victim respondents was anger toward the offender, followed by fear. When comparing the victims of bias and nonbias assault, their data indicated that 
a major difference in the emotional response of hate violence victims appears to be the absence of lowered self-esteem. The ability of some hate violence victims to maintain their self-esteem may be associated with their attribution of responsibility for the attacks to the prejudice and racism of the perpetrators. (p. 250)

Although these data are notable, the purposive sampling technique and small sample of respondents raise questions about the generalizability of the findings.

Conversely, Ehrlich et al. (1994) in their national telephone victimization survey (2,078 respondents) revealed marked differences in the traumatic effects of hate violence. They indicated that among four subgroups (i.e., nonvictims, group defamation victims, personal crime victims, and bias crime victims), bias crime victims demonstrated the greatest average number of symptoms and behavior variations on a scale of 19 psychophysiological symptoms of posttraumatic stress and 12 social and behavioral changes. The authors reported a clear overall pattern of pervasive consequences in the lives of victims of bias crime and concluded that "ethnoviolence [bias crime] victims suffer greater trauma than do victims of ... violence which is committed for other reasons" (p. 27). Specifically, ethnoviolence victims reported experiencing 5.98 negative psychophysiological aftereffects, whereas personal victims had 4.77, and group defamation victims reported 4.02. According to this study, victims of ethnoviolence were also significantly more nervous, lost more friends, had more trouble sleeping or concentrating, had more interpersonal difficulties, and felt angrier than those victims of personal crimes.

In a related study to Ehrlich et al. (1994) on the effects of ethnoviolence in the workplace, once again the victims of ethnoviolence reported the greatest number (5.6) of psychophysiological symptoms on the same 19-point list. Whereas personal victims reported only 3.5 , victims of prejudicial insults or jokes reported 5.0 (Barnes \& Ephross, 1994). The limitation to this study, however, is the broad definition of bias incidents asked of workers during the interview. Participants were asked, "In the past 3 years, have you ever been mistreated at this company?" They were then asked to determine whether they felt this was due to some prejudice.

More recently, Herek et al. (1999) explored the psychological sequelae of gay, lesbian, and bisexual bias crime victims. Recruiting from gay/lesbian community events (i.e., Gay Pride celebration, etc.), gay bars, or community organizations, the research team recruited more than 2,000 participants to fill out a self-administered questionnaire. This study marks the most expansive empirical effort to include bias crime victims, and although the sample is somewhat skewed toward gay/lesbians who are public about their sexuality (i.e., are able to attend gay/lesbian/bisexual functions, community organizations, etc.), this research is notable for its sample size.

The data indicate that those respondents who reported experiencing a bias crime (compared with victims of nonbias crimes) within the past 5 years consistently had more intense feelings of adverse psychological sequelae. Statistically 
significant relationships were found for depressive symptoms, traumatic stress, and anger. One of the methodological limitations in this study, however, is how the research team coded bias and nonbias events; events were classified as bias or nonbias by asking respondents whether they felt they were victimized because of their sexual orientation. It is possible that this subjective interpretation might be related to other characteristics of the victim, such as the victim's political orientation toward gay, lesbian, and bisexual issues, and thus may also influence the impact of the crime. Despite this limitation, these data indicate additional support for the belief that bias crime victims endure more intense effects of victimization on several dimensions.

With the exception of these few studies, little is known about the differences between bias and nonbias victimization. These studies represent the first attempt by researchers to quantify the psychological and behavioral impact of bias crime victimization. The current study attempts to provide further information on some of these issues.

\section{RESEARCH DESIGN/METHOD}

The present study takes a comparative look into the experience of bias and nonbias victims. One of the primary goals of the design is to be able to make comparisons between similar bias and nonbias crime victims in an effort to understand if bias crime victims experience differential impacts. To achieve this goal, this study surveys a comparable group of violent bias and nonbias assault victims identified from law enforcement and advocacy agency legal records.

When designing this study, we estimated that the most powerful data about the victimization experience would be from the victims themselves. To this end, we created a mail survey instrument to be sent to all victims of bias-motivated aggravated assault in the city of Boston ${ }^{1}$ within the years of 1992 to 1997 and a random sample of nonbias assault victims. The notable exceptions to this list were domestic assaults and child abuse. Because both of these categories touch on specific phenomena, the team felt that their inclusion would be inappropriate. Therefore, all incidents coded as a domestic assault or child abuse (by the responding officers at the Boston Police Department) have been excluded from both the experimental and control groups in this study.

Because there were considerably more nonbias assaults during the same time frame, the research team used a 10\% random sample of this group. Once the lists were constructed, each name was given a numeric identifier, allowing the research team to track which victims had or had not responded.

In addition to the databases accessed through the Boston Police, the research project staff reviewed records from a prominent Boston gay/lesbian community advocacy center. From these records, researchers contacted by mail victims of violent bias crime assaults from the years 1992 to 1997 who had not been previously identified through law enforcement records. 
Several points of contact were made with victims to maximize response rates. First, the research team and advisory board all agreed that victims should be given advanced notification of the study so as not to shock a victim with a highly sensitive survey about his or her victimization. Therefore, victims were sent a preliminary letter, notifying them that they were selected to participate in a study on the effects of victimization. To be sensitive to all victims, victims were given the option to elect not to participate in the study by contacting a representative to remove their name from the list for future mailings. Several victims called to request information, but very few people called to say they did not wish to participate.

Next, the self-administered questionnaire was compiled with advice from an advisory board with several distinguished bias crime scholars. ${ }^{2}$ The final survey instrument employed the Horowitz Impact of Events Scale (Horowitz, Walker, \& Alvarez, 1979) to gain insight into the psychological sequelae involved in the victimization process. In addition to being used in several settings to enhance reliability of the instrument, this instrument has also been employed in prior research with bias crime victims (Ehrlich et al., 1994). Also included in the survey packet was a copy of the police incident report ${ }^{3}$ so that victims could correctly remember the particular incident that we were requesting information about; victims were also encouraged to include any additional information and/ or correct anything on the original police report. For those victims who had experienced more than one victimization, it clarified which incident that our survey was targeting. In addition, to reduce the trauma associated with reliving the incident, a list of social service and advocacy agencies was provided with the questionnaire so that those victims who felt they needed additional help could access support services. Finally, respondents who had difficulty writing were given the option for a member of the research team to assist them either by phone or in person.

Unfortunately, nearly $50 \%$ of the initial mailings were returned with address unknown; "moved, left no forwarding address"; and so forth. In an attempt to find these victims, the research team used the computer-tracking program Autotrack and was able to locate a little more than half of the unknown addresses. Still, even after locating many of the victims' addresses, the response rate remained low. In an effort to increase the response rate, the research team decided to offer victims compensation $(\$ 15)$ for their time to complete the survey, a method that has been employed in several previous victim studies (Davis \& Brickman, 1996; Herek et al., 1997; Rothbaum, Foa, Riggs, Murdock, \& Walsh, 1992). Despite the monetary incentive, the personalization of the second survey mailing, and the repetition of sending another reminder/mailing, the overall response rate did not significantly improve. Unfortunately, the response still remained quite low at approximately $23 \%$ for the bias assault victims and $11 \%$ for the nonbias victims. It must be noted that with such a low response rate, it is likely that our sample is nonrepresentative in many ways. We do expect, 
however, that similar response problems will affect both our bias and nonbias assault victim samples.

The final draft of the victim survey contained sections about the incident, the psychological and behavioral aftermath, family and community responses to the event, perceptions of police and prosecutors' roles and efficacy, and demographic information. The survey also attempted to address the impact of the victimization by relating the incident to other major life events (i.e., major illness, divorce, death of family member, etc.). Several scales of coping strategies were devised, drawing from a comprehensive review of previous crime victim research literature. This article will focus on the psychological and behavioral impact of violent bias crime victimization.

\section{SAMPLE CHARACTERISTICS}

A review of the characteristics of the two samples reveals surprising similarities considering the difficulties encountered in obtaining survey responses (see Table 1). About $40 \%$ of each sample of victims are female (37.8\% vs. $40 \%$ ), and the racial and ethnic makeups are similar for the two respondent samples. When we consider the age breakdown of the samples, the bias crime sample is slightly younger, with nonbias victims about twice as likely to be older than 45 years. In addition, the samples are very similar in terms of income and education. Finally, as expected, the bias crime sample is more likely to include victims who identify themselves as gay, lesbian, and bisexual.

\section{CHARACTERISTICS OF INCIDENT}

In general, there were few differences between the location of the incident and whether the incident was or was not bias related. It does appear, however, that slightly more of the bias sample were victimized in the area of their home (37\% vs. $30 \%$ ), and nonbias assaults were more likely to occur at work (14\% vs. $7 \%$ ).

Our data are consistent with 1997 UCR Hate Crime Reporting data regarding location of the incident. Approximately one third of both samples were victimized in the area of their home. The UCR location category "street/transportation" is similar to our category of "enroute to/from somewhere" from our survey. Both measures are imprecise in illuminating whether the particular spot was just outside a victim's residence or many miles away. For this reason, we speculate that some percentage of those who are victimized "on the street" or traveling are within a very short distance from their homes due to the fact that an individual's home is usually the pivotal point (going to and coming from) for most travel. Such distance is relevant in interpreting subsequent psychological sequelae for victims.

Prior research has looked at the impact of location on victimization and subsequent post-traumatic stress disorder. Schepple and Bart (1983) found in their 
TABLE 1: Comparative Statistics Between the Samples of Bias and Nonbias Assault Victim Respondents

\begin{tabular}{|c|c|c|}
\hline $\begin{array}{l}\text { Demographic } \\
\text { Variables Subcategory }\end{array}$ & $\begin{array}{c}\text { Bias Victim } \\
\text { Respondents }(\mathrm{n}=91)\end{array}$ & $\begin{array}{c}\text { Nonbias Victim } \\
\text { Respondents }(\mathrm{n}=45)\end{array}$ \\
\hline \multicolumn{3}{|l|}{ Gender } \\
\hline Male & 62.2 & 60.0 \\
\hline Female & 37.8 & 40.0 \\
\hline \multicolumn{3}{|l|}{ Age (years) } \\
\hline Younger than 18 & 12.5 & 11.1 \\
\hline $18-24$ & 11.4 & 13.3 \\
\hline $25-44$ & 62.5 & 48.9 \\
\hline 45 and older & 13.6 & 26.7 \\
\hline \multicolumn{3}{|l|}{ Race and Latino ethnicity } \\
\hline White & 62.2 & 52.4 \\
\hline Black & 23.3 & 33.3 \\
\hline Asian & 6.7 & 7.1 \\
\hline Other & 2.2 & 2.4 \\
\hline Latino ethnicity & 5.6 & 4.8 \\
\hline \multicolumn{3}{|l|}{ Household income (\$) } \\
\hline$<20,000$ & 42.7 & 38.9 \\
\hline $20,000-39,999$ & 28.0 & 22.2 \\
\hline $40,000-59,999$ & 8.5 & 13.9 \\
\hline $60,000-79,999$ & 12.2 & 11.1 \\
\hline $80,000-99,999$ & 3.7 & 8.3 \\
\hline 100,000 or more & 4.9 & 5.6 \\
\hline \multicolumn{3}{|l|}{ Education } \\
\hline$<$ high school/NA & 26.1 & 17.8 \\
\hline High school/some college & 35.2 & 46.7 \\
\hline College graduate & 22.7 & 20.0 \\
\hline Postgraduate & 15.9 & 15.6 \\
\hline \multicolumn{3}{|l|}{ Sexual orientation } \\
\hline Heterosexual & 68.8 & 94.4 \\
\hline Bisexual & 2.5 & 0.0 \\
\hline Lesbian & 6.3 & 2.8 \\
\hline Gay male & 22.5 & 2.8 \\
\hline Transgender & 0.0 & 0.0 \\
\hline
\end{tabular}

study of sexual assault victims that women who believed they were in a safe place during the attack were more likely to experience more severe trauma. The authors speculated that victims who are attacked in a perceived safe place are not able to employ "victim blaming" techniques and thus have no buffer from the severe psychological impact of victimization. Victim blaming allows the victim to feel that if he or she had augmented his or her behavior, he or she could have prevented the incident. The important corollary to this is that victims can use this strategy to reduce their fears about future victimization, asserting that if they change their behavior, they can be safe. However, because it is difficult to determine whether our measure of "passing through the area" indicates near the 
victim's home or not, we are unable to understand the context of location for a substantial percentage of victims. Although the differences between the bias and nonbias group are not significant, it is notable that a larger percentage of bias victims are victimized near their homes, thus making the victims more vulnerable to the postincident effects mentioned above.

The one measure that more closely approximates the context of whether the place of victimization is considered safe by the victim is the question about frequency. We asked victims whether they had been to this location (before the incident occurred) "never," "a few times," "quite often," or "almost every day." When we collapse these categories into never/a few times and quite often/almost every day, we find that bias victims are more likely to be victimized in locations that are familiar to them. More than three quarters of the bias group tended to frequent the location where the incident occurred often, compared to only two thirds of the nonbias group. After the incident, only $28 \%$ of the bias victims and $34 \%$ of the nonbias victims returned almost every day. Although these differences are not statistically significant, they are instructive in understanding the context of the crime.

Next, bias crime victims were also more likely to be attacked by a group of attackers than our comparison sample of nonbias victims (49\% vs. $35 \%)$. The bias victims had a mean of 2.04 attackers, compared to the nonbias group, who had a mean of 1.84 attackers. It is interesting to note that in this sample, about one quarter of each group were attacked by a group of four or more offenders (23\% vs. $25 \%)$.

\section{RELATIONSHIP TO OFFENDER}

Several studies have explored the relationship between victim and offender in cases of sexual assault (Katz, 1991; Koss \& Cox, 1984; Ullman \& Seigel, 1993). Although these studies focus on different aspects of the healing process, Ullman and Seigel (1993) found that fear and anxiety were more common for women sexually assaulted by strangers. Katz (1991), however, found that women victimized by strangers are more likely to retain a positive self-image than women who are raped by nonstrangers.

In our sample, bias crime victims were significantly less likely to have a prior relationship with the offender than were nonbias victims $(83.5 \%$ to $68.2 \%$,). One quarter of the nonbias group reported that they knew their attacker for at least 1 year, compared to less than $7 \%$ of the bias crime victims.

The survey also asked victims to relay how they describe the nature of the incident. They were asked if the assault was "an unprovoked attack against me," "an ongoing dispute," "a minor disagreement that got out of hand," a case of "mistaken identity," or "a poor response to a situation by the offender." This is important because several critics of bias crime legislation have suggested that many bias crimes are simply the result of disputes between individuals of different groups. The data here contradict this assertion; nearly all the bias crime 
assaults were committed by strangers (84\%), and most victims reported that the assault was the result of an unprovoked attack (76\%). Only $8 \%$ of the bias crime victims reported that the attack was a result of an ongoing dispute. When comparing the two samples, bias crime victims were more likely to have been attacked by strangers and more likely to see the attack as unprovoked (76\% vs. $53 \%$ ). This supports the prior contention in the literature that bias crime victims are chosen because of their membership in a group and not because of any prior actions they may have taken. As opposed to many other assault victims, bias crime victims are interchangeable; as far as the offender is concerned, any member of the group could be selected as a target.

Whereas these questions are helpful in understanding the qualitative context of the precipitants of the assault, the next set of questions asks the victims to directly attribute levels of responsibility to the victim, offender, or other individual. Specifically, we asked victims to assess responsibility for the incident on a scale of 0 to 10 , with 0 indicating that the victim had no responsibility for the attack and 10 indicating that the victim assumed full responsibility. Once again, the responses are consistent with the earlier conclusions. Bias crime victims are more likely to report that they had no responsibility for the incident than nonbias crime victims ( $76 \%$ vs. $58 \%$ ). This again fits with the prior descriptions of bias crimes that most bias crime victims feel that they did nothing to provoke or initiate the attack.

Many nonbias victims reinforced the lack of responsibility for the assault in their qualitative remarks when asked how to reduce/prevent these types of crimes in the future. Whereas bias crime victims often pointed to a community responsibility, nonbias victims were more likely to respond that the reduction/ prevention of assault was within their own control, inferring they may have precipitated the crime by their own overt actions. Many responses from nonbias victims involved changing their own behaviors. The following responses were typical for the nonbias group when asked what they might do to prevent such crimes in the future.

- "Walk away from the incident."

- "Be polite."

- "Look away, but it is hard not to ..."

- "Not to settle quarrels physically."

On the contrary, bias crime victims expressed feelings of frustration when asked how to prevent or reduce such crimes in the future. They generally did not indicate that their actions had done anything to provoke or exacerbate a situation, confirming the responses from earlier questions about the nature of the assault. Because most bias crime victims did not believe they could do anything to prevent future victimization, they felt frustrated. The following response captures many of the bias crime respondents' feelings about preventing victimization: 
"Not to be in the wrong place at the wrong time. In other words, it's impossible." Such remarks indicate that bias crime victims feel largely powerless to protect themselves in the future.

Collectively, the responses to questions about the level of responsibility, precipitating incident events, and prior relationship paint a picture of bias crime assaults that is different in many ways from that of nonbias assaults. These events are less likely to involve victims and offenders who are friends or acquaintances and to be precipitated by any overt actions by the victim, and the onus of responsibility appears to lie much more fully with the offender.

\section{MEDICAL TREATMENT}

We asked victims whether they sought medical assistance as a result of the incident. Because our sample included only aggravated assault victims, we expected that some physical harm would be involved in most of these incidents. There was little difference in the number of victims from each sample who required overnight hospital treatment (15\% vs. $16 \%$ ), but bias crime victims reported that they went to the hospital emergency room for treatment less often ( $29 \%$ vs. $43 \%$ ). However, less than $60 \%$ of the sample answered this question. In retrospect, our measure may have been imprecise, and the low response rate is a reaction to ill-fitting response categories. This conclusion may indicate that nonbias victims in our sample were more likely to suffer serious injury, or it may indicate that bias crime victims are reluctant to go to the emergency room after being attacked. Whatever the reason, definitive conclusions regarding the extent of medical treatment for comparable victims are not supported from these data. Further analysis is necessary to determine if bias crime victims are more likely to receive more serious physical injury in their attacks.

\section{REPORTING PRACTICE}

When victims were asked if they had spoken to anyone prior to reporting the crime to the police, bias crime victims were more likely to report that they had sought out someone to discuss the incident with prior to reporting the assault to the police ( $40 \%$ vs. $29 \%$ ). In most cases, the victim went to a family member or a friend before he or she reported the crime to the police. The fact that nearly half of the bias-motivated victims report discussing the attack with someone before formally reporting to the police may have important implications for improving the reporting of bias crimes nationally. It may be necessary to broaden the previctimization outreach efforts to include families of victims as well as the victims themselves. In addition, it may be necessary to increase the availability of victim support programs, where victims can go to obtain support and assistance before they become formally involved in the criminal justice system. 


\section{VICTIM REACTIONS}

\section{BEHAVIORAL REACTIONS}

Twelve separate indicators measured postvictimization behavioral changes, each with a dichotomous variable (yes or no). Surprisingly, there were no significant differences between the bias and nonbias groups. Both groups of assault victims appear to take the same steps postvictimization: The overwhelming majority of victims in both groups (77.4\% for bias, $77.8 \%$ for nonbias victims) stated that they pay more attention to where they walk now. More than a third of both samples stated that they try to be less visible since the incident $(37.8 \%$ for bias, $38.6 \%$ for nonbias victims). Twenty-two percent of both samples responded that they had become more active in the community because of the victimization. Overall, however, the similarities in behavior modifications between the groups are striking. The same can not be said, however, for the psychological sequelae of the bias and nonbias victims. We will return to the findings of the behavioral responses during the discussion section of this report.

\section{PSYCHOLOGICAL REACTIONS}

Using Horowitz's Impact of Event Scale (Horowitz et al., 1979) to understand some of the psychological sequelae, we asked victims from both groups the same questions about postevent distress. Horowitz has suggested that the psychological themes in his scale can be grouped into two major components: intrusiveness and avoidance. Our scale incorporated one major change from the original scale; although we used basically the same symptoms, we measured the response differently. Originally, Horowitz employed a "not at all, rarely, sometimes, often" response framework for each of the scale items, within a time frame of "within the last seven days." On the suggestion of our advisory group, we decided to account for differences between the groups while incorporating a time dimension, thus further refining the sometimes category of the original scale. In addition, because our sample included victims who had been victimized spanning 1 month to 6 years prior to the administration of the survey, asking whether the respondent encountered the adverse stimuli or reaction always, sometimes, rarely, or not at all as was done in the original Horowitz instrument would conceal the time- sensitive nature of the impact. Respondents were asked whether they experienced the particular emotion or coping technique "not at all," "for a few days," "for a few weeks," "for a few months," or "for a few years." In short, our measures represent an attempt to incorporate both a measure of intensity and duration.

Although there were only six items from Horowitz's Psychological Scale where significant differences exist between the bias and nonbias victim groups, every psychological impact measure from this scale had a higher mean value from the bias group than from the nonbias group. This means bias crime victims 
experienced the adverse psychological sequelae more often than the nonbias control group on every item we measured. Although the levels of significance vary, the relationship does not vary; bias crime victims clearly experienced more negative impacts and experienced these impacts for longer periods of time than the nonbias victim group.

The psychological impact of crime on the victim is measured in our study by 19 separate scale items. A $t$ test was performed between the bias-motivated and non-bias-motivated assault victim groups on each reaction category. A (moderate) statistically significant difference was detected between the two groups within 5 of the 19 categories $(p<.05)$. The largest categorical difference was in "feeling angry" with a $t$ score of 2.625 and a mean difference of .54 on a 5-point scale (i.e., not at all, days, weeks, months, and years).

All of the five variables that are statistically significant at the .05 level are related to Horowitz's intrusiveness theme. Bias crime victims cite that they are more nervous, more depressed, have more trouble concentrating, think about the incident when they do not mean to, and feel like not wanting to live any longer more often than nonbias victims. Collectively, we see that the bias group has more difficulty coping with the victimization and that they appear to have additional problems with their recovery process due to increased fear and more frequent intrusive thoughts.

One could, however, persuasively argue that due to imprecisely characterizing the mean as an instrument of comparison in the $t$ test, we may have somehow blurred the test of significance. To address this, the research team split these variables in several different ways. First, we collapsed the psychological variables into two categories: either the presence of the symptom (coded as 1) or the absence of it (coded as 0). Collapsing these categories yields very similar results. Once again, feelings of depression, nervousness, difficulty concentrating at work, and feeling ashamed/losing confidence are significant below the .05 level. These results indicate that there is a relationship between the element of bias in assault that is strongly related to whether the victim experiences these adverse psychological sequelae at all.

At this point in the analysis, the research team wished to test the bivariate relationships further within the psychological sequelae. Specifically, one could argue that the difference between having symptoms for a few days and not having them at all is not very remarkable. For this reason, we created a separate dichotomous variable that collapsed categories into not at all/for a few days (coded as 0) and a few weeks, months, years. This division makes the implicit objective assumption that most victims of violence will sustain some impact; however, when the impact duration creeps into weeks or months, there is something notable about it.

The results from this analysis are congruent with earlier tests of significance. Four variables - more nervous than usual, thought about when I didn't mean to, didn't feel like living any longer, and had trouble concentrating at work-all indicated a Pearson value below the .05 level of significance. Again, we see that 
the level of intrusiveness for the bias crime victim is greater than for the nonbias victims. In this version of the analysis, only more depressed falls from being significantly different between the two groups.

The research team also designed the 19-item Impact of Event Scale into a collective score. We did this by taking the mean of each respondent's 19 answers, excluding surveys where more than 5 answers on the scale were missing. We ran these collective scale scores and found that once again, the differences between the two groups are significant (Pearson's value .041), with the bias group more likely to have a mean above 1.5 (67\% to $48.9 \%)$. There is also a significant correlation between the mean score for the Psychological Scale and whether the victim is from the bias or nonbias group (.03). Once again, this indicates the strength of the relationship between psychological sequelae and the presence of bias in the incident. By nearly every bivariate measure, the bias victims are affected more intensely, with more intrusive psychological sequelae.

\section{FEELINGS OF SAFETY}

When asked how safe the victims feel after the crime, bias crime victims are significantly less likely to feel safe. Almost one half of the nonbias victims reported feeling less safe after the incident (46\%), but a significantly higher number of bias crime victims reported feeling unsafe after their attack (59\%). This increased fear is interesting because the nonbias attacks were more likely to have involved reported injury. One possible reason for this increased fear may be that bias crime victims are more likely to be concerned that a similar crime may happen in the future, especially because they have experienced previous attacks more frequently. Fully $52 \%$ of the bias crime sample reported that they were very concerned about becoming a victim of a similar crime in the future; this compares to $37 \%$ of the nonbias crime sample who reported that they were very concerned about future victimization. In addition, after the incident, bias crime victims were more likely to report that they felt unsafe alone in their neighborhood at night ( $42 \%$ vs. $32 \%)$ and that they felt unsafe returning to the area of the incident (52\% vs. $44 \%$ ). Taken together, these findings indicate that bias crime assault victims are more likely to experience increased fear and reduced feelings of safety after the crime than nonbias crime assault victims.

\section{OTHER VICTIMIZATION CONSEQUENCES}

We asked both samples if they had experienced other negative life events since the assault. In most areas, the bias crime sample reported that they had endured more negative experiences since the assault. For example, bias crime victims were more likely to report that they had lost employment (50\% vs. 34\%) since the assault. In addition, bias crime victims reported that they had had significant health problems after the assault ( $48 \%$ vs. $32 \%$ ). Conversely, the nonbias group was more likely to experience a divorce or separation (15\% vs. $7 \%)$. Although it is 
impossible to determine if these changes are related to the assault that preceded them, it is true that many of the bias crime victims in this sample experienced more traumatic events in their lives following the original assault.

In addition, we asked each sample a summary question: "Overall, how difficult was it for you to overcome the effects of this incident?" Here again, the bias crime sample was almost three times more likely to report that overcoming this incident had been very difficult ( $36 \%$ vs. $13 \%)$.

\section{CONCLUSION}

Our data have several limitations. First, the limited sample size reinforces the need for replication. Second, the nonrepresentative sample raises questions about generalizability. However, the difficulties we encountered in getting victims to respond, and our efforts to improve responses, can inform future research projects. Both bias and nonbias victim groups were hard to locate, and when correct addresses were found, they were hesitant to respond through the mail. This population may need more intensive efforts, such as interviews instead of self-administered questionnaires, as a methodology to encourage participation in sharing their victimization experiences.

Despite our methodological difficulties, our data confirm several previously posited hypotheses. First, compared to non-bias-motivated assaults, the incidence of bias crime tends to be perpetrated by multiple offenders upon strangers, and the victims of bias crimes are more likely to be victims selected only because they belong to a particular group. Bias crimes are more likely to occur in locations familiar to the victim, and bias crime victims are much more likely to experience increased fear after the incident. In addition, victims of bias assault are more likely to feel the effects of victimization more intensely and for a longer period of time. Whether this is a result of the inability to employ traditional coping mechanisms or due to some other phenomena, bias crime victims suffer more intense intrusive psychological sequelae than do nonbias assault victims.

Although the behavioral responses may initially seem surprising, we believe these also confirm earlier hypotheses. First, the element of victim interchangeability injects a unique dynamic into the victimization process. Victims are aware that their overt actions did nothing to precipitate their victimization; being the "wrong person," at the wrong time and place, qualifies the bias victim. Therefore, if the impetus for victimization is something that is outside of the bias victim's control before the incident, it is reasonable that there would be little that the victim would do differently subsequent to the incident. Qualitative responses from open-ended questions on the survey confirmed that victims were aware of their distinct vulnerability, whereas nonbias victims indicated that their behavior may have encouraged the offender or exacerbated a tense situation among acquaintances. Psychological sequelae, however, are less easily controlled by the victim. The level of intrusive thoughts created by the incident and 
the feelings of helplessness associated with bias-motivated victimization all point to a unique victimization process for bias victims.

This research supports the conclusion that bias crimes affect their victims differently from nonbias crimes. Victims of bias crimes are more fearful after the incident and are more likely to experience a series of intrusive thoughts. This is true even if we control on the type of crime, in this case, assaults. Although it is beyond the scope of our study to definitively conclude whether various hate crime legislation is justified, it is clear that bias victims have distinct needs. These conclusions support the claim that bias crimes do in fact affect their victims differently and that consequently law enforcement and social service agencies should be cognizant of these differences in assisting bias crime victims.

Lastly, this project does not begin to address the impact that bias crimes have on the secondary victims, the community. Because bias crimes have the unique impact of reaching far beyond the primary victim, due to the dimension of victim interchangeability, every member of the minority group who is aware of the crime is affected by a solitary crime against one individual minority member. Unfortunately, this is well beyond the scope of the current study. With these considerations in mind, we hope that the research community will both attempt to replicate this research with additional bias victim samples, as well as tap into the important dimension of secondary victimization.

\section{NOTES}

1. The city of Boston was selected due to its comprehensive strategies for investigating bias crimes through the Community Disorders Unit, formed in 1979 in response to heightened racial tensions within the city. Because of this, the research team had access to an extensive database of bias crime offenses.

2. The advisory board was composed of representatives from the U.S. Attorneys Office, the Anti-Defamation League, the district attorney's office, the victim/witness office, the NAACP, gay/ lesbian community centers, the Boston Police Community Disorders Unit, the Massachusetts Office of Corrections, and members of the academic community who specialize in both international and domestic bias crime studies.

3. All offender information was redacted according to the Boston Police Department's legal guidelines.

\section{REFERENCES}

Barnes, A., \& Ephross, P. H. (1994, May). The impact of hate violence on victims: Emotional and behavioral responses to attacks. Social Work, 39(3), 247-251.

Davis, R., \& Brickman, E. (1996). Supportive and unsupportive aspects of the behavior of others toward victims of sexual and non-sexual assault. Journal of Interpersonal Violence, 11(2), 250-262.

Ehrlich, H. J., Larcom, B.E.K., \& Purvis, R. D. (1994, May). The traumatic effects of ethnoviolence. Towson, MD: Prejudice Institute, Center for the Applied Study of Ethnoviolence. 
Ephross, P. H., Barnes, A., Ehrlich, H. J., Sandnes, K. R., \& Weiss, J. C. (1986, October). The ethnoviolence project: Pilot study. Baltimore: National Institute Against Prejudice and Violence.

Freedy, J., Resnick, H., Kilpatrick, D., Dansky, B., \& Tidwell, R. (1994). The psychological adjustment of recent crime victims in the criminal justice system. Journal of Interpersonal Violence, 9(4), 450-468.

Frieze, I. H., Greenberg, M. S., \& Hymer, S. (1987). Describing the crime victim: Psychological reactions to victimization. Professional Psychology: Research and Practice, 18(4), 299-315.

Harvard Law Review. (1996). Penalty enhancement does not punish free speech or thoughts. In B. Leone \& P. A. Winters (Eds.), Hate crimes (pp. 121-129). San Diego, CA: Greenhaven Press.

Herek, G., Gillis, J. R., Cogan, J. C., \& Glunt, E. K. (1997, April). Hate crime victimization among lesbian, gay, and bisexual adults: Prevalence, psychological correlates, and methodological issues. Journal of Interpersonal Violence, 12(2), 195-215.

Herek, G. M., Cogan, J. C., \& Gillis, J. R. (1999). Psychological sequelae of hate crime victimization among lesbian, gay and bisexual adults. Journal of Consulting and Clinical Psychology, 67(6), 945-951.

Horowitz, M., Walker, N., \& Alvarez, W. (1979, May). Impact of Events Scale: A measure of subjective stress. Psychosomatic Medicine, 41(3), 209-218.

Jacobs, J., \& Potter, K. (1998). Hate crime: Criminal law and identity politics. New York: Oxford Press.

Katz, B. (1991). The psychological impact of stranger versus nonstranger rape on victims' recovery. In A. Parrot \& L. Bechhofer (Eds.), Acquaintance rape: The hidden crime (pp. 251-269). New York: John Wiley.

Kilpatrick, D. G., Saunders, B. E., Veronen, L. J., Best, C., \& Von, J. M. (1987). Criminal victimization: Lifetime prevalence, reporting to police, and psychological impact. Crime \& Delinquency, 33(4), 479-489.

Koss, D., \& Cox, S. (1984). Stranger and acquaintance rape: Are there differences in the victim's experience? Psychology of Women Quarterly, 12, 1-24.

Levin, J., \& McDevitt, J. (1993). Hate crimes: The rising tide of bigotry and bloodshed. New York: Plenum.

Lurigio, A. J. (1987). Are all victims alike? The adverse, generalized, and differential impact of crime. Crime and Delinquency, 33(4), 452-467.

Resick, P. (1987). Psychological effects of victimization: Implications for the criminal justice system. Crime and Delinquency, 33(4), 468-478.

Riggs, R, \& Foa, E. (1995). A prospective examination of symptoms of post-traumatic stress disorder in victims of nonsexual assault. Journal of Interpersonal Violence, 10(2), 201.

Rothbaum, B., Foa, E., Riggs, D., Murdock, T., \& Walsh, W. (1992). A prospective examination of post-traumatic stress disorder in rape victims. Journal of Traumatic Stress, 5(3), 455-475.

Sales, E., Baum, M., \& Shore, B. (1984). Victim readjustment following assault. Journal of Social Issues, 40(1), 117-136.

Schepple, K. L., \& Bart, P. B. (1983). Through women's eyes: Defining danger in the wake of sexual assault. Journal of Social Issues, 39(2), 63-81.

Ullman, S. E., \& Seigel, J. M. (1993). Victim-offender relationship and sexual assault. Violence and Victims, 8(2), 121-133.

Wirtz, P., \& Harrell, A. (1987). Victim and crime characteristics, coping responses, and short and long- term recovery from victimization. Journal of Consulting and Clinical Psychology, 55(6), 866-871.

Wisconsin v. Mitchell, 508 U.S. 476 (1993). 


\title{
Extremism and the Constitution
}

\author{
How America's Legal Evolution Affects \\ the Response to Extremism
}

\author{
BRIAN LEVIN \\ Center for the Study of Hate and Extremism, \\ California State University, San Bernardino
}

\begin{abstract}
The current protections that American law provides for extremist speech and associations are relatively new developments. These legal protections, along with technological innovations, enable modern American hatemongers to promote their agenda efficiently and with minimal governmental interference - up to a point. The courts have balanced the right of free expression and association on one hand with the right of society to protect its citizens from violence and disruption on the other.
\end{abstract}

Everyone in this great nation has the right to think and believe, [and] speak whatever they want. We are not prosecuting McVeigh because we don't like his beliefs or even his speech, we're prosecuting him because his hatred boiled into violence and his violence took the lives of innocent men, women, and children. And the reason we'll introduce evidence of his thoughts is because they reveal his premeditation and his intent, and intent is an element of the crime we must prove.

$$
\begin{aligned}
& \text {-Opening statement of Joseph Hartzler, } \\
& \text { prosecutor (United States v. McVeigh, 1997) }
\end{aligned}
$$

There is no shortage of dangerous, hateful invective in modern American discourse. These dissident voices can be heard at Klan rallies, in hate rock music, on the Internet, in broadcast statements of foreign terrorists, and in books that unabashedly promote violence and bigotry. This article will focus on a variety of expressive and associational criminal law issues relating to extremism against Americans. Many of these legal explanations will be prefaced by the words of notorious hatemongers, terrorists, and others, to add a relevant present-day context to the analysis. The legal issues subject to examination in this article include protected speech and various types of associations, hate crime laws, and regulating expression on the Internet.

The current state of First Amendment protections in the United States offers a broad range of protections for even the most offensive kinds of nonviolent activities and speech undertaken by extremists. It is not a rare refrain from people of

AMERICAN BEHAVIORAL SCIENTIST, Vol. 45 No. 4, December 2001 714-756

(C) 2001 Sage Publications 
goodwill to "just do something" about the myriad violent, hateful, false, and offensive messages communicated by extremists. Unfortunately, during the course of American history, punishable "extremism" has often been in the eye of the beholder. Today's extremists are the beneficiaries of an evolved interpretation of the First Amendment that was not available to controversial figures of earlier eras. American history is replete with politically influenced governmental abuses designed to interfere with the exercise of expressive or associational rights of controversial dissenters. These incidents include governmental targeting of

- government critics under the Alien and Sedition Acts in the late 1790s,

- African Americans pursuant to Jim Crow laws after the Civil War,

- peaceful antiwar and prolabor activists after America's involvement in World War I,

- the Ku Klux Klan in the 1920s and American Nazis and Bund members in the 1930s,

- Jehovah's Witnesses during the 1930s and 1940s,

- leftists and alleged communists in the 1950 s,

- civil rights activists including Martin Luther King and Malcolm X in the 1960s, and

- antiwar activists protesting the Vietnam War in the 1960s and 1970s.

When we discuss free expression in the First Amendment context, we are really talking about several closely related protections. Those are the explicitly referenced freedoms of speech, press, and assembly and the implicit rights to association and thought.

There are at least three underlying justifications for protecting free expression in a democratic society. The first is that the public's exposure to a wide range of ideas serves an important truth-seeking function. The theory being that the veracity of a particular idea is best established when it competes in a marketplace of ideas. Second, expressive rights are so sacred to individual autonomy, and so subject to abuse by government officials, that severe restrictions on governmental interference are warranted. Third, the uniform protection of all types of expression prevents the majority or the powerful from conspiring with the government for silencing unpopular speakers of ideas. As legal scholar David Cole (1992) explained, "If the history of political struggles teaches us anything, it is that the majority will often seek to regulate the speech of the politically powerless."

\section{THE GENESIS OF THE FIRST AMENDMENT}

The First Amendment was ratified in 1791 as part of the original Bill of Rights to the Constitution. Thomas Jefferson was among the most zealous believers that the fledgling nation should have a Bill of Rights, and a protection of expression should be first among those rights protected. A skeptical and perhaps prescient Alexander Hamilton had questions about the practical benefit of a 
declared right of free expression. Hamilton explained his position in the context of protecting the press:

Who can give it any definition which would not leave the utmost latitude for evasion? I hold it to be impracticable; and from this I infer, that its security, whatever fine declarations may be inserted in any constitution respecting it, must altogether depend on public opinion, and on the general spirit of the people and of the government. And here, after all, as intimated upon another occasion, must we seek for the only solid basis of all our rights. (Van Alstyne, 1984, p. 4)

Jefferson acknowledged these criticisms but supported these protections, nonetheless:

The declaration of rights, is, like all other human blessings, allowed with some inconveniences, and not accomplishing fully its object. . . But though it is not absolutely efficacious under all circumstances, it is of great potency always, and rarely inefficacious. A brace the more will often keep up the building which would have fallen, with that brace the less. (Van Alstyne, 1984, p. 4)

Not only was the concept of a constitutional protection for speech a revolutionary one, the procedure for implementing these protections, an independent judiciary, was a new concept as well. James Madison observed that if the Bill of Rights were added to the Constitution, "independent tribunals of justice will consider themselves in a peculiar manner the guardians of these rights" (Van Alstyne, 1984, p. 4).

The First Amendment states, "Congress shall make no law ... abridging the freedom of speech, or of the press; or the right of the people peaceably to assemble, and to petition the Government for redress of grievances."

Other amendments guaranteed state militias, due process, speedy public trials, jury trials in certain circumstances, and the right to be free from unreasonable searches and seizures as well as cruel and unusual punishments. Most of the Bill of Rights related to limitations on federal authority to interfere with individual rights.

The First Amendment's wording is unique among the Bill of Rights in its apparent clarity and strength. The other amendments in the Bill of Rights were worded to give government a degree of latitude when its action infringed on fundamental liberties. The Fourth Amendment conditions governmental searches and seizure on standards of probable cause and reasonability. Similarly, the Fifth Amendment allows one's life, liberty, or property to be taken as long as the government adheres to due process. The Eighth Amendment limitation on fines and bail is conditioned on them being excessive, and its proscription on punishments conditioned on them being cruel and unusual.

In contrast, the First Amendment's restriction on Congress is sweeping and unambiguous. Legal scholar William Van Alstyne (1984) explained, "It requires no arcane learning to understand the clear and plain meaning of 'Congress,' 'no 
law, 'abridging,' or 'speech.' To 'abridge' means not merely to forbid altogether but to curtail ... the imperative is simple, straightforward, complete and absolute" (p. 23).

Notwithstanding the First Amendment's wording, disputes over the extent of its protections started soon after ratification and continue to this day. In 1798, Congress enacted several laws known as the Alien and Sedition Acts designed to punish not only antigovernment conspiracies but political dissent against government officials (Alien and Sedition Acts, 1798; New York Times v. Sullivan, 1964). Outcry over prosecutorial abuses led to a Jeffersonian sweep in the elections of 1800 as antifederalists took control of Congress and Thomas Jefferson assumed the presidency. Most of the acts' provisions were either repealed or expired. The Supreme Court never officially overturned the act, but President Jefferson, calling it a "a nullity," pardoned those individuals sentenced under it and refunded their fines. In 1804, Congress also ordered that fines assessed from those prosecuted be returned (New York Times v. Sullivan, 1964). Almost two centuries later, the Supreme Court noted that there was a "broad consensus that the Act, because of the restraint it imposed upon criticism of government and public officials, was inconsistent with the First Amendment" (New York Times v. Sullivan, 1964, p. 276). The Court further noted that "[a]though the Sedition Act was never fully tested in this Court, the attack upon its validity has carried the day in the court of history" (New York Times v. Sullivan, 1964, p. 276).

\section{TH-CENTURY FOUNDATIONS}

Two crucial 19th-century legal developments had a profound and long-lasting effect on the application of First Amendment protections. Ironically, neither the 1803 Supreme Court decision in Marbury v. Madison nor the ratification of the Fourteenth Amendment in 1868 explicitly implicated the First Amendment.

The Marbury decision is a landmark because it established the doctrine of judicial review. That doctrine holds that the Supreme Court shall interpret the Constitution and statutes and invalidate those statutes in conflict with the Constitution (Marbury v. Madison, 1803). Since Marbury, the Supreme Court has struck down more than 130 federal laws and numerous state and local laws that contravened the Constitution. It was not until the 20th century, however, that the Court invalidated laws that impermissibly restricted free expression (Biskupic \& Witt, 1997).

The second 19th-century legal development that profoundly affected the future of the First Amendment was the ratification of the Fourteenth Amendment in 1868. Prior to its ratification, the Supreme Court held that the provisions of the Bill of Rights did not directly restrict state or local governmental conduct that impinged on the Constitutional rights of individuals (Barron v. Baltimore, 1833). Section 1 of the Fourteenth Amendment, which reversed that holding, provides in part: 
No State shall make or enforce any law which shall abridge the privileges and immunities of citizens of the United States; nor shall any state deprive any person of life, liberty, or property, without due process of law; nor deny to any person within its jurisdiction, the equal protection of the law.

Over time, this provision was used as a basis for guaranteeing that nearly every individual right found in the Bill of Rights applied to the conduct of state and local governments.

Notwithstanding the First Amendment's absolutist wording, the Supreme Court during the 20th century established various limitations on its protection of expression. In 1919, Supreme Court Justice Oliver Wendall Holmes coined this now famous axiom in Schenck v. United States: "The most stringent protection of free speech would not protect a man in falsely shouting fire in a theater and causing a panic" (p. 52). It was not, however, until 1925 that the Supreme Court actually held that the First Amendment rights of speech and a free press were "fundamental" ones protected by the Fourteenth Amendment from abridgment by state and local authorities (Gitlow v. New York, 1925).

Over the years, the Supreme Court has established new standards relating to expressive rights. Specifically, the Court has identified various circumstances where the government has greater latitude to interfere with expression. Those circumstances relate to the presence of either a compelling state interest, an unprotected area of speech, symbolic conduct, and criminality or the use of time, place, and manner restrictions. Generally, governmental regulations based on the content of the idea expressed will be overturned. In these instances, the standard that courts will employ is called strict scrutiny. Under this standard, the government must establish two things about official restrictions on expression for them to be held constitutional:

1. They are necessary to achieve a compelling state interest, and

2. they are narrowly tailored to achieve that compelling interest. (Widmar v. Vincent, 1981)

If expression falls under an "unprotected" area of speech, the government has far greater ability to regulate or proscribe it. Unprotected areas of speech include defamation, fraudulent commercial speech, obscenity, and incitement to criminality. Technically, another unprotected category called fighting words exists, but it is considered by many to be dormant because the Court has refused to invoke the category in upholding a speech restriction in five decades. Fighting words are those words which by their very utterance would arouse a violent response in a listener (Chaplinsky v. New Hampshire, 1942). Even so-called unprotected speech receives minimal protection. The government may not ban certain specific types of expression within an unprotected speech area because it disagrees with the viewpoint expressed. For example, whereas the government can ban obscene materials, the laws cannot single out certain obscene materials because they satirize government policies (R.A.V.v. St. Paul, 1992). By the same 
token, laws may punish incitement to criminality, but they can not single out for punishment only those who incite crime in opposition to a particular government policy, such as involvement in a war. If laws are to punish immediate calls to criminality, they must punish them without taking into account the unpopular viewpoint of the illegal agitator. The unprotected categories of speech that are of particular importance in the area of bigotry are fighting words, defamation, and criminal incitement.

\section{FIGHTING WORDS, OFFENSIVENESS, AND BREACHES OF THE PEACE}

The refusal to suppress offensive speech is one of the most difficult obligations the free speech principle imposes on all of us; yet it is also one of the First Amendment's greatest glories - indeed it is a central test of a community's commitment to free speech.

- Stanford Law School Professor Gerald Gunther, who escaped

Nazi Germany as a youth (Gunther, 1990)

I'm sure it makes a retarded person feel bad to be told he's stupid.... But you know that's life. We all put up with a lot of things we don't like.... There's really something seriously wrong with the people who believe it should be illegal to hurt a homosexual's feelings, or to stare at a pretty girl—or to call a person who wears glasses "four eyes" for that matter.

Neo-Nazi William Pierce (1995)

As stated above, fighting words are those words whose very utterance would likely lead to a violent response by the recipient. Presumably, then, very offensive speech then could often be banned as fighting words. Although the Supreme Court never officially abandoned this category, its recent opinions cast significant doubt on its continued vitality. First, the Supreme Court has failed to identify any fighting words fit for governmental proscription for nearly five decades. Second, the Court has since consistently held that the mere offensiveness of speech is not a basis for restricting it - a doctrine that appears to undercut the purpose of the fighting words exception in the first place.

When the first fighting words decision in Chaplinsky v. New Hampshire (1942) was handed down, the Court appeared to accept the notion that merely offensive speech might be punishable without contravening the First Amendment. Interestingly, 2 years prior, the Court in Cantwell v. Connecticut (1940) threw out the conviction of a religious preacher who was charged under a broad breach of the peace statute for playing bigoted and offensive recordings. A 
Jehovah's Witness who played a record called "Enemies" equating other religions such as Catholicism with the devil was convicted for his actions. The Court found that the preacher's individual religious and expressive rights were violated, even though his speech was "insulting to some religions."

In Chaplinksy, however, the Court upheld a breach of the peace conviction against a man for calling a city marshal a "damned racketeer and a damned fascist" after he was stopped for handing out literature on a city street (Chaplinsky, 1942, p. 569). The opinion indicated that the goals underlying First Amendment protections were not implicated because potentially injurious fighting words have such "slight social value as a step to truth that any benefit that might be derived from them is clearly outweighed by the social interest in order and morality" (Chaplinsky, 1942, p. 572).

Several years later, the Supreme Court overturned the breach of the peace conviction of "Father" Terminiello, an agitator who made a rabidly racist speech to a hall of supporters while a large hostile crowd amassed outside. In Terminiello v. Chicago (1949), the Supreme Court maintained that the trial judge's interpretation of the breach of the peace statute impermissibly punished speech "which stirs the public to anger, invites dispute, brings about a condition of unrest or creates a disturbance" (p. 4). The majority opinion found the judge's interpretation of the statute, which was relied on to convict the speaker, was overbroad. The legal doctrine of overbreadth in the First Amendment area means that a law punishes both speech that may be restricted along with protected speech that may not be curtailed. Laws that are overbroad will be overturned by courts.

The court failed to address whether Terminiello's speech was in fact protected, focusing instead on the faulty judicial interpretation of the statute. Disputing the trial court's reasoning, the Supreme Court majority in Terminiello v. Chicago, 1949, found that free speech is necessary to the operation of our societal institutions:

[A] function of free speech under our system of government is to invite dispute. It may indeed best serve its high purpose when it induces . . . unrest, . . . dissatisfaction ..., or even stirs people to anger. Speech is often protective and challenging. It may strike at prejudices and preconceptions and have profound unsettling effects as it presses for acceptance of an idea. (p. 4)

The Court's continuing difficulty in establishing a clear doctrine relating to breaches of the peace is reflected in Feiner v. New York (1951). There, the Supreme Court upheld a disorderly conduct conviction of a college student who ignored a policeman's order to stop speaking. The man, Irving Feiner, attempted to arouse a mixed race crowd through a combination of denunciations of political leaders and a plea to Blacks to take up arms in their struggle for equal rights. The majority maintained Feiner's arrest was to maintain order, not to squelch free speech. The dissent found that the facts of the case indicated no real threat to 
public order as the crowd was hardly aroused by the monologue. Justice Hugo Black, in a vigorous dissent, maintained the police's first obligation was to protect speakers from harm, not to silence them. After Feiner, though the Court's stance became more consistent, it tended to better protect public speakers in their expression of unpopular, even offensive, ideas. The Court abandoned the approach that the expression of mere ideas themselves could be punished as fighting words leading to breaches of the peace.

Toward the end of the century, the Court shifted profoundly toward new protection of offensive speech. In a Vietnam War-era case, Cohen v. California (1971), Paul Cohen challenged his conviction under a breach of the peace statute that criminalized "offensive conduct." Cohen was arrested for wearing a jacket reading "Fuck the Draft" as he walked the corridors of the Los Angeles Municipal Court. The Cohen case is considered a landmark not only because it squarely addressed the issue of offensive speech but also for its cogent analysis of a number of other significant free expression issues.

Justice Harlan, speaking for the majority, rejected a variety of assertions before addressing the issue of criminalizing offensiveness. He ultimately rejected the notion that government had authority to protect "unwilling or unsuspecting" people from receiving distasteful messages while in public places. This notion was summarized in another contemporary case: "We are often captives outside the sanctuary of the home and subject to objectionable speech," the Court held in a case from the previous year (Rowan v. Post Office Dept., 1970, p. 738). Seizing on that notion, Justice Harlan in Cohen (1970) maintained that those in public places "could effectively avoid further bombardment of their sensibilities simply by averting their eyes."

Justice Harlan was particularly forceful in dismissing California's most broad grab at power- the ability to punish speech on the basis of offensiveness, a notion that he labeled "inherently boundless":

\footnotetext{
How is one to distinguish this from any other offensive word? Surely the State has no right to cleanse public debate to the point where it is grammatically palatable to the most squeamish among us. For, while the particular four-letter word being litigated here is perhaps more distasteful than most others of its genre, it is nevertheless often true that one man's vulgarity is another's lyric. Indeed, we think it is largely because governmental officials cannot make principled distinctions in this area that the Constitution leaves matters of taste and style so largely to the individual. (Cohen v. California, 1971, p. 25)
}

In another landmark case, Texas v. Johnson (1989), the Supreme Court held that the Constitution protects even the most unpopular and offensive type of speech in a case involving flag burning. Gregory Lee Johnson was a young anarchist who took part in a series of roving political street protests to voice opposition to the policies of the Reagan administration and various corporations in Dallas in August 1984. In prior case law, the Supreme Court held that even though expression was most protected in public places, the government could 
still impose reasonable time, place, and manner restrictions to protect public safety and commerce-as long as those restrictions were not enforced to discriminate against unpopular speakers (Metromedia, Inc. v. San Diego, 1981). Furthermore, the Court offered limited protection to those who take part in symbolic speech - that is speech that is intertwined with physical conduct, such as marching or banner waving (United States v. O'Brien, 1968).

While protesting outside Dallas City Hall, Johnson displayed an American flag that had been stolen by another protester earlier in the day. He then held the flag up, drenched it in kerosene, and set it ablaze as the crowd proclaimed, "America, the red, white, and blue, we spit on you."

After the event, Johnson was charged and convicted under a Texas law that criminalizes the desecration of "venerated objects" such as monuments, houses of worship, and cemeteries. Also included as a protected object is "a state or national flag." Johnson was the only person at the event who was charged, and he faced only the single desecration charge. The statute said desecration of a covered object means to "deface, damage, or otherwise physically mistreat [it] in a way that the actor knows will seriously offend one or more persons likely to observe or discover his action." At trial, various observers to the flag immolation stated that they had indeed been "seriously offended" by it (Texas v. Johnson, 1989 , p. 399). Johnson was sentenced to 1 year in prison and assessed a $\$ 2,000$ fine (Texas v. Johnson, 1989, p. 400).

On appeal from the Texas state courts, the U.S. Supreme Court held that the law was unconstitutionally used against the flag burner. Technically, the appeal to the Supreme Court addressed only the narrow issue of the statute's application to Johnson. However, the reasoning of the opinion made it a virtual certainty that the Court would have thrown out the law if it had been asked to do so.

Texas offered two defenses for its prosecution of Johnson. First, it maintained that its prosecution protected against breaches of the peace. The Court maintained that at the time of the flag burning, no breaches of the peace actually occurred. The most authorities were able to establish was that some witnesses were offended. The Court noted that offensiveness was protected speech unlike incitement or fighting words. The Court stated that government may not "ban the expression of certain disagreeable ideas on the unsupported presumption that their very disagreeableness will provoke violence" (Texas v. Johnson, 1989, p. 409). The Court also mentioned the Texas appeals court observation that the law did not narrowly address those flag burnings likely to lead to serious breaches of the peace-but all offensive ones.

After rejecting Texas's contention that offensive flag burnings were equivalent to breaches of the peace, the Court addressed the state's second contention. Texas authorities also maintained that the state had an interest "in preserving the flag as a symbol of nationhood and national unity" (Texas v. Johnson, 1989, p. 410). The majority held that Texas's interest in that regard directly and impermissibly implicated the idea being expressed. The punishment unconstitutionally was linked to the unpatriotic idea associated with the flag's offensive destruction. 
Patriotic burnings of worn flags that conveyed respect for the national symbol would not be punished. Thus, the same act was being treated differently based on the particular idea promoted.

Because the state's action was based on the content of the idea expressed, the Court applied strict scrutiny analysis. Under strict scrutiny, the state must establish that its actions furthered a compelling state interest in the least restrictive way possible. The Court found, as it usually does when applying strict scrutiny analysis, that the state failed to meet its burden.

Justice William Brennan, speaking for the five-person majority, stated, "If there is a bedrock principle underlying the First Amendment, it is that the government may not prohibit the expression of an idea simply because society finds the idea itself offensive or disagreeable" (Texas v. Johnson, 1989, p. 414). He continued, "To conclude that government may permit designated symbols to be used to communicate a limited set of messages would be to enter territory having no discernible or defensible boundaries" (Texas v. Johnson, 1989, p. 414).

The majority also disputed Texas and the minority opinion's spirited contention that the American flag was in its own specially protected category. In a separate concurrence, Justice Anthony Kennedy described the majority decision "painful to announce." Perhaps recognizing the firestorm of popular criticism to come, Justice Kennedy attempted to explain the decision more in philosophical terms than technical legal ones:

Though symbols often are what we ourselves make of them, the flag is constant in expressing beliefs Americans share, beliefs in law and peace and that freedom which sustains the human spirit. The case here today forces recognition of the costs to which those beliefs commit us. It is poignant, but fundamental that the flag protects those who hold it in contempt. (Texas v. Johnson, 1989)

The Johnson case was a landmark for many reasons, and especially so for those studying extremism. It stands for the proposition that laws cannot single out the nonviolent expression of even the most offensive and disquieting ideas. In light of Cohen, Johnson, and other cases, it is reasonable to ask whether the unprotected speech category of fighting words still exists. Technically, it does because the category has never been officially overruled in any Supreme Court opinions. Realistically, however, subsequent case law to Chaplinsky and Feiner indicates that the conceptual undergirding to the fighting words category has been undermined to the point where current controlling case law is in conflict. That is probably why the Supreme Court has failed to identify and punish a fighting words utterance in half a century.

\section{LIES AND PUNISHMENT}

And I' $m$ in deep trouble for saying this around the world, that the eye-witnesses in Auschwitz who claim, like Elie Wiesel to have seen the gassings going on and the 
subsequent cremations, that they are liars. . . . He's a liar. And so are the other eye-witnesses in Auschwitz who claim they saw gassings going on because there were no gas chambers in Auschwitz, as the forensic tests show. And I've got into a lot of trouble saying this.

And there are so many survivors of Auschwitz now, in fact, that I get very tasteless about all of this. I don't see any reason to be tasteful about Auschwitz. It's baloney, it's a legend. . . . I'm going to form an Association of Auschwitz survivors, survivors of the Holocaust and other liars, or the A-S-S-H-O-L-S.

—British Holocaust denier David Irving (Irving v. Penguin and Lipstadt, 2000, § 8.17).

Our next topic involves the spreading of falsehoods, an undertaking certainly not limited to extremists. The law does not generally premise punishment of expression based on truthfulness. First Amendment protection of expression is not hinged on "the truth, popularity, or social utility of the ideas or beliefs which are offered" (NAACP v. Button, 1963, p. 445). The underlying notion of a marketplace of ideas implies that false ideas will be cast aside once the public is able to fully scrutinize them and contrast them with opposing truthful ones.

In some instances, however, the law allows governmentally sanctioned civil punishment of false statements, such as defamatory communications that injure someone's economic or reputational well-being. Defamation is a willful untrue statement communicated to someone else about a third party that harms the referenced person's reputation so that others will be less likely to associate or deal with him or her. Defamation that is written is called libel, whereas spoken defamation is known as slander. A person or business who is defamed may bring suit in civil court for monetary damages against those communicating the damaging falsehoods to others. Traditionally, false statements relating to such areas of promiscuity, disease, criminality, or dishonest business dealings have been the subject of defamation lawsuits.

The Supreme Court has applied certain requirements in defamation lawsuits. To ensure full and unfettered discussion on issues of public importance, the Supreme Court has created two distinct classes of plaintiffs. If someone is a public official or public figure, he or she has a higher burden to meet to successfully litigate his or her case. In the landmark decision in New York Times v. Sullivan (1964), a unanimous Supreme Court established that the First Amendment sets very high standards on what a government official must establish to prevail as a plaintiff in a defamation case. In addition to defamation, the law permits punishment of those who make false statements in official proceedings and fraudulent claims in the course of commercial transactions. A person who lies under oath during official government hearings, at civil or criminal trials, or during depositions before trial is guilty of perjury. Conceptually, the punishment of falsehoods in the context of defamation, perjury, or fraud could be extended to justify the notion that other harmful or untrue statements relating to racial or other groups should be punished as well. 


\title{
THE SHORT EXISTENCE OF AMERICAN GROUP LIBEL LAWS
}

\begin{abstract}
When this incident took place, about . . 4,000 Jews were not present simulataneously. . . . All of them were absent from the World Trade Center, although they were supposed to be there. So that's why they think that [the attack] might be from the Jews.
\end{abstract}

—Abdul Rasheed Ghazi, Pakastani Grand Mufti

(CNBC television broadcast, "Hardball," September 27, 2001)

If you want to learn and understand why the jews can commit such insane crimes as ritual murder, you must know the jewish secrets.

—“Jewish Murder Plan Against Gentile Humanity Exposed” (Jew Watch, 1992)

Are ideological falsehoods injected into public discourse categorically different from those more narrowly targeted to affect an individual's reputation or economic status? Or conversely, can lies in the area of public discussion render benefits to society, as Mill (1859/1983) suggested, by causing "the clearer perception and livelier impression of truth, produced by its collision with error?" (chap. 2). Specifically, if the government allows punishment of those who spread injurious defamatory falsehoods about one's business or reputation, why can it not also punish damaging falsehoods relating to racial, religious, and other minority groups? The counterargument is simple: The nonviolent expression of racially based lies and hatred represents broad social and political expression that, although reprehensible, is nonetheless appropriate for the marketplace of ideas, where people of intellect and goodwill rightfully reject it.

In the aftermath of violent race rioting, Illinois passed a "group-libel" statute that punished those who make bigoted "defamatory" statements against racial, religious, or ethnic groups. Several other jurisdictions followed, with New Jersey passing a similar law in 1934. The New Jersey Supreme Court overturned its state law in 1941 on state and federal constitutional grounds. The case involved a prosecution of German American Bund officials (State v. Klapprott, 1941). Although Massachusetts passed a group libel law in 1943 and Indiana passed one in 1947, attempts in other states and at the federal level failed. Even in states where group libel laws existed, they were rarely used (Walker, 1994).

In Beauharnais v. Illinois (1952), the U.S. Supreme Court affirmed Illinois's group libel statute. Although never technically overturned, subsequent U.S. Supreme Court decisions have clearly rejected all the foundational arguments that were relied on in the Beauharnais decision, and the case is no longer regarded as sound law. Illinois's group libel law was repealed in 1961 (Walker, 1994). 


\section{GROUP LIBEL IN CANADA AND EUROPE}

Other western nations with less stringent protections of free speech than the United States, however, presently have group libel or hate speech laws on the books. Canada, the United Kingdom, Germany, and France, among others, have criminal statutes that punish such things as Holocaust denial and fomenting racial hatred, but with the exception of Germany, these laws are rarely enforced. Section 318 of the Canadian Criminal Code criminally punishes those who "advocate genocide" on the basis of color, race, religion, or ethnic origin. Section 319(1) punishes those who incite hatred on the basis of color, race, religion, or ethnic origin where such incitement is likely to lead to a breach of the peace. Section 319(2) of the Canadian Criminal Code punishes the public communication of statements that willfully promote hatred on the basis of color, race, religion, or ethnic origin.

The United Kingdom's primary racial hatred laws are located in Part III of the Public Order Act 1986 ([1]§§17 et. seq.) and Part II of the Crime and Disorder Act of 1998 (U.K. Public Order Act of 1986; U.K. Crime \& Disorder Act of 1998). These statutes punish such things the violence and incitement of racial hatred through words, conduct or the display of written material. The laws expansively defines race as including color, race, nationality (including citizenship) and ethnic or national origins.

Germany also has a criminal law that punishes inciting racial hatred. In 1996, American Gerhard Lauck was sentenced to 4 years in prison by a German court after he was apprehended by authorities during a European trip. Lauck was convicted for the mass mailing of hateful neo-Nazi materials to Germany, where it is banned, from his home in Nebraska, where it is legal (Associated Press, 1996). Article 5 of the German Constitution provides limited protection for free speech but only to the extent that the expression is truthful and does not contravene the human rights of others (Kessler \& Rosenberg, 2000).

\section{GOOD, EVIL, AND ADVOCACY}

The Americans must know that the storm of airplanes will not stop, God willing, and there are thousands of young people who are as keen about death as Americans are about life.

Al Qaeda spokeman Sulaiman Abu Ghaith. (Al Jezerra television broadcast, October 14, 2001)

We grid for total war against the Jews and the rest of the goddamned mud races of the world-politically, militantly, financially, morally, and religiously. In fact we regard it as the heart of our religious creed, and as the most sacred credo of all. We 
regard it as a holy war to the finish—a racial holy war. RAHOWA! [acronym for racial holy war] is INEVITABLE.

-Ben Klassen (1987), deceased founder of the original Church of the Creator, whose adherents have been implicated in race murders and other crimes (Southern Poverty Law Center, 1999, p. 29)

\begin{abstract}
The scene in the courtyard was one of utter devastation. The Pennsylvania Avenue wing of the [FBI Headquarters] building, as we could then see, had collapsed, partly into the courtyard in the center of the building and partly into Pennsylvania Avenue. A huge, gaping hole yawned in the courtyard pavement just beyond the rubble of collapsed masonry, and it was from this hole that most of the column of black smoke was ascending.
\end{abstract}

—Description of early morning ammonium nitrate and fuel oil truck bombing by White supremacist terrorist in novel The Turner Diaries-one of Timothy McVeigh's favorite books (Macdonald, 1978)

I tried to use an adventure story as a medium for my message.

Neo-Nazi leader William Pierce explaining the purpose of his book, The Turner Diaries (Nazi America, A Secret History, 2000).

An important free speech issue relevant to bigotry is that of advocacy. As we have seen, the Supreme Court has adopted the view that the First Amendment protects offensive, even vulgar speech, to ensure a full spectrum of expression. In a series of cases starting right after World War I, the Court was forced to deal with people who were charged with promoting harmful ideas that encouraged such things as violence, toppling the government, or opposition to the draft. These prosecutions did not occur in a vacuum. In response to successful communist movements in Europe and our war efforts against Germany, many dissenters expressing unpopular political views were targeted for prosecution as well as others who actually engaged in violent acts. Beginning in 1919, Attorney General A. Mitchell Palmer started a massive 2-year long roundup of leftists during the period known as the "Red Scare." The prosecutions largely targeted dissent and involved abuses of the legal and procedural safeguards intended to protect criminal defendants. The prosecutions also were used as a pretext to deport recent immigrants who were expressing unpopular views. Politically influenced prosecutions involving expressive or associational rights would later target Jehovah's Witnesses during the 1930s and 1940s, bigots and reactionaries during the 1920s and 1930s, leftists and communists in the 1940s and 1950s, and liberal civil rights and antiwar activists in the 1950s and 1960s.

The Supreme Court, under the ominous backdrop of the Red Scare, addressed free speech protections for the very first time in Schenck v. United 
States (1919). Schenck and others were charged with conspiring to violate Title I of the Espionage Act of 1917, which stated in part,

Whoever, when the United States is at war, shall willfully cause or attempt to cause insubordination, disloyalty, mutiny, or refusal of duty in the military or naval force of the United States, or shall willfully obstruct the recruiting or enlistment service of the United States, to the injury of the service or of the United States, shall be punished by a fine of not more than $\$ 10,000$ or imprisonment for not more than twenty years, or both.

Schenck and his codefendants were convicted under the act for distributing leaflets critical of the draft. Labeling the draft as "despotism" in its worst form, the leaflets urged citizens to peacefully attempt repeal of the draft laws. It further counseled, "Do not submit to intimidation . . . assert your opposition to the draft.“

In a unanimous opinion, Justice Oliver Wendall Holmes held the law to be constitutional:

The question in every case is whether the words used are used in such circumstances as to create a clear and present danger that they will bring about the substantive evils that Congress has a right to prevent. It is a question of proximity and degree. When a nation is at war many things that might be said in a time of peace are such a hindrance to its effort that their utterance will not be endured so long as men fight. (Schenck, 1919, p. 52)

The Schenck decision established the first constitutional standard used to determine when advocacy of ideas may be criminally punished. This "clear and present danger" standard allowed governmental punishment of expression when the speech created a clear and present danger of unlawful conduct. In Schenck, though, the defendants were critical of government institutions, and their statements urged change through lawful, nonviolent use of the legislative process. In reality, the Schenck standard was used over the years, in various permutations and contortions, to justify the criminalization of simple dissent to government policies themselves.

In Abrams v. United States (1919), Justice Holmes dissented against a narrowing of the clear and present danger standard to include punishment for speech that merely has a "bad tendency":

The ultimate good desired is better reached by free trade in ideas - that the best test of truth is the power of the thought to get itself accepted in the competition of the market ... that, at any rate, is the theory of our Constitution. . . I think that we should be eternally vigilant against attempts to check the expression of ideas we loathe and believe to be fraught with death, unless they so imminently threaten immediate interference with the lawful and pressing purposes of the law that an immediate check is required to save the country. (p. 630) 
Gitlow v. New York (1925) was the first of a series of cases over a 40-year span where the Court was asked to assess "criminal anarchy" or "syndicalism" statutes. These statutes specifically punished in their text the advocacy of violence as a means of governmental, political, or social reform. New York's criminal anarchy law punished those who advocated the overthrow of the government by force or violence. Gitlow was a socialist convicted of criminal anarchy for his part in publishing "the left-wing manifesto" that called for revolutionary action by such means as coordinated work stoppages.

Although the Court ruled against Gitlow, the decision had important broad implications for the protection of individual liberties. The Gitlow (1925) decision was the first where the Supreme Court held that the

freedom of speech and of the press which are protected by the First Amendment from abridgment by Congress - are [also] among the fundamental personal rights and "liberties" protected by the due process clause of the Fourteenth Amendment from impairment by the states.

Thus, the Court recognized for the very first time that states were also limited in how they restricted certain fundamental liberties found in the Bill of Rights.

This important finding was of little consequence to Benjamin Gitlow, whose conviction was affirmed. The Court refused to invoke the "clear and present danger test" by distinguishing between the Federal Espionage Law and New York's Criminal Anarchy Statute. Because laws, like the espionage statute, punished specific acts without referencing speech in particular, the Court maintained the clear and present danger test was appropriate to establish when speech is covered under the statute's scope. In this case, however, the legislature already determined that this type of advocacy was particularly harmful and in fact specifically prohibited it by statute. The Supreme Court maintained it was not the judiciary's function to second-guess the findings of the legislature in its decision to punish utterances "of substantive evil." Justice Holmes, in his dissent, maintained that the clear and present danger test should be invoked and that Gitlow's documents under that standard were simply not enough of a threat to warrant criminal sanction.

In a related case 2 years later, the Court affirmed the conviction of a woman under California's Criminal Syndicalism Act. In Whitney v. California (1927), the Court found that the defendant's mere membership in the Communist Labor Party was enough for her to be constitutionally convicted of a crime. The majority rejected Whitney's speech and association claims, even though she personally proposed nonviolent party resolutions that ran counter to the organization's unlawful goals.

The Court did overturn a few criminal syndicalism convictions after Whitney, however. The most notable case was Herndon v. Lowry (1937), where the Court abandoned the "bad tendency" guidelines articulated a decade prior in the 
Gitlow case. In Herndon, the defendant's conviction for "attempting to incite insurrection" was thrown out because the risk from his words was not immediate in nature.

A new and significantly revamped version of the clear and present danger standard was unveiled in Dennis v. United States (1951). In Dennis, the criminal defendants were convicted under the federal Smith Act of 1940-a law substantially similar to the criminal anarchy statute at issue in the Gitlow case. The defendants were found to have conspired to organize an American Communist Party with the eventual aim of a forceful overthrow of the U.S. government. The Court invoked Court of Appeals Judge Learned Hand's new version of the clear and present danger test: "In each case [courts] must ask whether the gravity of the 'evil' discounted by its improbability, justifies such invasion of speech as is necessary to avoid danger" (Dennis, 1951, quoting 183 F. 2d 201, 212 [2nd Cir. 1950]).

In this incarnation of the clear and present danger test, the Court allowed a gravely evil threat to be punished irrespective of its imminency or probability. Chief Justice Vinson explained why:

Obviously, the words [of the test] cannot mean that before the government may act, it must wait until the putsch is about to be executed, the plans laid and the signal is awaited. . . Certainly an attempt to overthrow the Government by force, even though doomed from the outset because of inadequate numbers or powers of revolutionists, is a sufficient evil for Congress to prevent. The damage which such attempts create both physically and politically to a nation makes it impossible to measure the validity in terms of the probability of success, or the immediacy of a successful attempt. (Dennis v. United States, 1951)

In Yates v. United States (1957), the Court interpreted Congress's "intent in formulating the Smith Act to only cover speech that actually promoted illegality, rather than abstract support for the use of illegal means as a general concept."

In 1969, the Supreme Court finally arrived at its present standard for determining when politically harmful advocacy may be criminalized. In doing so, it identified the unprotected area of speech now known as criminal incitement. In Brandenburg v. Ohio (1969), the Court was asked to review the conviction of a $\mathrm{Ku}$ Klux Klan leader prosecuted under a state criminal syndicalism statute.

\section{THE CURRENT STANDARD: IMMINENT INCITEMENT}

In the early 1960s, Klansman Clarence Brandenburg invited a television news crew to film a Ku Klux Klan rally on a private farm in Hamilton County, Ohio. The prosecution of Brandenburg was based primarily on news footage taken at the private event where only Klansmen and the news crew were present. Footage from the rally aired on both local and national news broadcasts. The footage showed a dozen people with hoods assembled around a large wooden 
cross, which was set ablaze. Some of the Klansmen appeared to be armed, and the microphone picked up only "scattered phrases" that derided African Americans and Jews.

Elsewhere in the film, Brandenburg addressed the assemblage unarmed but dressed in full Klan regalia. In a speech at the rally he said,

This is an organizer meeting. ... The Klan has more members in the State of Ohio than does any other organization, but if our President, our Congress, our Supreme Court, continues to suppress the white, Caucasian race, it's possible that there might have to be some revengeance [sic] taken. We are marching on Congress July the Fourth, four hundred thousand strong. From there we are dividing into two groups, one group to march on St. Augustine, Florida, the other group to march into Mississippi. Thank you. (Brandenburg, 1969, p. 446)

Later, Brandenburg added the following opinion to a substantially similar statement at the same event: "Personally, I believe the nigger should be returned to Africa, the Jew returned to Israel" (Brandenburg, 1969, p. 446).

Brandenburg was convicted under Ohio's Criminal Syndicalism Act, a law nearly identical to the California statute affirmed in Whitney v. California (1927). Ohio's law punished

advocat[ing] ... the duty, necessity, or propriety of a crime, sabotage, violence, or unlawful methods of terrorism as a means of accomplishing industrial or political reform [and for] voluntarily assembl[ing] with any society, group, or assemblage of persons formed to teach or advocate the doctrines of criminal syndicalism.

Brandenburg was sentenced to 10 years in state prison and assessed a $\$ 1,000$ fine for his conduct at the rally.

A unanimous Supreme Court overturned the statute, without even applying it to Brandenburg's speech. The opinion articulated what is now the current test to determine the contours of lawful advocacy and illegal incitement to criminality. In order for dangerous advocacy to be classified as illegal incitement, two conditions must be met. First, the speech must be directed to inciting or producing imminent lawless action, and second, the speech must be likely to incite or produce such action.

\section{WORDS AS CRIME}

REGUARDING [sic] YOUR RESPONSE TO THE LAKE Co. SHERIFFS POSSE COMITATUS, THAT WAS YOUR SIGNATURE TO YOUR DEATH WARRANT.

YOU WILL HANG SHORTLY, IF YOU LIVE LONG ENOUGH 
YOUR TREASON WILL BE REWARDED JUST AS TREASON WAS 200 YR [sic] AGO.

- Handwritten death threat from racist antitax Posse Comitatus member to unidentified U.S. senator in 1976 (Ridgeway, 1995, p. 128)

In the last section, we examined types of expression that are considered unprotected areas of speech. Some communications are considered so dangerous by their very nature that the law views them primarily as criminal conduct rather than expressive speech. The most prominent examples of this are threats, conspiracies, and criminal solicitation.

In law, a threat is defined as a statement communicating an intent to injure another or damage the property of another. The Supreme Court addressed the issue of criminalizing threats in Watts v. United States (1969), where an African American Vietnam War protester was convicted under a law making it a crime to threaten the life of the president. In August 1966, at a Washington, D.C., rally Watts stated,

And now I have already received my draft classification as 1-A and I have got to report for my physical this Monday coming. I am not going. If they ever make me carry a rifle the first man I want to get in my rifle sights is L.B.J. [President Lyndon Johnson]. They are not going to make me kill my black brothers. (p. 706)

Unbeknownst to Watts, an investigator with the Army Counter Intelligence Corps secretly noted what he was saying. Based on those remarks, Watts was convicted by a jury during a federal trial in Washington, D.C.

The Supreme Court threw out Watts's conviction but upheld the law. Watts's statement was deemed by the Court to be a "crude offensive" political statement of constitutionally protected speech rather than a genuine threat. The Court said that whereas the law itself was constitutional, its application to Watts's political expression was not. The government has an overwhelming interest in both protecting the president's life and in allowing him to perform his duties without the obstruction that results from violent threats, the Court found. In contrast, the Court also invoked its Sullivan ruling in analyzing Watts's statement: "[There is] a profound national commitment to the principle that debate on public issues should be uninhibited, robust, and wide open, and that it may well include vehement, caustic, and sometimes unpleasantly sharp attacks on government and public officials" (Watts v. United States, 1969, p. 708).

Threats are not the only kinds of statements that are criminal by their very nature. Conspiracies and criminal solicitation have traditionally been regarded as crimes. A conspiracy is an agreement by two or more people to commit a crime or to solicit or aid others in the commission of a crime (Model Penal Code $\S 5.03)$. Some conspiracy statutes also require an overt step in furtherance of the planned offense by one of the parties, although that step could be a very small one such as obtaining a tool or drawing a sketch. Conspiracy prosecutions do not 
require that the target crime ever be carried out. In contrast to incitement prosecutions, then, there is no requirement of imminency at all for a conviction to take place. Conspiracy is a separate offense from the crime actually planned by the instigators. Criminal solicitation punishes those who ask, direct, or encourage another to commit a crime (Model Penal Code $\S 5.02$ ).

\section{TARGETING GROUPS}

Only God has the right to create a race—not no black and white, not no n—ger, not no Jew. Yes I will use the word n-ger, because its not illegal. ... Take a stand, join the Klan. Take a stand, join the Klan. It is not against the law to join the Klan!

—Jeff Berry, Imperial Wizard, American Knights of the Ku Klux Klan, speaking at Butler, Pennsylvania, rally, March 1998 (Thompson \& Weller, 1998, p. 43)

Over the past several decades, the Supreme Court has held that the government can neither outlaw organizations nor criminalize group membership if there is no connection to any illegality. Still, the First Amendment's right to associate clearly does not extend to every associational relationship. Group members, for instance, do not have the right to plan or commit crimes and terrorism, form private armies, or conduct fraudulent activities. In addition, it is increasingly common for groups and their leaders to be held civilly liable for the conduct of group members.

Neither groups nor their members can be criminally sanctioned without proof of active illegal conduct or unlawful incitement (Noto v. United States, 1961). Even when groups engage in criminality, individual people cannot be summarily punished for a relationship with or membership in that group. To be punishable, a person associated with an illegal group must be aware of the group's criminality and must specifically intend to further the criminality (Tribe, 1988).

American law was not always as tolerant of organizations disfavored by the government. As a response to Klan violence in the early 1920s, various jurisdictions passed laws designed to specifically combat the Klan. Antimasking laws, which are still on the books today, were enacted in various states. These laws prohibit the nontheatrical wearing of masks in public. Municipal authorities with substantial Catholic populations from New England to the Great Lakes region confiscated Klan materials or banned the group from meeting or parading (Walker, 1994). In 1923, New York enacted a sweeping anti-Klan statute that compelled various "oath-bound" groups deemed illegitimate by the state to register with authorities and disclose their membership. The statute also banned wearing masks in public. In 1928, the U.S. Supreme Court upheld New York's restrictions on governmentally disfavored organizations, like the Klan, on the grounds that it was proper to do so as a legitimate exercise of state authority 
(Bryant v. Zimmerman, 1928). By the late 1920s, however, it was not anti-Klan statutes that would cripple the Klan, but rather journalistic and congressional investigations, internal quarrels, corruption, and highly publicized sex scandals (Bullard, 1991).

After a lengthy period where governmental abuse of extremists and dissenters was judicially sanctioned, the Supreme Court changed its course. In 1958, the Supreme Court revisited a state statute similar to the one at issue in Bryant. The 1958 controversy involved Alabama's attempt to compel disclosure of the NAACP's membership lists. In NAACP v. Alabama (1958), the U.S. Supreme Court overturned its decision in Zimmerman. The Court held that concomitant with the freedom of association guaranteed by the First Amendment is the right to privacy in those associations, and the state's interest in disclosure simply did not overcome that privacy right (NAACP v. Alabama, 1958). In subsequent cases, the Supreme Court severely limited the government's ability to interfere with unpopular groups without a direct connection to criminality.

The criminal law, however, has traditionally targeted various types of group conduct that directly further criminality as well as those who actually commit the prohibited act. Conspiracy is a traditional common law crime that is punished by all states and the federal government. In addition, accomplice liability can extend to those who "aid and abet" by purposefully assisting others in the commission of a crime or their flight from it (Black's Law Dictionary, 1983, p. 37). More spontaneous conduct involving groups such as incitement, riot, and unlawful assembly is also punished by the criminal law. Riot and unlawful assembly punish various types of disorderly conduct that cause either substantial public inconvenience or threaten public safety (Model Penal Code $\S 250.1$ ). Many states and the federal government punish "misprision of felony." The statute was used to prosecute Timothy McVeigh's friend, Michael Fortier, for failing to alert authorities of what he knew after the Oklahoma City bombing (United States v. Fortier, 1998). The federal version punishes those who, having knowledge about a federal felony, conceal this knowledge after the crime by not alerting authorities (18 U.S.C. § 4).

In 1970, Congress passed the first federal Racketeer Influenced and Corrupt Organization (RICO) law as part of the Organized Crime Control Act, 18 U.S.C. 1961-1968, to address ongoing criminal activities by organized groups like the Mafia. RICO law punishes those formal or informal enterprises that employ a pattern of racketeering activity. Of particular relevance to antiterrorism efforts, racketeering encompasses acts or threats involving murder, kidnapping, arson, and robbery. Federal RICO law does not preclude the charging of separate substantive offenses under state law that constitute the pattern of racketeering activity.

Federal RICO statutes were used to prosecute members of a terrorist White supremacist gang known as the Order in the 1980s who engaged in murder and robbery. By 1986, more than two dozen states passed RICO laws modeled after the federal legislation (Zawitz, 1988). The Supreme Court has held that federal 
RICO law covers conduct beyond crimes for economic gain including political extremists. In N.O.W. v. Scheidler (1994), a group of health care facilities successfully argued that a coalition of antiabortion groups, including the Pro Life Action Network, took part in a national conspiracy to illegally force the closure of abortion clinics in violation of RICO.

In a similar vein, various jurisdictions have recently enacted "gang enhancement" statutes that target criminal associations like skinhead groups and urban street gangs. These laws increase the penalty for those who are proven to commit crimes in groups.

As the Constitution requires, these statutes do not punish mere association. California's gang enhancement, Penal Code $\S 186.22$, for example states,

Any person who is convicted of a felony committed for the benefit of, at the direction of, or in association with any criminal street gang, with the specific intent to promote, further, or assist in any criminal conduct by gang members, shall, upon conviction of that felony, in addition and consecutive to the punishment prescribed for the felony or attempted felony of which he or she has been convicted, be punished by an additional term of one, two, or three years at the court's discretion.

The statute defines "criminal street gang" as any ongoing organization, association, or group of three or more persons, whether formal or informal, having as one of its primary activities the commission of ... [various offenses]. California's law requires knowledgeable and active assistance of the criminal enterprise in the commission of a crime.

\section{CIVIL LAWSUITS AGAINST EXTREMIST GROUPS}

Don't think that with the recent court proceedings levied against the White Aryan Resistance in Portland, Oregon, that our activities will cease. In fact this case has convinced us to go the extra mile, take the extra step. We will create a revolution in this country, we will put blood on the streets like you've never seen and advocate more violence than both World Wars put together.

-White Aryan Resistance, Orange County, California, telephone hotline message discussing an Oregon jury's assessment of a multimillion dollar verdict against the group and its leaders (personal communication, October 26, 1990)

A significant obstacle to the operations of many prominent right-wing extremist groups came not only from prosecutors but private lawyers as well. Starting in the late 1970s, the Alabama-based civil rights group Southern Poverty Law Center pioneered a strategy of suing hate groups civilly under traditional tort law claims relating to agency and negligence theories for their part in promoting hate violence. Staggering monetary judgments, usually far in excess of the groups' assets, bankrupted various Klan factions and neo-Nazi groups 
TABLE 1: Major Civil Lawsuits Against Racist Hate Groups, 1980-2000

\begin{tabular}{|c|c|c|c|}
\hline Year & Group/Trial Location & Wrongful Act & Judgment/Result \\
\hline 1981 & $\begin{array}{l}\text { Texas Emergency Reserves } \\
\text { (KKK militia) }\end{array}$ & Intimidation & $\begin{array}{l}\text { Organization disbanded by court } \\
\text { order }\end{array}$ \\
\hline 1985 & $\begin{array}{l}\text { Confederate Knights/White } \\
\text { Patriot Party (Alabama) }\end{array}$ & Intimidation & Court enjoins paramilitary actions \\
\hline 1987 & $\begin{array}{l}\text { United Klansmen of America } \\
\text { (Alabama) }\end{array}$ & Homicide & $\$ 7$ million (organization disbands) \\
\hline 1988 & Invisible Knights KKK (Georgia) & Assaults & $\begin{array}{l}\$ 1 \text { million (organization disbands } \\
\text { in 1991) }\end{array}$ \\
\hline 1990 & White Aryan Resistance (Oregon) & Homicide & $\$ 12$ million (ongoing restitution) \\
\hline $\begin{array}{r}1992- \\
1995\end{array}$ & Church of the Creator (Florida) & Homicide & $\begin{array}{l}\$ 1 \text { million (organization } \\
\text { temporarily disbands) }\end{array}$ \\
\hline 1998 & $\begin{array}{l}\text { Christian Knights KKK } \\
\text { (South Carolina) }\end{array}$ & Church arson & $\begin{array}{l}\$ 37.8 \text { million (reduced on appeal } \\
\text { to } \$ 21 \text { million) }\end{array}$ \\
\hline 2000 & Aryan Nations (Idaho) & Assaults & $\$ 6$ million (organization disbands) \\
\hline 2000 & Klansman Jeffrey Berry & Assault et al. & Default judgment of $\$ 120,000$ \\
\hline
\end{tabular}

SOURCE: Published and unpublished material on file at the Center for the Study of Hate and Extremism, California State University, San Bernardino.

NOTE: Year is for judgment. Dollar amount represents total award against all defendants, not just organization. Wrongful act refers to precipitating event and not necessarily the particular cause of action.

including White Aryan Resistance, the Church of the Creator, and most recently, Aryan Nations (see Table 1).

In October 2001, an unidentified widow became the first individual to file a lawsuit arising out of the World Trade Center attacks suing Osama bin Laden and his organization as well as the Taliban for $\$ 5$ billion. (Associated Press, 2001) In February 1998, Stephen Flatow won a $\$ 247$ million against the government of Iran in a lawsuit in federal district court. Flatow's daughter Alisa, a Brandeis University student visiting Israel for religious study, was killed by a bomb that destroyed a bus she was on in Israel. Flatow sued pursuant to a 1996 antiterrorism law that allows lawsuits against foreign entities connected to terrorism (Jacoby, 1999).

Torts are wrongful acts for which the law recognizes a compensatory or remedial civil remedy - usually money damages. Tort law doctrine allows civil liability for wrongful acts to extend beyond the actual aggressors to those who intentionally or negligently further the commission of the wrongdoing, such as those who negligently or malevolently train or supervise others. Negligence occurs when an unreasonable act results in a foreseeable harm to another. The standard of proof a litigant needs to prevail in civil tort cases is that of preponderance of the evidence - a much lower evidentiary standard than the one used in criminal trials. In addition, tort law allows an additional monetary recovery in the form of punitive damages to punish wrongdoers. These awards are generally 


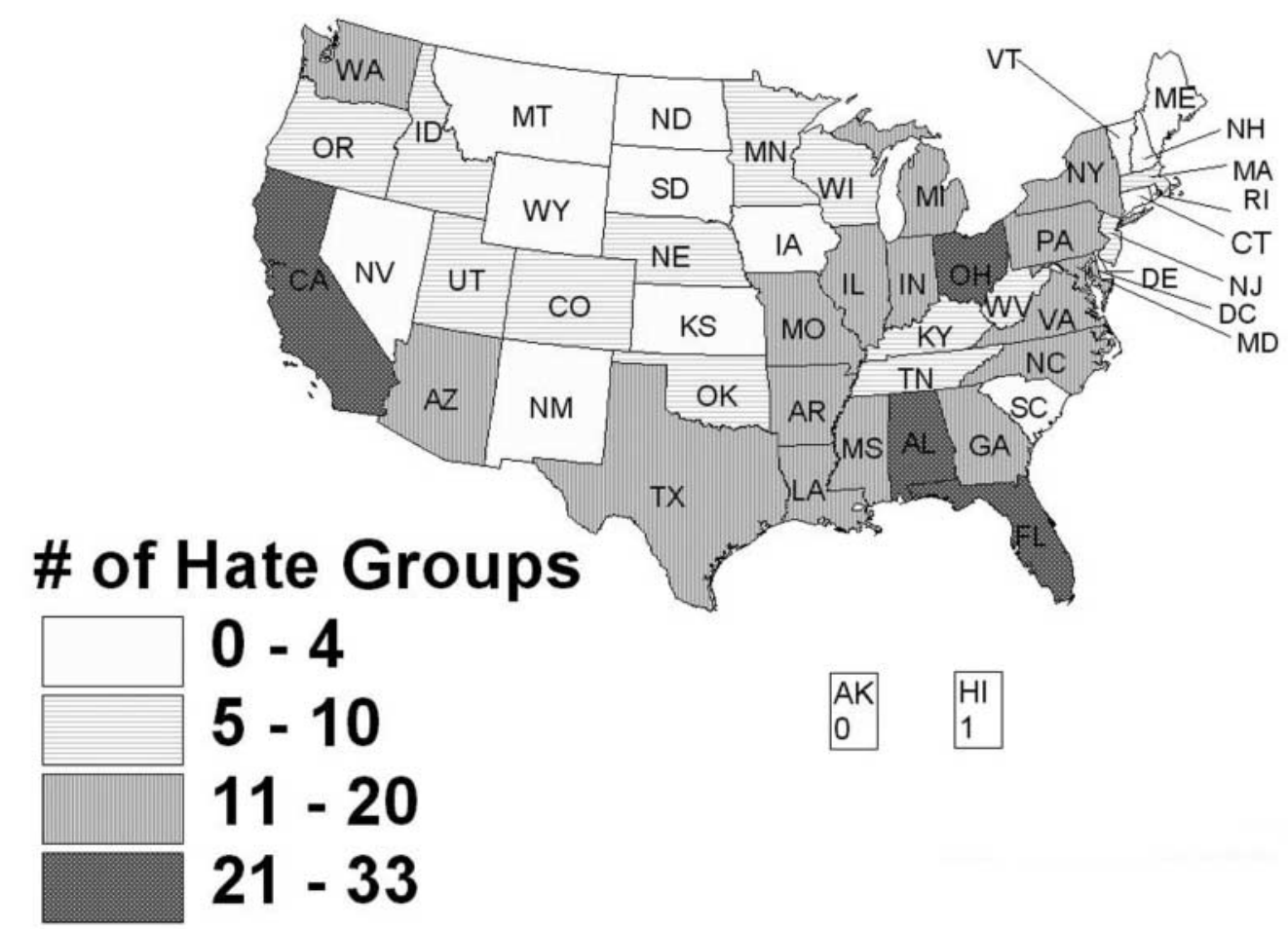

Figure 1: Hate Groups in the United States by State, 1999

J SOURCE: Southern Poverty Law Center (2000). Map generated by Quyen Nhu Nguyen. 
offered for intentional torts and in negligence cases where the conduct is viewed as particularly blameworthy_characteristics commonly found in hate violence and terrorism cases (Edwards \& Edwards, 1998).

\section{UNAUTHORIZED MILITIAS}

The Militia of Montana is against an immoral, illegitimate, bastardized form of government. We believe in the ballot box; we believe in the jury box. We will not give up the cartridge box in the event the first two boxes do not work.

—“Taking Aim” (1994)

A well regulated militia, being necessary to the security of a free State, the right of the people to keep and bear arms, shall not be infringed.

—Second Amendment, U.S. Constitution

The government also has broad authority to restrict groups when they engage in conduct that is uniquely within the province of the state. When citizens band together to form private armies or militias, as many hate groups and extremists have done, the government has full authority to disband them and prosecute their members. The federal government and the various states all have laws related to militias. The federal government, for instance, divides the militia into two classes - the organized and the unorganized militia. The organized militia consists of the National Guard and the naval militia, whereas the unorganized militia consists of all able-bodied males ages 17 to 45 not otherwise engaged in active military service or the National Guard (10 U.S.C. $§ 311$ ). Notwithstanding the claim of various unauthorized militia members, membership in the unorganized militia does not confer any right to organize or own guns. Rather, these laws provide an alternate way for the government to call citizens into mandatory service should exigent circumstances require it.

More than 100 years ago in Presser v. Illinois (1886), the Supreme Court held,

The right voluntarily to associate together as a military company or organization, or to drill or parade with arms, without and independent an act of Congress or law of the State authorizing the same, is not an attribute of national citizenship. Military organization and military parade under arms are subjects especially under the control of the government of every country. They cannot be claimed as a right independent of law. Under our political system they are subject to the control of the State and Federal Governments, acting in due regard to their respective prerogatives and powers. The Constitution will be searched in vain for any support to the 
view that these are privileges and immunities of citizens of the United States independent of some specific legislation on the subject.

Today, 41 states have laws banning private armies or certain types of dangerous paramilitary training. There is also a federal law that bans certain types of paramilitary training designed to foment civil disorder. The federal law only punishes instructors, and attempts at a federal ban on private militias failed after the Oklahoma City bombing. Recent efforts to enact additional federal legislation relating to militia's organizing have failed (Halpern \& Levin, 1996).

Until recently, contrary to popular opinion, most legal scholars and every federal court ruling have supported the view that the Second Amendment's "right to bear arms" clause does not support an unfettered right to personal gun ownership - either individually or in an unregulated militia group. In 1999 a federal district court judge in Texas issued a sweeping decision invalidating a firearms law on the grounds that the Second Amendment does not generally allow such restrictions on private gun ownership. On appeal in October 2001, however, the United States Court of Appeals for the Fifth Circuit, in a ruling only affecting the middle South, held that the Second Amendment does protect an individual right to gun ownership. It further held that the right is subject to narrowly tailored government regulation that can restrict private gun ownership in some circumstances (United States v. Emerson, 2001). Previously, every federal court decision rejected the contention that the Second Amendment provides a "fundamental" right to individual gun ownership by holding that the provision applies to a state's right to maintain a militia or "national guard."

The Second Amendment's failure to achieve Supreme Court approbation as a fundamental right is significant. When a right is found to be fundamental by the Supreme Court, the government's ability to interfere with that right is severely restricted absent a showing of the furtherance of a compelling governmental interest and a limited application of the interference. Furthermore, in nearly every instance that a right has been found to be a fundamental one, the limitation placed on government authority was held to apply not only to the federal government but to the states as well. Unless their state constitution forbids it, states outside of the Fifth Circuit are currently free to protect or restrict private gun ownership as they see fit. The U.S. Supreme Court has consistently refused to invalidate federal firearm laws on Second Amendment grounds. Federal courts have also upheld state laws banning unauthorized paramilitary activity, and the Supreme Court let stand a municipal law that virtually banned private gun ownership (Person v. Miller, 1988; Quilici v. Village of Morton Grove, 1983; Vietnamese Fishermen's Association v. Knights of the Ku Klux Klan, 1982). Although the U.S. Supreme Court has consistently refused to invalidate gun control measures on Second Amendment grounds, it has not definitively stated the precise counters of the amendment. 


\section{HATE CRIME LAWS}

Hate crime laws assume that the greater the harm to offenders, the greater the good to victims. But viewing the allotment of punishment as a confirmation of the social and political standing of the victim groups leads to a status competition between victim groups where the losers feel cheated by the lesser penalties their offenders receive.

-New York University Law School Professor James Jacobs and attorney Kimberly Potter (Southern Poverty Law Center, 1998, p. 31)

Hate crimes are different from many other crimes in at least three ways; they are intended to send a message to the victim and members of the victim's group; they generate an unusual sense of vulnerability in victims; and they tend to involve more violence than other crimes.

\section{- Testimony of Northeastern University Professor Jack McDevitt (Hate Crime Prevention Act of 1997, 1998)}

Over the past few decades, criminal law has placed a renewed focus on violent bigotry. Congress responded to Klan violence in the South during the civil rights era by enacting 18 U.S.C. $\S 245$ Federally Protected Rights in 1968. Congressional action was fueled by extensive hearings on Klan violence in 1965 and the unequivocal Supreme Court approval of two post-Civil War-era statutes, 18 U.S.C. $\S \S 241$ and 242 in 1966 . The 1968 statute prohibits interference with voting, obtaining government or federally funded benefits or services, accessing federal employment, or participation in a federal jury. Among other things, the law also punishes the interference with six other federally protected activities, but only when they are committed on the basis of race, color, religion, or national origin. Those protected activities include enrollment in public education, participation in state programs, obtaining private or state employment, participation in state and local jury service, interstate travel, and the benefits of various types of public accommodations. Despite the assertion by prosecutors and civil rights groups that the statute is too narrow, Congress has failed to pass bills since 1998 to amend 18 U.S.C. $§ 245$. The bills would add sexual orientation, gender, and disability to the protected characteristics and broadly expand the protected rights beyond the narrow list currently enumerated (Hate Crime Prevention Act of 1999). Even with all the limitations it places on federal prosecutors, 18 U.S.C. $\S 245$ remains the most widely used federal hate crime statute.

Today, hate crime laws actually reflect a broad category of offenses that cover prohibitions against cross burnings, desecration to houses of worship, as well as antimasking laws, penalty enhancements, and stand-alone civil rights or intimidation statutes. It is the last two statutes, the penalty enhancements and the stand-alone statutes, that are the most broadly applicable to the widest range of 


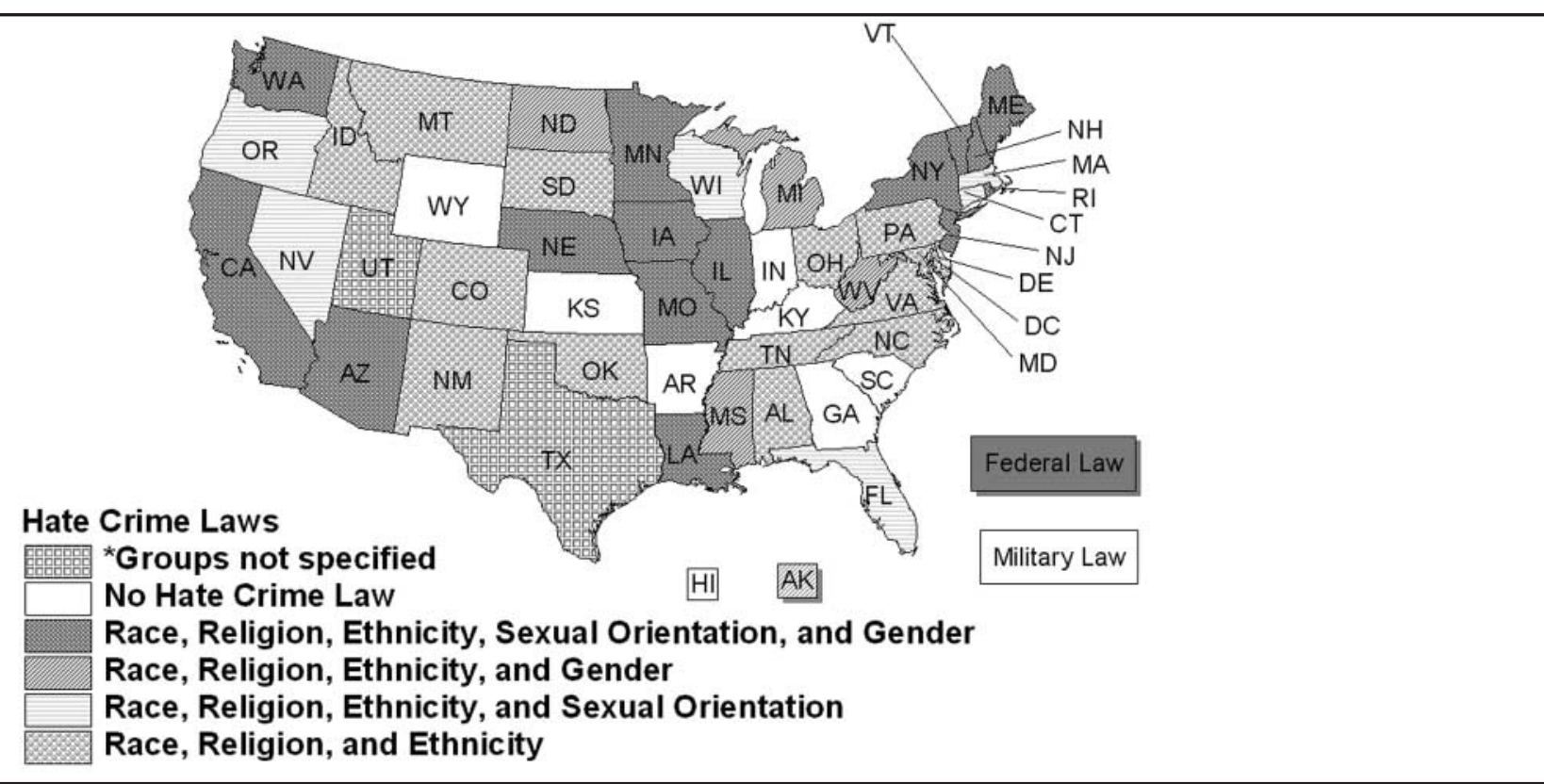

Figure 2: Hate Crime Laws in the United States

SOURCE: Center for the Study of Hate and Extremism, California State University, San Bernardino (fighthate.org); Anti-Defamation League (adl.org); and National Gay SOURCE: Center for the Study of Hate and Extremism, California State Univers
and Lesbian Task Force (ngltf.org). Map generated by Quyen Nhu Nguyen.

NOTE: Kentucky, Georgia, and Kansas enacted statutes since map was generated, and in spring 2001, Texas passed a statute that now specifies groups covered. 
TABLE 2: Reported Hate Crime in the United States by Year and Bias Motive

\begin{tabular}{lrrrrrrrr}
\hline & \multicolumn{8}{c}{ Year } \\
\cline { 2 - 9 } & 1992 & 1993 & 1994 & 1995 & 1996 & 1997 & 1998 & 1999 \\
\hline Total incidents $^{\text {a }}$ & 6,623 & 7,587 & 5,932 & 7,947 & 8,759 & 8,049 & 7,755 & 7,876 \\
Agencies participating $^{\text {a }}$ & 6,181 & 6,551 & 7,356 & 9,584 & 11,355 & 11,221 & 10,730 & 12,122 \\
Bias motivation & & & & & & & & \\
Race & 4,025 & 4,732 & 3,545 & 4,831 & 5,396 & 4,710 & 4,321 & $4,295(56 \%)$ \\
$\quad$ Anti-White & 1,342 & 1,471 & 1,010 & 1,226 & 1,106 & 993 & 792 & 781 \\
$\quad$ Anti-Black & 2,296 & 2,815 & 2,174 & 2,988 & 3,674 & 3,120 & 2,901 & 2,958 \\
$\quad$ Anti-Asian/Pacific & & & & & & & & \\
$\quad$ Islander & 217 & 258 & 211 & 355 & 355 & 347 & 293 & 298 \\
Ethnicity/National & & & & & & & & \\
origin & 669 & 697 & 638 & 814 & 940 & 836 & 754 & $829(11 \%)$ \\
$\quad$ Anti-Hispanic & 369 & 472 & 337 & 516 & 564 & 491 & 482 & 466 \\
Religion & 1,162 & 1,298 & 1,062 & 1,277 & 1,401 & 1,385 & 1,390 & $1,411(16.5 \%)$ \\
$\quad$ Anti-Jewish & 1,017 & 1,143 & 915 & 1,058 & 1,109 & 1,087 & 1,081 & 1,109 \\
$\quad$ Anti-Christian & 46 & 62 & 46 & 67 & 110 & 84 & 120 & 84 \\
$\quad$ Anti-Islamic & 15 & 13 & 17 & 29 & 27 & 28 & 21 & 32 \\
Sexual orientation & 767 & 860 & 685 & 1,019 & 1,016 & 1,102 & 1,260 & $1,317(16 \%)$ \\
$\quad$ Antigay/antilesbian & 760 & 830 & 664 & 984 & 991 & 1,081 & 1,231 & 1,288 \\
\hline
\end{tabular}

SOURCE: Federal Bureau of Investigation (1992, 1993, 1994, 1995, 1996, 1997, 1998, 1999). a. Year by year comparisons are discouraged because the number of agencies participating in the hate crime data collection program or reporting incidents varies from year to year. In addition, hate crimes are significantly underreported by victims and police.

b. Antibisexual is counted for total for sexual orientation but not for subtotal for antigay/antilesbian.

criminal conduct and the ones that are most commonly referred to as hate crime statutes.

This increased attention resulted in more serious treatment of misdemeanors and other crimes that would have otherwise garnered minimal sanctions. States such as California also enacted hate crime laws that increased the penalty for repeat hate crime offenders or those who commit hate crimes in groups. Other laws also allow victims of hate violence to obtain civil injunctions and monetary damages (Cal. Penal Code $\S \S 422.6,422.75$; Cal. Civ. Code $\S 52$ ). By 1991, 28 states had hate crime laws, increasing to 45 by the year 2001 (National Gay and Lesbian Task Force, 2001; National Institute Against Prejudice \& Violence, 1986, 1988).

At the federal level, four new pieces of legislation were introduced during this period. The first was the Hate Crime Statistics Act signed into law by President Bush in April 1990. The bill, initially introduced in 1985, is widely credited for adding the term hate crime to the American lexicon (Jacobs \& Potter, 1998). The act initially required the attorney general to collect data on crimes motivated by race, religion, sexual orientation, and ethnicity and was subsequently amended to include disability. The FBI was assigned the task of collecting the data and will continue to do so on a permanent basis. In 1998, 7,755 hate crime incidents were reported to the FBI. Out of 16,000 law enforcement agencies in 
the United States, 12,122 participated in the FBI's hate crime reporting program, but only 1,815 reported any incidents in 1999 .

In 1994, the Hate Crime Sentencing Enhancement Act was enacted. The statute, a penalty enhancement law, increases the sentence for underlying federal offenses by about $30 \%$ when the fact finder establishes beyond a reasonable doubt that the target is intentionally selected because of race, color, religion, national origin, ethnicity, gender, disability, or sexual orientation. The law's limitation is that it is only applicable to a relatively small number of substantive underlying federal offenses. In 1996, Congress enacted new legislation broadening coverage and increasing the penalties for church arsons. That legislation followed a series of well-publicized church arsons that disproportionately targeted African American institutions.

Initially introduced in 1998, the Hate Crime Prevention Act twice failed to come to a vote in the House of Representatives despite affirmative votes in the Senate as late as June 2000 under a new name. The bill would alter the main federal criminal civil rights statute, 18 U.S.C. $§ 245$, in two significant ways. First, the bill would extend federal legal protection on the basis of gender, disability, and sexual orientation - but only in cases involving interstate commerce. The interstate commerce qualification for those categories is necessary to provide federal jurisdiction under the commerce clause. The other statutory reform the bill provides is a broadening of the circumstances protected. Currently, 18 U.S.C. $\$ 245$ requires that prosecutors establish both that the victim was attacked because of his or her status and because of his or her exercise of a particular protected activity listed in the statute. The proposed statute would expand protections beyond the limited number of activities listed in the current statute.

\section{THE SUPREME COURT ADDRESSES HATEFUL OFFENDERS}

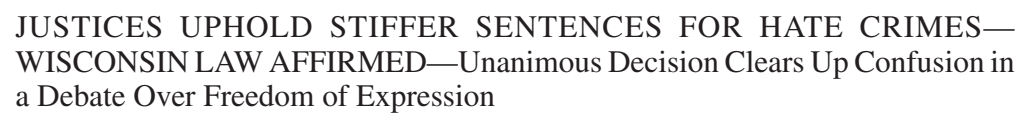

The Supreme Court set limits as to how hateful offenders may be punished for their crimes in several important cases. In Dawson v. Delaware (1992), the Supreme Court overturned a death sentence that was imposed in part on the basis of a convict's membership in a White supremacist group in a murder case where his racist beliefs and associations were not relevant to the crime. The Court found that a defendant's abstract beliefs were an impermissible basis to impose criminal punishment. Still, when relevant, the Court maintained that the " 
Constitution does not erect a per se barrier to the admission of one's beliefs and associations simply because those beliefs and associations are protected by the First Amendment" (p. 165).

In Barclay v. Florida (1983), 9 years prior, the Court ruled that a defendant's anti-White racial hatred and desire to start a race war were relevant in determining punishment in a racial homicide case. Although the government may not penalize abstract bigoted beliefs, it may introduce evidence of a defendant's constitutionally protected beliefs to show motive or to establish intentionality. The general rule requires that the evidence not only be relevant but its value be more probative than prejudicial (Federal Rules of Evidence, 2001, p. R. 403).

In R.A.V. v. St. Paul (1992), the Supreme Court was asked to rule on the constitutionality of a 1989 municipal hate speech ordinance used to prosecute a teenage skinhead for burning a cross in the yard of an African American family with several young children. The Court unanimously invalidated the statute, although the justices were deeply divided as to why. The statute read in relevant part,

Whoever places on public or private property a symbol, object, appellation, characterization, or graffiti, including but not limited to a burning cross or Nazi swastika, which one knows or has reasonable grounds to know arouses anger, alarm or resentment in others on the basis of race, color, creed, religion or gender, commits disorderly conduct and shall be guilty of a misdemeanor.

All nine justices agreed that the statute was impermissibly overbroad by punishing speech that merely evoked anger or resentment. The First Amendment has consistently been construed by the Court over recent decades as protecting extremely offensive speech and political discourse that fail to rise to the level of a threat, immediate incitement to criminality, or solicitation of a crime. The offensiveness of an idea is an impermissible basis for the government to punish expression (Texas v. Johnson, 1989).

Four of the justices supported the position that it was constitutional to punish expression whose severity went beyond merely offending someone. Because threats and so-called fighting words were traditionally held to be unprotected by the First Amendment, these justices maintained that it was permissible for the government to selectively punish bigoted speech within these categories on the basis of content.

The controlling opinion, authored by Associate Justice Antonin Scalia, held differently. These justices believed that even traditionally unprotected areas of speech must be punished without taking into account the content of the idea expressed. They held that punishing certain types of threatening cross burnings, such as those based on racial supremacy, but not others, such as those degrading the mentally ill, violated that principle. The R.A.V. decision invalidated those hate crime laws where the criminality hinged solely on the idea expressed. The ruling also had the additional effect of invalidating speech codes at public 
universities throughout the United States. Although the case did not overtly overturn the Beauharnais decision, the Court's rationale would not support the constitutionality of group libel statutes (R.A.V. v. St. Paul, 1992).

In 1996, the Court, without comment, refused to grant review of a challenge to a Florida state law that criminalized all hostile cross burnings on the property of another. That law, unlike St. Paul's ordinance, did not differentiate cross burnings on the basis of the hateful idea expressed (State v. T.B.D., 1995, 1996).

The issue of the overall validity of hate crime laws as a category was settled in 1993 in Wisconsin v. Mitchell, when the Court unanimously upheld the constitutionality of another type of hate crime statute-a penalty enhancement law. Specifically, the enhancement law at issue punished an offender's intentional selection of a victim or property based on the status characteristics of another person. The characteristics covered by Wisconsin's law included race, religion, color, national origin, and ancestry. Todd Mitchell was a 19-year-old African American Kenosha, Wisconsin, resident angered over a scene in the movie Mississippi Burning, where an African American child was beaten by White supremacists as he knelt to pray. Mitchell incited a crowd to viciously beat Gregory Riddick, a White 14-year-old passerby. He urged the mob to action by stating, "Do you all feel hyped up to move on some white people? You all want to fuck somebody up? There goes a white boy. Go get him."

Mitchell was convicted of aggravated battery-party to a crime and sentenced to 2 years for the underlying assault. He was assessed another 2-year term for intentionally selecting his victim on account of race, for a total of 4 years' incarceration out of a possible 7-year term.

In reversing the Wisconsin Supreme Court, the U.S. Supreme Court in an opinion by Chief Justice William Rehnquist cited three basic reasons for affirming the statute. First, whereas the government may not punish abstract beliefs, it can punish a vast array of depraved motives. The Court further found that penalty enhancement laws, unlike the statute at issue in R.A.V., did not prevent people from expressing their views or punish them for doing so. Lastly, the Court pointed to the severity of hate crimes, stating that they are "thought to be more likely to provoke retaliatory crimes, inflict distinct emotional harm on their victims and incite community unrest" (Wisconsin v. Mitchell, 1993).

Although a vast consortium ranging from police fraternal organizations to the American Civil Liberties Union (ACLU) filed briefs supporting the decision, not everyone was pleased with the outcome. Some prominent legal scholars contended that punishing discriminatory crimes more severely than other crimes was merely a subtly disguised legalistic end run to punish disfavored thoughts. New York University Law Professor James Jacobs and attorney Kimberly Potter criticized the Mitchell decision: "The very facts of that case present a defendant who is punished more severely, based on viewpoints" (Jacobs \& Potter, 1998). Conservative commentator George Will referred to hate crime laws as "moral pork barrel" and an "imprudent extension of identity politics" (Will, 1998). 
After the Mitchell decision, the intentional selection model, presumably because of its affirmation by the Court, became the preferred model for new hate crime legislation (see, for example, Hate Crime Sentencing Enhancement Act of 1994, § 280003 of the Violent Crime Control and Law Enforcement Act of 1994). Following a 1 -year hiatus that commenced with the R.A.V. decision, state legislatures once again enacted hate crime laws-using Wisconsin's model. State courts also upheld similar stand-alone laws modeled after traditional federal civil rights statutes. Laws like these, such as California Penal Code $\S 422.6$, do not require the charging of an additional crime. Stand-alone civil rights statutes generally punish the status-based interference with the civil rights of others through force or threat.

Although judicial decisions upheld the two most popular types of hate crime laws, important definitional issues remained unresolved. Courts and legislatures still had to address not only what groups to cover but precisely how much of a role the victim's racial, religious, or other status characteristic played in the offense. In In re M.S. (1995), the California Supreme Court addressed the latter issue by reviewing two of the state's primary hate crime statutes-one a standalone law and the other a penalty enhancer. Each law, enacted in 1987, punished the selection of a victim "because of" a status characteristic. The court ruled that "because of" meant "the prohibited bias must be a substantial factor in the commission of the crime" (In re M.S., 1995). To punish offenders who mistakenly attack victims from status groups that they had not intended for attack, legislatures included the language "actual or perceived" before listing status characteristics (Code of Ala. § 13A-5-13, 1997; D.C. Code § 22-4004, 1998 [civil remedies]; 720 ILCS 5/12-7.1, 1998; La. R.S. 14:107.2, 1998; Minn. Stat. § 609.595, 1997; Miss. Code Ann. § 99-19-301, 1997; Nev. Rev. Stat. Ann. § 193.1675, 1997; NY CP § 485.10; 13 Vermont S.A. § 1455, 1998; 14 Virgin Island C. § 707, 1998).

Some legislatures further refined their hate crime laws to also protect on the basis of sexual orientation, gender, and disability. "Moral" concerns over the inclusion of sexual orientation at the state and federal level by some conservative lawmakers have either caused bills to fail outright or to pass only with the offending category excluded. Still, by 2001, more than 20 states protected on the basis of gender, disability, and sexual orientation. In July 2000, New York passed an expansive hate crime bill after a decade in the legislature. New York's new law punishes crimes committed on the basis of race, color, national origin, ancestry, gender, religion, religious practice, age, disability, and sexual orientation (Hate Crimes Act of 2000, Art. 485).

Although carefully drafted hate crime laws remained intact, the U.S. Supreme Court limited government authority in two cases decided in the spring of 2000. In United States v. Morrison (2000), the Supreme Court invalidated a provision of the 1994 Violence Against Women Act that allowed victims of gender violence to sue their assailants civilly in federal court. A sharply divided Court split 5 to 4 in favor of throwing out a federal civil lawsuit by a former college student 
who alleged she was sexually assaulted by a football player. The majority held that sexual assault did not have enough of a nexus to interstate commerce to warrant federal jurisdiction (United States v. Morrison, 2000). Previously, until 1995, the Court approved of seemingly indirect connections to interstate commerce as a basis for upholding a variety of criminal and civil rights statutes (United States v. Lopez, 1995). Currently, federal prosecutors assert jurisdiction by relying on an expansive interpretation of the rights protected by 18 U.S.C. $\S 245$ when an attack takes place on a federally funded public street or sidewalk. That widely used prosecution theory is being reexamined in light of the Court's restrictive holding in Morrison. Shortly after the Morrison decision was handed down, the U.S. Court of Appeals for the Second Circuit in New York reviewed the federal civil rights conviction of a youth who killed a rabbinical student during rioting in Crown Heights, Brooklyn, in 1991 (S. Freeman, Anti-Defamation League, personal communication, July 7, 2000).

In June 2000, the Supreme Court struck down a New Jersey hate crime law in Apprendi v. New Jersey that allowed a judge, rather than a jury, to increase the sentence of a convicted defendant beyond the maximum enumerated in the criminal code for an underlying offense on a showing of racial bias by the preponderance of the evidence. The Court held 5 to 4 that when a factor affects a sentence as substantially as racial bias did in Apprendi, it must be established to a jury by a higher standard - beyond a reasonable doubt (Apprendi v. New Jersey, 2000). The impact of the decision in the area of hate crime law was limited because the overwhelming majority of hate crime statutes already meet the Court's heightened requirements.

After a series of anthrax cases via the mail greater attention was given to The Biological Weapons Act of 1989 which outlaws the possession, procurement, or manufacture of a "biological agent, toxin, or delivery system" for use as a weapon (18 USC 175).

\section{THE INTERNET}

\section{WHITE PRIDE WORLD WIDE WHITE NATIONALIST RESOURCE PAGE}

\footnotetext{
Stormfront is a resource for those courageous men and women fighting to preserve their White Western culture, ideals, and freedom of speech and association-a forum for planning strategies and forming political and social groups to ensure victory.
}

\section{—Current introductory page of Stormfront, which in 1995 became the} first "hate" site on the World Wide Web (www.stormfront.org)

The use of computer networks by White supremacists dates back to the early 1980s when West Virginia neo-Nazi publisher George Dietz established a computer bulletin board system (BBS) to post racist, anti-Semitic, and Holocaust 
denial material. These bulletin boards, accessible to those with a computer and a modem, were text postings arranged by titles that included "The Jew in Review," "The Holohoax," and "WVA Real Estate Bargains." These bulletin boards allowed space for additional comment and the downloading of files by interested users. Shortly thereafter, the Aryan Nations and White Aryan Resistance set up BBSs of their own to spread their ideology. The men behind each BBS, Louis Beam and Tom Metzger, are influential White supremacists whose ideology promotes random racist violence- a message well situated for the anonymous and far-reaching medium of computer networks. During the mid-1990s, antigovernment "patriot" groups added this technology to an array of communication media that included fax networks and short-wave radio broadcasts (Berlet, 2001).

It was in the spring of 1995 that computer programmer Don Black set up the first, and arguably most influential, hate Web site, Stormfront, from his Palm Beach, Florida, home. Black, a former Ku Klux Klansman and federal felon, was soon joined by other notorious extremists on the Web. Today, there are a vast array of bigots in cyberspace including the neo-Nazi National Alliance, Aryan Nations, White Aryan Resistance, World Church of the Creator, National Association for the Advancement of White People, various Klan factions, skinheads, Holocaust deniers, and hate rock promoters. It is estimated that there are about 500 hate Web sites on the Internet in addition to various chat rooms, e-mail services, and USENET posting locations. Out of those 500 hate sites, there are only a few dozen hub sites that update their content regularly and get a consistent stream of visitors (Perine, 2000).

Scholar Roger Eatwell cites the following reasons for the Internet's popularity among hatemongers: (a) the low cost, and potentially high-quality, presentation and distribution of information; (b) the ability to tailor messages to specific audiences who self-select the type of information they seek; (c) the ability to create an effective image of an ideological community; and (d) the ease of global distribution across jurisdictional boundaries (Griffin, 1997).

The Supreme Court addressed the regulation of controversial Internet content in Reno v. ACLU (1997), where certain restrictions on Internet messages were invalidated. The decision in Reno v. ACLU invalidated two parts of the Communications Decency Act dealing with sexual content. However, the decision had a significant impact on Internet regulation in general. In relevant parts, the act punished the "knowing" communication to minors of "obscene or indecent" messages. It also banned the knowing communication of messages to minors, or the display of messages in a way that minors could view them. The prohibited messages related to material that was "patently offensive as measured by contemporary community standards, sexual or excretory activities or organs."

The decision was a landmark for two reasons. First, the justices gave broad First Amendment protection to communications, dismissing government claims that the Internet should be restricted in the same manner as radio and television 
frequencies. The justices also dismissed the notion that the government can ban communications between adults on the grounds that minors might receive messages for which they are unfit.

The Court instead contended that the Internet was more like a public square than a television broadcast. In a series of cases dating back for decades, the Supreme Court has consistently held that speech in public forums such as streets and parks was subject to the most protection from content-based government regulation. The Internet thus was a forum where speech would be most protected:

Through the use of chat rooms, any person with a phone line can become a town crier with a voice that resonates farther than it could from any soapbox. Through the use of Web pages, mail explorers and newsgroups, the same individual can become a pamphleteer. As the District Court found, the content of the Internet is as "diverse as human thought." We agree ... that our cases provide no basis for qualifying the level of First Amendment scrutiny that should be applied to this medium.

The justices found that the Internet differed from television and radio broadcasts because there were unlimited available outlets, there was no precedent of governmental restrictions, and the recipient of the message actively searches for it with foreknowledge of its content. Based on this, the Court invoked the most stringent level of scrutiny to judge governmental restriction on expression over the Internet. The government may only restrict expression on the Internet when it is necessary to further an important governmental interest and is narrowly tailored to achieve that interest. The Court also attacked the statute's vagueness, particularly in its invocation of the words indecent and patently offensive.

Pursuant to the Court's ruling, offensive sites that spewed extremism remained constitutionally protected. The Court's ruling in Reno, however, did not extend protection to individuals who use the Internet as an instrumentality to commit conduct, such as threats, frauds, or criminal solicitation, that is unlawful irrespective of the context. In fact, Congress has authority under the Commerce Clause to enact new legislation or amend existing laws to more severely punish crimes where the Internet is involved.

White supremacist movements and foreign extremists alike have traditionally glorified both fraudulent activities and damaging infrastructure targets. The Internet, as a new infrastructure, enables extremists to do both. The advent of the Internet offers virtually unlimited opportunities for a new breed of younger, educated extremists to commit sophisticated fraudulent financial crimes, obtain confidential information, damage private and public computer systems, and efficiently communicate across international borders.

Whereas traditional laws can sometimes be used to prosecute computer crime, the federal government and all 50 states now have additional criminal legislation specifically addressing computer crime (18 Penn. Con. Stats. 3933; 18 U.S.C. $\S \S 1029,1030)$. Current cyber crime laws punish those who commit fraud by computer as well as those who use or damage data or hardware without 
authorization (Schmalleger, 1999). These new computer laws address such things as unauthorized computer tampering, fraud, trespass, and theft of services but do not create a new charge for cyber threats.

\section{CYBER THREATS}

Much of the media attention on the Internet and bigotry has focused on offensive Web sites. However, the medium has recently emerged as a vehicle for bigots to transmit illegal threats. The ease in which large numbers of victims can be threatened by mass e-mailings and the potential reach of Web site-posted threats warrant an examination of existing law. The character of certain Web site threats can be more complex than a solitary threat delivered in person or by letter. These threats can, and are often designed to, deliver not only a threat to an intended target but also a de facto solicitation to action to numerous other violence-prone extremists. It is this de facto solicitation component and the use of a wide-ranging instrumentality that warrant new legislation specifically addressing Web site threats.

Enhancing punishment for a crime because the offender used a particular instrumentality or new technology is nothing new in the criminal law. Existing law enhances punishment when a crime involves an aircraft, automatic weapons, or the use of a telecommunication system. Arguably, threats and other online crimes, undertaken by White supremacists and others, are substantively different owing to the ubiquitous nature of the Web. A threat divulging private information, broadcast over the Internet for example, not only can intimidate the target, but it can also be a criminal solicitation to others unknown-complete with valuable information that aids in the proposed crime's commission.

Currently, though, federal prosecutors have tried online bigoted criminals under existing law. On September 26, 1996, Richard Machado, using a university computer, sent a racist epithet-filled threat to about 60, mostly Asian, students at the University of California, Irvine, where he had flunked out, that warned, "I personally will make it my life career to find and kill everyone of you personally. OK?????? That's how determined I am. Get the fuck out, Mother Fucker (Asian Hater)" (United States v. Machado, 1998).

In February 1998, Machado became the first individual to be convicted in the United States of a so-called hate crime over the Internet. After a jury deadlock in his first trial, a subsequent jury convicted Machado of violating 18 U.S.C. $\$ 245$ for interfering with the students' right to attend a public college. Machado was sentenced to 1 year in prison (United States v. Machado, 1998).

Less than a month later, in March 1998, 67 Latino students and employees of California State University, Los Angeles; Massachusetts Institute of Technology; and other institutions received a threatening e-mail that read in part, "I hate your race. I want you all to die. will [sic] do kill all your people for me, wetback. ... I'm going to come down and kill your wetback, affirmative action ass.... I hate wetbacks!!! Kill all wetbacks!!!" (United States v. Quon, 1999). 
In June 1999, Kingman Quon, an Asian American California college student, received a 2-year sentence under 18 U.S.C. $\$ 245$ for sending those threatening e-mails. His probation bars him from using a computer or going online for a year once he is released from prison (United States v. Quon, 1999).

Online extremists face prosecution not only for violating traditional civil rights statutes but also from other statutes dealing with telecommunications. Under 47 U.S.C. $§ 223$, those who seek to threaten, annoy, or harass another through the use of a telecommunications device by making lewd, indecent, or anonymous contact face up to 2 years in prison. In addition, 18 U.S.C. $\S 875$ provides for up to 2 years' incarceration for threats communicated in interstate commerce that can include phone or computer lines.

In October 1998, a neo-Nazi hate site, Alpha HQ, run by longtime Philadelphia racist Ryan Wilson, became the first hate site to be removed by court order from the World Wide Web after the Pennsylvania Deputy Attorney General Trent Hargrove obtained a civil injunction. The attorney general's office contended that the site was in violation of state laws that prohibited harassment, terrorist threats, and ethnic intimidation. Wilson failed to appear in his own defense.

The site published threats against two Pennsylvania civil rights workers. One was Bonnie Jouhari, a fair housing and hate crime official from Reading. The site showed one photograph of Jouhari and another of her office exploding into flames. The site labeled her a "race traitor," a term commonly used by White supremacists to label an individual as a target of violence. The site, in referring to Jouhari, also said, "[She] has received warnings in the mail that she is a race traitor... Traitors like this should beware, for in our day, they will be hung from the neck from the nearest tree or lamp post" (Commonwealth $v$. Wilson et al., 1998). It also stated that Jouhari's fair housing work was injurious to society. After he was interviewed by the FBI, Wilson put up a disclaimer relating to violent acts, which a judge later held was ineffective (Commonwealth $v$. Wilson et al., 1998).

In July 2000, Department of Housing and Urban Development officials successfully sued Wilson for using his Web site and other media to violate the Fair Housing Act. The charge states he violated the act by threatening Jouhari and her daughter to prevent Jouhari from enforcing the act and living in her home. Jouhari's job obligated her to assist victims of housing discrimination in filing discrimination complaints pursuant to the act. Wilson, who did not contest the suit, was held liable for more than $\$ 1,100,000$ by an administrative law judge (Lichtblau, 2000).

In Planned Parenthood v. American Coalition of Life Activists (1999), a jury found a consortium of radical antiabortion organizations liable for \$107 million in a case arising out of wanted poster-type literature that was distributed both online and offline. The online literature included detailed personal information about abortion doctors along with a list of doctors that specifically referenced those who had been assaulted or murdered. Although the site did not explicitly 
direct readers to kill the doctors listed, it labeled them as murderers who needed to be brought to justice. After an injunction was issued, the Web site was taken offline but is sporadically available. On March 28, 2001, the United States Court of Appeals for the Ninth Circuit reversed the jury verdict and dissolved the lower court's injunction. The decision reaffirmed protection to "leaderless resistance" type Web activity. Judge Alex Kozinski declared, "Political speech may not be punished just because it makes it more likely that someone will be harmed at some unknown time in the future by an unrelated third party" (Planned Parenthood v. American Coalition of Life Activists, 2001).

In April 2000, two civil rights groups filed a lawsuit in France against the American Internet company Yahoo! for allowing Nazi paraphernalia to be auctioned on its Web site. French law prohibits the sale or exhibit of material that incites racism. A French court subsequently fined Yahoo! and ordered the company to find ways to restrict access by French citizens to the controversial site (Yahoo! v. La Ligue Contre Racism, 2001, p. 7565). Yahoo has since attempted to transfer the matter to a court in the United States.

Choice of law conflicts currently exist between the United States and other nations whose criminal laws punish hate speech-something protected under American law. Because the United States does not generally extradite people to other nations for offenses that are not crimes here, other nations will have a difficult task of asserting physical custody over vitriolic hatemongers who spread illegal rhetoric from a safe distance.

Beginning in the late 1970s a series of laws were passed that established standards for intelligence gathering on American residents and citizens who might be linked to foreign terrorists. Another type of statute, the Omnibus Diplomatic Security and Antiterrorism Act of 1986, in relevant part, expanded jurisdiction to cover terrorist acts and their attempts outside the United States where an American is the target. One year after the Oklahoma City Bombing the Antiterrorism and Effective Death Penalty Act of 1996 was enacted. Despite the protestations of various civil rights groups, the law imposed extensive restrictions on the number of appeals and the time allotted to pursue them in death penalty cases. The law also expanded the authority of the federal government to proscribe domestic fundraising by terrorist groups; to ban suspected terrorists from entering the United States and to expel those foreigners linked to terrorism.

A package of comprehensive legislation quickly passed by Congress in October 2001 in response to September's terrorist attacks. The least controversial portions increased enforcement and victim compensation funding. Other provisions enhanced penalties and removed the statute of limitation restrictions applied to various terrorism related offenses.

More controversial, however, are portions that streamlined and relaxed warrant, investigative, and detention requirements. The bill allows one federal court to have nationwide authority to approve roving wiretaps, phone record searches, and retrieval of electronic evidence. Roving wiretaps follow a particular person, 
allowing phone intercepts to proceed against multiple phones across numerous jurisdictions. (HR 2975) Attorney General Ashcroft promoted this measure over the protests of civil libertarians during Congressional testimony:

We need speed in identifying and tracking down terrorists. Time is of the essence. The ability of law enforcement to trace communications into jurisdictions without obtaining an additional court order can be the difference between life and death for American citizens. (Attorney General John Ashcroft, prepared remarks, Senate

Committee on the Judiciary, September 25, 2001)

\section{CONCLUSION}

Many of today's most influential extremists apparently have learned a legal lesson from the mistakes of their predecessors. After a series of disastrous criminal and civil judgments over the past two decades, modern American hatemongers have refined their message and their tactics. For a variety of reasons, including legal ones, today's extremists appear as content to inspire violence as their predecessors were to orchestrate it. In the past, groups such as the Klan believed they shared the goals if not the tactics of their overall community. Today, many extremists see their role changed from enforcers of a majoritarian status quo to warriors in a guerrilla insurgency. Technological innovations, such as the Internet, have allowed extremists to inexpensively spread their rhetoric and strategies to would-be terrorists, without the necessity and legal risks of maintaining a more direct relationship with them. Contemporary hate terror groups are no longer insulated from civil suits or prosecution by a sympathetic or insouciant legal system. Existing laws are being enforced with new vibrancy, whereas hate crime statutes and other new laws are being crafted to combat the evolving threat that bigots and other extremists pose. Still, in recent decades the Supreme Court has carved an important niche that protects the rights of extremists to peaceably associate and promote their views, whether it be in cyberspace, handbills, or the town square.

\section{REFERENCES}

Abrams v. United States, 250 U.S. 616 (1919).

Alien and Sedition Acts of 1798, 1 Stat. 596 (1798).

Apprendi v. New Jersey, -U.S.- (2000).

Antiterrorism Act of 2001 (H.R. 2975 107th Cong.).

Antiterrorism and Effective Death Penalty Act of 1996 [PL 104-132].

Associated Press. (1996, August 22). American neo-Nazi gets four years in Germany [Wire, Berlin, Germany].

Associated Press. (2001, October 16) Attack Briefs [Wire, Fort Pierce, Fl.]

Barclay v. Florida, 463 U.S. 939 (1983).

Barron v. the Mayor and City Council of Baltimore, 7 Pet. 243 (1833).

Beauharnais v. Illinois, 343 U.S. 250 (1952). 
Berlet, C. (2001, April 28). When hate went online. Paper presented at the Northeast Sociological Association, Spring Conference, Sacred Heart University, Fairfield, CT.

Biskupic, J., \& Witt, E. (1997). The Supreme Court at work (2nd ed.). Washington, DC: Congressional Quarterly.

Biological Weapons Act. (1989). 18 U.S.C. 175.

Black's law dictionary (5th ed.). (1983). St. Paul, MN: West.

Brandenburg v. Ohio, 935 U.S. 444 (1969).

Bryant v. Zimmerman, 278 U.S 63 (1928).

Bullard, S. (Ed.). (1991). Special report: The Ku Klux Klan: A history of racism and violence (4th ed.). Montgomery, AL: Southern Poverty Law Center.

Cantwell v. Connecticut, 310 U.S. 296 (1940).

Chaplinsky v. New Hampshire, 315 U.S. 568 (1942).

Cohen v. California, 403 U.S. 15 (1971).

Commonwealth v. Wilson et al., Pa., (C.P. Berks County, October 21, 1998).

Dawson v. Delaware, 503 U.S. 159 (1992).

Dennis v. United States, 341 U.S. 494 (1951).

Edwards, L., \& Edwards, J. (1998). Tort law for legal assistants. St. Paul, MN: West.

Federal Bureau of Investigation. (1992). Hate crime statistics. Washington, DC: U.S. Government Printing Office.

Federal Bureau of Investigation. (1993). Hate crime statistics. Washington, DC: U.S. Government Printing Office.

Federal Bureau of Investigation. (1994). Hate crime statistics. Washington, DC: U.S. Government Printing Office.

Federal Bureau of Investigation. (1995). Hate crime statistics. Washington, DC: U.S. Government Printing Office.

Federal Bureau of Investigation. (1996). Hate crime statistics. Washington, DC: U.S. Government Printing Office.

Federal Bureau of Investigation. (1997). Hate crime statistics. Washington, DC: U.S. Government Printing Office.

Federal Bureau of Investigation. (1998). Hate crime statistics. Washington, DC: U.S. Government Printing Office.

Federal Bureau of Investigation. (1999). Hate crime statistics. Washington, DC: U.S. Government Printing Office.

Federal rules of evidence. (2001). Washington, DC: U.S. Government Printing Office.

Feiner v. New York, 340 U.S. 290 (1951).

Gitlow v. New York, 268 U.S. 652 (1925).

Greenhouse, L. (1993, June 12). Justices uphold stiffer sentences for hate crimes. The New York Times, p. 1.

Griffin, R. (1997). Caught in its own net: Post-war fascism outside Europe [Online]. Available: www.brookes.ac.uk/schools/humanities/Roger/2457/FASOUT.htm

Gunther, G. (1990, Spring). Good speech, bad speech: A debate. Stanford Lawyer, 24, 6-9, 40-41.

Halpern, T., \& Levin, B. (1996). The limits of dissent: The constitutional status of armed civilian militias. Amherst, MA: Aletheia Press.

Hate Crime Prevention Act of 1997: Testimony before the House Judiciary Committee (1998, July 22) (testimony of Jack McDevitt).

Hate Crime Prevention Act of 1999, S. 622, 106th Cong. (1999).

Hate Crime Sentencing Enhancement Act of 1994, § 280003 of the Violent Crime Control and Law Enforcement Act of 1994, Pub. L. No. 103-322, 108 Stat. 1796, 2096 (1994).

Hate Crime Statistics Act of 1990, 28 U.S.C. $\$ 534$ (1990).

Hate Crimes Act of 2000, NY Crim. Proc. L., § 485.10 (2000).

Herndon v. Lowry, 301 U.S. 242 (1937).

In re M.S., 10 Cal. 4th 698 (1995). 
Irving v. Penguin and Lipstadt, Queens Bench (April 11, 2000).

Jacobs, J., \& Potter, K. (1998). Hate crimes: Criminal law \& identity politics. New York: Oxford University Press.

Jacoby, J. (1999, November 4) Betraying the victims of terror. The Boston Globe, editorial page. Jew Watch. (1992). Jewish murder plan against gentile humanity exposed (Issue 16). Victoria, TX: Der Freikorpsmann Presse.

Kessler, J., \& Rosenberg, D. (2000). Combatting extremism in cyberspace. New York: Anti-Defamation League.

Levin, B. (1999). Hate crime: Worse by definition. Journal of contemporary criminal justice, 15, 6-21.

Lichtblau, E. (2000, July 21). Neo-Nazi must pay \$1.1 million to fair housing activist. Los Angeles Times, p. A19.

Macdonald, A. (1978). The Turner diaries. Hillsboro, WV: National Vanguard Books.

Marbury v. Madison, 1 Cr. 137 (1803).

Metromedia, Inc. v. San Diego, 453 U.S. 490 (1981).

Mill, J. (1983). On liberty. New York: Penguin. (Original work published 1859)

NAACP v. Alabama ex rel. Patterson, 387 U.S. 449 (1958).

NAACP v. Button, 371 U.S. 415 (1963).

National Gay and Lesbian Task Force. (2001). Information received from http://www.ngltf.org/ downloads/hatemap0601.gif

National Institute Against Prejudice \& Violence. (1986). Striking back at bigotry. Baltimore:

National Institute Against Prejudice \& Violence. (1988). Striking back at bigotry (Supp.). Baltimore: Author.

Nazi America: A secret history [Television broadcast]. (2000). New York: History Channel.

New York Times v. Sullivan, 376 U.S. 254 (1964).

Noto v. United States, 367 U.S. 290 (1961).

N.O.W. v. Scheidler, 510 U.S. 249 (1994).

Omnibus Diplomatic Security and Antiterrorism Act of 1986 [PL 99-399]

Perine, K. (2000, July 25). The trouble with regulating hatred online [Online]. Available: www.cgi.cnn.com/2000/TECH/computing/07/25/ regulating.hatred.idg/

Person v. Miller, 854 F.2d 656 (4th Cir. 1988).

Pierce, W. (1995). Hate speech. Free speech 1995 [Online]. Available: www.natvan.org

Planned Parenthood v. American Coalition of Life Activists, 23 F. Supp.2d 1182 (9th Cir. 1999).

Presser v. Illinois, 116 U.S. 252 (1886).

Public Order Act 1986, United Kingdom (1), §§ 17 et. seq. (1986).

Quilici v. Village of Morton Grove, 695 F.2d 261 (7th Cir. 1982), cert. denied, 464 U.S. 863 (1983).

R.A.V. v. St. Paul, 505 U.S. 377 (1992).

Reno v. ACLU, 521 U.S. 844 (1997).

Ridgeway, J. (1995). Blood in the face. New York: Thunder's Mouth Press.

Rowan v. Post Office Dept., 397 U.S. 728 (1970).

Schenck v. United States, 249 U.S. 47 (1919).

Schmalleger, F. (1999). Criminal law today: An introduction with capstone cases. Englewood Cliffs, NJ: Prentice Hall.

Southern Poverty Law Center. (1998, Summer). Klanwatch intelligence report (Issue No. 91). Montgomery, AL: Author.

Southern Poverty Law Center. (1999, Summer). Klanwatch intelligence report (Issue No. 95). Montgomery, AL: Author.

Southern Poverty Law Center. (2000, Winter). Intelligence report (Issue No. 97). Montgomery, AL: Author.

State v. Klapprott, 22 A.2d 877 (1941).

State v. T.B.D., 656 So.2d 479 (Fla. 1995), cert. denied, 116 S.Ct. 1014 (1996).

Taking aim. (1994, November). Militia of Montana Newsletter, 1,8. 
Terminiello v. Chicago, 337 U.S. 1 (1949).

Texas v. Johnson, 491 U.S. 397 (1989).

Thompson, B., \& Weller, W. (1998). Under the hood: Unmasking the modern Ku Klux Klan. Northmanchester, ID: DeWitt.

Tribe, L. (1988). American constitutional law. Westbury, NY: Foundation Press.

United States v. Emerson, No. 6:98-CR-103-C (W.D. Tex. 1999).

United States v. Emerson, 2001 U.S. App. Lexis 22386 (Fifth Circuit, October 16, 2001)

United States v. Fortier, No. 98-6249 (W.D. OK. 1998).

United States v. Lopez, 514 U.S. 549 (1995).

United States v. Machado, No. 96-142 (C.D. CA. 1998).

United States v. McVeigh, No. 97-CR-68 (C.D. CO. 1997).

United States v. Morrison, -U.S.- (2000).

United States v. O'Brien, 391 U.S. 367 (1968).

United States v. Quon, No. 99-76 (C.D. CA. 1999).

Van Alstyne, W. (1984). Interpretations of the First Amendment. Durham, NC: Duke University Press.

Vietnamese Fishermen's Association v. Knights of the Ku Klux Klan, F. Supp. 198 (S.d. Tex. 1982). Walker, S. (1994). Hate speech: The history of an American controversy. Lincoln, NE: Bison Books. Watts v. United States, 394 U.S. 705 (1969).

Whitney v. California, 247 U.S. 357 (1927).

Widmar v. Vincent, 454 U.S. 263 (1981)

Will, G. (1998, October 15). No need to broaden federal hate crime law. Asbury Park Press, p. a13.

Wisconsin v. Mitchell, 508 U.S. 476 (1993).

Yahoo! v. La Ligue Contre Racism, 2001 U.S. Dist. LEXIS (2001).

Yates v. United States, 354 U.S. 298 (1957).

Zawitz, M. (Ed.). (1988). Report to the nation on crime and justice (2nd ed.). Washington, DC: Bureau of Justice Statistics. 